UNIVERSIDADE DE SÃO PAULO

ESCOLA DE ENGENHARIA DE SÃO CARLOS

DEPARTAMENTO DE ENGENHARIA DE ESTRUTURAS

JOSÉ ANCHIÊTA DAMASCENO FERNANDES NETO

Estudo experimental do comportamento de elementos de alvenaria estrutural com blocos cerâmicos em situação de incêndio 



\section{Estudo experimental do comportamento de elementos de alvenaria estrutural com blocos cerâmicos em situação de incêndio}

\section{VERSÃO CORRIGIDA}

A versão original encontra-se na Escola de Engenharia de São Carlos

Dissertação apresentada ao Programa de PósGraduação em Engenharia Civil (Engenharia de Estruturas) da Escola de Engenharia de São Carlos da Universidade de São Paulo para obtenção do título de Mestre em Ciências.

Área de Concentração: Estruturas

Orientador: Prof. Assoc. Márcio Roberto Silva Corrêa 


\section{AUTORIZO A REPRODUÇÃO TOTAL OU PARCIAL DESTE TRABALHO, POR QUALQUER MEIO CONVENCIONAL OU ELETRÔNICO, PARA FINS DE ESTUDO E PESQUISA, DESDE QUE CITADA A FONTE.}

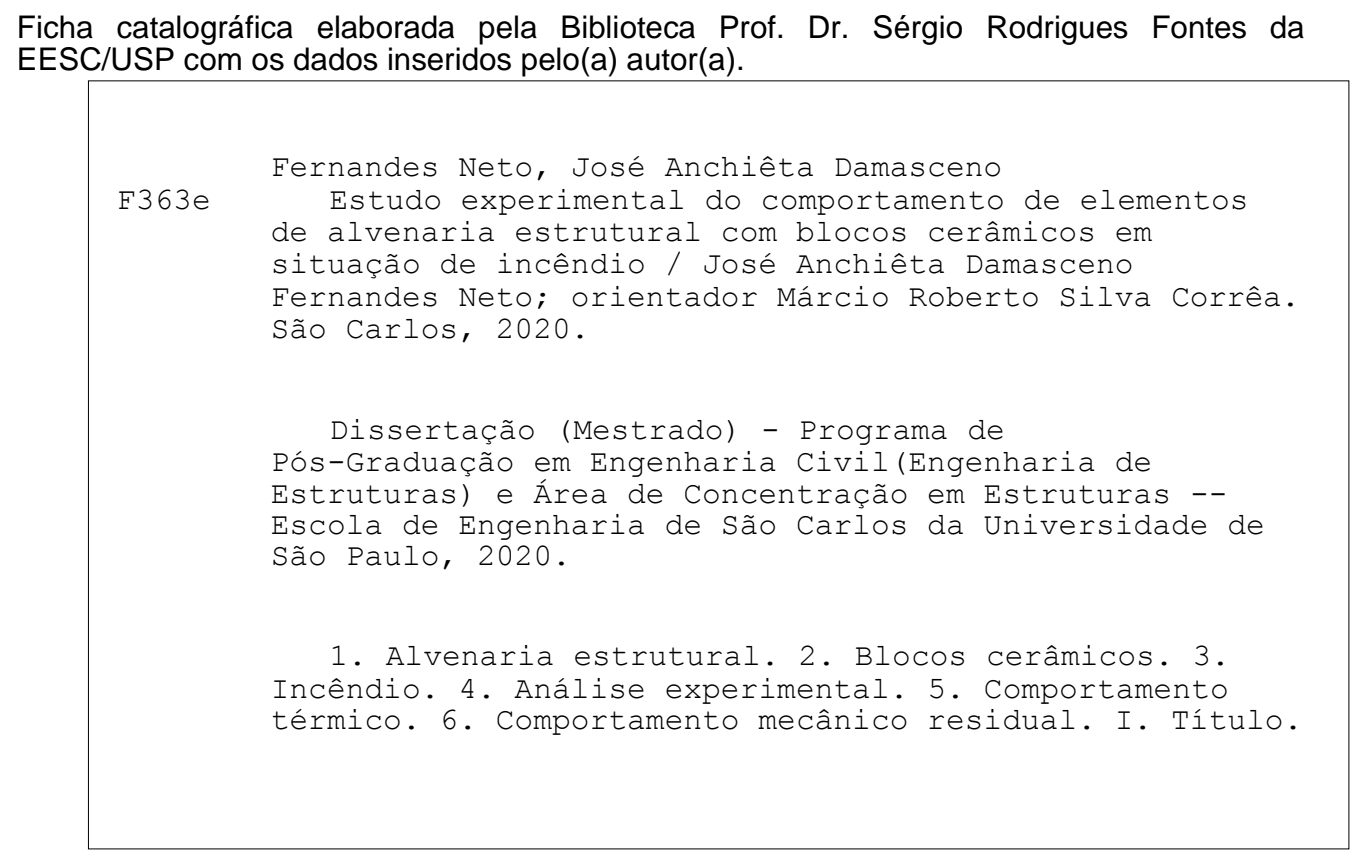




\section{FOLHA DE JULGAMENTO}

Candidato: Bacharel JOSÉ ANCHIÊTA DAMASCENO FERNANDES NETO.

Título da dissertação: "Estudo experimental do comportamento de elementos de alvenaria estrutural com blocos cerâmicos em situação de incêndio".

Data da defesa: 07/05/2020

Comissão Julgadora

Resultado

Prof. Associado Marcio Roberto Silva Corrêa

APROVADO

(Orientador)

(Escola de Engenharia de São Carlos - EESC/USP)

Prof. Associado Armando Lopes Moreno Junior

APROVA.dO

(Universidade Estadual de Campinas/UNICAMP)

Prof. Associado Gihad Mohamad

ARROVADO

(Universidade Federal de Santa Maria/UFSM)

Coordenador do Programa de Pós-Graduação em Engenharia Civil (Engenharia de Estruturas):

Prof. Associado Vladimir Guilherme Haach

Presidente da Comissão de Pós-Graduação:

Prof. Titular Murilo Araujo Romero 

Aos meus pais,

dedico este trabalho, com eterna gratidão. 



\section{AGRADECIMENTOS}

Agradeço primeiramente a Deus, fonte de inspiração e perseverança nos momentos mais difíceis, pela serenidade, sabedoria e por sempre iluminar o meu caminho com fé e esperança.

À minha família, em especial aos meus Pais, Maria do Perpétuo e Raimundo Nonato, e ao meu irmão João, que apesar da distância sempre se mantiveram presentes, concedendo apoio, carinho e motivação durante o trabalho.

Ao Professor Márcio Corrêa, pela orientação desta pesquisa, paciência, prontidão e, sobretudo pelas sugestões, críticas e conhecimentos compartilhados.

Aos Professores Vladimir Haach e Jorge Munaiar pelas discussões e contribuições técnicas dadas a este trabalho.

Aos amigos do Departamento de Engenharia de Estruturas, pela amizade, sugestões ao trabalho, e pela companhia nos tantos momentos de descontração e aflição que passamos durante esse período.

Ao corpo técnico do Laboratório de Estruturas Prof. Dante Martinelli, pelas sugestões e suporte na realização dos ensaios experimentais.

Aos demais professores e funcionários do Departamento de Engenharia de Estruturas, que de maneira direta ou indireta contribuíram para o desenvolvimento deste trabalho.

À Escola de Engenharia de São Carlos, em especial ao Departamento de Engenharia de Estruturas, pela disponibilização de infraestrutura, suporte técnico e contribuições de cunho pessoal e profissional ao longo desses anos.

À Cerâmica Palma de Ouro pelo fornecimento de dados técnicos e doação de materiais estritamente necessários para realização deste trabalho.

À Fundação Nacional da Cerâmica (FUNDACER) e à Associação Nacional da Indústria Cerâmica (ANICER) pelo apoio, suporte e financiamento desta pesquisa.

Ao Conselho Nacional de Desenvolvimento Científico e Tecnológico (CNPQ) pela bolsa de mestrado concedida. 



\section{RESUMO}

FERNANDES NETO, J. A. D. Estudo experimental do comportamento de elementos de alvenaria estrutural com blocos cerâmicos em situação de incêndio. 2020. 179p. Dissertação (Mestrado em Ciências - Engenharia Civil (Engenharia de Estruturas)) - Escola de Engenharia de São Carlos, Universidade de São Paulo, São Carlos, 2020.

Os sistemas em alvenaria estrutural são largamente utilizados em todo o país, sobretudo nos últimos anos com a aplicação de vantagens técnicas e econômicas atreladas ao sistema. Apesar da ampla utilização dos elementos estruturais em alvenaria, o comportamento destes elementos quando submetidos à ação do incêndio ainda é pouco abordado no país, que atualmente não conta com uma normatização e procedimentos para o dimensionamento de edificações de alvenaria estrutural em situação de incêndio. Diante disso, este trabalho tem como objetivo principal avaliar o comportamento térmico e mecânico residual de elementos de alvenaria estrutural com blocos cerâmicos quando sujeitos à situação de incêndio. Para tal, realizou-se um extenso programa experimental no qual argamassas, blocos, prismas e pequenas paredes de alvenaria estrutural foram caracterizados em temperatura ambiente, e posteriormente submetidos a ensaios de simulação de incêndio-padrão seguindo a curva proposta pela ISO 834-1:1999. Finalmente, todos os componentes e elementos estruturais foram avaliados quanto ao comportamento mecânico residual. A partir das simulações de incêndio-padrão, observou-se que os elementos estruturais apresentaram elevada danificação após a ação do fogo. Além disso, elementos constituídos por blocos de paredes maciças apresentaram maior grau de compartimentação e isolamento térmico 27\% superior em relação aos elementos com blocos de paredes vazadas. No mesmo contexto, a adição dos revestimentos em argamassas de cimento e gesso elevou em $103 \%$ e $54 \%$, respectivamente, o tempo necessário para perda do critério de isolamento térmico. Quanto ao comportamento mecânico residual, notou-se que os blocos cerâmicos apresentaram resistência residual de $100,8 \%$ e $91,6 \%$ para as unidades com paredes vazadas e maciças, respectivamente. As pequenas paredes compartimentadas com blocos de paredes maciças manifestaram resistência residual quatro vezes superior em relação aos mesmos elementos com blocos de paredes vazadas, que por sua vez apresentaram $34,1 \%$ e $40 \%$ de resistência residual quando revestidos com argamassas de cimento e gesso, respectivamente.

Palavras-chave: Alvenaria estrutural. Blocos cerâmicos. Incêndio. Análise experimental. Comportamento térmico. Comportamento mecânico residual. 



\begin{abstract}
FERNANDES NETO, J. A. D. Experimental study of the behavior of structural masonry elements with hollow clay blocks under fire situation. 2020. 179p. Dissertation (M. Sc. in Civil Engineering (Structural Engineering)) - São Carlos School of Engineering, University of São Paulo, São Carlos, 2020.

Structural masonry systems are widely used throughout the country, especially in recent years with the application of technical and economic advantages linked to the system. Despite the large use of structural elements in masonry, the behaviour of these elements when subjected to fire action is little addressed in the country, which currently doesn't have standards and procedures for the design of structural masonry buildings in a fire situation. Therefore, this research has as main objective the evaluation of the thermal and mechanical behaviour of structural masonry elements with clay hollow blocks under fire situation. Thus, an extensive experimental program was carried to characterize mortars, blocks, prisms and wallets of structural masonry at room temperature, and subsequently the elements were submitted to fire simulation tests following the curve standardized by ISO 834-1:1999. Finally, all components and structural elements were evaluated for residual mechanical behaviour. From the fire simulations, it was observed that the structural elements presented high damage after the fire. Moreover, elements composed of solid shell hollow blocks showed a higher compartmentalization and thermal insulation $27 \%$ better compared to elements with double shell hollow blocks. In this context, the addition of coatings in cement and gypsum mortars increased by $103 \%$ and $54 \%$, respectively, the time required to lose the thermal insulation criterion. About the residual mechanical behaviour, it was noted that the clay hollow blocks presented residual strength of $100.8 \%$ and $91.6 \%$ for double shell hollow blocks and solid shell hollow blocks, respectively. The masonry wallets compartmentalized with solid shell hollow blocks showed residual strength four times higher than the elements with double shell hollow blocks, which in turn exhibited $34.1 \%$ and $40 \%$ residual strength when coated with cement and gypsum mortars, respectively.
\end{abstract}

Keywords: Structural masonry. Clay hollow blocks. Fire. Experimental analysis. Thermal behaviour. Residual mechanical behaviour. 



\section{LISTA DE FIGURAS}

Figura 2.1 - Edifícios em alvenaria estrutural com blocos de concreto e cerâmicos ............... 33

Figura 2.2 - Blocos cerâmicos estruturais com parede vazada, maciça e alveolar .................. 35

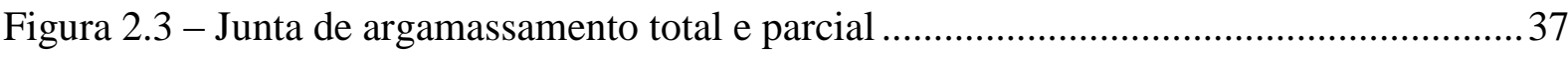

Figura 2.4 - Grande incêndio de Roma em 64 d.C .............................................................. 41

Figura 2.5 - Distribuição dos incêndios no mundo em 2017 de acordo com o tipo ................ 42

Figura 2.6 - Incêndio nos edifícios Andraus e Joelma na cidade de São Paulo........................ 43

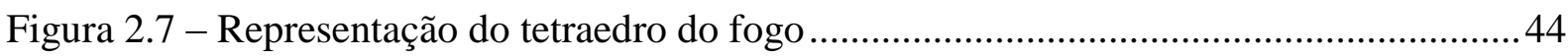

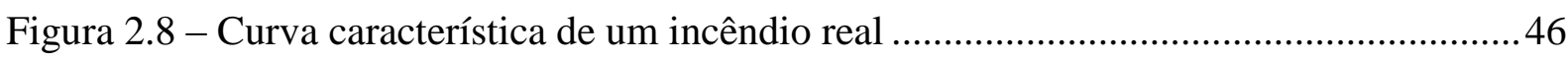

Figura 2.9 - Curva característica de um incêndio natural ................................................... 47

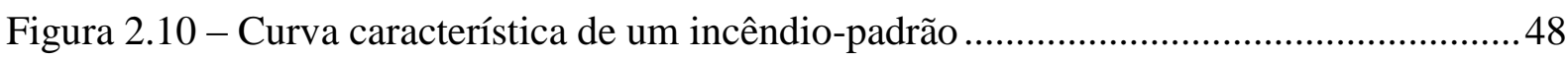

Figura 2.11 - Curvas padronizadas de incêndio-padrão .........................................................50

Figura 2.12 - Transferência de calor e distribuição de temperatura não linear em bloco de

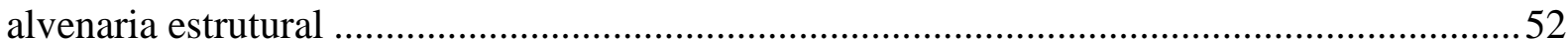

Figura 2.13 - Conceito de Tempo requerido de resistência ao fogo (TRRF) .........................53

Figura 2.14 - Configuração dos corpos de prova submetidos à elevação de temperatura ........56

Figura 2.15 - Variação de temperatura na face não exposta ao fogo ......................................57

Figura 2.16 - Vista geral do forno e da pequena parede antes do ensaio.................................58

Figura 2.17 - Análise térmica aos 240 minutos dos painéis (a) sem preenchimento, (b) grauteados, (c) preenchidos com areia e (d) superfície exposta após o ensaio

Figura 2.18 - Termografia em blocos cerâmicos estruturais com espessura de $14 \mathrm{~cm}$ e $19 \mathrm{~cm}$

Figura 2.19 - Lascamento em parede de alvenaria estrutural com blocos cerâmicos .............. 62

Figura 2.20 - Blocos cerâmicos de alvenaria estrutural utilizados no estudo ........................... 64

Figura 2.21 - Fissuração nos diferentes tipos de blocos .......................................................65

Figura 2.22 - Subpartes da estrutura considerada para avaliação numérica ............................66

Figura 2.23 - Deformação das paredes com incêndio em cenários distintos ............................. 67

Figura 2.24 - Pequena parede de alvenaria estrutural sob teste de compressão antes da elevação de temperatura

Figura 2.25 - Fenômeno do lascamento em paredes de alvenaria sem carregamento e carregadas

Figura 2.26 - Componentes de tensão nos septos de blocos de alvenaria sob ação do fogo ... 70

Figura 3.1 - Blocos cerâmicos com paredes vazadas e paredes maciças 
Figura 3.2 - Determinação das dimensões efetivas das unidades de paredes vazadas e maciças

Figura 3.3 - Determinação da espessura dos septos e das paredes externas ........................... 76

Figura 3.4 - Determinação do desvio em relação ao esquadro e planeza das faces ................. 76

Figura 3.5 - Determinação das massas aparente e saturada das unidades cerâmicas .............. 78

Figura 3.6 - Procedimento de secagem e saturação dos blocos cerâmicos ............................. 79

Figura 3.7 - Ensaio de resistência à compressão em bloco cerâmico...................................... 80

Figura 3.8 - Diagrama tensão x deformação dos blocos com paredes (a) vazadas e (b) maciças

Figura 3.9 - Ensaio de resistência à compressão em meio-bloco cerâmico ............................ 82

Figura 3.10 - Diagramas tensão x deformação dos meio-blocos com paredes (a) vazadas e (b)

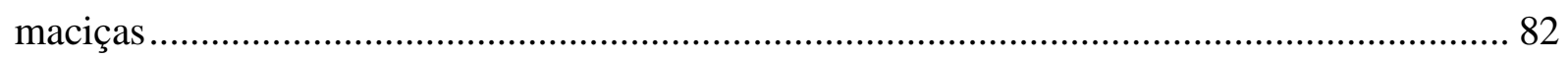

Figura 3.11 - Modo de ruptura das unidades cerâmicas .................................................... 83

Figura 3.12 - Ensaio de tração indireta em blocos com paredes (a) vazadas e (b) maciças .... 84

Figura 3.13 - Diagramas tensão x deformação dos blocos com paredes (a) vazadas e (b)

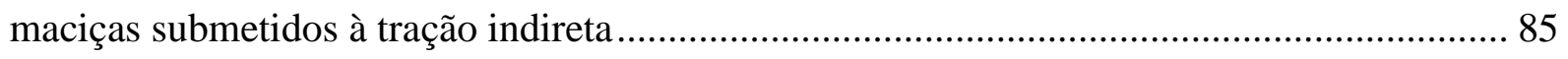

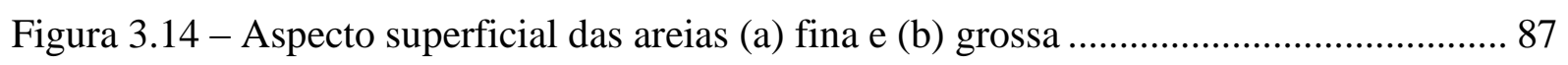

Figura 3.15 - Distribuição granulométrica das areias........................................................ 88

Figura 3.16 - Procedimento para obtenção do índice de consistência da argamassa ............... 89

Figura 3.17 - Ensaio de resistência à compressão da argamassa de assentamento ................. 90

Figura 3.18 - Diagrama tensão x deformação da argamassa de assentamento........................ 91

Figura 3.19 - Consistência das argamassas de gesso com composição (a) 1:0,5, a/g = 0,45, areia grossa (b) $1: 1, \mathrm{a} / \mathrm{g}=0,75$, areia fina e (c) $1: 2, \mathrm{a} / \mathrm{g}=1,10$, areia grossa ........................ 93

Figura 3.20 - Procedimento para determinação do tempo de pega dos revestimentos em gesso

Figura 3.21 -Variação do tempo de pega dos revestimentos em gesso de acordo com a

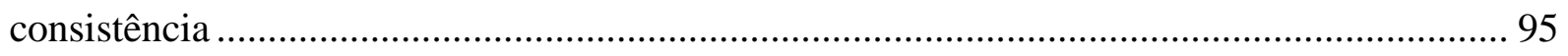

Figura 3.22 - Ensaios de flexão e compressão em argamassas para revestimento................... 96

Figura 3.23 - Ensaio de aderência em argamassas para revestimento................................... 97

Figura 3.24 - Influência da relação água/gesso nas resistências à (a) compressão (b) flexão e

(c) aderência das argamassas de gesso para revestimento 99

Figura 3.25 - Superfície de ruptura à flexão da (a) pasta, a/g = 0,45 (b) Argamassa 1:1, a/g = 0,55, areia fina e (c) Argamassa 1:2, a/g = 0,70, areia grossa ......................................... 100

Figura 3.26 - Relação entre a resistência à compressão e flexão para argamassas de gesso 100 
Figura 3.27 - Execução dos prismas e pequenas paredes de alvenaria estrutural...................101

Figura 3.28 - Ensaio de resistência à compressão em (a) prisma e (b) pequena parede ......... 102 Figura 3.29 - Diagramas tensão x deformação dos prismas com blocos de paredes (a) vazadas e (b) maciças 103

Figura 3.30 - Diagramas tensão x deformação das pequenas paredes com blocos de paredes (a) vazadas e (b) maciças.... 104

Figura 3.31 - Modo de ruptura dos prismas 105

Figura 3.32 - Modo de ruptura das pequenas paredes 105

Figura 4.1 - Forno horizontal a gás 109

Figura 4.2 - Execução do revestimento nos elementos de alvenaria 111

Figura 4.3 - Organização da fornada I 113

Figura 4.4 - Disposição dos corpos de prova na fornada I 114

Figura 4.5 - Pequenas paredes compartimentadas ensaiadas em trio 114

Figura 4.6 - Organização da fornada II . 116

Figura 4.7 - Disposição dos corpos de prova na fornada II 116

Figura 4.8 - Prismas cerâmicos revestidos com (a) argamassa de cimento (b) pasta de gesso e argamassas de gesso (c) 1:0,5 (d) 1:1 e (e) 1:2 após situação de incêndio 117

Figura 4.9 - Organização da fornada III. 119

Figura 4.10 - Disposição dos corpos de prova na fornada III 119

Figura 4.11 - Mistura de argila utilizada para auxílio na instrumentação 121

Figura 4.12 - Microfissura e interface devido à presença dos resíduos cerâmicos 121

Figura 4.13 - Formação de vazio devido ao desprendimento de resíduo cerâmico 122

Figura 4.14 - Disposição dos cabos termopares em elementos de alvenaria. 122

Figura 4.15 - Instrumentação dos blocos com paredes (a) vazadas e (b) maciças 123

Figura 4.16 - Instrumentação dos prismas com blocos de paredes (a) vazadas e (b) maciças

Figura 4.17 - Instrumentação das pequenas paredes isoladas com blocos de paredes (a) vazadas e (b) maciças

Figura 4.18 - Instrumentação das pequenas paredes compartimentadas sem revestimento com blocos de paredes (a) vazadas e (b) maciças

Figura 4.19 - Instrumentação das pequenas paredes compartimentadas com blocos de paredes vazadas revestidas com argamassa de (a) cimento e (b) gesso 1:2 125

Figura 4.20 - Instrumentação dos revestimentos em gesso (a) pasta e (b) argamassa 1:2 .... 125 Figura 4.21 - Evolução da temperatura média do forno durante as fornadas 
Figura 4.22 - Elevação de temperatura nos blocos com paredes (a) vazadas e (b) maciças . 127 Figura 4.23 - Elevação de temperatura nos prismas de alvenaria com blocos de paredes (a) vazadas e (b) maciças.

Figura 4.24 - Elevação de temperatura nas pequenas paredes isoladas com blocos de paredes (a) vazadas e (b) maciças 129

Figura 4.25 - Elevação de temperatura nas pequenas paredes compartimentadas sem revestimento com blocos de paredes (a) vazadas e (b) maciças

Figura 4.26 - Elevação de temperatura nas pequenas paredes compartimentadas com blocos de paredes vazadas revestidas com argamassa de (a) cimento e (b) gesso 1:2 130

Figura 4.27 - Micrografias dos revestimentos em argamassas de (a) cimento e (b) gesso 1:2

Figura 4.28 - Elevação de temperatura em (a) pasta de gesso, com a/g =0,45 e (b) argamassa de gesso $1: 2$, com a/g $=0,70$ e areia fina 132

Figura 4.29 - Micrografias dos revestimento em gesso (a) pasta e (b) argamassa 1:2. 132 Figura 4.30 - Ciclo típico de aquecimento e resfriamento dos ensaios de simulação de incêndio-padrão.

Figura 4.31 - Superfícies de elevação de temperatura na seção transversal das pequenas paredes sem revestimento compartimentadas com blocos de paredes (a) vazadas e (b) maciças 134

Figura 4.32 - Elevação da temperatura interna dos trios de pequenas paredes compartimentadas 135

Figura 5.1 - Danificação em elementos de alvenaria durante simulação de incêndio-padrão 140

Figura 5.2 - Aspecto superficial dos blocos com paredes (a) vazadas e (b) maciças após situação de incêndio

Figura 5.3 - Aspecto superficial dos (a) prismas e (b) pequenas paredes isoladas após situação de incêndio 141

Figura 5.4 - Aspecto superficial das pequenas paredes sem revestimento compartimentadas com blocos de paredes (a)/(c) vazadas e (b)/(d) maciças após situação de incêndio.

Figura 5.5 - Aspecto superficial das pequenas paredes compartimentadas revestidas com argamassas de (a)/(c) cimento e (b)/(d) gesso após situação de incêndio. 143

Figura 5.6 - Aspecto superficial das camadas de revestimento em argamassas de (a)/(c) cimento e (b)/(d) gesso após situação de incêndio. 143

Figura 5.7 - Ensaio de resistência à compressão em argamassa após situação de incêndio . 144 
Figura 5.8 - Diagramas tensão x deformação da argamassa de assentamento ensaiadas (a) 1 dia (b) 3 dias e (c) 7 dias após situação de incêndio

Figura 5.9 - Modo de ruptura das argamassas de assentamento em (a) temperatura ambiente e (b) 7 dias após situação de incêndio 146

Figura 5.10 - Ensaio de resistência à compressão em bloco após situação de incêndio

Figura 5.11 - Diagramas tensão x deformação dos blocos com paredes (a) vazadas e (b) maciças após situação de incêndio

Figura 5.12 - Modo de ruptura das unidades cerâmicas após situação de incêndio

Figura 5.13 - Ensaio de resistência à compressão em (a) prisma e (b) pequenas paredes após situação de incêndio

Figura 5.14 - Diagramas tensão x deformação dos prismas com blocos de paredes (a) vazadas e (b) maciças após situação de incêndio

Figura 5.15 - Diagramas tensão x deformação das pequenas paredes compartimentadas com blocos de paredes (a) vazadas e (b) maciças após situação de incêndio 151

Figura 5.16 - Diagramas tensão x deformação das pequenas paredes compartimentadas revestidas com argamassa de (a) cimento e (b) gesso 1:2 após situação de incêndio 151

Figura 5.17 - Modo de ruptura dos prismas após situação de incêndio 153

Figura 5.18 - Modo de ruptura das pequenas paredes compartimentadas após situação de incêndio

Figura 5.19 - Curvatura apresentada pelas pequenas paredes compartimentadas revestidas com argamassas de (a) cimento e (b) gesso 1:2.

Figura 5.20 - Diagramas tensão $\mathrm{x}$ deformação conforme face de atuação do fogo nas pequenas paredes compartimentadas revestidas com argamassa de (a) cimento e (b) gesso. 154 Figura 5.21 - Micrografias da argamassa de assentamento a (a) temperatura ambiente e (b)

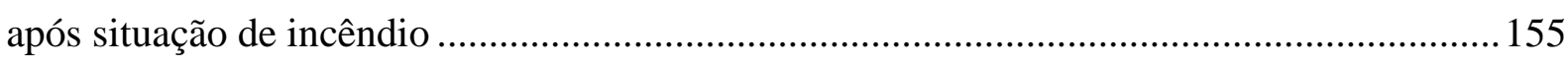

Figura 5.22 - Produção de carbonato de cálcio em argamassa de assentamento..... 156 Figura 5.23 - Aspecto superficial das argamassas de assentamento sob (a) temperatura ambiente, (b) 1 dia, (c) 3 dias e (d) 7 dias após situação de incêndio 157 Figura 5.24 - Variação dos diagramas tensão x deformação das argamassas de assentamento conforme idade após situação de incêndio 157 Figura 5.25 - Micrografias do material cerâmico (a) antes e (b) após a situação de incêndio 158

Figura 5.26 - Densificação do material cerâmico (a) antes e (b) após a situação de incêndio 
Figura 5.27 - Variação da absorção dos blocos cerâmicos após a situação de incêndio ........ 159

Figura 5.28 - Difração de Raio-X para o material cerâmico dos blocos com paredes (a)

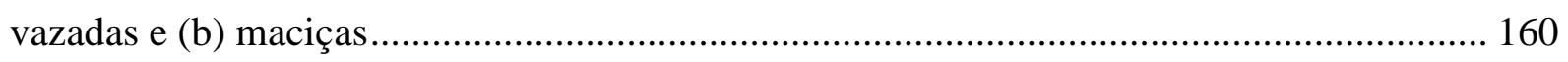




\section{LISTA DE TABELAS}

Tabela 2.1 - Resistência característica à tração na flexão $\left(\mathrm{f}_{\mathrm{tk}}\right)$ e ao cisalhamento $\left(\mathrm{f}_{\mathrm{vk}}\right)$........... 36

Tabela 2.2 - Especificação de argamassa para alvenaria estrutural (em volume) ....................38

Tabela 2.3 - Eficiência parede-bloco na alvenaria estrutural................................................ 39

Tabela 2.4 - Eficiência prisma-bloco na alvenaria estrutural ................................................. 39

Tabela 2.5 - TRRF de acordo com a ABNT NBR 14432:2001 .............................................54

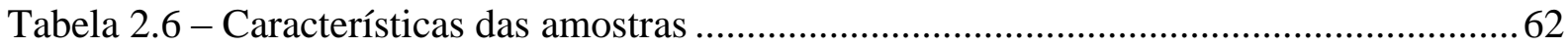

Tabela 3.1 - Especificação das unidades cerâmicas............................................................... 74

Tabela 3.2 - Propriedades avaliadas nas unidades cerâmicas ............................................... 74

Tabela 3.3 - Dimensões médias efetivas das unidades cerâmicas $(\mathrm{mm})$................................. 75

Tabela 3.4 - Espessura dos septos e paredes externas, desvio em relação ao esquadro e

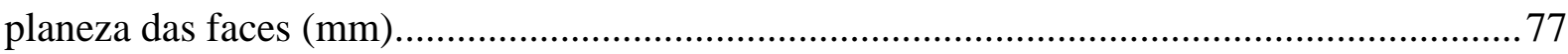

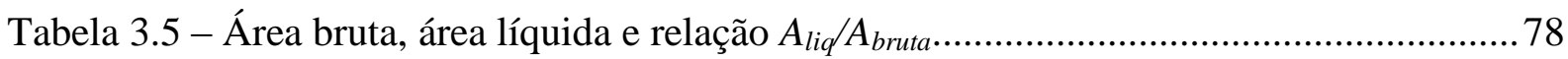

Tabela 3.6 - Massa seca, massa úmida e índice de absorção das unidades cerâmicas ............ 79

Tabela 3.7 - Resistência à compressão e módulo de elasticidade dos blocos cerâmicos.......... 81

Tabela 3.8 - Resistência à compressão e módulo de elasticidade dos meio-blocos ................. 83

Tabela 3.9 - Resistência à tração indireta dos blocos cerâmicos ............................................ 85

Tabela 3.10 - Composição química dos aglomerantes.......................................................... 86

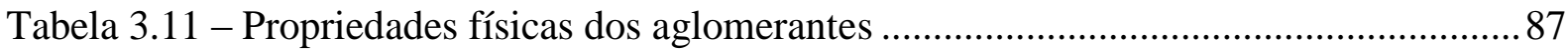

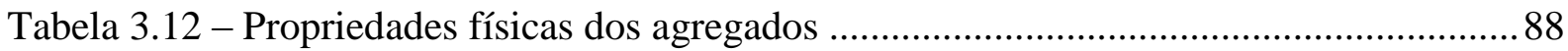

Tabela 3.13 - Propriedades físicas da argamassa de assentamento ......................................... 89

Tabela 3.14 - Propriedades físicas da argamassa de cimento para revestimento......................92

Tabela 3.15 - Propriedades físicas das argamassas de gesso para revestimento ..................... 94

Tabela 3.16 - Propriedades mecânicas da argamassa de cimento para revestimento ..............98

Tabela 3.17 - Propriedades mecânicas das argamassas de gesso para revestimento ...............98

Tabela 3.18 - Propriedades avaliadas nos elementos de alvenaria ...................................... 101

Tabela 3.19 - Resistência à compressão e módulo de elasticidade dos prismas ..................... 103

Tabela 3.20 - Resistência à compressão e módulo de elasticidade de pequenas paredes ...... 104

Tabela 3.21 - Eficiência da alvenaria estrutural em temperatura ambiente ............................ 106

Tabela 4.1 - Propriedades avaliadas dos elementos em situação de incêndio ........................ 110

Tabela 4.2 - Quantidade e especificação dos corpos de prova da fornada I ......................... 112

Tabela 4.3 - Temperatura ambiente e umidade relativa dos corpos de prova da fornada I ... 113

Tabela 4.4 - Quantidade e especificação dos corpos de prova da fornada II. 
Tabela 4.5 - Temperatura ambiente e umidade relativa dos corpos de prova da fornada II . 115 Tabela 4.6 - Quantidade e especificação dos corpos de prova da fornada III

Tabela 4.7 - Temperatura ambiente e umidade relativa dos corpos de prova da fornada III 118

Tabela 4.8 - Especificação da instrumentação dos blocos ................................................ 123

Tabela 4.9 - Especificação da instrumentação dos prismas ............................................... 124

Tabela 4.10 - Especificação da instrumentação das pequenas paredes isoladas ................... 124

Tabela 4.11 - Especificação e instrumentação das pequenas paredes compartimentadas sem

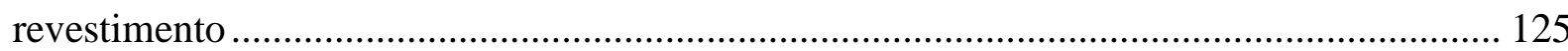

Tabela 4.12 - Especificação e instrumentação das pequenas paredes compartimentadas

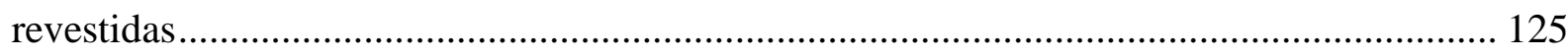

Tabela 4.13 - Especificação e instrumentação dos revestimentos em gesso ......................... 126

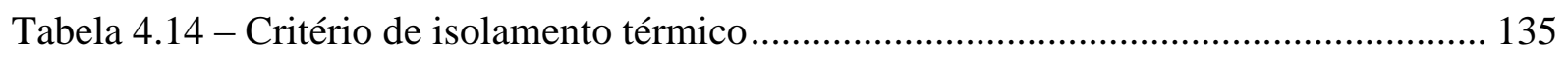

Tabela 5.1 - Propriedades mecânicas da argamassa de assentamento após situação de incêndio 146

Tabela 5.2 - Resistência à compressão e módulo de elasticidade dos blocos cerâmicos após situação de incêndio

Tabela 5.3 - Resistência à compressão e módulo de elasticidade dos prismas após situação de incêndio. 150

Tabela 5.4 - Resistência à compressão e módulo de elasticidade das pequenas paredes compartimentadas após situação de incêndio 152

Tabela 5.5 - Resistência à compressão residual da argamassa de assentamento 158

Tabela 5.6 - Resistência média residual à compressão das unidades e elementos de alvenaria 161

Tabela A.1 - Valores críticos para o teste de Grubbs 177 


\section{SUMÁRIO}

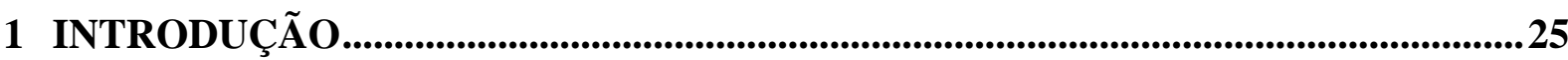

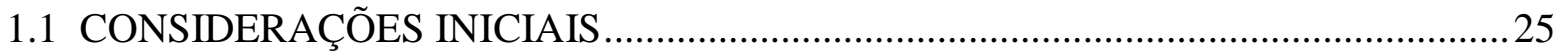

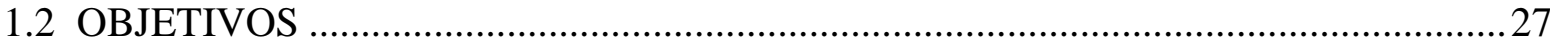

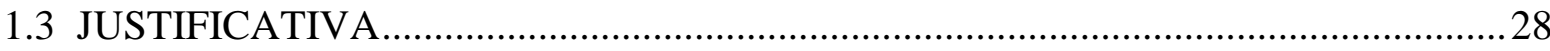

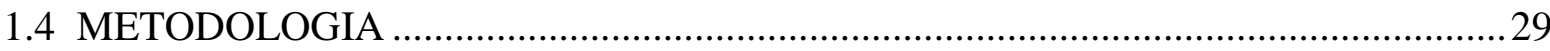

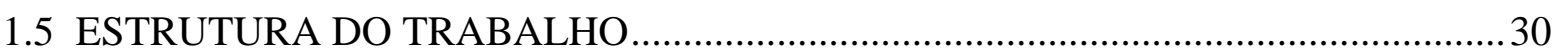

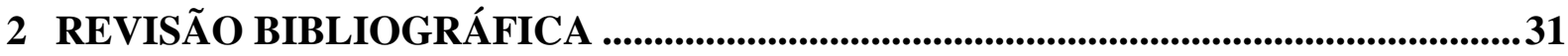

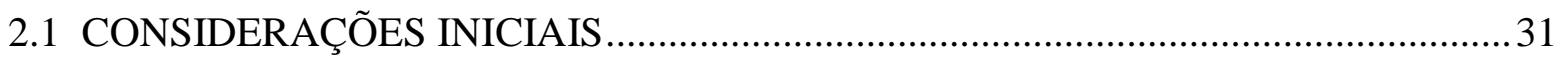

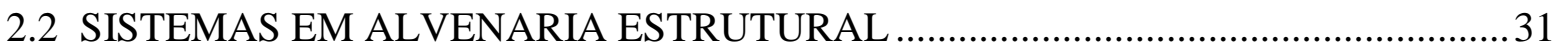

2.2.1 Materiais e componentes .........................................................................................................33

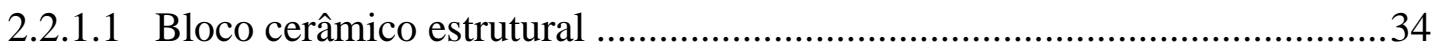

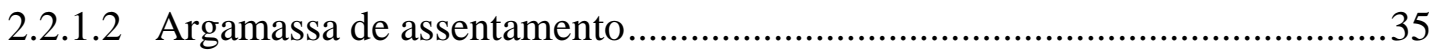

2.2.2 Comportamento mecânico da alvenaria ........................................................................38

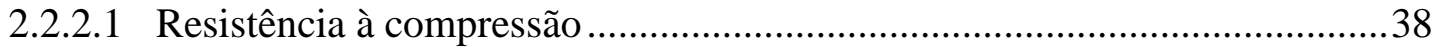

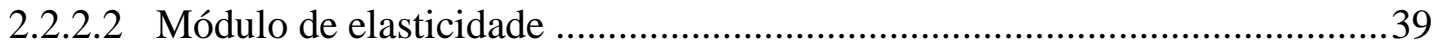

2.3 ESTRUTURAS EM SITUAÇÃO DE INCÊNDIO ................................................. 41

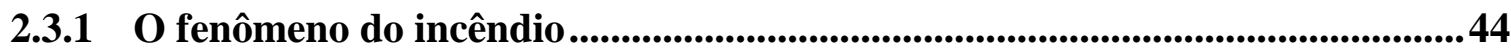

2.3.2 Modelos de incêndio ..........................................................................................................45

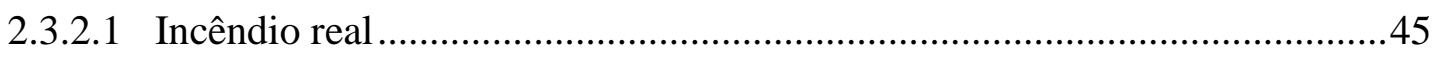

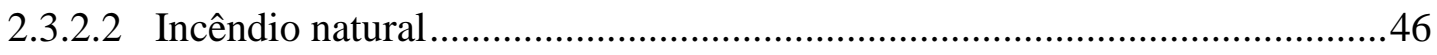

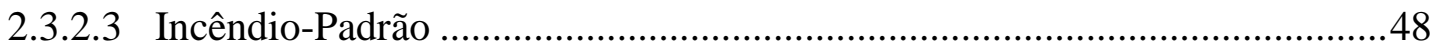

2.3.3 Mecanismos de transferência de calor .............................................................50

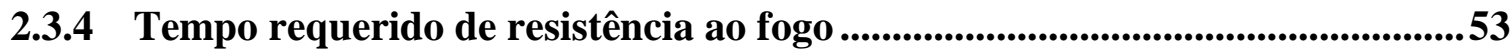

2.4 ALVENARIA ESTRUTURAL EM SITUAÇÃO DE INCÊNDIO ...............................55

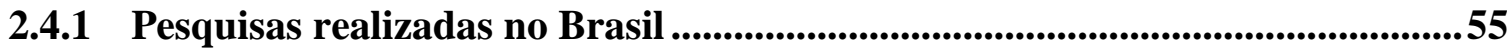


2.4.2 Pesquisas no âmbito internacional 66

2.5 RESUMO DO CAPÍTULO 71

3 PROGRAMA EXPERIMENTAL I: CARACTERIZAÇÃO DOS MATERIAIS E DA

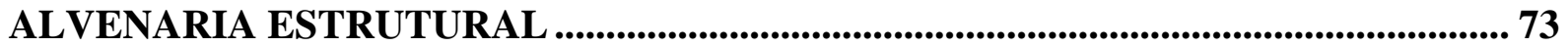

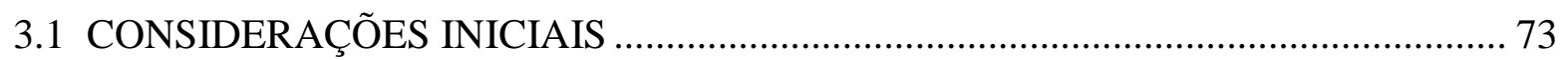

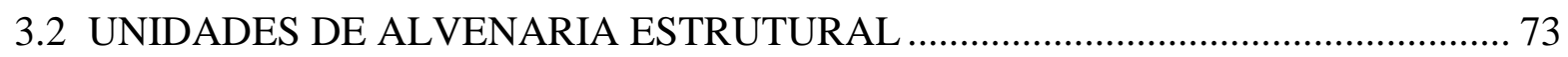

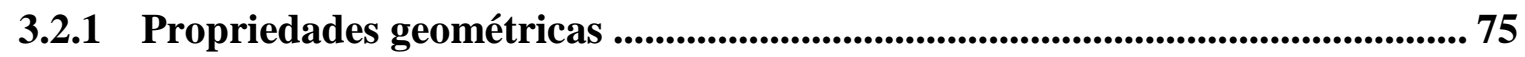

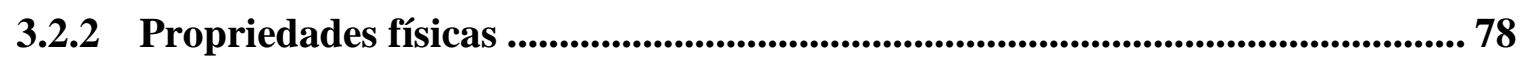

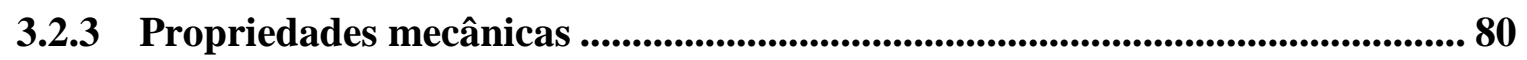

3.2.3.1 Resistência à compressão e módulo de elasticidade .................................. 80

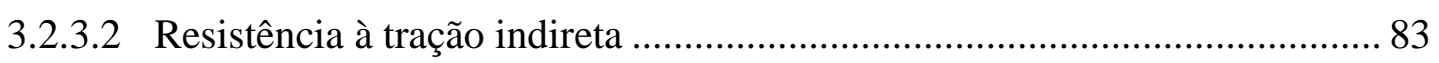

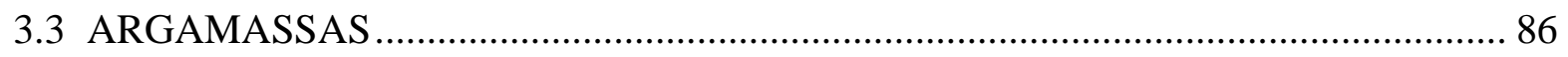

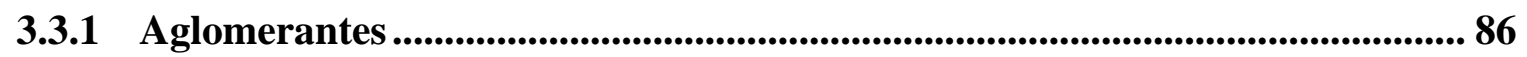

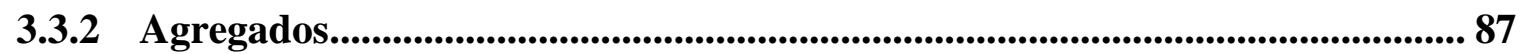

3.3.3 Argamassa de assentamento.......................................................................... 88

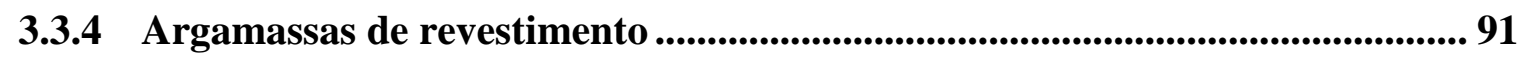

3.4 ELEMENTOS DE ALVENARIA ESTRUTURAL .............................................. 100

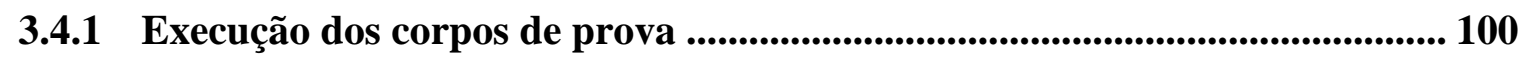

3.4.2 Ensaios de compressão simples e módulo de elasticidade ............................ 102

3.5 EFICIÊNCIA DA ALVENARIA ESTRUTURAL .............................................. 105

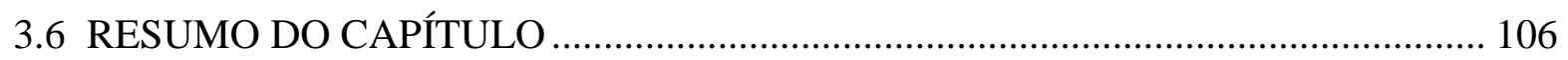

4 PROGRAMA EXPERIMENTAL II - SIMULAÇÕES DE INCÊNDIO-PADRÃO 109

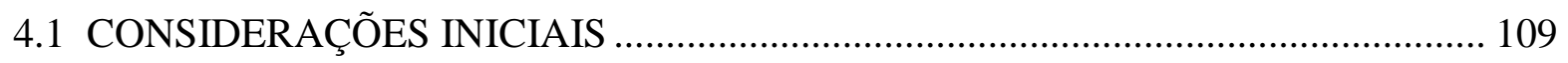

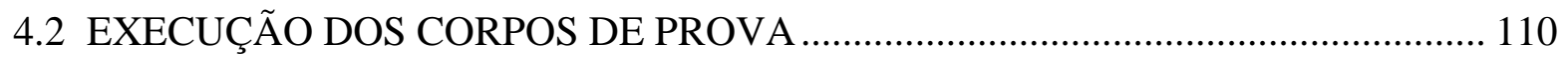

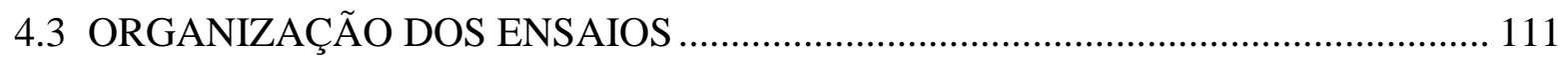

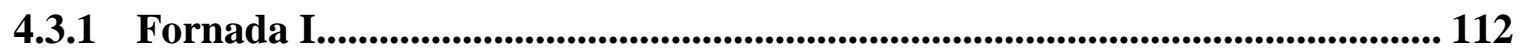


4.3.2 Fornada II .........................................................................................................................114

4.3.3 Fornada III .........................................................................................................116

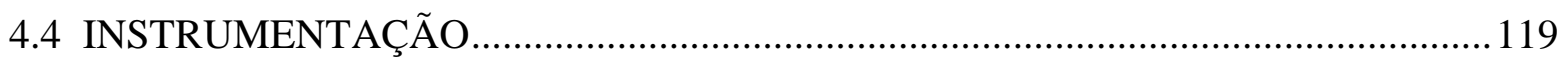

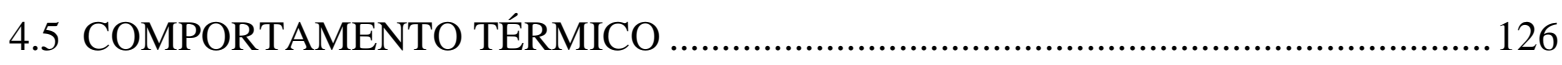

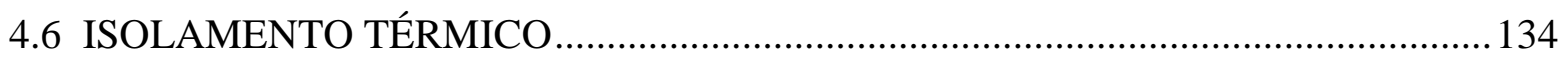

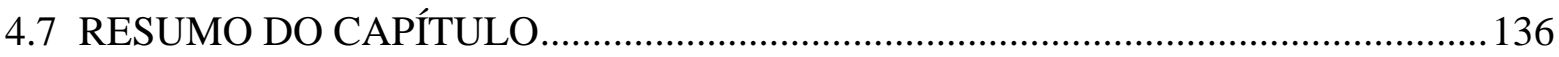

5 PROGRAMA EXPERIMENTAL III - AVALIAÇÃO DO COMPORTAMENTO RESIDUAL .................................................................................................................................139

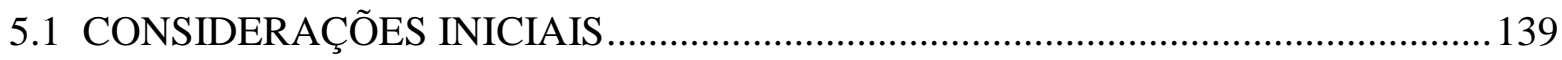

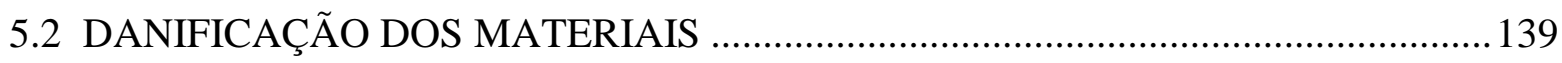

5.3 ENSAIOS DE COMPRESSÃO SIMPLES E MÓDULO DE ELASTICIDADE .........144

5.3.1 Argamassa de assentamento ..........................................................................................144

5.3.2 Unidades cerâmicas .................................................................................................... 147

5.3.3 Elementos de alvenaria estrutural ......................................................................149

5.4 REIDRATAÇÃO DA ARGAMASSA DE ASSENTAMENTO....................................155

5.5 PROPRIEDADES RESIDUAIS DOS ELEMENTOS DE ALVENARIA ......................158

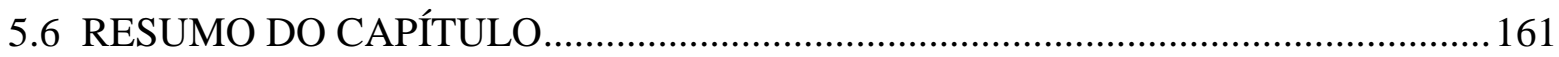

6 CONCLUSÕES E OBSERVAÇÕES FINAIS ...........................................................163

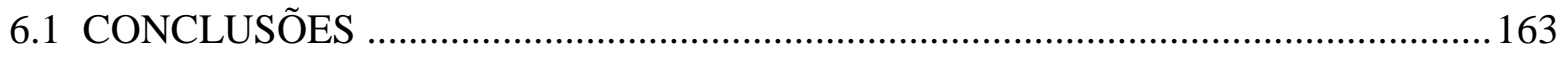

6.2 SUGESTÕES PARA TRABALHOS FUTUROS ...................................................... 166

REFERÊNCIAS BIBLIOGRÁFICAS ..................................................................169

APÊNDICE A - DESCRIÇÃO DO TESTE ESTATÍSTICO DE GRUBBS .....................177

APÊNDICE B - DESCRIÇÃO DOS TESTES ESTATÍSTICOS F E T .............................179 



\section{INTRODUÇÃO}

\subsection{CONSIDERAÇÕES INICIAIS}

A alvenaria estrutural constitui uma das mais antigas soluções estruturais utilizadas pelo homem, e manteve-se consistente até o final do século XIX como o principal material utilizado na construção, em uma época onde seu emprego ainda era fundamentado em métodos empíricos, intuitivos e baseado em experiências anteriores.

De acordo com Ramalho e Corrêa (2003), apesar da cronologia controversa, os primeiros edifícios que surgiram no Brasil datam de 1966, com a execução de edifícios com até quatro pavimentos na cidade de São Paulo, utilizando blocos vazados de concreto. Posteriormente, na década de 70 foram construídos edifícios mais elevados com 12 e 16 pavimentos em alvenaria armada com blocos de concreto.

De acordo com Corrêa (2012), a baixa utilização dos sistemas em alvenaria estrutural durante os primeiros anos pode ser explicada pelo preconceito na utilização de um sistema construtivo não usual, grande domínio das tecnologias de concreto armado e a pequena divulgação do assunto nas universidades durante o processo de formação acadêmica.

Além disso, conforme descrito em Hendry, Sinha e Davies (2004), o emprego deste sistema em edificações mais altas resultava em paredes excessivamente espessas, ocasionando a perca de espaço útil, material e tempo de construção, realidade que estabeleceu com que as obras de alvenaria fossem preteridas em relação a aquelas estruturadas em aço ou concreto armado.

Segundo Capuzzo Neto (2000), as pesquisas nacionais do campo da alvenaria estrutural tiveram início apenas no final da década de 70, em grandes centros de pesquisa como a Escola Politécnica da Universidade de São Paulo (EPUSP), Universidade Federal do Rio Grande do Sul (UFRGS) e no Instituto de Pesquisas Tecnológicas de São Paulo (IPT), e foram publicados no início dos anos 80. Parsekian, Hamid e Drysdale (2014) relatam que o sistema construtivo teve grande crescimento no início dos anos 1990, quando a parceria entre universidades e empresas privadas possibilitou a criação de materiais e equipamentos para produção de alvenaria estrutural. Além disso, a publicação do Manual Técnico da Alvenaria pela Associação Brasileira de Construção Industrializada (ABCI) em 1990 marcou positivamente pela apresentação de conceitos técnicos e construtivos do sistema.

Ao longo dos anos, a alvenaria tem sido amplamente utilizada em edificações residenciais e comerciais de pequeno e grande porte em todo o País. Recentemente, a 
implantação de políticas públicas por parte do governo federal, com a criação de programas habitacionais, favoreceu a aplicação do sistema em alvenaria estrutural, sustentado por vantagens como a redução de custos para edificações de médio porte e rapidez no processo executivo.

Com a vasta utilização do sistema, diversas pesquisas acadêmicas têm sido realizadas com o objetivo de aperfeiçoar técnicas de construção, e colaborar com o entendimento de assuntos técnicos ligados ao projeto dos elementos de alvenaria estrutural, o que possibilitou a publicação de trabalhos científicos e consolidação da normatização nacional com especificação de componentes, projeto, execução, controle de obras e métodos de ensaios dos elementos estruturais em alvenaria.

No entanto, o campo de pesquisas no âmbito nacional que abordam o comportamento destes elementos quando submetidos à situação de incêndio é bastante deficiente, com a publicação dos primeiros trabalhos realizada apenas na última década, e ainda não se dispõe de um código normativo que trate do assunto.

Conforme Silva (2012), as normas atuais de segurança contra incêndio visam principalmente à proteção da vida, a prevenção de incêndios e sua propagação para fora do compartimento. No que diz respeito à segurança das estruturas em incêndio, a Associação Brasileira de Normas Técnicas (ABNT) apresenta na ABNT NBR 14432:2001, Exigências de resistência ao fogo de elementos construtivos de edificações, algumas condições a serem atendidas pelos elementos estruturais de modo que seja evitado o colapso prematuro dos mesmos quando submetidos à situação de incêndio.

No contexto internacional, Regobello (2007) afirma que a regulamentação de segurança contra incêndio em edificações tem buscado basear-se mais no desempenho dos elementos estruturais construtivos expostos à situação de incêndio, do que nas exigências prescritivas, devido a problemas como a perda da capacidade resistente e baixo isolamento térmico apresentado pelos elementos estruturais quando sujeitos à elevação de temperatura.

A resistência ao fogo de um elemento estrutural pode ser entendida como a capacidade que o mesmo possui de resistir à ação do fogo, preservando a capacidade portante quanto à segurança estrutural, estanqueidade e isolamento térmico ainda que na situação de incêndio. Para a alvenaria estrutural, O Corpo de Bombeiros do Estado de São Paulo através da Instrução Técnica IT-08:2018 recomenda a utilização das prescrições presentes no Eurocode 6 Part 1-2:2005, que estabelece quatro critérios para a verificação da segurança em situação de incêndio. Tais critérios podem ser descritos como: 
- Critério (R) - Resistência mecânica: Declarado como satisfeito quando a função de suporte de carga é garantida durante todo o tempo necessário de exposição ao fogo;

- Critério (E) - Estanqueidade: Assumido como satisfeito quando a passagem de chamas e gases quentes através do elemento é impedida;

- Critério (I) - Isolamento térmico: Considerado satisfeito quando a temperatura média da face não exposta ao fogo não ultrapassar $140{ }^{\circ} \mathrm{C}$ e não exceder $180{ }^{\circ} \mathrm{C}$ em qualquer ponto da superfície exposta;

- Critério (M) - Impacto mecânico: Atendido quando um elemento de separação vertical, com características estruturais ou não, resistir ao impacto de uma ação horizontal com especificações definidas pela EN 1363 Part 2.

Entretanto, de acordo com Leite, Moreno Júnior e Torres (2016), atualmente no Brasil não é dado ênfase ao critério de resistência mecânica, devido à inexistência de uma norma técnica que recomende procedimentos para tal, sendo verificados apenas os demais critérios.

Nesse contexto, neste trabalho foi realizada uma avaliação quanto ao desempenho térmico e mecânico de componentes e elementos de alvenaria estrutural usualmente utilizados no Brasil, através de um estudo experimental de argamassas, blocos, prismas e pequenas paredes de alvenaria estrutural com blocos cerâmicos submetidos à elevação de temperatura, com posterior análise do comportamento mecânico residual.

\subsection{OBJETIVOS}

O objetivo geral deste trabalho foi avaliar o comportamento térmico e mecânico de elementos de alvenaria estrutural com blocos cerâmicos quando submetidos à situação de incêndio, visando à contribuição para a normatização nacional.

Para realização de tal objetivo, desenvolveram-se os seguintes objetivos específicos:

- Analisar o comportamento mecânico residual de argamassas, blocos, prismas e pequenas paredes de alvenaria estrutural após a situação de incêndio;

- Verificar o desempenho térmico e grau de compartimentação dos elementos de alvenaria estrutural em situação de incêndio;

- Avaliar a diferença no comportamento mecânico residual entre as pequenas paredes com ambas as faces e com apenas uma das faces da alvenaria sujeitas à elevação de temperatura; 
- Examinar a influência da adição dos revestimentos em cimento e gesso na resposta térmica e mecânica residual de pequenas paredes de alvenaria estrutural;

- Investigar o comportamento térmico e mecânico das argamassas de assentamento e revestimento dos elementos de alvenaria em temperaturas elevadas;

- Avaliar a influência do fenômeno da reidratação das argamassas de assentamento no seu comportamento mecânico residual.

\subsection{JUSTIFICATIVA}

Conforme mencionado anteriormente, os sistemas estruturais em alvenaria têm sido amplamente utilizados no Brasil, mediante vantagens técnicas e econômicas associadas ao seu emprego. Diversos estudos foram realizados para avaliar-se o comportamento mecânico dos elementos estruturais utilizados no sistema, e que contribuíram com informações técnicas para elaboração de métodos e procedimentos normativos.

Entretanto, o comportamento de tais elementos de alvenaria estrutural quando submetidos à situação de incêndio ainda é pouco abordado nas pesquisas nacionais. Tendo em vista diversos acidentes marcantes com estruturas mediante a ação do fogo que ocorreram nos últimos anos, e a inexistência de um código normativo que regulamente procedimentos para verificação dos elementos de alvenaria estrutural em situação de incêndio, a ABNT criou a comissão de estudo ABNT/CE - 002:123.010 para discutir e estabelecer diretrizes para a elaboração de texto base visando a normatização nacional sobre alvenaria estrutural em situação de incêndio.

Diante disso, através da mobilização de algumas instituições no país, iniciou-se a realização de pesquisas com o objetivo de avaliar o comportamento dos elementos de alvenaria estrutural sob ação de temperaturas elevadas e em situação de incêndio, através da realização de análises teóricas, numéricas e experimentais, levando-se em conta práticas e materiais usualmente utilizados em diferentes regiões do Brasil.

Assim, este trabalho inseriu-se nesse contexto, visando avaliar o comportamento mecânico residual de componentes e elementos de alvenaria estrutural com blocos cerâmicos por meio de ensaios experimentais, fornecendo resultados que ajudam a analisar e compreender o desempenho desses elementos estruturais após a situação de incêndio.

Acrescenta-se ainda que este trabalho fez parte de um projeto de pesquisa específico financiado pela Fundação Nacional da Cerâmica (FUNDACER), órgão vinculado à Associação Nacional de Indústria Cerâmica (ANICER), através do Acordo de Cooperação 
Técnica 001/2019, que visou a obtenção de resultados essenciais para o aperfeiçoamento do setor cerâmico quanto ao desempenho térmico e mecânico do material.

\subsection{METODOLOGIA}

Este trabalho consistiu na realização de um estudo experimental para avaliar o comportamento de elementos de alvenaria estrutural com blocos cerâmicos quando submetidos à situação de incêndio. Para realização do trabalho, esta pesquisa foi dividida basicamente em quatro etapas principais.

A primeira constituiu-se de uma revisão bibliográfica para que os principais conceitos sobre os sistemas em alvenaria estrutural e segurança das estruturas ao incêndio pudessem ser discutidos e aplicados de maneira técnica e consistente nos campos desse trabalho. Nesta etapa, verificaram-se diversos trabalhos científicos com ligação ao tema, tanto no âmbito nacional quanto internacional.

Posteriormente, foram realizados os ensaios experimentais de caracterização dos principais componentes, materiais e elementos utilizados no decorrer da pesquisa. Tais ensaios consistiram na obtenção das propriedades geométricas, físicas e mecânicas das argamassas de assentamento e revestimento, unidades cerâmicas, prismas e pequenas paredes.

Após a caracterização de todos os materiais em temperatura ambiente, iniciou-se a análise destes componentes quando submetidos à situação de incêndio. Inicialmente foi avaliado o comportamento térmico de argamassas, blocos, prismas e pequenas paredes de alvenaria estrutural de material cerâmico, através da obtenção das curvas de elevação de temperatura ao longo da seção transversal dos elementos.

Em seguida, todos os corpos de prova sujeitos à situação de incêndio na fase anterior, foram submetidos a ensaios para avaliação das suas propriedades mecânicas residuais. Realizaram-se ensaios de resistência à compressão e determinação do módulo de elasticidade nos materiais e elementos estruturais, possibilitando a sua avaliação residual. Acrescenta-se que os elementos de alvenaria sujeitaram-se à situação de incêndio sem a ação de qualquer carregamento mecânico devido às limitações para aplicação de carga no forno utilizado para aquecimento dos materiais.

Os ensaios de simulação de incêndio-padrão, assim como grande parte dos ensaios mecânicos, foram realizados no Laboratório de Estruturas da Escola de Engenharia de São Carlos (LE - EESC). Além disso, de posse dos resultados adquiridos durante o desenvolvimento desta pesquisa, realizou-se tratamento e análise de dados com o objetivo de 
compreender o comportamento dos elementos de alvenaria sujeitos às condições de incêndio, e obter informações quanto aos parâmetros, procedimentos e correlações que possam colaborar com o desenvolvimento futuro desta linha de pesquisa.

\subsection{ESTRUTURA DO TRABALHO}

Neste texto, o capítulo 1 aborda as considerações iniciais da pesquisa, os objetivos do trabalho e busca-o inserir no contexto nacional de avaliação de elementos estruturais de alvenaria em situação de incêndio.

No capítulo 2 são discutidas as principais informações quanto aos sistemas em alvenaria estrutural, como materiais e propriedades dos componentes, além dos principais conceitos referentes à segurança das estruturas contra incêndio. Por último apresenta-se uma descrição de trabalhos realizados sobre o assunto nos contextos nacional e internacional.

O capítulo 3 apresenta a caraterização dos componentes, materiais e elementos de alvenaria estrutural, com a realização de ensaios experimentais para avaliar os materiais utilizados quanto às propriedades geométricas, físicas e mecânicas.

O capítulo 4 aborda a etapa experimental em que foram realizados os ensaios de simulação de incêndio-padrão, com informações quanto à organização dos ensaios, instrumentação e obtenção das curvas de elevação de temperatura nos elementos analisados.

No capítulo 5 são descritos os principais resultados sobre o comportamento mecânico residual das argamassas, blocos, prismas e pequenas paredes avaliadas neste trabalho.

O capítulo 6 descreve as principais conclusões do estudo quanto ao programa experimental realizado, e apresenta algumas sugestões que podem ser implementadas em pesquisas futuras ligadas a esta linha de pesquisa. 


\section{REVISÃO BIBLIOGRÁFICA}

\subsection{CONSIDERAÇÕES INICIAIS}

Apresentaram-se neste capítulo os principais conceitos acerca dos sistemas em alvenaria estrutural, materiais e componentes que constituem o sistema, tal como uma breve discussão a respeito do comportamento mecânico dos elementos de alvenaria estrutural e os mecanismos de ruptura que regem os mesmos.

Em seguida, discorreu-se sobre os conceitos do fenômeno de incêndio, ao qual este trabalho também esteve inserido, apresentando a caracterização quanto ao desenvolvimento de suas principais fases, assim como os principais modelos de incêndio e os mecanismos de transferência de calor nas estruturas. Neste mesmo item tratou-se sobre os conceitos de Tempo Requerido de Resistência ao Fogo (TRRF) e compartimentação estabelecida pelos elementos estruturais, além das principais modificações no comportamento desses elementos quando submetidos às temperaturas elevadas.

Por fim, apresentou-se a descrição dos principais estudos realizados no Brasil e no exterior com o objetivo de avaliar o comportamento dos elementos de alvenaria sob ação do incêndio, com foco principal aos elementos compostos pelas unidades cerâmicas de alvenaria, às quais se destina esta pesquisa.

\subsection{SISTEMAS EM ALVENARIA ESTRUTURAL}

Atualmente, a alvenaria é um dos sistemas construtivos mais usuais que existem. Conforme Ramalho e Corrêa (2003), esse é um sistema muito tradicional que vem sendo utilizado desde o início da atividade humana com fins diversos. Inicialmente sustentadas pelo emprego de blocos de argila, pedra e outros materiais, diversas construções seculares como as Pirâmides de Guizé, o Farol de Alexandria e o Coliseo Romano foram erguidos utilizando-se dos conceitos do sistema e permaneceram incólumes durante muitos anos.

Para os mesmos autores, o principal conceito estrutural ligado à utilização dos sistemas estruturais em alvenaria, e que viabiliza a sua aplicação no processo construtivo para elaboração de estruturas, é a transmissão das ações através do surgimento de tensões de compressão.

Recentemente, com o aumento gradual da concorrência no mercado e das exigências construtivas, muitas construtoras atreladas aos conceitos de maior racionalização do processo 
construtivo, redução de custos e aumento da produtividade, encontraram nesse sistema construtivo uma possibilidade de melhoria na produção.

De acordo com Mohamad (2007), as grandes vantagens econômicas proporcionadas pela alvenaria estão ligadas à otimização do processo de construção através da utilização de técnicas simplificadas de execução, facilidade no controle das diversas etapas das obras e redução do desperdício de materiais, pela economia de fôrmas, revestimentos e especialidades de mão de obra.

A alvenaria estrutural é um sistema construtivo onde as paredes funcionam como elementos estruturais, suportando aos carregamentos e ações de naturezas distintas, e também como elementos de vedação, responsabilizando-se pela divisão e proteção dos ambientes. Para Parsekian, Hamid e Drysdale (2014), em ambas as situações, estas paredes podem ser construídas de maneira aparente, texturizada ou revestida, e essa dupla função do sistema exige uma grande compatibilização entre os projetos estrutural, arquitetônico e de instalações, com a exigência de que estes sejam elaborados de maneira sequencial e interativa.

Os elementos estruturais em alvenaria constituem-se principalmente de blocos, juntas de argamassa, e eventualmente contam com a presença de graute, armaduras e revestimento. O bloco é o componente básico e principal contribuinte para a resistência à compressão dos elementos estruturais. Usualmente, estas unidades (blocos) podem ser de concreto, cerâmica ou sílico-calcáreas, sendo os dois primeiros, os mais utilizados no Brasil.

Segundo Parsekian, Hamid e Drysdale (2014), até pouco tempo, as edificações em alvenaria estrutural eram construídas em sua grande maioria com alvenaria não armada. Com o aumento dos vãos das edificações e a redução gradual da espessura das paredes, foram introduzidas no setor da construção civil as alvenarias armadas e protendidas. Nesse contexto, a ABNT NBR 15812-1:2010, Alvenaria estrutural - Blocos cerâmicos, subdivide os elementos de alvenaria estrutural conforme a função desempenhada em:

- Elemento de alvenaria não armado - Em que a armadura é desconsiderada para resistir aos esforços solicitantes, acarretando na presença de armaduras apenas de cunho construtivo, utilizadas em regiões específicas para conceder maior ductilidade ao elemento estrutural em regiões de elevadas concentrações de tensão;

- Elemento de alvenaria armado - Aqueles onde são utilizadas armaduras passivas que são consideradas no cálculo para resistir aos esforços solicitantes, comumente necessárias para aumento da resistência à tração e ao cisalhamento da alvenaria;

- Elemento de alvenaria protendido - Onde são utilizadas armaduras ativas, eventualmente fundamentais para redução dos esforços de tração em elementos 
estruturais sujeitos predominantemente à flexão com muros de arrimo, silos, vigas e painéis de fachada.

De acordo com Soares (2011), além da resistência à compressão, os blocos também são responsáveis por grande parte das características das paredes de alvenaria como: estabilidade, precisão dimensional, resistência ao fogo, isolamento térmico e acústico, estética, além da resistência à tração, ao cisalhamento e durabilidade da estrutura. Na Figura 2.1 são apresentados edifícios residenciais em alvenaria estrutural com ambos os componentes.

Figura 2.1 - Edifícios em alvenaria estrutural com blocos de concreto e cerâmicos
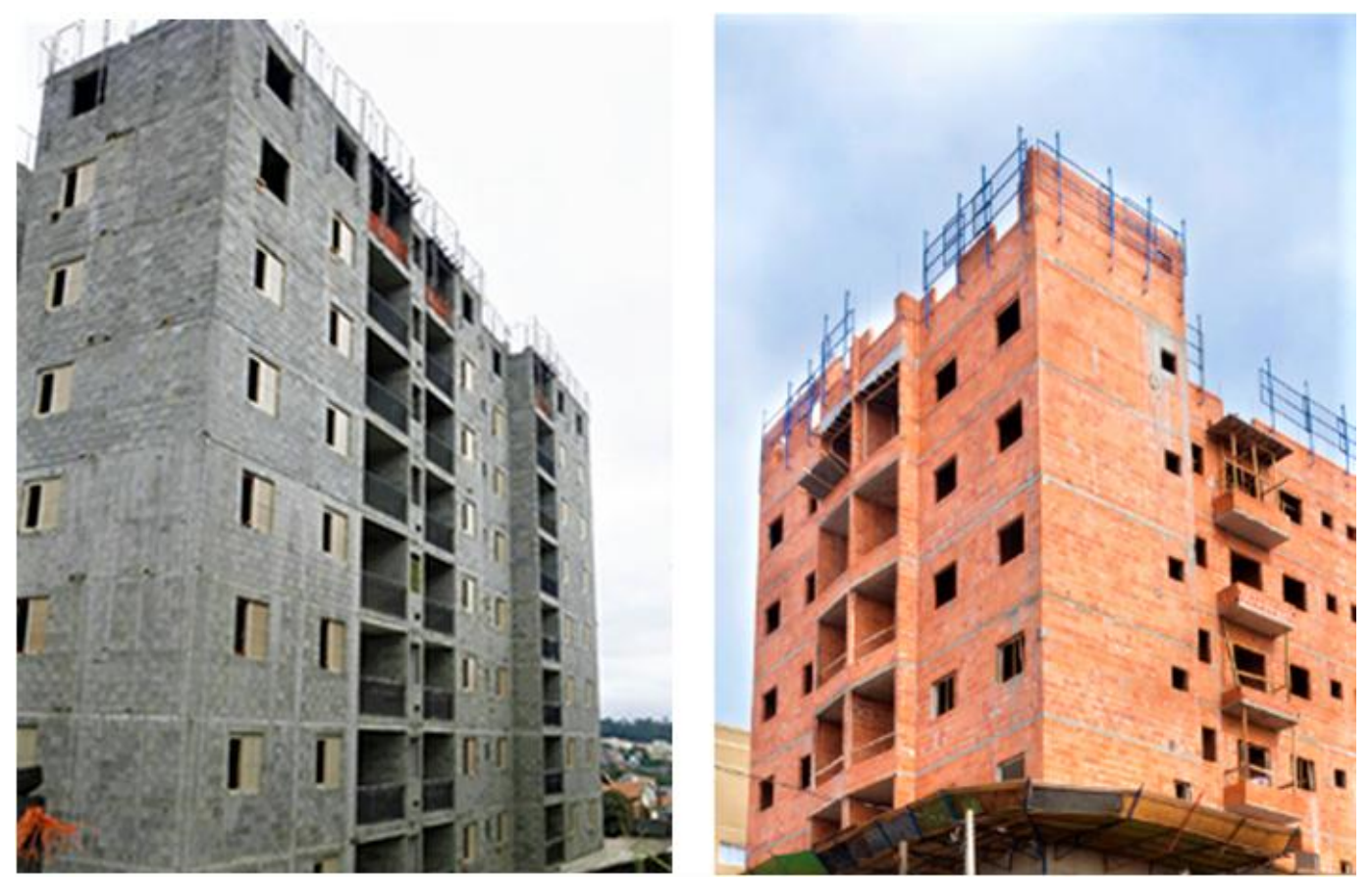

Fonte: JB Blocos (2013) e Cerâmica City (2019).

No Brasil, o projeto, execução, controle de obras e requisitos dos principais elementos e componentes dos sistemas em alvenaria estrutural é normatizado pela Associação Brasileira de Normas Técnicas (ABNT). Para os blocos de concreto, as recomendações são realizadas através da ABNT NBR 6136:2016, Blocos vazados de concreto simples para alvenaria e, ABNT NBR 15961:2011, Alvenaria estrutural - Blocos de concreto, e para os blocos cerâmicos mediante a ABNT NBR 15270:2017, Componentes cerâmicos - Blocos e tijolos para alvenaria e ABNT NBR 15812:2010, Alvenaria estrutural - Blocos cerâmicos.

\subsubsection{Materiais e componentes}

Conforme mencionado anteriormente, a alvenaria estrutural é um sistema compósito 
formado por diferentes tipos de componentes que influenciam diretamente no comportamento dos elementos estruturais. Desta maneira, nos próximos itens serão descritas as características dos principais componentes do sistema, destacando-se os blocos cerâmicos como a principal unidade utilizada neste trabalho, além da argamassa de assentamento dos elementos de alvenaria estrutural.

\subsubsection{Bloco cerâmico estrutural}

Segundo Parsekian, Hamid e Drysdale (2014), tijolos cerâmicos são as unidades de alvenaria mais utilizadas no mundo ao longo do tempo, e sua utilização torna-se viável pela presença de jazidas de argila, principal matéria prima na produção, em diversas regiões do mundo, além do histórico de durabilidade e estética agradável.

Soares (2011) declara que os blocos cerâmicos são produzidos através de um processo inicial de britagem e moagem, onde grandes porções de argilas com características variáveis são estocadas, britadas, misturadas, moídas e peneiradas, para obtenção de plasticidade, resistência mecânica e granulometria padrão. Posteriormente, a mistura é homogeneizada e umedecida até seguir para o processo de formação do bloco através de extrusão da massa plástica mediante extrusora, também conhecida como maromba.

Em seguida, as unidades são destinadas ao processo de secagem de 24 a 48 horas, e então seguem para a etapa de queima, em que permanecem durante aproximadamente 20 horas, submetidos a temperaturas variáveis entre $600{ }^{\circ} \mathrm{C}, 900{ }^{\circ} \mathrm{C}$ e $200{ }^{\circ} \mathrm{C}$, nas fases de préaquecimento, queima e resfriamento, respectivamente.

A ABNT NBR 15270-1:2017 define os blocos cerâmicos estruturais como sendo aqueles com características e propriedades específicas para alvenaria estrutural e, que possuem furos ou vazados prismáticos, produzidos para serem assentados com os furos ou vazados na vertical. Os mesmos devem atender aos requisitos mínimos especificados para utilização e são classificados conforme sua aplicação, em vedação (VED) ou estrutural (EST), seguido da indicação da resistência característica mínima do bloco $\left(f_{b k}\right)$ em quilograma-força por centímetros quadrados $\left(\mathrm{kgf} / \mathrm{cm}^{2}\right)$.

Os blocos estruturais devem apresentar resistência característica mínima de 3,0 MPa, e são classificados quanto à seção transversal entre blocos cerâmicos de paredes vazadas, blocos cerâmicos de paredes maciças, cujas paredes externas são maciças e as internas podem ser maciças ou vazadas, e blocos cerâmicos alveolares, conforme a Figura 2.2. Os primeiros são comercializados das classes EST40 a EST140, com resistência do bloco variando de 4,0 a 
14,0 $\mathrm{MPa}$, e os blocos com paredes maciças e alveolares podem ser encontrados no mercado com resistência entre 4,0 e 20,0 MPa.

Figura 2.2 - Blocos cerâmicos estruturais com parede vazada, maciça e alveolar
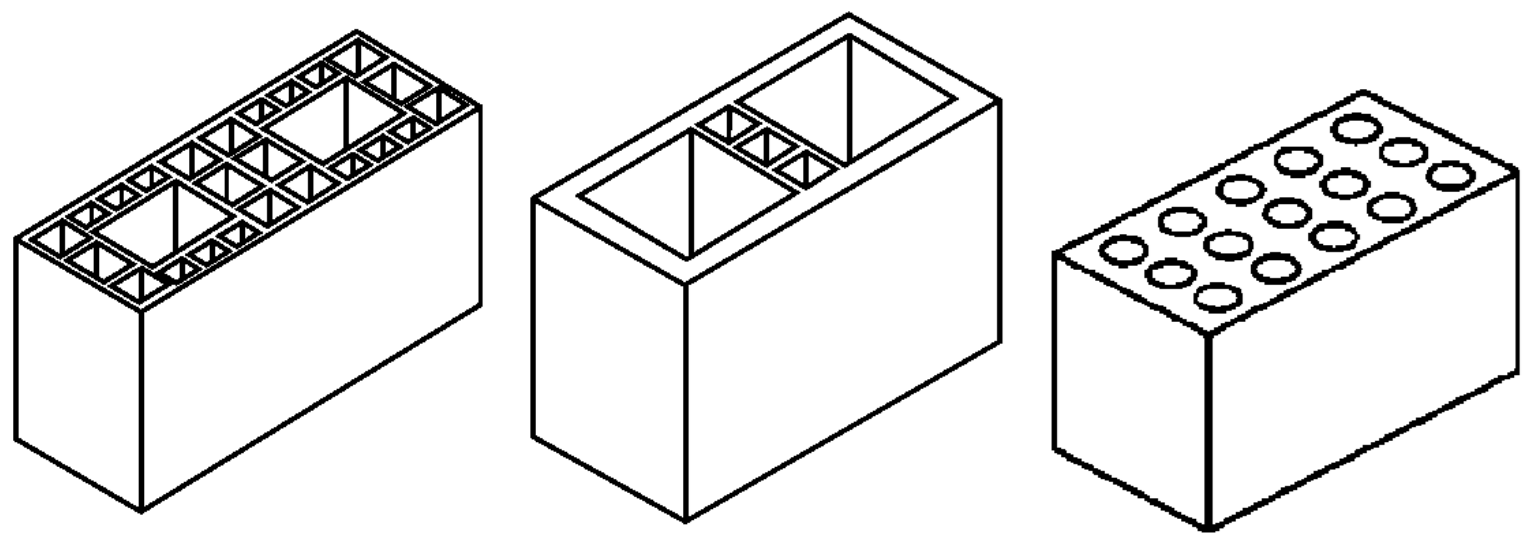

Fonte: Adaptada da ABNT NBR 15270-1:2017.

Conforme Ramalho e Corrêa (2003), a unidade sempre será definida por três dimensões principais. Entre estas, o comprimento e a largura definem o módulo horizontal e, a altura define o módulo vertical a ser adotado na elevação das paredes. Destacando-se que a modulação é um procedimento importante para possibilitar a racionalização do processo construtivo. Usualmente, as unidades cerâmicas estruturais podem ser encontradas com larguras de 14 e $19 \mathrm{~cm}$, e comprimentos de 14, 19, 29, 34, 39 e $44 \mathrm{~cm}$, além de outras medidas com menor disponibilidade no mercado.

\subsubsection{Argamassa de assentamento}

A argamassa de assentamento é utilizada para solidarizar e permitir a aderência entre as unidades de alvenaria, uniformizar e transmitir as tensões atuantes entre estes. Além disso, Ramalho e Corrêa (2003) afirmam que as juntas de argamassa também são capazes de absorver pequenas deformações e resistir às condições ambientais ao longo do tempo, impedindo entrada de água e vento nas edificações.

As argamassas são compostas basicamente de cimento, cal, areia e água. Em geral, o cimento é o principal responsável pela resistência mecânica da mistura, porém, quando usado em quantidades exacerbadas, apesar da elevada resistência, tem-se uma redução na trabalhabilidade e capacidade de acomodação das deformações. A cal contribui para a trabalhabilidade e capacidade de deformação, no entanto, reduz a capacidade resistente da argamassa. Neste âmbito, a areia é um material de baixo custo que viabiliza o uso das misturas de argamassa, através da substituição dos aglomerantes que são mais dispendiosos. 
A avaliação das propriedades da argamassa no estado fresco e endurecido é de suma importância para adequada caracterização da mesma. No estado fresco, a propriedade de maior significado é a trabalhabilidade, que por sua vez, é avaliada através do índice de consistência, que pode ser obtido através do ensaio de consistência descrito na ABNT NBR 13276:2016, Argamassa para assentamento e revestimento de paredes e tetos - Determinação do índice de consistência, onde a argamassa é moldada em um tronco de cone e submetida a uma série de 30 golpes em 30 segundos em uma mesa de consistência. O mesmo código recomenda adotar a quantidade de água necessária para que o índice de consistência da argamassa seja de $260 \mathrm{~mm} \pm 5 \mathrm{~mm}$.

Entre as características mais importantes da argamassa no estado endurecido estão a aderência e a resistência à compressão. Segundo Oliveira (2014), a aderência pode ser definida como a capacidade de transferir tensões de tração e de cisalhamento na interface entre o bloco e a junta de argamassa, se que ocorra a separação entre os dois. A autora destaca ainda que muitos são os fatores que podem influenciar na aderência entre o bloco e a argamassa, destacando-se a relação água/cimento, o teor de água incorporado na mistura, as condições de cura, o tipo de argamassa e as propriedades do bloco.

Para Oliveira (2014), a grande influência da argamassa na aderência bloco-argamassa reflete na resistência à tração e ao cisalhamento da alvenaria, que surgem de maneira frequente quando o sistema estrutural está submetido às ações horizontais. Não obstante, a ABNT NBR 15812-1:2010 apresenta valores para a resistência característica à tração e ao cisalhamento da alvenaria, de acordo com a resistência característica à compressão da argamassa utilizada, conforme a Tabela 2.1.

Tabela 2.1 - Resistência característica à tração na flexão $\left(\mathrm{f}_{\mathrm{tk}}\right)$ e ao cisalhamento $\left(\mathrm{f}_{\mathrm{vk}}\right)$

\begin{tabular}{cccc}
\hline \hline & \multicolumn{3}{c}{ Resistência média de compressão da argamassa (MPa) } \\
\cline { 2 - 4 } & 1,5 a 3,4 & 3,5 a 7,0 & Acima de 7,0 \\
\hline \hline Direção da tração & \multicolumn{2}{c}{ Resistência característica à tração na flexão (MPa) } \\
\hline Normal à fiada & 0,10 & 0,20 & 0,25 \\
Paralela à fiada & 0,20 & 0,40 & 0,50 \\
\hline Local & \multicolumn{2}{c}{ Resistência característica ao cisalhamento (MPa) } \\
\hline Juntas horizontais & $0,10+0,5 \sigma \leq 1,0$ & $0,15+0,5 \sigma \leq 1,4$ & $0,35+0,5 \sigma \leq 1,7$ \\
Interface de paredes & 0,35 & 0,35 & 0,35 \\
com amarração direta & & &
\end{tabular}

Fonte: Adaptada da ABNT NBR 15812-1:2010.

Quanto à resistência à compressão, a ABNT NBR 15812-1:2010 recomenda que as argamassas destinadas ao assentamento de elementos de alvenaria estrutural devem possuir 
resistência mínima à compressão de $1,5 \mathrm{MPa}$ e a máxima limitada a $0,7 \mathrm{f}_{\mathrm{bk}}$, referida à área líquida, e que a espessura das juntas horizontais sejam executadas com $10 \mathrm{~mm}$. Ramalho e Corrêa (2003) afirmam que a argamassa não contribui de forma significativa para a resistência das paredes de alvenaria, e que inclusive variações de resistência na argamassa da ordem de $50 \%$ pouco influenciariam na resistência à compressão da alvenaria. Os autores também chamam atenção para o fato de que a resistência da parede decresce com o aumento da espessura da junta horizontal de argamassa, por conta da diminuição do confinamento da junta devido ao aumento da espessura.

Acrescenta-se ainda que o tipo de assentamento da argamassa exerce uma parcela significativa de contribuição na produção dos elementos de alvenaria e na resistência à compressão dos mesmos. Usualmente, são utilizados dois tipos de assentamento para os elementos de alvenaria. $\mathrm{O}$ assentamento com argamassamento total da junta é aquele onde todas as faces das paredes dos blocos recebem a argamassa, enquanto que no argamassamento parcial a é disposta apenas sobre as paredes longitudinais dos blocos, conforme ilustrado na Figura 2.3.

Figura 2.3 - Junta de argamassamento total e parcial
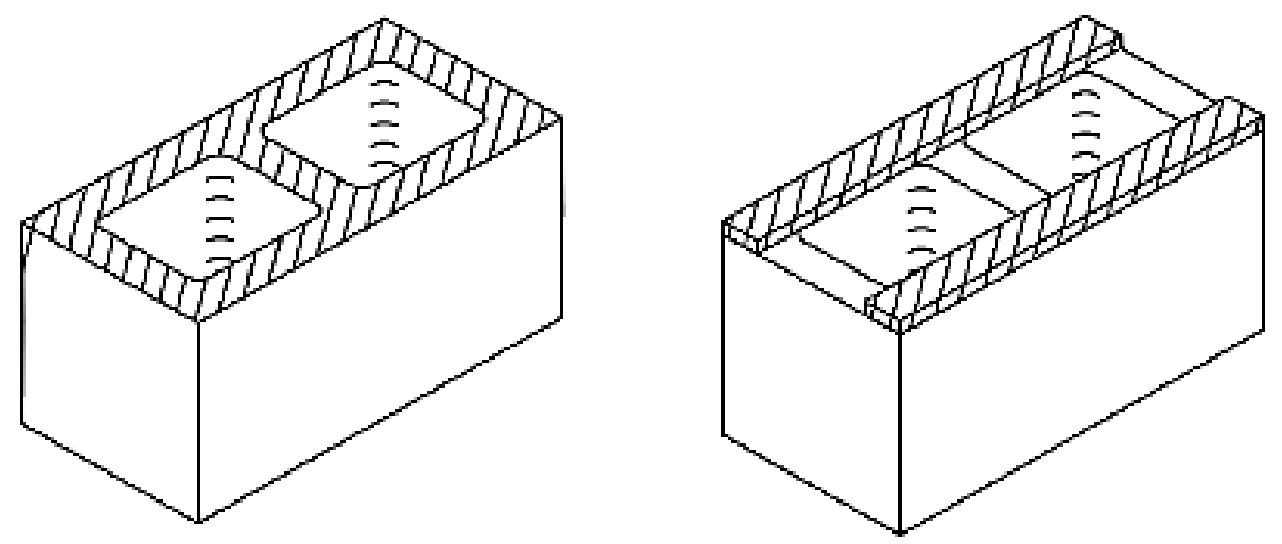

Fonte: Oliveira (2014).

Segundo Oliveira (2014), apesar da economia e maior produtividade de execução ocasionada pela utilização do argamassamento parcial, a ausência da argamassa nos septos transversais dos blocos provoca concentrações de tensões e reduzem a resistência da alvenaria, alterando a distribuição de tensões, fissuração e modo de ruptura das paredes de alvenaria estrutural. Dessa maneira, a ABNT 15812-1:2010 determina que nos casos de argamassamento parcial, a resistência característica à compressão simples da alvenaria deve ser corrigida multiplicando-a pela razão entre a área de argamassamento parcial e a área de argamassamento total. 
Nesse âmbito, baseando-se nas principais características dos componentes da alvenaria estrutural e nas principais características dos materiais que compõem as argamassas usuais utilizadas nos elementos de alvenaria, a BS 5628-1:2005, Code of practice for use of masonry - Structural use of unreinforced masonry, especifica e recomenda a utilização de alguns traços de argamassa, de acordo com o apresentado na Tabela 2.2.

Tabela 2.2 - Especificação de argamassa para alvenaria estrutural (em volume)

\begin{tabular}{cccc}
\hline \hline \multirow{2}{*}{$\begin{array}{c}\text { Designação } \\
\text { da argamassa }\end{array}$} & Tipo de argamassa & \multicolumn{2}{c}{ Resistência média à compressão aos 28 dias (MPa) } \\
\cline { 2 - 4 } & Cimento:cal:areia & Testes laboratoriais & Testes in situ \\
\hline \hline (I) & $1: 0$ a $0,25: 3$ & 16,0 & 11,0 \\
(II) & $1: 0,5: 4$ a 4,5 & 6,5 & 4,5 \\
(III) & $1: 1: 5$ a 6 & 3,6 & 2,5 \\
(IV) & $1: 2: 8$ a 9 & 1,5 & 1,0 \\
\hline \hline
\end{tabular}

Fonte: Adaptada da BS 5628-1:2005.

\subsubsection{Comportamento mecânico da alvenaria}

\subsubsection{Resistência à compressão}

O comportamento mecânico da alvenaria estrutural está associado ao desempenho de cada um dos materiais constituintes do sistema. Em geral, este comportamento é predominantemente influenciado pela resistência das unidades, além de parcelas de contribuição referentes à argamassa de assentamento e execução dos elementos.

A ABNT NBR 15812-1:2010 indica que a resistência característica à compressão simples da alvenaria deve ser obtida através do ensaio de paredes ou estimada como $70 \%$ da resistência do prisma, ou $85 \%$ da resistência da pequena parede. Nos casos em que as juntas horizontais apresentarem argamassamento parcial, quando este for feito apenas nas faces longitudinais dos blocos, a ABNT NBR 15812-1:2010 recomenda que a resistência da alvenaria seja minorada 1,15 vezes a proporção entre as áreas de argamassamento comentadas anteriormente. Para os blocos de concreto, a ABNT NBR 15961-1:2011 sugere que esta resistência seja corrigida pelo fator 0,80 .

Segundo Ramalho e Corrêa (2003), esta relação entre a resistência dos elementos de alvenaria estrutural trata-se de um conceito importante que exprime a influência da resistência dos blocos na resistência da alvenaria estrutural, já que os blocos possuem significativa influência na resistência da alvenaria.

Os autores afirmam que esta eficiência costuma sofrer grande variação a depender da forma, material e resistência dos blocos, além da interferência das propriedades dos outros 
componentes que compõem a alvenaria. Assim, Ramalho e Corrêa (2003) apresentam valores usuais normalmente encontrados nos casos mais comuns no Brasil para a eficiência paredebloco, com os blocos cerâmicos apresentando uma eficiência ligeiramente inferior a aquelas obtidas na alvenaria estrutural com blocos de concreto. Tais resultados podem ser consultados através da Tabela 2.3.

Tabela 2.3 - Eficiência parede-bloco na alvenaria estrutural

\begin{tabular}{ccc}
\hline \hline Material do bloco & Valores mínimos & Valores máximos \\
\hline \hline Concreto & 0,40 & 0,60 \\
Cerâmica & 0,20 & 0,50 \\
\hline \hline
\end{tabular}

Fonte: Ramalho e Corrêa (2003).

No Brasil, os ensaios de resistência à compressão dos prismas são utilizados para a determinação da resistência da alvenaria. Segundo Parsekian, Hamid e Drysdale (2014), tais ensaios também são empregados no controle de qualidade das obras, tendo em vista a praticidade de execução desses corpos de prova e facilidade durante a realização dos ensaios, sem a necessidade de equipamentos de grande porte. Da mesma maneira, Ramalho e Corrêa (2003) empregam o conceito de eficiência para exprimir a relação prisma-bloco, como pode ser visto na Tabela 2.4.

Tabela 2.4 - Eficiência prisma-bloco na alvenaria estrutural

\begin{tabular}{ccc}
\hline \hline Material do bloco & Valores mínimos & Valores máximos \\
\hline \hline Concreto & 0,50 & 0,90 \\
Cerâmica & 0,30 & 0,60 \\
\hline \hline
\end{tabular}

Fonte: Ramalho e Corrêa (2003).

Embora a resistência à compressão da alvenaria seja tratada com maior interesse, diversos autores advertem para algumas situações onde a resistência à tração da mesma das unidades pode ser determinante na resistência e possui influência direta nos mecanismos de ruptura de alguns elementos. Embora com aplicação usual apenas para unidades maciças, a verificação da resistência à tração nos componentes de alvenaria é regularizada pela ASTM C1006-7:2013.

\subsubsection{Módulo de elasticidade}

O módulo de elasticidade consiste em uma propriedade importante na avaliação do comportamento mecânico da alvenaria, com influência na deformabilidade dos elementos e nos seus mecanismos de ruptura. De acordo com Mohamad (1998), muitos estudos foram realizados com o objetivo de estabelecer a relação tensão x deformação para a alvenaria 
estrutural, e consequente valor do módulo de elasticidade para diferentes tipos de blocos e argamassas.

Para o mesmo, tomando como referência um prisma composto por dois blocos, uma estimativa mais consistente do módulo de elasticidade pode ser obtida através da Equação 2.1 especificada abaixo.

$$
E_{a l v}=\frac{h}{\frac{h_{a}}{E_{a r g}}+\frac{2 h_{b}}{E_{b}}}
$$

Onde:

$E_{a l v}$ é o módulo de elasticidade da alvenaria;

$E_{\text {arg }}$ é o módulo de elasticidade da argamassa de assentamento;

$E_{b}$ é o módulo de elasticidade do bloco;

$h$ é a altura total do conjunto (blocos + junta);

$h_{a}$ é a altura da junta;

$h_{b}$ é a altura do bloco.

No entanto, diversos códigos normativos apresentam uma relação simplificada que relaciona o módulo de elasticidade de maneira proporcional com a resistência da alvenaria. $\mathrm{O}$ Eurocode 6 Part 1-1:2005 recomenda a realização de testes experimentais para obtenção das propriedades, porém, na impossibilidade dos ensaios o código propõe que este seja admitido conforme a Equação 2.2.

$$
E_{a l v}=1000 . f_{a l v, k}
$$

Onde:

$E_{a l v}$ é o módulo de elasticidade da alvenaria;

$f_{a l v, k}$ é a resistência característica à compressão da alvenaria.

Para elementos de alvenaria estrutural com blocos de concreto, o ACI 530-05:2005 recomenda a utilização de um módulo de elasticidade conforme a Equação 2.3.

$$
E_{a l v}=900 . f_{a l v}
$$

Onde:

$E_{a l v}$ é o módulo de elasticidade da alvenaria;

$f_{a l v}$ é a resistência à compressão da alvenaria determinada por ensaio de prismas. 
A normalização brasileira através da ABNT NBR 15812-1:2010 e ABNT NBR 159611:2011 para blocos cerâmicos e de concreto, respectivamente, sugere a adoção de valores conforme a Equação 2.4 e Equação 2.5.

$$
\begin{array}{ll}
E_{a}=600 . f_{p k}, \text { para blocos cerâmicos; } & \text { Equação } 2.4 \\
E_{a}=800 . f_{p k}, \text { para blocos de concreto; } & \text { Equação } 2.5
\end{array}
$$

Onde:

$E_{a}$ é o módulo de elasticidade da alvenaria;

$f_{p k}$ é a resistência característica à compressão dos prismas.

Conforme Parsekian, Hamid e Drysdale (2014), os primeiros estudos sobre a relação entre o módulo de elasticidade e a resistência do prisma apontaram proporções variando de 750 a 1000 vezes, porém, ensaios posteriores indicaram valores muito dispersos devido as diferentes configurações do ensaio de prismas, carregamento, instrumentações e métodos de cálculo.

\subsection{ESTRUTURAS EM SITUAÇÃO DE INCÊNDIO}

No contexto mundial, a ocorrência de incêndios é um problema antigo e que afeta a humanidade provocando efeitos catastróficos, como prejuízos ambientais, materiais e a perda de vidas. Historicamente, o grande incêndio ocorrido na cidade de Roma datado de 64 d.C. foi o primeiro incêndio a se ter amplo conhecimento (Figura 2.4). A rápida propagação do incêndio de Roma é atribuída principalmente às formas de apropriação dos espaços e às construções em madeira que eram muito comuns na época.

Figura 2.4 - Grande incêndio de Roma em 64 d.C

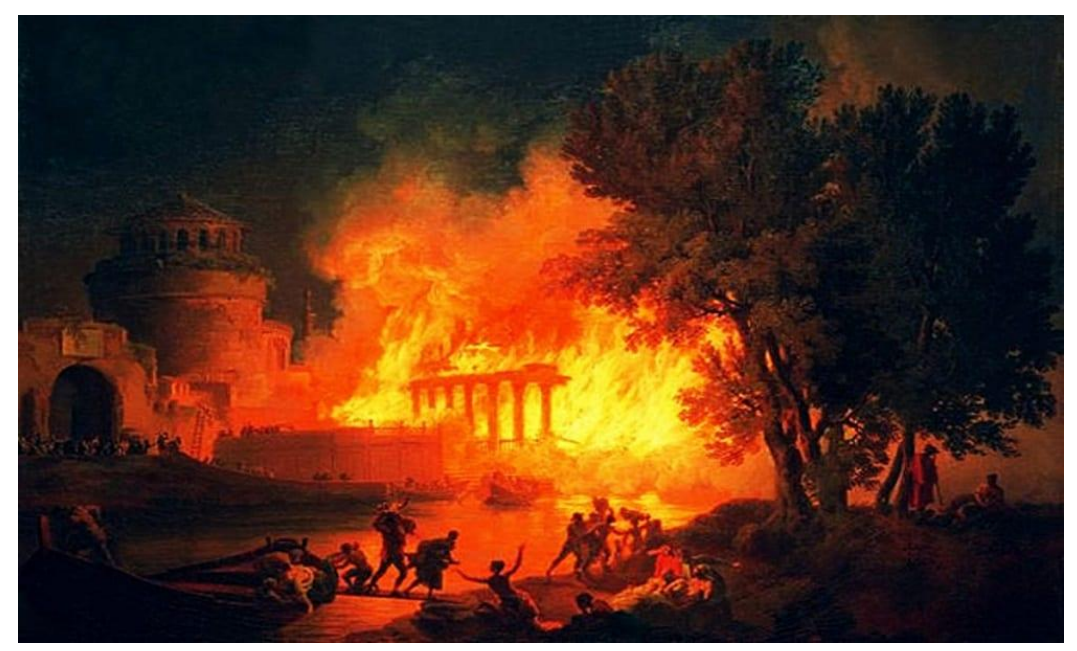

Fonte: Conhecimento científico (2018). 
A ocorrência de grandes incêndios e os danos provocados por estes foram fatores determinantes para o início do estudo da segurança das estruturas em situação de incêndio e para a adoção das primeiras medidas de proteção contra o incêndio. Kirchhof (2004) cita que as exigências de proteção ao fogo surgiram por volta de 1666, após a ocorrência de um grande incêndio na cidade de Londres, considerado como marco na história da segurança contra incêndios urbanos (BONITESE, 2007).

De acordo com a International Association of Fire and Rescue Service - CTIF (2019), a partir de uma base de dados estatística de diversos centros urbanos em 31 países, os incêndios em edificações correspondem a mais de $37 \%$ das ocorrências mundiais, conforme a Figura 2.5. Para a mesma associação, esses incêndios ocorrem em maior número em regiões com grande densidade demográfica, onde o número de vítimas também costuma ser maior.

Figura 2.5 - Distribuição dos incêndios no mundo em 2017 de acordo com o tipo

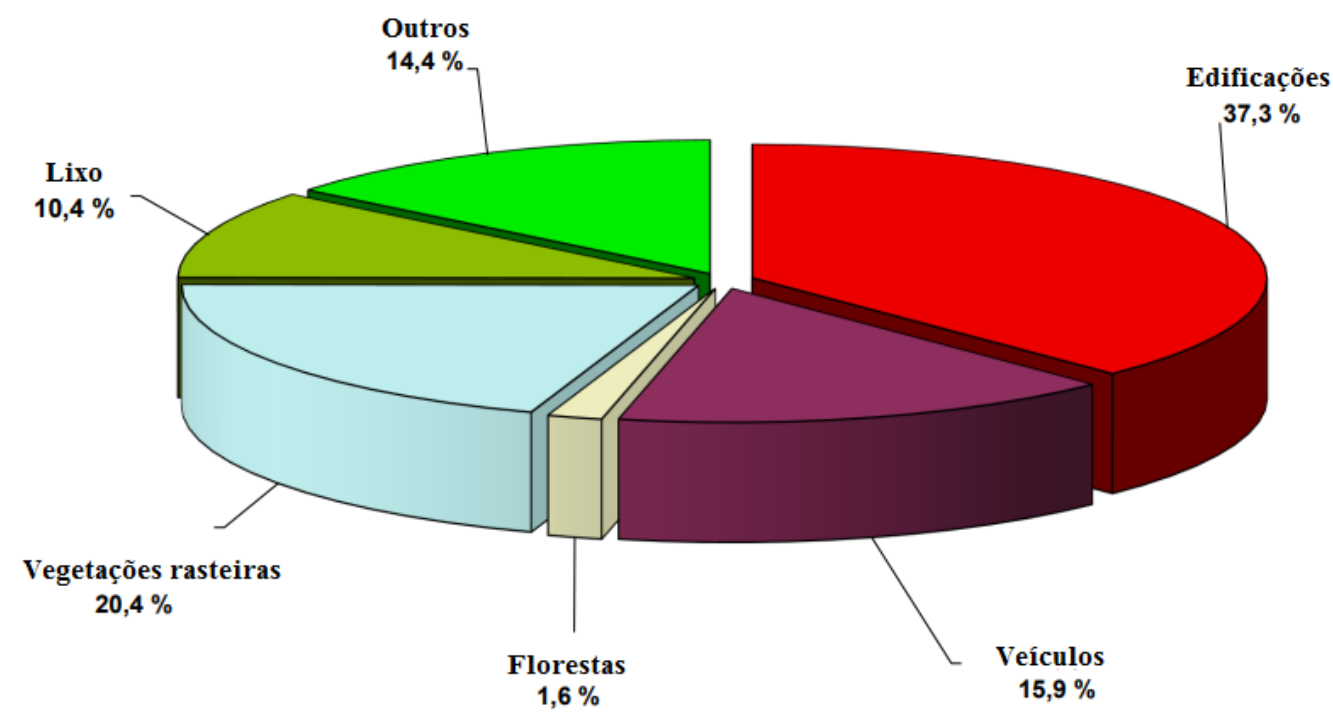

Fonte: Adaptada de International Association of Fire and Rescue Service - CTIF (2019).

Para Buchanan e Abu (2017), a probabilidade de um incêndio grave em qualquer edifício é baixa, mas as possíveis consequências de tal incêndio são enormes. Além disso, os autores afirmam que uma maneira de ganhar experiência na elaboração de projetos e na avaliação quantitativa de riscos em segurança contra incêndios, se dá a partir de análises catastróficas passadas, e visitas a incêndios reais e edificações danificadas pela ação do fogo.

No Brasil, os incêndios ocorridos nos edifícios Andraus e Joelma (Figura 2.6) na década de 70 na cidade de São Paulo, tiveram muito destaque principalmente pela expressiva quantidade de vítimas. Segundo Regobello (2007), estes fatos impulsionaram à procura por soluções e medidas mitigadoras de proteção ao incêndio e minimização de danos, inclusive com o deferimento de um decreto sobre a proteção contra incêndio em edificações. 
Figura 2.6 - Incêndio nos edifícios Andraus e Joelma na cidade de São Paulo
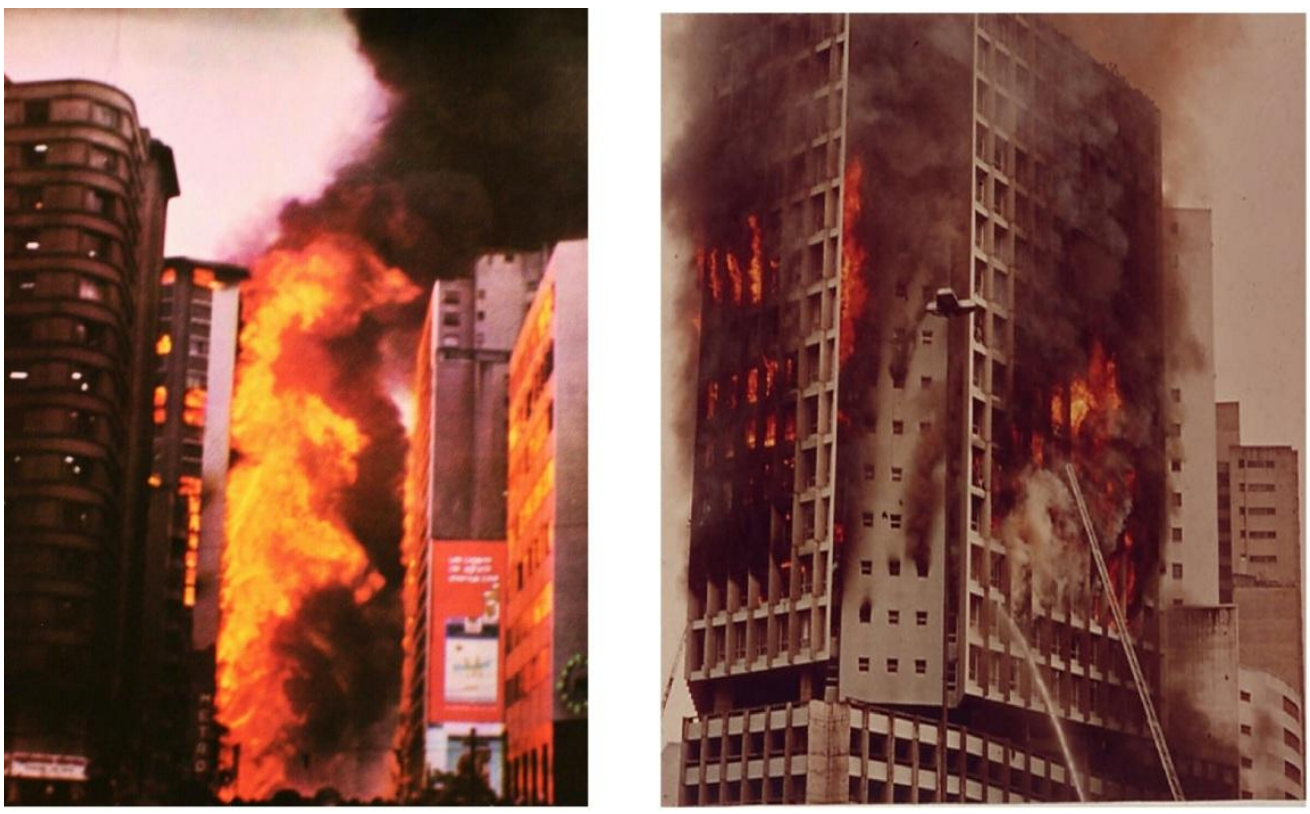

Fonte: Pinterest (1972) e Uol (2014).

De acordo com Silva (2007), nos anos seguintes elaborou-se a ABNT NBR 5672:1980, Exigências particulares das obras de concreto armado em relação à resistência ao fogo, que foi extinta em 2001, e teve seu texto como base para a elaboração da ABNT NBR 15200:2012, Projeto de estruturas de concreto em situação de incêndio.

Em 1996, a Associação Brasileira de Normas Técnicas (ABNT) instalou uma comissão de estudos com representantes do meio universitário da Escola Politécnica da Universidade de São Paulo (EPUSP), Universidade Federal de Minas Gerais (UFMG) e Universidade Federal de Ouro Preto (UFOP), além de outros colaboradores do meio técnico, que possibilitou o desenvolvimento de estudos e pesquisas para a elaboração de outras normas sobre o referido assunto, dentre elas a ABNT NBR 14323:1999, Projeto de estruturas de aço e de estruturas mistas de aço e concreto de edifícios em situação de incêndio (SILVA, 2007).

Atualmente, a ABNT dispõe de diversificadas normas tanto para o projeto de estruturas em situação de incêndio, quanto para a determinação da resistência ao fogo de elementos e componentes construtivos de edificações, além de prescrições com a exigência mínima de resistência ao fogo destes mesmos elementos.

Buchanan e Abu (2007) afirmam que o projeto de elementos estruturais sujeitos à situação de incêndio é realizado a partir da limitação das temperaturas interiores nos componentes estruturais, de modo que haja seção transversal não degradada pela ação do fogo, e que esta seja suficiente para fornecer a resistência estrutural necessária em condições de incêndio. Deste modo, a retenção das temperaturas interiores é realizada a partir da 
utilização de revestimentos e materiais de sacrifício que envolvam e forneçam isolamento para os elementos individuais.

\subsubsection{O fenômeno do incêndio}

Seito et al. (2008) afirma que ainda não há uma definição mundial para definição do fogo, que é o elemento essencial para existência do incêndio. De acordo com a ABNT NBR 13860:1997, Glossário de termos relacionados com a segurança contra incêndio, o fogo é um processo de combustão caracterizado pela emissão de calor e luz.

Para que ocorra a existência do fogo, o mesmo autor indica a necessidade de existência de quatro elementos, que são o combustível, referente ao material que será oxidado, o comburente, que sofrerá a redução durante o processo, o calor ou fonte de ignição e a reação em cadeia, que devem existir coexistir ligados para que o fogo se mantenha. Dessa forma, a associação entre todos os elementos é usualmente representada pelo tetraedro do fogo, apresentado na Figura 2.7.

Figura 2.7 - Representação do tetraedro do fogo

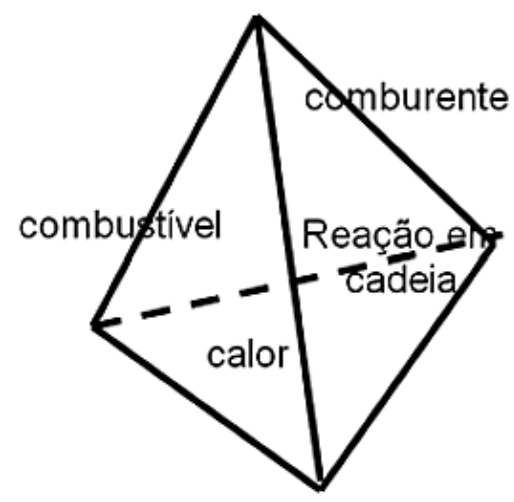

Fonte: Seito et al. (2008).

De acordo com Seito et al. (2008), o fogo sofre a influência de diversos fatores para que possa ser iniciado e permaneça no material combustível. Dentre os fatores destacam-se o estado da matéria, massa específica, superfície específica, calor específico, calor latente de evaporação, ponto de fulgor, ponto de ignição, mistura inflamável, quantidade de calor, composição química, quantidade de oxigênio disponível e a umidade.

Conforme Drysdale (1998), embora o fogo seja uma reação química e que sua existência seja ligada a presença dos quatro elementos citados anteriormente, a velocidade com que ele se propaga depende de alguns fatores, como as condições de abertura e ventilação nas edificações, existência de compartimentos garantidos pelos elementos construtivos, do estado físico e da distribuição do combustível. 
O processo de combustão é definido pela ISO 8421-1:1987 como sendo uma reação exotérmica de uma substância combustível com um oxidante usualmente acompanhada por chamas, abrasamento e/ou emissão de fumaça. Para Nunes (2005), em linhas gerais, este é um processo exotérmico de rápida oxidação de uma substância combustível, geralmente com a presença de oxigênio, acompanhado de uma significativa liberação de energia através de luz e calor.

Por sua vez, o incêndio a ISO 8421-1:1987 estabelece que o incêndio é um processo de combustão rápida que se dispersa de maneira descontrolada no espaço e tempo que está inserido. De forma objetiva, a ABNT NBR 13860:1997 define o incêndio como o fogo fora de controle.

Seito et al. (2008) descreve que são vários os fatores que podem influenciar no início e desenvolvimento de um incêndio, entre os quais podem ser citados, a forma geométrica e dimensões do ambiente, a distribuição dos materiais combustíveis no local, as características de queima dos materiais envolvidos, as aberturas de ventilação do ambiente as condições climáticas instantâneas, entre outros.

Nunes (2005) declara que a grande maioria dos incêndios inicia-se de modo bem pequeno, e que a partir do contato entre uma fonte de energia térmica (fornos, cigarros, fósforos etc.), mecânica (energia liberada em forma de calor por choques mecânicos, como faíscas ou superaquecimento provocados por atrito) ou elétrica (curto-circuito, descargas elétricas etc.), com algum material combustível, dá-se início o processo de combustão, que por sua vez, acarreta na geração de calor, gases e fumaça, responsáveis diretos pelos efeitos nocivos do incêndio.

\subsubsection{Modelos de incêndio}

\subsubsection{Incêndio real}

Em geral, a caracterização da elevação de temperatura em um incêndio é realizada através de uma curva que relaciona a elevação de temperatura em determinado ambiente, com o tempo de ocorrência do incêndio. Desta forma, é possível realizar uma avaliação quanto às diferentes fases de um incêndio, além da possibilidade de identificação dos máximos valores atingidos pelos gases durante a ocorrência do mesmo. De acordo com Seito et al. (2008), a curva representativa de um incêndio real pode ser dividida em três fases distintas, e podem serem observadas através da Figura 2.8. 
Figura 2.8 - Curva característica de um incêndio real

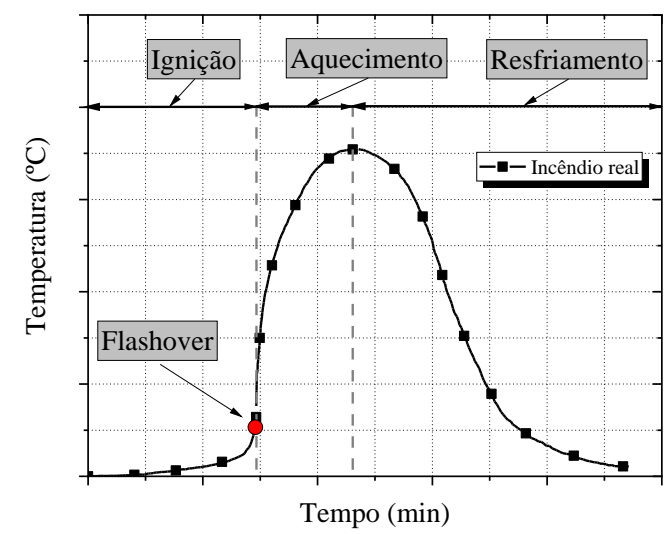

Fonte: Autor (2020).

$\mathrm{Na}$ fase inicial denominada de ignição o incêndio ainda é considerado de pequenas proporções devido às baixas temperaturas. Kimura (2009) menciona que nesta fase o aquecimento ocorre de forma relativamente lento, com fogo localizado em regiões específicas, e com a emissão de uma grande quantidade de fumaça, sendo esta fase também denominada de Pré-flashover.

Segundo Regobello (2007), esta fase não tem nenhuma influência no comportamento estrutural das edificações, porém, é a fase mais crítica tendo em vista a segurança da vida humana, pois durante esse período há uma grande ocorrência de gases tóxicos. Para Seito et al. (2008), antes da fase de ignição há uma etapa conhecida como incêndio incipiente, caracterizado pelo crescimento lendo com duração entre 5 e 20 minutos até a ignição, identificada pelo crescimento das chamas e aquecimento do ambiente.

Após a fase de ignição, o início da fase de aquecimento é definido pela inflamação rápida e rápido aumento de temperatura, denominado flashover, que ocorre quando a temperatura do ambiente se aproxima dos $600^{\circ} \mathrm{C}$, conforme Seito et al. (2008). Nesta fase, toda a carga de incêndio (combustível) do ambiente entra em combustão, e o ambiente é tomado por grandes labaredas, gases e vapores combustíveis.

Com o consumo de todo o material combustível destinado no ambiente, inicia-se a fase de resfriamento, onde ocorre uma diminuição progressiva dos gases devido ao esgotamento do combustível e oxigênio.

\subsubsection{Incêndio natural}

O modelo de incêndio natural foi elaborado através de ensaios e modelos matemáticos, e é considerado como uma simplificação do modelo de incêndio real. Tem como características importantes à aproximação da fase de resfriamento de maneira linear, e a 
desconsideração da fase de ignição do incêndio, baseando-se pelo fato de que as temperaturas alcançadas durante esta fase não influenciam na capacidade resistente dos elementos estruturais.

Desta forma, a curva de incêndio natural mostrada na Figura 2.9 considera apenas a fase ascendente (aquecimento) e o trecho decrescente (resfriamento) utilizando o conceito de tempo efetivo, de modo que seja possível obter os mesmos efeitos de um incêndio real.

Figura 2.9 - Curva característica de um incêndio natural

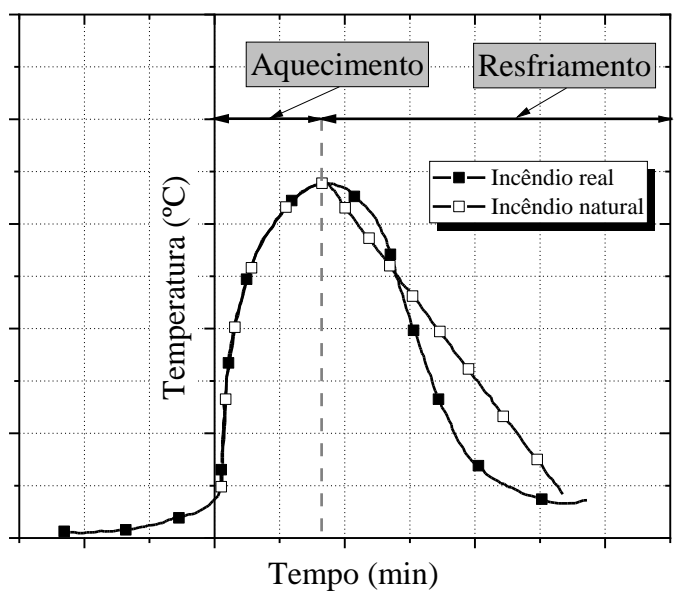

Fonte: Autor (2020).

Segundo Nunes (2005), as curvas de incêndio natural são elaboradas a partir de ensaios experimentais realizados em compartimentos com aberturas, e desenvolvimento do incêndio sem a propagação para o exterior, devido às propriedades de isolamento térmico, estanqueidade e resistência dos elementos de vedação.

A saber, a ABNT NBR 14432:2001, Exigências de resistência ao fogo de elementos construtivos de edificações, indica que isolamento térmico é a capacidade de um elemento construtivo impedir a ocorrência de temperaturas maiores que $140{ }^{\circ} \mathrm{C}$ na média dos pontos de medida, ou $180^{\circ} \mathrm{C}$ em qualquer outro ponto de medida, avaliando-se a face não exposta às chamas. O mesmo código define estanqueidade como sendo a capacidade de um elemento impedir a ocorrência de fissuras ou aberturas, através das quais possam passar chamas e gases quentes capazes de ignizar um chumaço de algodão.

O Eurocode 1 Part 1-2:2002 apresenta duas maneiras para obtenção de curvas parametrizadas de incêndio natural, um modelo simplificado e outro avançado. O modelo simplificado baseia-se em parâmetros físicos específicos e tem campo de aplicação limitado para compartimentos com menos de $500 \mathrm{~m}^{2}$ de área em planta, sem abertura no teto e altura máxima de quatro metros. Neste modelo, a temperatura dos gases poderá ser determinada a partir da densidade da carga de incêndio e condições de ventilação do compartimento. Além 
disso, a distribuição de temperatura deve ser considerada como não uniforme nas situações de incêndios localizados sem a ocorrência de flashover (KIMURA, 2009).

De acordo com Kimura (2009), o método avançado adotado pelo Eurocode 1 Part 12:2002 para consideração da curva de incêndio natural deverá ser empregado mediante utilização de códigos computacionais com aplicação direta à dinâmica dos fluidos, para que seja possível avaliar a evolução da temperatura no compartimento em função do tempo e do espaço. Neste modelo, as propriedades dos gases e a troca de massa e energia também devem ser levadas em conta.

\subsubsection{Incêndio-Padrão}

A grande variabilidade de fatores que podem influenciar na curva tempo $\mathrm{x}$ temperatura de incêndios reais, ocasionou a adoção de uma curva de incêndio-padrão, regulamentada e padronizada por alguns códigos normativos, para servir de modelo para análises experimentais, frequentemente utilizadas em estudos onde não haja parâmetros mais precisos relativos às temperaturas envolvidas (NUNES, 2005).

Esta curva possui apenas o ramo ascendente de aquecimento, e a fase de ignição também é desconsiderada, pelos mesmos motivos mencionados anteriormente. Além disso, o desenvolvimento de temperatura nestas curvas independe da carga de incêndio, do grau de ventilação do ambiente e das propriedades térmicas dos materiais. A ABNT NBR 5628:2001, Componentes construtivos estruturais - Determinação da resistência ao fogo, recomenda a utilização da curva de incêndio-padrão apresentada pela ISO 834-1:1999, que pode ser vista na Figura 2.10.

Figura 2.10 - Curva característica de um incêndio-padrão

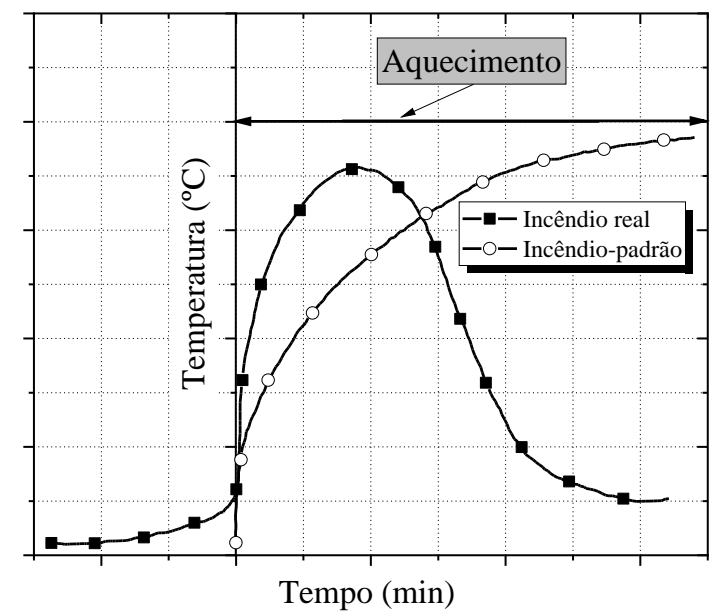

Fonte: Autor (2020). 
A curva tempo $\mathrm{x}$ temperatura indicada pela ISO 834-1:1999 é representada em escala logarítmica (Equação 2.6) e possui como variáveis apenas o tempo de exposição ao fogo e a temperatura inicial de análise, geralmente admitida como $20^{\circ} \mathrm{C}$, conforme Silva (2012). De acordo com o mesmo, a curva 834 é aplicável a situações onde a carga de incêndio tem como principais combustíveis os produtos com potencial calorífico semelhante à madeira, como papel, tecidos, palha etc.

$$
\theta_{g}=345 \log _{10}(8 t+1)+\theta_{0}
$$

Onde:

$\theta_{g}$ é a temperatura dos gases no ambiente em chamas $\left({ }^{\circ} \mathrm{C}\right)$;

$\theta_{0}$ é a temperatura dos gases no instante $\mathrm{t}=0\left({ }^{\circ} \mathrm{C}\right)$;

$t$ é o tempo (minutos).

A ASTM E119:2000 apresenta uma curva tempo $\mathrm{x}$ temperatura por meio de um conjunto de pontos discretos, sem a definição de uma equação para descrevê-la. Segundo Buchanam e Abu (2017), a Equação 2.7 é aquela que melhor retrata a evolução de temperatura segundo este código.

$$
\theta_{g}=\theta_{0}+750\left[1-e^{-3,79533 \sqrt{t}}\right]+170,41 \sqrt{t}
$$

Equação 2.7

Onde:

$\theta_{g}$ é a temperatura dos gases no ambiente em chamas $\left({ }^{\circ} \mathrm{C}\right)$;

$\theta_{0}$ é a temperatura dos gases no instante $\mathrm{t}=0\left({ }^{\circ} \mathrm{C}\right)$;

$t$ é o tempo (minutos).

O Eurocode 1 Part 1-2 (2002) propõe a utilização de três curvas tempo x temperatura para evolução de temperatura em diferentes situações. Uma delas é a curva de incêndiopadrão apresentada pela ISO 834-1:1999, descrita anteriormente neste trabalho, e recomendada para cargas de incêndio formadas por materiais celulósicos. Além disso, a prescrição sugere o emprego da Equação 2.8 para representar o desenvolvimento de temperatura em ambientes e elementos estruturais externos, e a Equação 2.9 para representação de incêndios cujos combustíveis predominantes são derivados do petróleo, ou hidrocarbonetos. Em ambas as equações, $\theta_{g}$ é a temperatura dos gases em chamas $\left(\mathrm{em}^{\circ} \mathrm{C}\right)$ e $t$ o tempo (em minutos). A Figura 2.11 indica todas estas curvas nominais apresentadas.

$$
\theta_{g}=660\left[1-0,687 e^{-0,32 t}-0,313 e^{-3,8 t}\right]+20 \quad \text { Equação } 2.8
$$




$$
\theta_{g}=1080\left[1-0,325 e^{-0,167 t}-0,675 e^{-2,5 t}\right]+20
$$

Figura 2.11 - Curvas padronizadas de incêndio-padrão

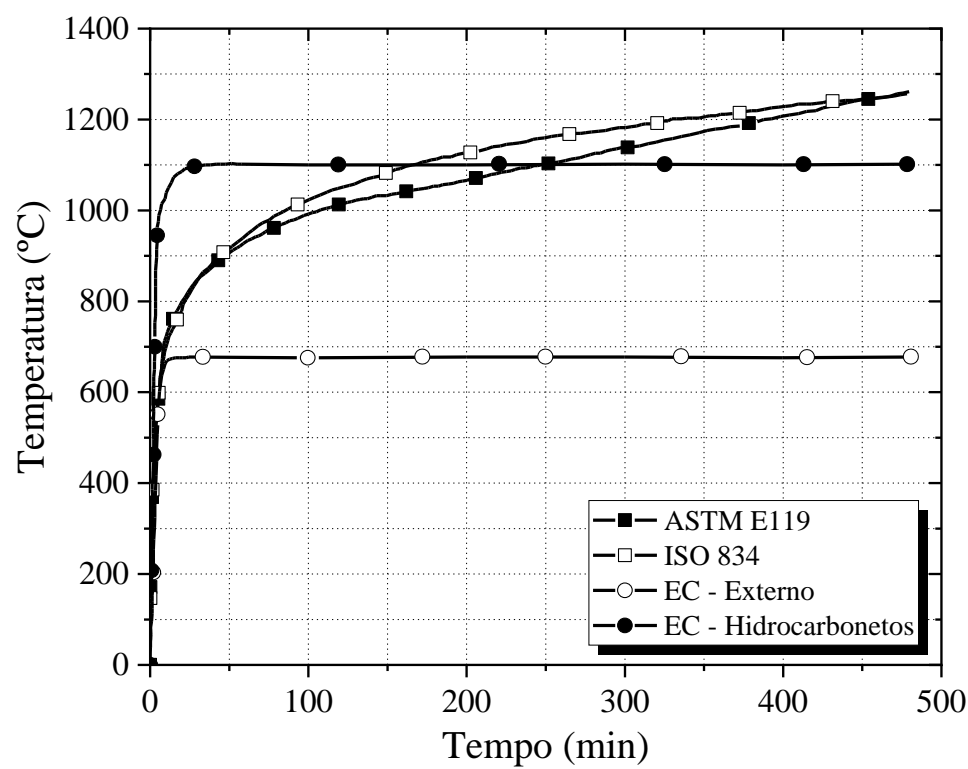

Fonte: Autor (2020).

\subsubsection{Mecanismos de transferência de calor}

Buchanam e Abu (2017) afirmam que o conhecimento a respeito da transferência de calor é essencial para o entendimento do comportamento das estruturas em situação de incêndio, uma vez que as curvas de evolução tempo x temperatura não se referem ao desenvolvimento da temperatura nos materiais, mas nos gases do ambiente em chamas.

Regobello (2007) aponta que o princípio básico de transferência de calor é a diferença entre o gradiente de temperaturas em diferentes pontos da estrutura. Assim, mediante zonas com diferença de temperatura, o calor se direciona dos pontos de maior temperatura para aqueles com menor temperatura. $\mathrm{O}$ processo de transferência de calor ocorre principalmente através de três processos básicos, a condução, a convecção e a radiação, que podem manifestar-se em conjunto ou de forma individual.

Buchanam e Abu (2017) descrevem a condução como sendo um mecanismo de transferência de calor que ocorre em materiais sólidos em decorrência das interações envolvendo elétrons livres nos materiais que são bons condutores de calor, ou devido às vibrações mecânicas da estrutura molecular em materiais que são maus condutores de calor.

A lei física que rege a transferência de calor por condução é denominada de Lei de Fourier, em que o fluxo de calor em decorrência da condução térmica é diretamente 
proporcional ao gradiente de temperatura desenvolvido, conforme Equação 2.10.

$$
\varphi=-\lambda \frac{d T}{d x}
$$

Onde:

$\varphi$ é o fluxo de calor $\left(\mathrm{W} / \mathrm{m}^{2}\right)$;

$\lambda$ é a condutividade térmica do material $(\mathrm{W} / \mathrm{mK})$;

$d T / d x$ é o gradiente de temperatura na direção do fluxo de calor $(\mathrm{K} / \mathrm{m})$.

Em geral, para que seja possível efetuar o cálculo preciso para transferência de calor por condução é necessário um conhecimento amplo quanto as principais propriedades térmicas dos materiais envolvidos, como o calor específico que é definido como a quantidade de calor necessária para aquecer uma unidade de massa do material em um grau (em J/kgK), a condutividade térmica que representa a quantidade de calor transferido através de uma espessura unitária do material por variação de temperatura $(\mathrm{em} \mathrm{W} / \mathrm{mK})$, e densidade do material. Para condições estacionárias, onde as temperaturas são constantes no tempo, é válida a Equação 2.10.

A convecção é a transferência de calor que ocorre pelo movimento dos fluidos. Segundo Buchanam e Abu (2017), este processo é de extrema importância na propagação de chamas ou no transporte de gases quentes no interior do ambiente submetido a uma elevação de temperatura. Kimura (2009) informa que este mecanismo de transferência de calor ocorre na interface entre dois materiais em estados físicos diferentes, e que os fluidos podem encontrar-se tanto no estado líquido, quanto gasoso.

O cálculo para transferência de calor por convecção depende de fatores como a velocidade do fluido na superfície e é diretamente proporcional à diferença de temperatura entre os dois materiais, em concordância com a Equação 2.11 .

$$
\varphi=\alpha_{c} \Delta T
$$

Onde:

$\varphi$ é o fluxo de calor $\left(\mathrm{W} / \mathrm{m}^{2}\right)$;

$\alpha_{c}$ é coeficiente de transferência de calor por convecção $\left(\mathrm{W} / \mathrm{m}^{2} \mathrm{~K}\right)$;

$\Delta T$ é a diferença de temperatura entre a superfície sólida e o fluido (K).

Por último, a radiação é definida com um processo de transferência de calor que ocorre devido à transferência de energia por ondas eletromagnéticas e independem de um 
meio material para se propagarem. Para Buchanam e Abu (2017) esse é o principal mecanismo de transferência de calor das chamas quentes para os materiais combustíveis.

O fluxo de calor por radiação em um ponto da superfície de recepção é dado pela Equação 2.12.

$$
\varphi=\Phi \varepsilon \sigma\left(T_{e}^{4}-T_{r}^{4}\right)
$$

Onde:

$\varphi$ é o fluxo de calor $\left(\mathrm{W} / \mathrm{m}^{2}\right)$;

$\Phi$ é o fator de configuração que indica o quanto o emissor é observado pela superfície receptora;

$\varepsilon$ é a emissividade da superfície emissora;

$\sigma$ é a constante de Stefan-Boltzmann (admitida como 5,67 x $10^{-8} \mathrm{~W} / \mathrm{m}^{2} \mathrm{~K}^{4}$ );

$T_{e}$ é a temperatura absoluta da superfície emissiva (K);

$T_{r}$ é a temperatura absoluta da superfície receptora $(\mathrm{K})$.

Segundo Rosemann (2011), a transferência de calor nos elementos de alvenaria estrutural ocorre por meio da condução, convecção e radiação, sendo este um fenômeno complexo devido às propriedades dos diferentes materiais envolvidos, as reações químicas na composição das argamassas, e da mudança de fase da umidade presente nos materiais. Além disso, como a transferência de calor ocorre em regime transiente, a distribuição de temperatura no interior do elemento estrutural acontece de maneira não linear, conforme a Figura 2.12.

Figura 2.12 - Transferência de calor e distribuição de temperatura não linear em bloco de alvenaria estrutural
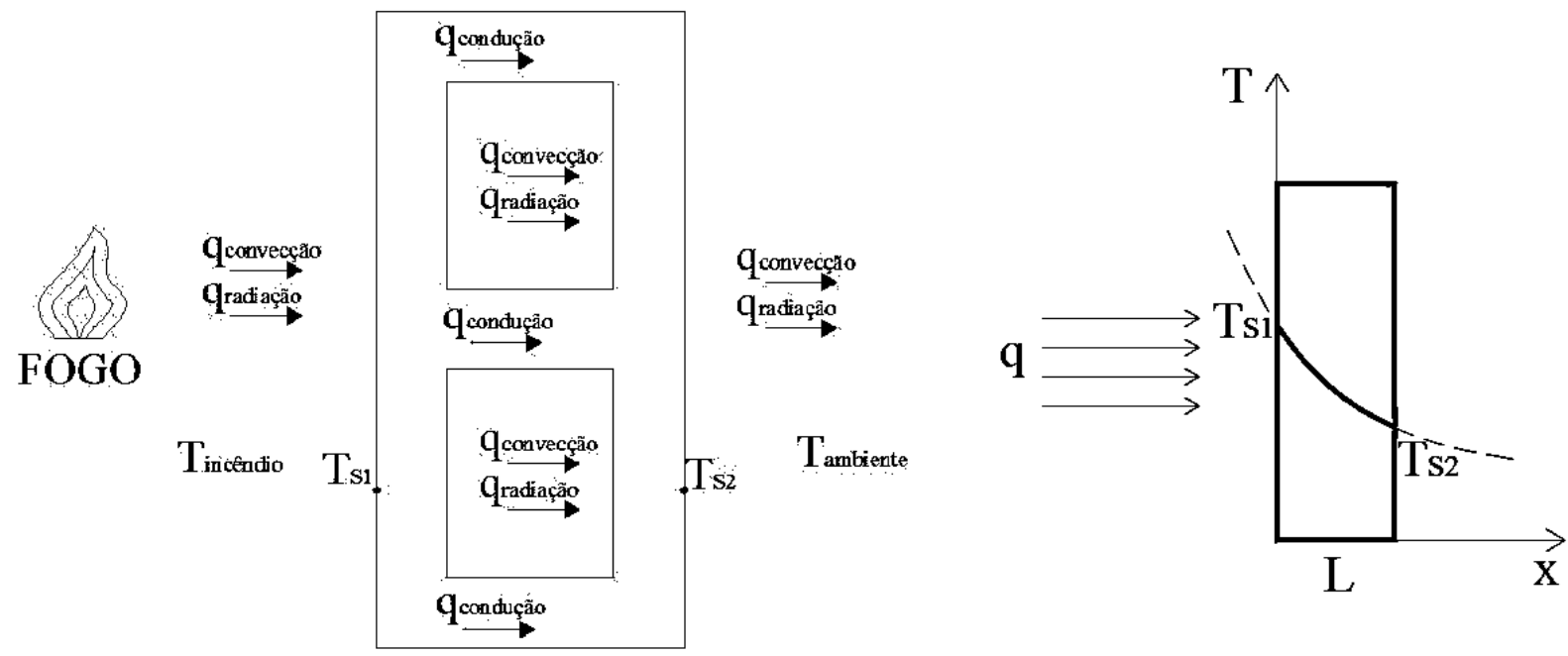

Fonte: Adaptada de Rosemann (2011). 


\subsubsection{Tempo requerido de resistência ao fogo}

O Tempo requerido de resistência ao fogo (TRRF) é definido pela ABNT NBR 14432:2001 como o tempo mínimo que os elementos estruturais e/ou de compartimentação devem resistir aos critérios especificados (resistência, estanqueidade e isolamento) mediante situação de um ensaio de incêndio-padrão, e possui o objetivo de garantir a fuga dos ocupantes, trabalho das operações de resgate e combate ao incêndio, bem como diminuir os danos provocados pelo mesmo.

No entanto, Silva (2012) esclarece que o TRRF constitui apenas um parâmetro para o projeto estrutural, e não estabelece ligação com o tempo de duração do incêndio, tempo de desocupação e tempo de resposta do Corpo de Bombeiros, embora seja apresentado pelo código nacional em forma de tempo.

O conceito de TRRF pode ser mais bem explicado através da Figura 2.13, onde Silva (2008) comenta que a temperatura máxima alcançada pelos elementos estruturais não é a mesma temperatura dos gases envolvidos no incêndio, devido a quantidade e distribuição da carga do incêndio, compartimento e características térmicas, assim a curva de incêndio-padrão não representa um incêndio real, apenas está associado a um tempo fictício padronizado, denominado TRRF.

Figura 2.13 - Conceito de Tempo requerido de resistência ao fogo (TRRF)

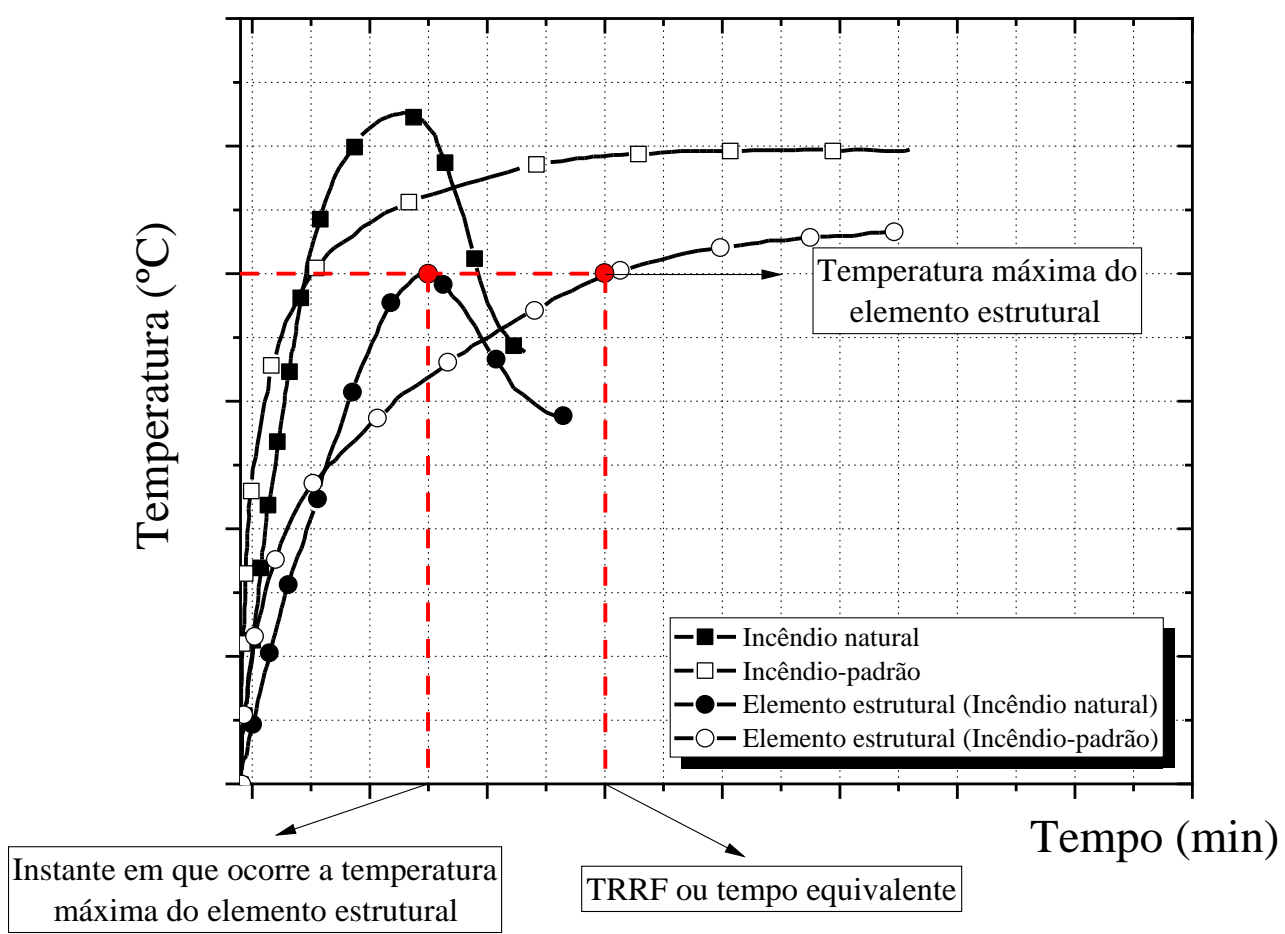

Fonte: Adaptada de Silva (2008). 
No Brasil, o TRRF pode ser obtido pela forma tabular através da ABNT NBR 14432:2001, que está associado ao uso e dimensões das edificações, conforme Tabela 2.5.

Tabela 2.5 - TRRF de acordo com a ABNT NBR 14432:2001

\begin{tabular}{cccccc}
\hline \hline \multirow{2}{*}{ Ocupação/Uso } & \multicolumn{5}{c}{ Altura da edificação (metros) } \\
\cline { 2 - 6 } & $\mathrm{h} \leq 6$ & $6<\mathrm{h} \leq 12$ & $12<\mathrm{h} \leq 23$ & $23<\mathrm{h}<30$ & $\mathrm{~h} \geq 30$ \\
\hline \hline Residencial & 30 & 30 & 60 & 90 & 120 \\
Hospedagem & 30 & 60 & 60 & 90 & 120 \\
Comercial & 60 & 60 & 60 & 90 & 120 \\
Escritórios & 30 & 60 & 60 & 90 & 120 \\
Educacional & 30 & 30 & 60 & 90 & 120 \\
Shoppings & 60 & 60 & 60 & 90 & 120 \\
Industrial & 60 & 60 & 90 & 120 & 120 \\
Depósitos & 60 & 60 & 90 & 120 & 120 \\
\hline \hline
\end{tabular}

Fonte: Adaptada da ABNT NBR 14432:2001.

A Instrução Técnica IT-08 (2018) do Corpo de Bombeiros do Estado de São Paulo, que atualmente corresponde a um importante veículo de boas práticas de segurança ao incêndio em todo o Brasil, também fornece o TRRF através de tabelas. Em grande maioria das situações, estes valores são correspondentes a aqueles encontrados na ABNT NBR 14432:2001, com a diferença de que a IT-08 (2018) estabelece mais duas classes de dimensões para a altura das edificações, variando de 30 a 250 metros.

Adicionalmente, o TRRF pode ser calculado de maneira analítica tendo como base o método do tempo equivalente do Eurocode 1 Part 1-2 (2002) através da Equação 2.13.

$$
t_{e}=q_{f i, k} \cdot \gamma_{n} \cdot \gamma_{s} \cdot W \cdot K \cdot M
$$

Equação 2.13

Onde:

$t_{e}$ é o tempo equivalente mínimo (minutos)

$q_{f i, k}$ é o valor característico da carga de incêndio específica $\left(\mathrm{MJ} / \mathrm{m}^{2}\right)$;

$\gamma_{n}$ é um coeficiente adimensional que considera a presença de medidas de proteção ativa;

$\gamma_{s}$ é um coeficiente de segurança que depende do risco de incêndio e consequências do colapso da edificação;

$W$ é um fator associado à ventilação e altura do compartimento;

$K$ é um fator associado às características do material de vedação do compartimento (min.m²/MJ);

$M$ é um fator que depende do material da estrutura, sendo igual a 1,0 para aço com revestimento contra fogo ou concreto, e 13,7v para aço sem revestimento, onde v é o grau de 
ventilação da edificação.

\subsection{ALVENARIA ESTRUTURAL EM SITUAÇÃO DE INCÊNDIO}

Pela composição dos sistemas em alvenaria estrutural, a resistência ao fogo destes elementos estruturais depende do comportamento resistente à ação de elevadas temperaturas de cada um dos seus componentes. No Brasil, ainda observa-se uma escassez de resultados tanto sobre as propriedades desses materiais em situação de incêndio, quanto sobre o comportamento do próprio sistema estrutural enquanto submetido a elevadas temperaturas. A seguir será apresentada a descrição do estudo realizado por alguns dos trabalhos desenvolvidos acerca da temática em estudo.

\subsubsection{Pesquisas realizadas no Brasil}

$\underline{\text { Rosemann (2011) }}$ realizou um estudo sobre a resistência ao fogo de paredes de alvenaria estrutural com blocos cerâmicos através do critério de isolamento térmico. Desenvolveu-se uma análise experimental utilizando blocos cerâmicos estruturais da família 14x19x29 cm e resistência nominal à compressão de $9 \mathrm{MPa}$ sem carregamento externo aplicado e submetidos a elevação de temperatura em uma das faces seguindo a curva de incêndio-padrão proposta pela ISO 834-1:1999.

Devido ao elevado custo dos ensaios, o autor avaliou experimentalmente apenas um corpo de prova de parede com 2,70 m de comprimento e 2,60 m de altura para cada tipo de configuração. Foram construídas 4 paredes alternando a presença de revestimento em argamassa com 1,5 cm de espessura, e o preenchimento dos vazados dos blocos com areia, conforme apresentado na Figura 2.14. A argamassa utilizada no assentamento dos blocos foi composta por cimento, cal e areia média com traço 1:1:6 em volume que resultou em uma resistência média à compressão de 7,73 $\mathrm{MPa}$.

As paredes foram construídas de modo que atuassem como sendo as delimitações do próprio forno, formando em planta um quadrilátero composto por quatro paredes, sendo as duas paredes testadas distantes $75 \mathrm{~cm}$ entre si, e as duas paredes laterais auxiliares espaçadas em $240 \mathrm{~cm}$, formando um forno com a parte superior preenchida com uma laje de concreto armado com vigotas pré-moldadas. Em cada forno foram posicionados quatro queimadores na parte inferior das paredes por meio de aberturas inseridas nas mesmas, controlados manualmente através de botijões de gás liquefeito de petróleo. 
Figura 2.14 - Configuração dos corpos de prova submetidos à elevação de temperatura

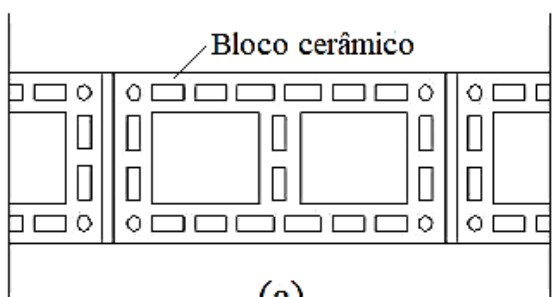

(a)

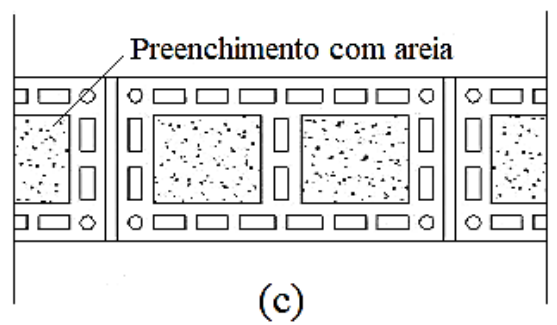

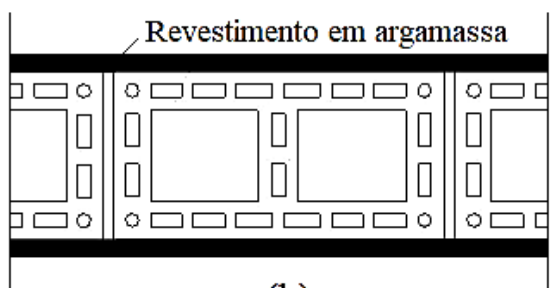

(b)

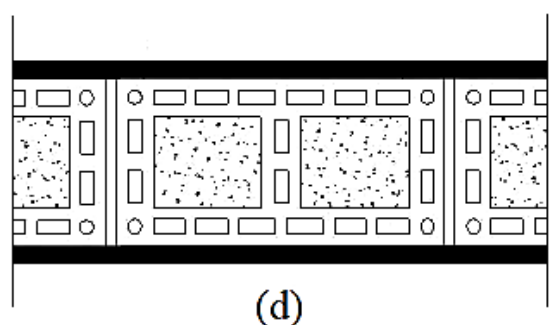

Fonte: Adaptada de Rosemann (2011).

Para o controle de temperatura no interior do forno foram instalados cinco termopares do tipo $\mathrm{K}$ espaçados de maneira uniforme e afastados $10 \mathrm{~cm}$ da face interna de uma das paredes. Para medição da temperatura na face não exposta ao fogo utilizaram-se cinco termopares do mesmo tipo em cada parede, e a variação de temperatura registrada pelos instrumentos foi avaliada segundo o critério de isolamento térmico estabelecido pela ABNT NBR 5628:2001, que considera o elemento satisfatório no tocante ao isolamento, até que a temperatura média na face não exposta ao fogo seja inferior a $140{ }^{\circ} \mathrm{C}$ ou menor que $180{ }^{\circ} \mathrm{C}$ em qualquer ponto isolado.

Os resultados obtidos são apresentados na Figura 2.15 através da variação de temperatura na face não exposta ao fogo para cada configuração de parede. Os patamares observados no desenvolvimento de temperatura para as paredes preenchidas foram atribuídos a destinação de parte do calor que atravessava a parede para a realização da mudança de fase da umidade contida na areia.

Além disso, avaliou-se o tempo de resistência ao fogo de maneira analítica seguindo as recomendações da Brick Industry Association (BIA), obtendo resultados até 28,4\% inferiores a aqueles obtidos experimentalmente, destacando o conservadorismo do método quando aplicado aos blocos cerâmicos usuais utilizados no Brasil. Uma análise numérica empregando o método dos elementos finitos também foi realizada a partir da calibração dos modelos numéricos, onde foi possível reproduzir a transferência de calor através dos blocos em situação de incêndio, verificando a influência das principais propriedades térmicas e do revestimento na resistência ao fogo das paredes de alvenaria. 
Figura 2.15 - Variação de temperatura na face não exposta ao fogo

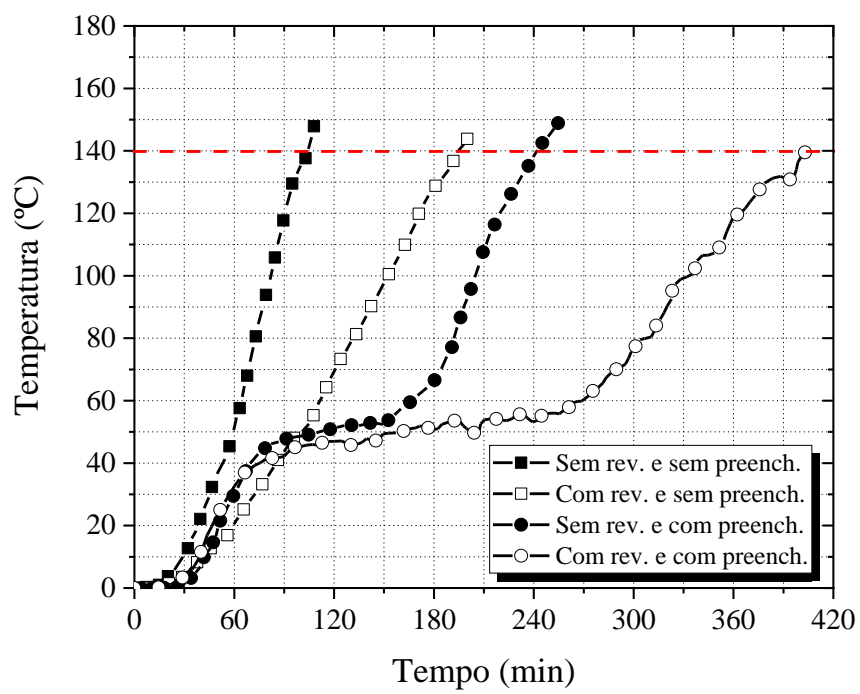

Fonte: Adaptada de Rosemann (2011).

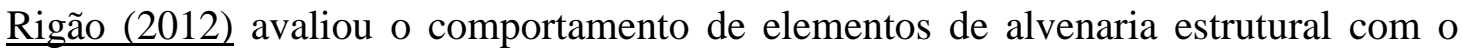
objetivo de verificar o nível de degradação dos materiais, a resistência residual de prismas e pequenas paredes de alvenaria e o aumento de carga nas pequenas paredes devido à elevação de temperatura. Para isso, foram confeccionados prismas de dois blocos e pequenas paredes com 90 x $100 \mathrm{~cm}$ utilizando blocos cerâmicos estruturais com $14 \mathrm{~cm}$ de espessura, $29 \mathrm{~cm}$ de comprimento e argamassa de assentamento industrializada com resistência nominal igual $4 \mathrm{MPa}$.

Os prismas foram submetidos a temperaturas de $400{ }^{\circ} \mathrm{C}$ e $900{ }^{\circ} \mathrm{C}$ durante 30 minutos, e sofreram ruptura após 48 e 24 horas de resfriamento no forno para cada situação, respectivamente. As pequenas paredes submeteram-se ao ensaio em temperaturas elevadas por um período de seis horas, sendo aquecidas em uma única face após 28 dias de cura, e com um carregamento de $78 \mathrm{kN} / \mathrm{m}$ aplicado por um macaco hidráulico restringindo o deslocamento vertical. Ambos os elementos foram ensaiados em um forno adaptado cuja elevação de temperatura no seu interior não foi capaz de simular a curva de incêndio-padrão, conforme apresentado na Figura 2.16.

Os prismas ensaiados em temperatura ambiente obtiveram resistência média à compressão de 5,30 MPa e apresentaram resistência residual de 73\% e 48,7\% quando submetidos a $400{ }^{\circ} \mathrm{C}$ e $900{ }^{\circ} \mathrm{C}$, respectivamente. Após 24 horas da realização dos ensaios, as pequenas paredes foram rompidas a uma tensão de ruptura de 2,58 MPa para a área bruta. Este valor foi $31,6 \%$ menor que aquele verificado em temperatura ambiente. Durante a realização dos ensaios notou-se um considerável aumento no carregamento que as paredes 
estavam submetidas em decorrência da impossibilidade de movimentação devido à expansão térmica do elemento estrutural.

Figura 2.16 - Vista geral do forno e da pequena parede antes do ensaio
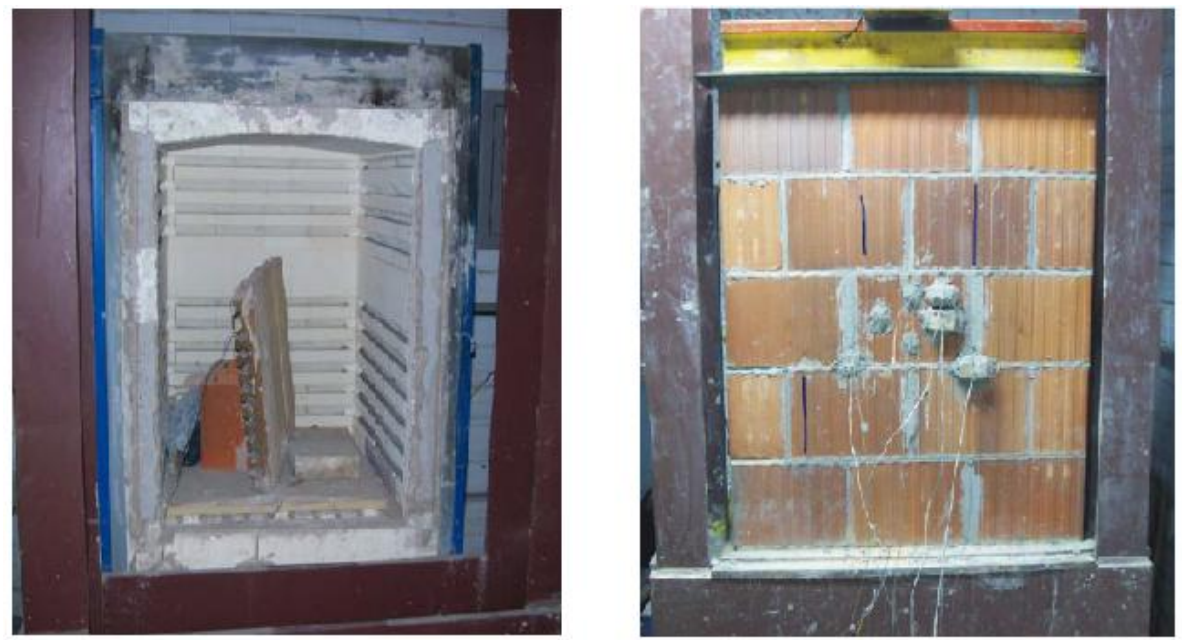

Fonte: Adaptada de Rigão (2012).

Os elementos apresentaram boa estanqueidade, sem a passagem de gases, e um baixo nível de fissuração, com a maioria destas na face exposta ao fogo. Através de seis termopares distribuídos sobre a seção transversal das pequenas paredes foi possível verificar a variação do gradiente térmico e observou-se que o critério de isolamento térmico foi atingido entre 223 e 268 minutos.

No mesmo estudo, realizou-se uma avaliação acerca do desempenho mecânico de argamassas industrializadas quando submetidas à situação de incêndio. Para isso, foram

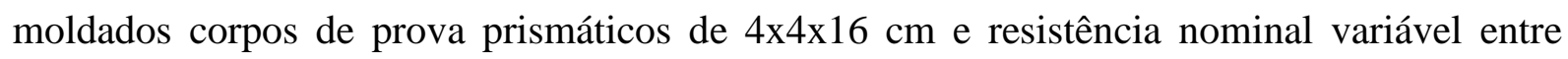
$4 \mathrm{MPa}$ e $12 \mathrm{MPa}$. Três corpos de prova de cada lote, após 28 dias de cura, foram ensaiados em temperatura ambiente e submetidos a temperaturas de $400{ }^{\circ} \mathrm{C}$ e $900{ }^{\circ} \mathrm{C}$.

As argamassas aquecidas foram ensaiadas dois dias após resfriamento em temperatura ambiente. As argamassas submetidas a temperatura de $400{ }^{\circ} \mathrm{C}$ não apresentaram degradação visível após o ensaio e obtiveram-se resistências residuais de 39\% para tração e 56,6\% para compressão. As argamassas sujeitas a $900{ }^{\circ} \mathrm{C}$ não apresentaram resistência significativa, sendo evidente o comportamento enfraquecido do material, impedindo o manuseio sem que houvesse a completa deterioração do corpo de prova.

De maneira similar ao estudo apresentado anteriormente, inclusive com experimentação realizada no mesmo Laboratório de Materiais de Construção Civil da Universidade Federal de Santa Maria (UFSM), Cocco (2014) realizou análise do tempo de resistência ao fogo de pequenas paredes de alvenaria estrutural submetidas à situação de 
incêndio. Os painéis foram constituídos de blocos cerâmicos estruturais com dimensões 14x19x29 cm e resistência nominal à compressão de $15 \mathrm{MPa}$, ensaiados sob carga em serviço de $100 \mathrm{kN}$.

Foram avaliadas seis corpos de prova de painéis cerâmicos com $74 \mathrm{~cm}$ de largura e 79 $\mathrm{cm}$ de altura, construídos com argamassa de assentamento industrializada com resistência nominal de $10 \mathrm{MPa}$, revestidos com argamassa industrializada de 2,0 cm de espessura na face exposta e 1,5 cm na face não exposta ao fogo. Analisaram-se dois protótipos preenchidos com graute de resistência característica à compressão $\left(\mathrm{f}_{\mathrm{ck}}\right)$ de $25 \mathrm{MPa}$, e outros dois painéis tiveram seus vazios ocupados com areia de granulometria média a fina.

As pequenas paredes foram ensaiadas durante 240 minutos em um forno adaptado cuja taxa média de elevação de temperatura foi de $20{ }^{\circ} \mathrm{C} / \mathrm{min}$, programado para que esta se mantivesse constante após atingir a temperatura de $900{ }^{\circ} \mathrm{C}$. A medição de temperatura na face não exposta ao fogo foi realizada através de uma câmera termográfica de alta resolução, capaz de medir variações de temperatura de $-20{ }^{\circ} \mathrm{C}$ a $1220{ }^{\circ} \mathrm{C}$, que captou as imagens termográficas com intervalos de 30 minutos para cada situação.

Através do espectro de variação de temperatura, avaliaram-se os tempos de resistência ao fogo dos painéis estruturais analisados. Em ambas as situações, nenhum ponto da face não exposta ao fogo apresentou temperatura superior a $180{ }^{\circ} \mathrm{C}$, sendo este o limite normatizado nos códigos brasileiros para atendimento ao critério de isolamento térmico. No entanto, como a elevação de temperatura no interior do forno não seguiu a curva de incêndio-padrão, este critério não pôde ser avaliado.

Os painéis de alvenaria estrutural sem preenchimento apresentaram temperatura média $51,5 \%$ e $61 \%$ superior aos painéis grauteados e preenchidos com areia, respectivamente. Comparando os painéis preenchidos, verificou-se que aqueles com areia apresentaram um desempenho térmico superior ao final do ensaio, destacando esse material como sendo uma alternativa viável e de baixo custo para utilização em paredes corta fogo.

Segundo a autora, todos os painéis apresentaram bom comportamento quanto à estanqueidade e baixo nível de fissuração na face não exposta. Na face interna de todos os painéis foi possível verificar o fenômeno da mudança de tonalidade e calcinação do revestimento argamassado. Na Figura 2.17 são apresentadas as imagens termográficas obtidas após 240 minutos de ensaios em elevadas temperaturas correspondente apenas a um dos protótipos ensaiados para cada situação, e a superfície exposta de um dos painéis após o ensaio, destacando que essa configuração também foi observada nos demais. 
Figura 2.17 - Análise térmica aos 240 minutos dos painéis (a) sem preenchimento, (b) grauteados, (c) preenchidos com areia e (d) superfície exposta após o ensaio

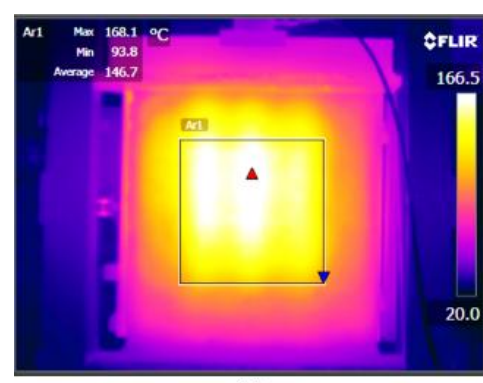

(a)

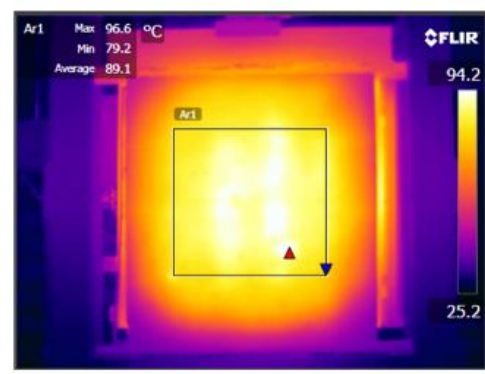

(c)

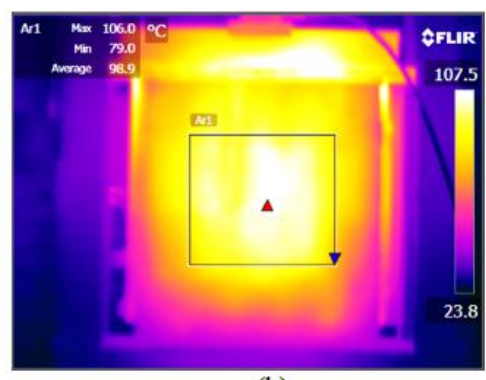

(b)

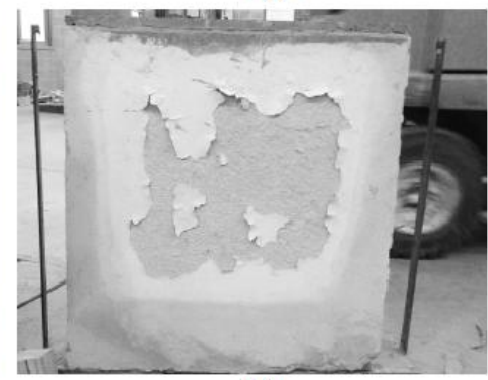

(d)

Fonte: Adaptada de Cocco (2014).

Em Menegon (2017) foi realizado um estudo experimental através da captação de imagens térmicas que possibilitaram a obtenção da diferença de propagação de calor em pequenas paredes de alvenaria estrutural para diferentes tipos de blocos cerâmicos utilizando a técnica não destrutiva da termografia infravermelha.

Para realização do estudo, foram confeccionadas pequenas paredes de alvenaria estrutural com dimensões 90x80 cm, utilizando dois tipos de bloco cerâmicos com paredes vazadas de mesma resistência nominal à compressão (7 MPa) e com espessura de $14 \mathrm{~cm}$ e 19 $\mathrm{cm}$. As pequenas paredes não foram revestidas, e a argamassa de assentamento industrial utilizada possuía resistência à compressão de $4 \mathrm{MPa}$.

Após 60 dias, as pequenas paredes foram submetidas a ensaio realizado em um forno de pequenas dimensões cuja elevação de temperatura seguiu a curva de incêndio-padrão recomendada pelo ISO 834-1:1999 até atingir a temperatura de $900{ }^{\circ} \mathrm{C}$, onde o acréscimo de temperatura foi interrompido e mantido constante por quatro horas. Os protótipos foram ensaiados sob um carregamento em serviço de $90 \mathrm{kN}$ e tiveram apenas uma das faces exposta ao fogo.

O monitoramento do ensaio foi realizado de maneira contínua e o comportamento térmico da face não exposta ao fogo foi avaliado a partir de imagens captadas em cada instante para os dois tipos de blocos utilizados. Observou-se que o aquecimento das pequenas paredes com $14 \mathrm{~cm}$ de espessura foi mais intenso até os 45 minutos, indicando uma maior 
transmissão de calor entre as duas faces nos blocos de menor espessura, mas que ao final do ensaio os dois tipos de blocos apresentaram desempenho semelhante quanto à elevação de temperatura na face não exposta, destacando a maior capacidade de isolamento dos blocos com espessura de $19 \mathrm{~cm}$ e que a partir de um nível de temperatura e tempo de exposição às chamas, todo o calor emitido já havia se propagado para a superfície externa através da espessura da parede, conforme a Figura 2.18.

Figura 2.18 - Termografia em blocos cerâmicos estruturais com espessura de $14 \mathrm{~cm}$ e $19 \mathrm{~cm}$

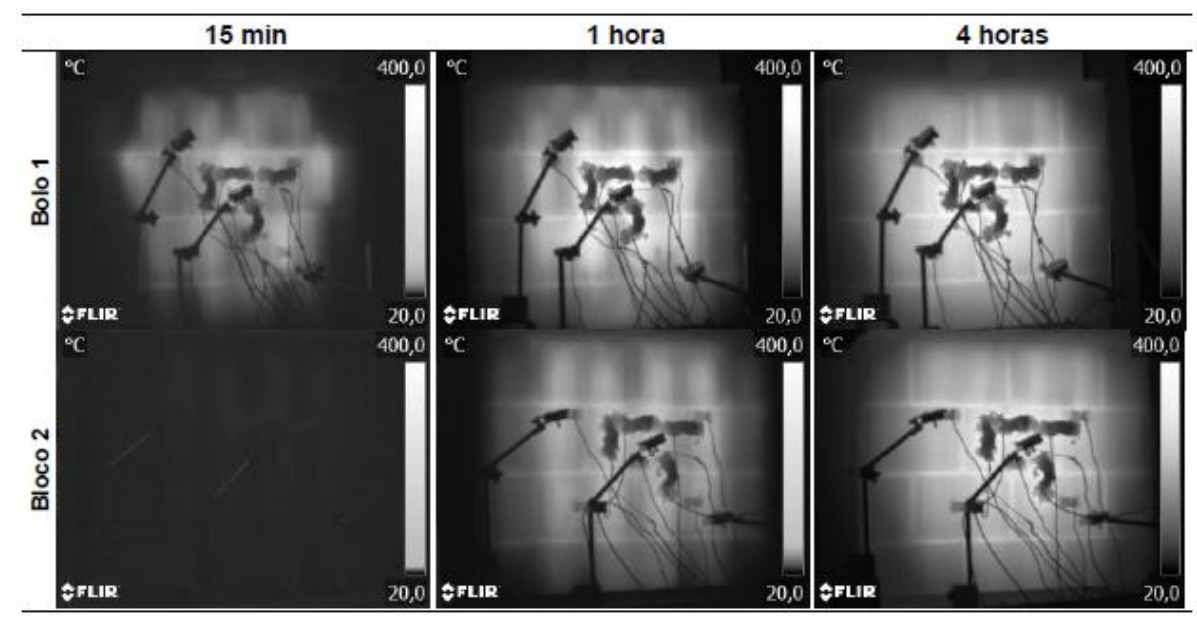

Fonte: Adaptada de Menegon (2017).

$\underline{\text { Souza (2017) }}$ realizou um estudo experimental com o objetivo de verificar quais os principais parâmetros que influenciam a resistência ao fogo dos elementos de alvenaria estrutural constituída de blocos cerâmicos com paredes vazadas, com dimensões 14x19x29 cm e resistência característica à compressão igual a 8,65 MPa. Dessa maneira, foram executadas paredes de alvenaria estrutural com 3,15 x 3,00 metros, assentadas sob pórticos metálicos para facilitar a sua movimentação até o forno vertical.

Foram confeccionadas seis tipos de paredes variando a espessura do revestimento interno (face exposta ao fogo) em 15 e $25 \mathrm{~mm}$ de espessura, assim como a presença ou não de carregamento aplicado de $10 \mathrm{tf} / \mathrm{m}$. A Tabela 2.6 indica as principais características dos corpos de prova analisados e a variação dos parâmetros avaliados.

Os ensaios realizados possibilitaram a avaliação dos critérios de isolamento térmico, estanqueidade e resistência mecânica dos protótipos. Os mesmos foram expostos à elevação de temperatura seguindo a curva de incêndio-padrão sugerida pela ISO 834-1:1999.

$\mathrm{O}$ autor concluiu que dentre as paredes sem carregamento, aquela que apresentou maior TRRF foi a parede P5, destacando a eficácia do aumento da espessura do revestimento. Este corpo de prova atendeu durante 240 minutos aos critérios de estanqueidade a gases e 
fumaça, estabilidade estrutural e isolamento térmico. Dentre as paredes carregadas, a P6 apresentou melhor desempenho, atingindo um TRRF de 221 minutos.

Tabela 2.6 - Características das amostras

\begin{tabular}{|c|c|c|c|c|c|}
\hline \multirow{2}{*}{$\begin{array}{l}\text { Corpo de } \\
\text { prova }\end{array}$} & \multicolumn{2}{|c|}{$\begin{array}{c}\text { Lado interno } \\
\text { (face exposta ao fogo) } \\
\end{array}$} & \multicolumn{2}{|c|}{$\begin{array}{c}\text { Lado externo } \\
\text { (face não exposta ao fogo) }\end{array}$} & \multirow{2}{*}{$\begin{array}{c}\text { Carregamento } \\
(\mathbf{t} \mathbf{f} / \mathbf{m})\end{array}$} \\
\hline & Chapisco & $\begin{array}{l}\text { Revestimento } \\
(\mathrm{mm})\end{array}$ & Chapisco & $\begin{array}{l}\text { Revestimento } \\
(\mathrm{mm})\end{array}$ & \\
\hline Parede P1 & Não & Não & Sim & 25 & Não \\
\hline Parede P2 & Não & Não & Sim & 25 & 10 \\
\hline Parede P3 & Sim & 15 & Sim & 25 & Não \\
\hline Parede P4 & Sim & 15 & Sim & 25 & 10 \\
\hline Parede P5 & Sim & 25 & Sim & 25 & Não \\
\hline Parede P6 & Sim & 25 & Sim & 25 & 10 \\
\hline
\end{tabular}

Fonte: Adaptada de Souza (2017).

O autor esclarece que a utilização do revestimento interno possibilitou uma redução de até 46,3\% na temperatura da face não exposta ao fogo. Quanto aos impactos da aplicação de carregamento, as paredes não carregadas apresentaram maior deslocamento fora do plano, devido à falta de restrição nas faces superior e inferior. A redução nos deslocamentos horizontais nas paredes carregadas foi de até $58,1 \%$ quando as mesmas possuíam uma camada de revestimento interno igual a $15 \mathrm{~mm}$.

Destaca-se ainda que durante a realização dos ensaios nas paredes de alvenaria estrutural com aplicação de carregamento, observou-se o fenômeno do lascamento dos blocos cerâmicos da face exposta ao fogo, atribuído à incidência do efeito de $2^{\circ}$ ordem devido às excentricidades da parede, comprometendo a estabilidade estrutural do elemento, conforme apresenta a Figura 2.19.

Figura 2.19 - Lascamento em parede de alvenaria estrutural com blocos cerâmicos

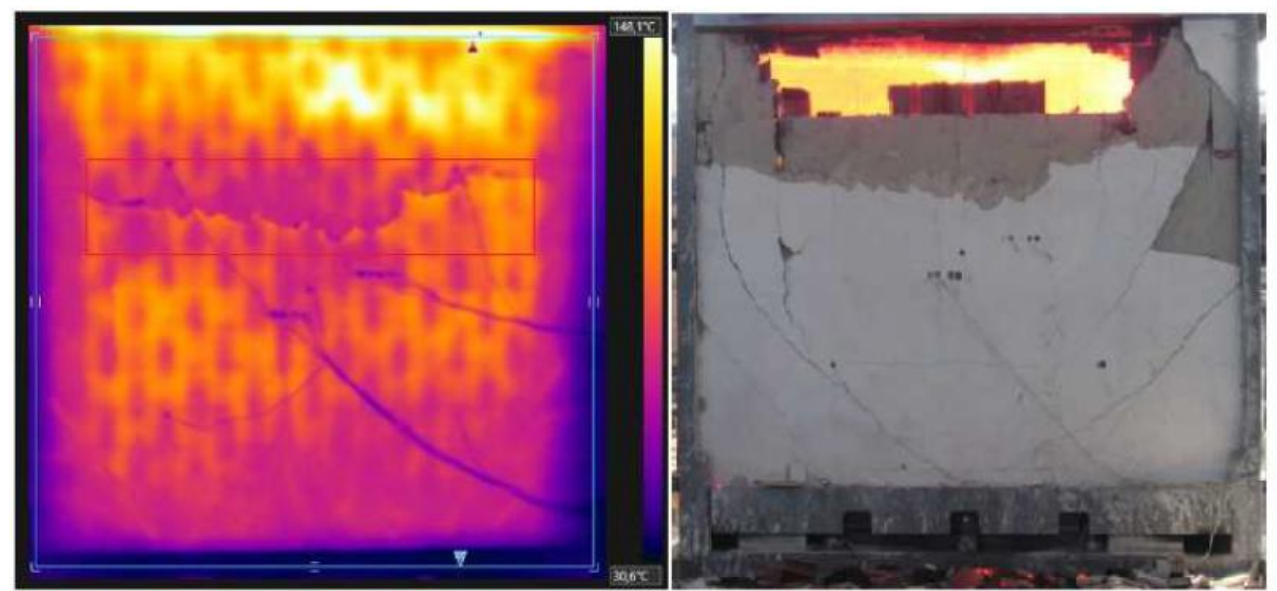

Fonte: Souza (2017). 


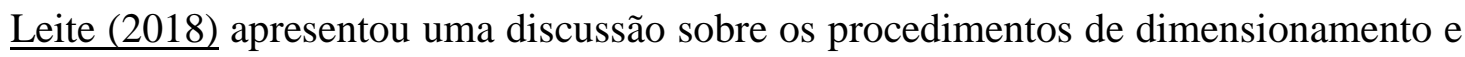
verificação de elementos de alvenaria estrutural submetidos à situação de incêndio, baseandose em cinco normas internacionais que tratam sobre o assunto. A partir dos códigos sulafricano, americano, australiano, neozelandês e europeu, descreveram-se os principais critérios e especificações adotadas pelos respectivos códigos com o objetivo de contribuir para futuras discussões acerca da elaboração de uma normatização nacional sobre o assunto.

Desta maneira, tomando como referência o tempo requerido de resistência ao fogo (TRRF) de 120 minutos, avaliou-se o desempenho de 15 diferentes blocos de concreto usualmente utilizados no Brasil, conforme variação da espessura, comprimento e classe de resistência dos blocos, afim de verificar o atendimento dos mesmos aos critérios estabelecidos pelos códigos internacionais abordados no trabalho.

A autora destaca o caráter conservador do código sul-africano, com parâmetros indicados para análise de blocos maciços de alvenaria, em geral, não usuais no Brasil. Quanto ao código americano, este leva em consideração apenas o isolamento térmico dos elementos, desprezando o nível de carregamento mecânico nas paredes, assim, apenas dois blocos atenderam aos critérios especificados por este código.

Constatou-se que o tempo de resistência ao fogo obtido através do critério de isolamento adotado pelas normas americana, australiana e neozelandesa são compatíveis entre si e não foram atendidos pelos blocos avaliados. Para análise do critério de resistência mecânica do código australiano, consideraram-se paredes estruturais com 3,0 x 3,0 metros com os diferentes blocos, e verificou-se com base no nível de esbeltez do elemento estrutural, que 12 tipos de blocos satisfaziam os limites estabelecidos.

Finalmente, o trabalho destaca o código europeu como sendo o mais recomendado para utilização e adequação à prática brasileira, tendo em vista a possibilidade de avaliação segundo os critérios de resistência, estanqueidade e isolamento térmico, além de apresentar um cunho menos conservador, o que possibilitou que diferentes tipos de blocos com níveis de carregamento até $60 \%$ das solicitações usuais em situação ambiente, superassem o TRRF de 120 minutos.

Sob outra perspectiva, uma análise numérica foi realizada para avaliar o desempenho térmico de blocos de concreto com 19x19x39 cm para diferentes tipos de agregados. Os blocos foram submetidos a uma elevação de temperatura em apenas uma das faces durante quatro horas, seguindo a curva de incêndio-padrão da ISO 834-1:1999. Os vazios dos blocos foram simulados como um fluido representando a massa de ar e a ligação entre o bloco e o vazio presente no bloco foi considerada através de mecanismos de interação fluido-estrutura. 
Tomando como base o critério de isolamento térmico, observou-se que os blocos com agregados de basalto e granito não apresentaram problemas quanto ao critério térmico, porém, os blocos compostos com agregados de calcário falharam aos 221 minutos de análise, enfatizando que a alteração da condutividade térmica do bloco através do tipo de agregado, pode influenciar no desempenho térmico e resistência ao fogo da alvenaria.

Lima et al. (2018) avaliaram o comportamento mecânico de pequenas paredes de alvenaria estrutural com blocos cerâmicos submetidos a uma elevação de temperatura. Foram utilizados quatro diferentes tipos de bloco cerâmico com resistência à compressão de $7,10,15$ e $18 \mathrm{MPa}$ (Figura 2.20) executados utilizando argamassas de 6, 8, 10 e $12 \mathrm{MPa}$, respectivamente.

Figura 2.20 - Blocos cerâmicos de alvenaria estrutural utilizados no estudo

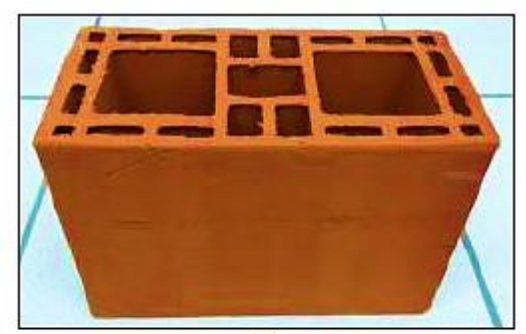

(a)

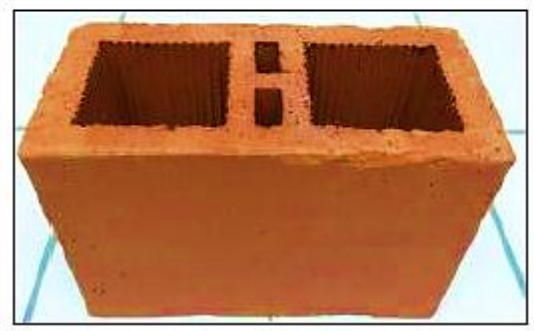

(c)

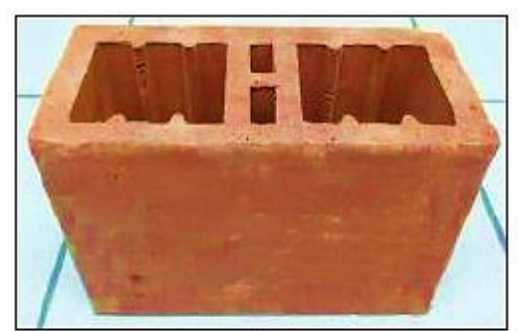

(b)

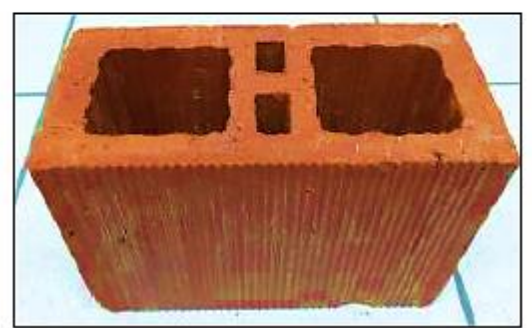

(d)

Fonte: Lima et al. (2018).

As paredes possuíam $75 \mathrm{~cm}$ de comprimento e $80 \mathrm{~cm}$ de altura, e sujeitaram-se à aplicação de um carregamento em serviço de 85, 120, 185 e $220 \mathrm{kN}$ para os blocos a, b, c e d, respectivamente. Ambas foram ensaiadas com uma das faces submetidas à elevação de temperatura, acoplada ao forno vertical com uma temperatura constante de $900{ }^{\circ} \mathrm{C}$ durante quatro horas de exposição, simultaneamente com a aplicação do carregamento.

De acordo com os resultados obtidos, os autores destacam maior capacidade isolante no bloco com paredes vazadas (a), devido à presença de vazios nas suas paredes e septos transversais que reduzem a transmissão térmica de calor, sendo o bloco (b) aquele que apresentou o pior desempenho quanto ao isolamento térmico. Quanto aos demais componentes utilizados com geometria similar e diferentes classes de resistência, os blocos 
com maior resistência mecânica proporcionaram maior isolamento térmico.

No tocante à capacidade portante dos painéis de alvenaria testados, nenhum deles apresentou deslocamentos excessivos que pudessem causar o colapso estrutural. Acrescentase ainda em todos os testes realizados, percebeu-se um destacamento do revestimento interno aplicado na face exposta ao fogo, grande deterioração da argamassa de assentamento e fissuração nos blocos das pequenas paredes, conforme a Figura 2.21.

Figura 2.21 - Fissuração nos diferentes tipos de blocos

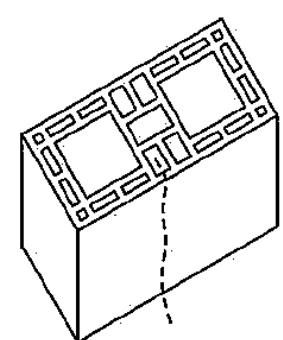

(a)

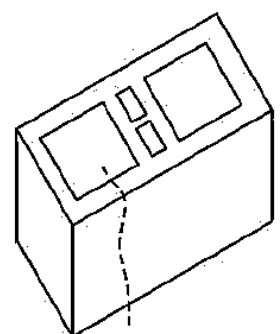

(c)

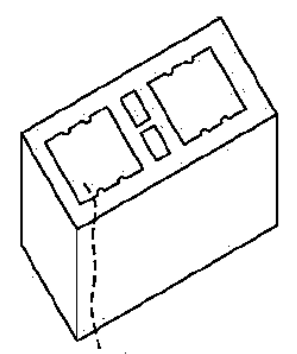

(b)

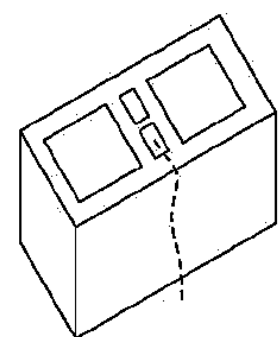

(d)

Fonte: Lima et al. (2018).

$\underline{\text { Rodovalho (2018) }}$ realizou uma avaliação numérica do comportamento de prismas e blocos de alvenaria estrutural com blocos cerâmicos e de concreto através do software Abaqus, a fim de verificar o desempenho da alvenaria estrutural quando submetida a elevadas temperaturas.

No desenvolvimento das simulações térmicas a autora analisou o desempenho dos elementos quanto ao critério de isolamento considerando a contribuição de revestimento em argamassa convencional e verificou que o bloco cerâmico possui uma maior capacidade de isolamento térmico que o bloco de concreto, além de uma considerável influência favorável ao isolamento térmico quando há uma aplicação de revestimentos em argamassa em ambas as faces destes elementos.

Os prismas com blocos cerâmicos apresentaram isolamento térmico de até 105 minutos, e obtiveram aumento considerável de $89 \%$ para os mesmos elementos com uma camada de revestimento em argamassa usual com 1,5 cm de espessura em ambas as faces. Em comparação com os prismas utilizando blocos de concreto, o acréscimo foi de $22 \%$ para os 
prismas cerâmicos sem revestimento, e mais de $45 \%$ para os elementos revestidos em ambas as faces.

Quanto ao comportamento mecânico foi possível notar que a restrição dos deslocamentos verticais antecipa a ruptura do prisma, e que a falta de restrição rotacional nos elementos ocasiona o surgimento de tensões de tração na face exposta ao ambiente, gerando um modo de ruptura diferente e em um tempo inferior de resistência ao fogo.

\subsubsection{Pesquisas no âmbito internacional}

Nadjai et al. (2006) realizaram uma série de estudos analíticos para investigar o comportamento de paredes de alvenaria estrutural suportando uma laje em concreto armado, mediante uma série de cenários de incêndio. Consideraram-se paredes de alvenaria estrutural com 3 metros de altura, sujeitas à elevação de temperatura em apenas uma das faces longitudinais, conforme apresentado na Figura 2.22.

Figura 2.22 - Subpartes da estrutura considerada para avaliação numérica
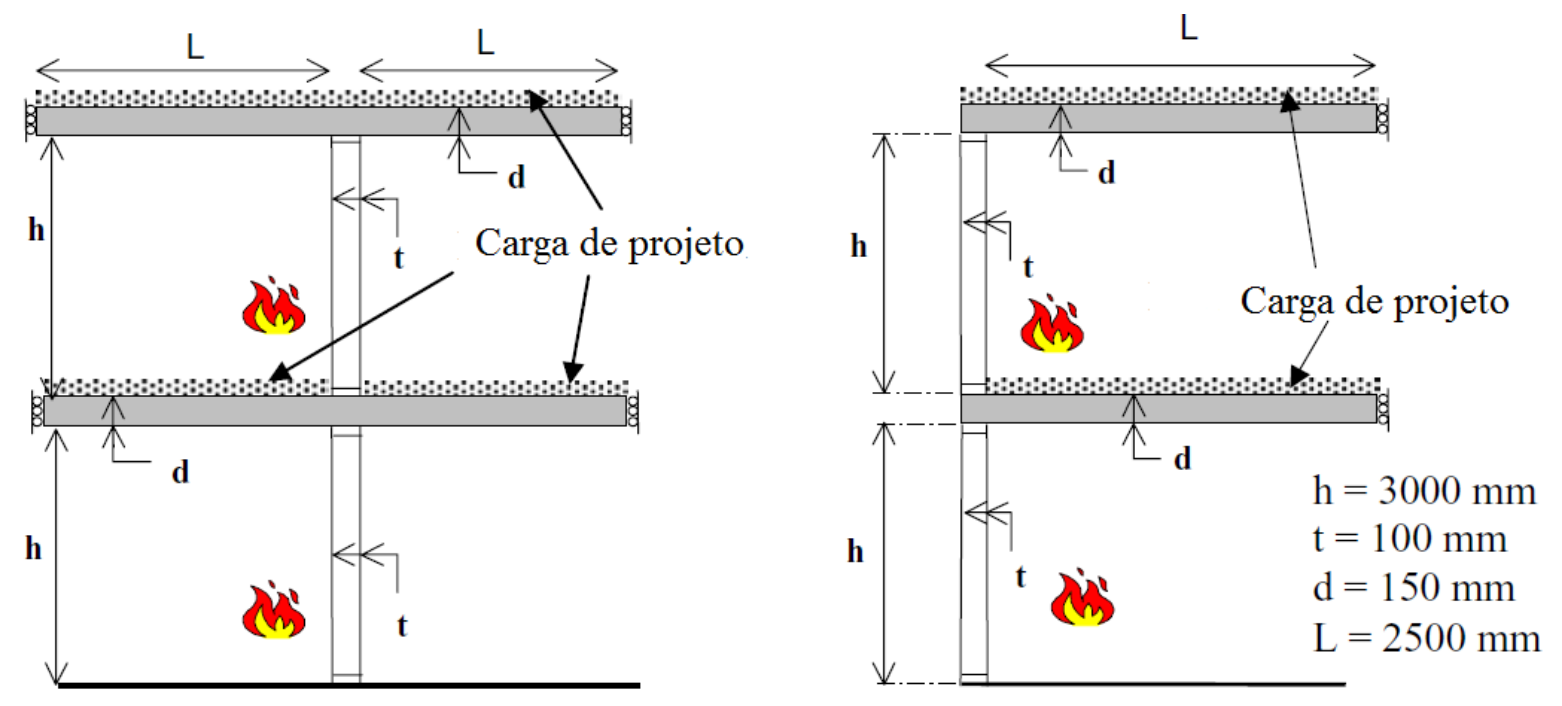

Fonte: Adaptada de Nadjai et al. (2006).

Para realização do estudo, os autores consideraram três diferentes situações de ação do incêndio, como a consideração do mesmo apenas no pavimento inferior, apenas no pavimento superior, ou ainda com ambos os pavimentos sujeitos à elevação de temperatura.

Como resultado das análises, os autores verificaram que os deslocamentos fora do plano de uma parede não são influenciados pela ocorrência de um incêndio em um compartimento vertical adjacente. Além disso, para ambos cenários de posicionamento do incêndio, os deslocamentos das paredes superiores mostraram-se mais elevado em relação aos 
das paredes inferiores, pelo fato de que estas estão sujeitas à níveis de tensões superiores, portanto, com maior restrição ao deslocamento, como pode ser visto na Figura 2.23.

Figura 2.23 - Deformação das paredes com incêndio em cenários distintos
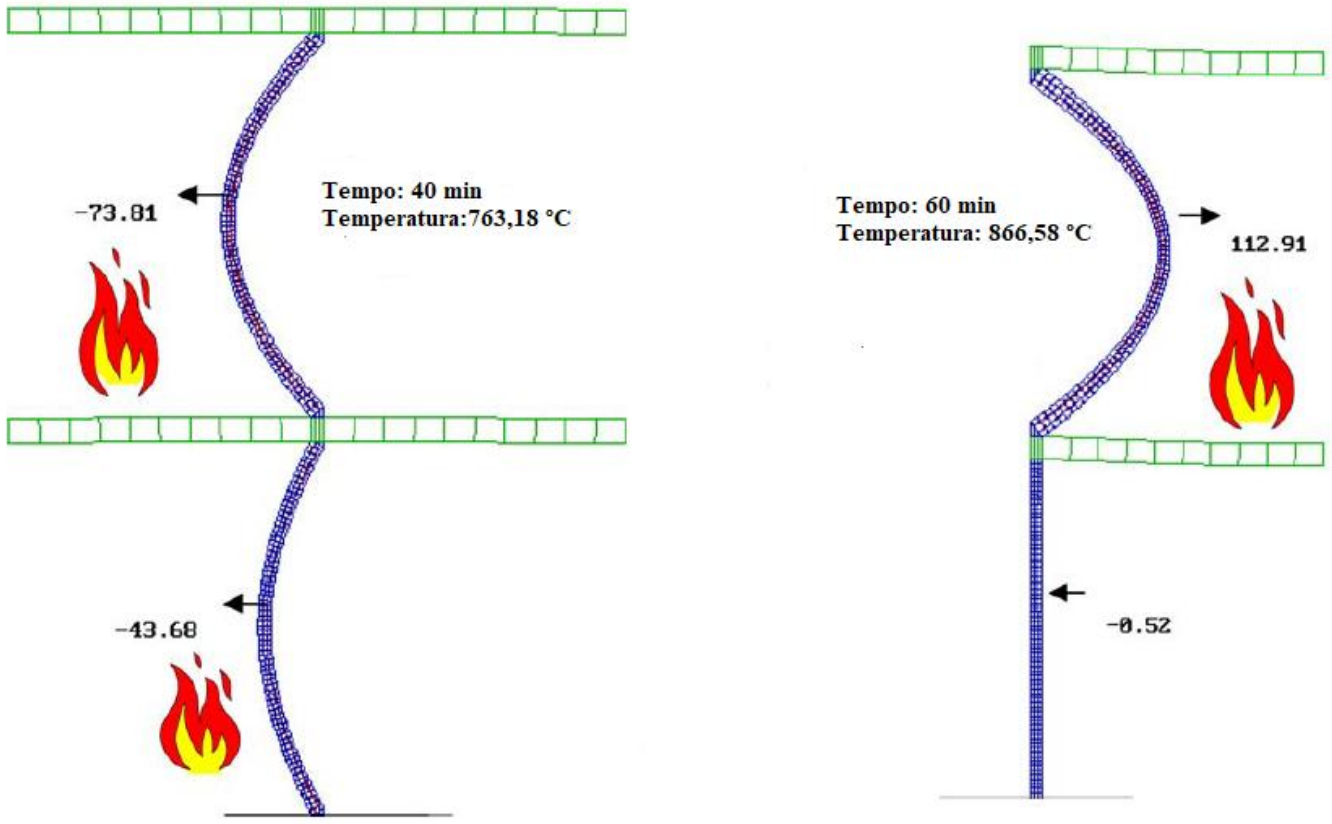

Fonte: Adaptada de Nadjai et al. (2006).

$\underline{\text { Ayala (2010) }}$ avaliou através de análises numéricas e ensaios experimentais o comportamento sob altas temperaturas de corpos de prova de argamassa, blocos maciços e pequenas paredes de alvenaria estrutural com tijolos de concreto leve. Inicialmente os corpos de prova foram expostos ao fogo sem nenhum tipo de carregamento, e apenas após o equilíbrio térmico dos mesmos inseriu-se de maneira gradual a aplicação do carregamento até sua ruptura.

As pequenas paredes de alvenaria estrutural com dimensões de $68,5 \mathrm{~cm}$ de comprimento, $67 \mathrm{~cm}$ de altura e $10 \mathrm{~cm}$ de espessura, foram aquecidas a 200, 400, 600, $700 \mathrm{e}$ $800{ }^{\circ} \mathrm{C}$, com incrementos de $10{ }^{\circ} \mathrm{C} / \mathrm{min}$, com posterior aplicação de carregamento a uma taxa de 10 kN/min até a ruína, conforme a Figura 2.24.

Nas pequenas paredes o autor observou uma redução na resistência à compressão que variaram de $9 \%$ quando os elementos foram submetidos a $400{ }^{\circ} \mathrm{C}$, até $83 \%$ quando os mesmos estavam sujeitos a temperaturas de $800^{\circ} \mathrm{C}$. Na ruptura das pequenas paredes em situação de incêndio houve o surgimento de fissuras na direção diagonal, além do fenômeno do lascamento que se tornou mais expressivo com o aumento de temperatura acima dos $400{ }^{\circ} \mathrm{C}$. Além disso, quanto ao módulo de elasticidade das pequenas paredes, este foi reduzido até a ordem de $98 \%$ quando os elementos estiveram sujeitos a $800^{\circ} \mathrm{C}$. 
Figura 2.24 - Pequena parede de alvenaria estrutural sob teste de compressão antes da elevação de temperatura

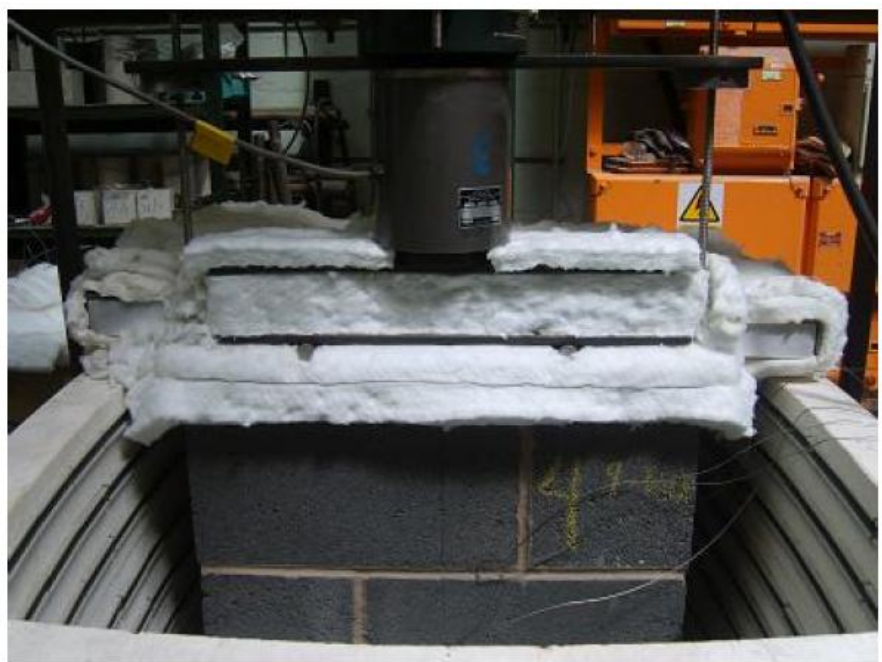

Fonte: Ayala (2010).

Para os blocos maciços de concreto leve, Ayala (2010) relatou que também houve considerável redução da resistência à compressão da ordem de $28 \%$ a $200{ }^{\circ} \mathrm{C}$, e de até $65 \%$ quando os corpos de prova estiveram perante temperaturas de $800{ }^{\circ} \mathrm{C}$.

Em estudo elaborado por Nguyen e Meftah (2012) foram apresentados quatro ensaios representativos de paredes de alvenaria estrutural com blocos cerâmicos em situação de incêndio com objetivo de analisar os principais efeitos térmicos e o comportamento mecânico destas paredes, variando entre elas a espessura, o tipo de bloco utilizado e o nível de carregamento aplicado.

Avaliaram-se paredes com espessuras de $10 \mathrm{~cm}$ e $20 \mathrm{~cm}$, além de paredes carregadas com taxas de carregamento de $90 \mathrm{kN} / \mathrm{m}$ e $130 \mathrm{kN} / \mathrm{m}$, expostas à elevação de temperatura em apenas uma das faces em um forno vertical. Durante o processo de execução dos corpos de prova, as paredes descarregadas tiveram os blocos de alvenaria com furos orientados na direção horizontal, e as paredes carregadas apresentavam furos na vertical.

Os autores observaram que após a realização do programa experimental, as paredes que foram ensaiadas sem aplicação de carregamento não apresentaram instabilidade estrutural, sendo a resistência ao fogo destas paredes controladas pelo critério de isolamento térmico e quando as espessuras dos elementos excederam um limite de 12 a $14 \mathrm{~cm}$ houve uma maior deterioração da face exposta ao fogo com lascamento e fragmentação dessa superfície. As paredes carregadas perderam estabilidade devido ao lascamento e fragmentação localizada, que por sua vez, se propagou em toda a espessura da parede, assim, houve um aumento nos momentos fletores de flexão que surgiram devido à indução do lascamento por 
conta da excentricidade das cargas verticais aplicadas (Figura 2.25)

Figura 2.25 - Fenômeno do lascamento em paredes de alvenaria sem carregamento e carregadas
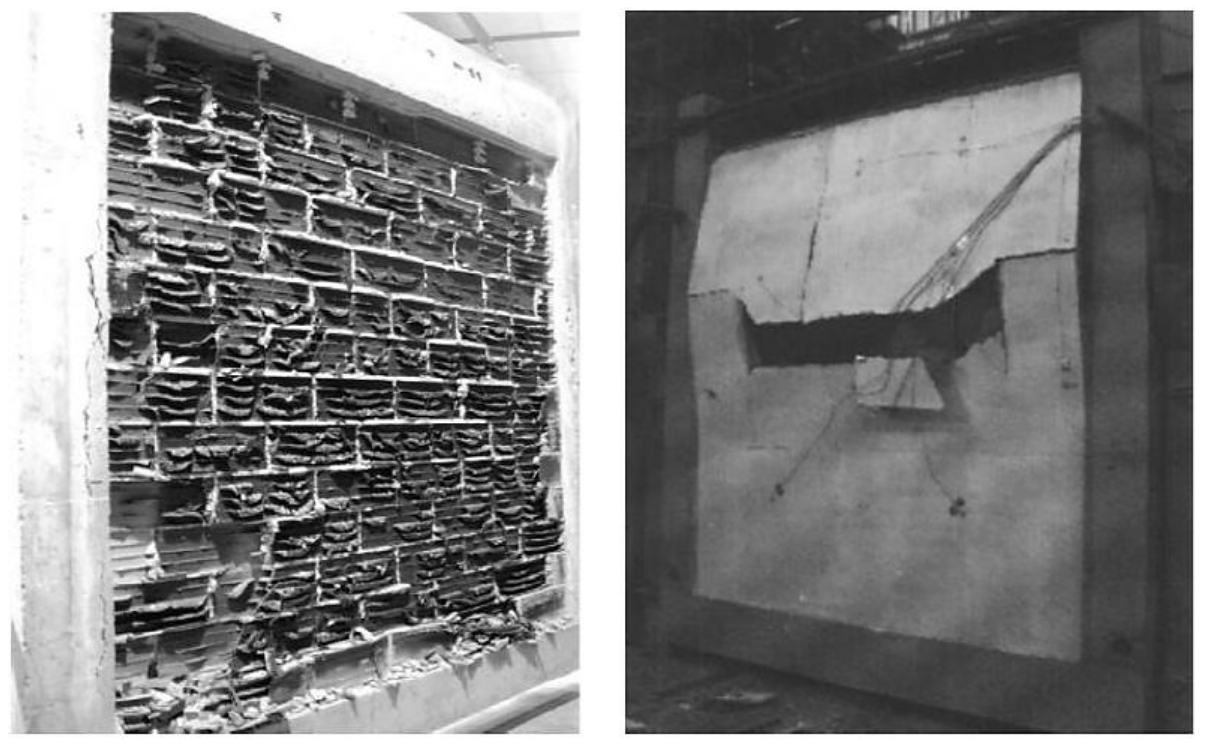

Fonte: Adaptada de Nguyen e Meftah (2012).

As paredes descarregadas apresentaram isolamento térmico de 43 minutos para aquelas de espessura igual a $10 \mathrm{~cm}$, e 104 minutos para as paredes com espessura de $20 \mathrm{~cm}$. Quanto aos deslocamentos horizontais na região central da face exposta ao fogo, as paredes com $10 \mathrm{~cm}$ de espessura exibiram deslocamentos da ordem de $67 \%$ superiores em relação às paredes com o dobro da espessura.

A partir da análise da medição de temperatura na seção transversal dos blocos, os autores concluíram que o fluxo de calor direcionado através dos furos dos blocos é maior que aquele transferido por condução através dos septos transversais.

Nguyen e Meftah (2014) analisaram numericamente os mesmos modelos que haviam sido ensaiados experimentalmente dois anos anteriores, com o objetivo de realizar uma abordagem teórica através da utilização dos elementos finitos para investigar o desempenho e o comportamento desses elementos sob a exposição do fogo, sobretudo dos elementos que se sujeitaram ao fenômeno do spalling ou lascamento brusco da seção transversal do elemento estrutural.

Dessa maneira, o modelo teórico proposto avalia as tensões atuantes nos septos dos blocos de alvenaria quando estes estão submetidos à ação do fogo. Caso essas tensões ultrapassem as tensões limitadas pela resistência do material, automaticamente o modelo remove a camada deteriorada e a superfície de exposição ao fogo passa a ser imediatamente o septo seguinte, de acordo com o apresentado na Figura 2.26. 
Figura 2.26 - Componentes de tensão nos septos de blocos de alvenaria sob ação do fogo

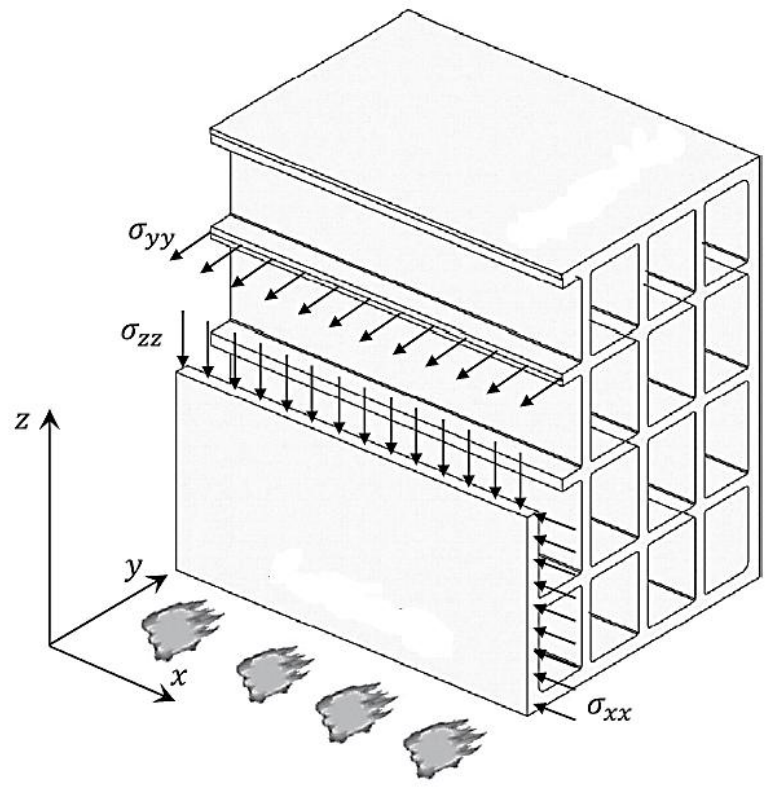

Fonte: Adaptada de Nguyen e Meftah (2014).

Os autores concluíram que o modelo representou bem o fenômeno do lascamento explosivo nos blocos cerâmicos de alvenaria, sobretudo na avaliação do comportamento térmico e mecânico, onde apresentou bons resultados para a deslocabilidade central dos painéis de alvenaria, e distribuição de temperatura na seção dos elementos estruturais.

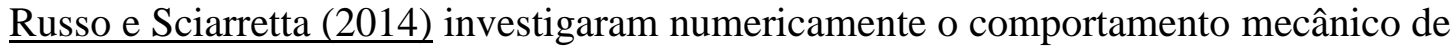
paredes de alvenaria com blocos cerâmicos após as mesmas serem submetidas à ação do incêndio imposta com o desenvolvimento de temperatura segundo a ISO 834-1:1999, com o objetivo de estabelecer relações entre a resistência dos elementos e a perca das propriedades mecânicas dos mesmos após a exposição ao incêndio.

Os autores analisaram paredes com espessura de 12, 25, 38 e $51 \mathrm{~cm}$, que foram simuladas no software Diana simulando um teste padrão de resistência ao fogo, e admitiram que o comportamento de fissuração das paredes sob exposição ao fogo foi satisfatoriamente representado pelos modelos, obtendo a maior redução na resistência à compressão de $49 \%$ naquelas paredes de $25 \mathrm{~cm}$, que embora não tenha sofrido a exposição ao fogo mais severa, mostrou-se como referente à combinação mais desfavorável entre espessura e tempo de exposição ao fogo. Observou-se também que as duas paredes mais espessas não obtiveram grandes reduções nas resistências, e os autores atribuíram isto ao fato de que as duas paredes já possuíam uma espessura significativa, e que em ambos os casos não apresentaram grande danificação do material em relação à espessura. 
Em Lopes et al. (2018) foi apresentado um estudo para avaliação da capacidade de carga a temperaturas elevadas e resistência ao fogo de paredes de alvenaria estrutural com blocos de concreto de três células, com dimensões de 1,0 x 1,40 x 0,10 m que foram ensaiadas em escala reduzida de 1:2.

Durante a aplicação do carregamento, foi destacado o surgimento de fissuras verticais na região central dos blocos, coincidente com a célula de menor dimensão nos mesmos, além de fissuras horizontais na interface entre bloco e junta de argamassa, e de fissuras diagonais que iniciaram nos cantos dos corpos de prova e se propagaram para a região central das paredes.

Os autores notaram um bom isolamento térmico durante os primeiros 67 minutos, e que em face dos resultados obtidos para os corpos de prova em escala natural, estes garantiriam facilmente uma resistência ao fogo de 90 minutos, muito superior ao previsto pelo Eurocode 6 Part 1-2:1996, concluindo acima de tudo que os critérios recomendados pela referida norma são demasiadamente conservadores.

\subsection{RESUMO DO CAPÍTULO}

Neste capítulo foram descritos as principais considerações sobre os sistemas de alvenaria estrutural, assim como sobre os principais conceitos atrelados ao comportamento das estruturas em situação de incêndio, além de uma breve apresentação de algumas pesquisas científicas desenvolvidas no Brasil e no exterior a respeito dos elementos de alvenaria estrutural em situação de incêndio.

Inicialmente, apresentou-se uma contextualização histórica dos sistemas em alvenaria estrutural, descrevendo seu desenvolvimento no país, com as principais características e textos normativos que atualmente embasam os projetos e a pesquisa neste sistema. Os principais materiais utilizados na construção de elementos de alvenaria não armados também foram descritos, destacando os principais detalhes quanto à fabricação, utilização e variabilidade dos blocos cerâmicos estruturais, além das principais características das argamassas de assentamento, como as especificações de traço para argamassas de cimento, cal e areia, forma de aplicação e resistências características à tração e flexão recomendadas pela ABNT NBR 15812:2010.

O comportamento mecânico da alvenaria foi apresentado conforme as características de resistência à compressão e módulo de elasticidade, enfatizando a maior eficiência prisma/bloco e parede/bloco dos elementos de alvenaria com blocos de concreto, assim como 
algumas correlações apresentadas para obtenção do módulo de elasticidade da alvenaria conforme resistência das unidades e da argamassa de assentamento.

Os principais conceitos ligados à ação do incêndio nas estruturas foram apresentados em seguida, indicando que a alta ocorrência de incêndios mundiais em edificações e a ocorrência de acidentes catastróficos despertaram o desenvolvimento de códigos normativos e pesquisas acerca do comportamento dos elementos estruturais quando sujeitos à ação do fogo. O fenômeno do incêndio foi descrito como um processo de combustão rápida, cuja elevação de temperatura no tempo foi representada através de três modelos de incêndio, destacando a curva de incêndio-padrão proposta pela ISO 834-1:1999.

Os mecanismos de transferência de calor foram apresentados conforme suas respectivas definições indicadas no contexto científico e ocorrência em diferentes meios e materiais. Além disso, o conceito de Tempo Requerido de Resistência ao Fogo (TRRF) foi exposto apresentando as recomendações da ABNT NBR 14432:2001, Eurocode 1 Part 12:2002 e da Instrução Técnica IT-08 (2018) do Corpo de Bombeiros do Estado de São Paulo.

Por fim, apresentou-se a descrição alguns trabalhos desenvolvidos no Brasil e no âmbito internacional a respeito dos elementos de alvenaria estrutural em situação de incêndio, destacando-se a realização de cunho experimental e numérico, objetivando avaliar a capacidade resistente dos elementos sujeitos à ação do fogo e verificar o desempenho térmico desses elementos. 


\section{PROGRAMA EXPERIMENTAL I: CARACTERIZAÇÃO DOS MATERIAIS E DA ALVENARIA ESTRUTURAL}

\subsection{CONSIDERAÇÕES INICIAIS}

Neste trabalho, o programa experimental constituiu de três etapas que foram desenvolvidas no Laboratório de Estruturas da Escola de Engenharia de São Carlos (LE EESC). Na primeira etapa foram realizados os ensaios de caracterização dos materiais e dos elementos de alvenaria estrutural. Na segunda e terceira etapa, respectivamente, foram realizados os ensaios de simulação de incêndio-padrão e testes mecânicos para avaliar o comportamento residual dos elementos de alvenaria sujeitos à situação de incêndio.

Neste capítulo foram descritas as principais etapas da caracterização em temperatura ambiente de todos os materiais empregados. As unidades cerâmicas foram avaliadas quanto às suas propriedades geométricas, físicas e mecânicas através de ensaios de compressão e tração indireta, e a alvenaria estrutural teve o seu comportamento verificado mediante ensaios de compressão em prismas e pequenas paredes. Além disso, também foram analisadas as principais propriedades das argamassas de assentamento e revestimento utilizadas.

\subsection{UNIDADES DE ALVENARIA ESTRUTURAL}

Nesta pesquisa foram utilizados blocos inteiros e meio-blocos de material cerâmico, ambos com espessura nominal de $140 \mathrm{~mm}$. No tocante às unidades, empregaram-se blocos cerâmicos com paredes vazadas e blocos cerâmicos com paredes maciças, sendo que, para estes últimos, as paredes internas eram vazadas, conforme a Figura 3.1.

Figura 3.1 - Blocos cerâmicos com paredes vazadas e paredes maciças
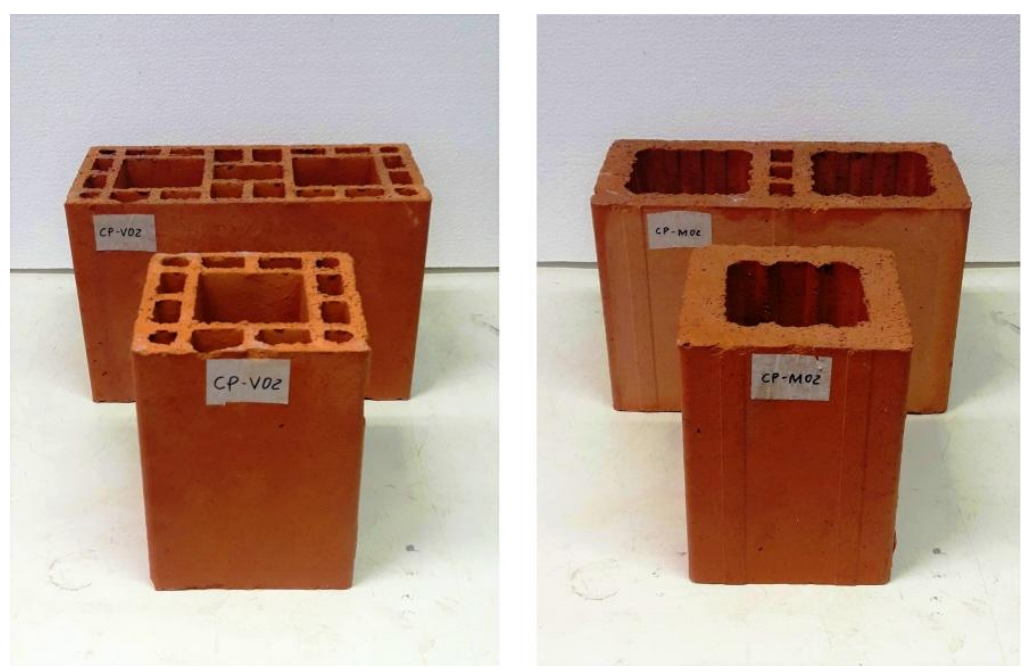

Fonte: Autor (2020). 
Todas as unidades foram fornecidas pela Cerâmica Palma de Ouro, e passaram pelo processo de inspeção visual no instante de recebimento para detecção de unidades com defeitos sistemáticos, como fissuras, superfícies irregulares e deformações excessivas que inviabilizariam a sua utilização, conforme recomendação da ABNT NBR 15270-1:2017.

Os blocos foram solicitados com resistência característica nominal à compressão de 8,0 MPa para as unidades com paredes vazadas, e 14,0 MPa para aquelas com paredes maciças. Na Tabela 3.1 são apresentadas as especificações geométricas, de acordo com a sua resistência nominal, para todos os blocos e meio-blocos utilizados neste trabalho.

Tabela 3.1 - Especificação das unidades cerâmicas

\begin{tabular}{cccccc}
\hline \hline \multirow{2}{*}{ Tipo } & \multirow{2}{*}{ Unidade } & \multirow{2}{*}{$\begin{array}{c}\text { Resistência } \\
\text { nominal }\end{array}$} & \multicolumn{3}{c}{ Dimensões nominais (mm) } \\
\cline { 4 - 6 } & & Largura & Altura & Comprimento \\
\hline \hline Paredes & Bloco & $8,0 \mathrm{MPa}$ & 140 & 190 & 290 \\
vazadas & Meio-bloco & $8,0 \mathrm{MPa}$ & 140 & 190 & 140 \\
\hline Paredes & Bloco & $14,0 \mathrm{MPa}$ & 140 & 190 & 290 \\
maciças & Meio-bloco & $14,0 \mathrm{MPa}$ & 140 & 190 & 140 \\
\hline \hline
\end{tabular}

Fonte: Autor (2020).

Posteriormente, foram realizados os ensaios de caracterização geométrica, física e mecânica das unidades de acordo com a ABNT NBR 15270-2:2017, observando os requisitos, tolerância e quantidades amostradas segundo a ABNT NBR 15270-1:2017. A Tabela 3.2 descreve as principais propriedades avaliadas, tal como a quantidade de unidades ensaiadas para cada análise.

Tabela 3.2 - Propriedades avaliadas nas unidades cerâmicas

\begin{tabular}{cccc}
\hline \multirow{2}{*}{ Caracterização } & Propriedades avaliadas & \multicolumn{2}{c}{ Quantidade de amostras } \\
\cline { 3 - 4 } & Dimensões efetivas & Blocos & Meio-blocos \\
\hline \multirow{3}{*}{ Geométrica } & Espessura dos septos e paredes externas & 13 & 13 \\
& Desvio em relação ao esquadro & 13 & 13 \\
& Planeza das faces & 13 & 13 \\
& Área bruta & 13 & 13 \\
Física & Área líquida & 13 & 13 \\
& Massa seca & 6 & 6 \\
\hline \multirow{2}{*}{ Mecânica } & Índice de absorção & 6 & 6 \\
& Resistência à compressão & 13 & 13 \\
& Módulo de elasticidade & 13 & - \\
\hline \hline
\end{tabular}

Fonte: Autor (2020). 


\subsubsection{Propriedades geométricas}

Para determinação das propriedades geométricas foram seguidas as recomendações da ABNT NBR 15270-2:2017. As propriedades foram obtidas com o auxílio de um paquímetro com sensibilidade de $0,01 \mathrm{~mm}$ e curso total de $150 \mathrm{~mm}$, uma régua com resolução de $1 \mathrm{~mm}$, um esquadro metálico de $90^{\circ}$ e uma balança digital com resolução de $0,1 \mathrm{~g}$.

Os blocos e meio-blocos foram dispostos sobre uma superfície plana e indeformável, e as medidas obtidas são resultados da média entre as medições realizadas em duas faces opostas da largura, comprimento e da altura, conforme observado na Figura 3.2.

Figura 3.2 - Determinação das dimensões efetivas das unidades de paredes vazadas e maciças

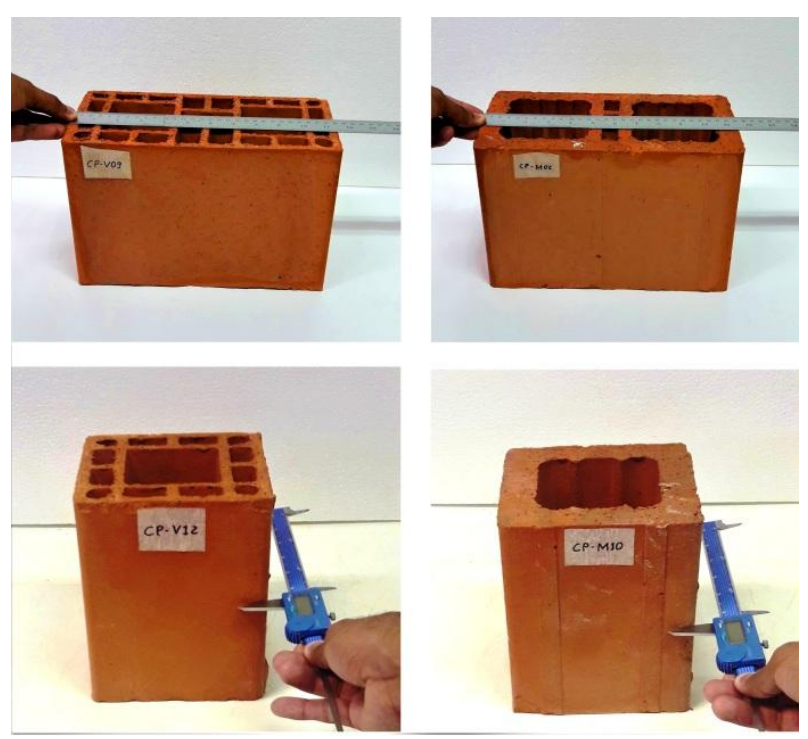

Fonte: Autor (2020).

A Tabela 3.3 apresenta os valores médios para as dimensões efetivas dos blocos e meio-blocos cerâmicos.

Tabela 3.3 - Dimensões médias efetivas das unidades cerâmicas (mm)

\begin{tabular}{cccc|ccc}
\hline \hline & \multicolumn{3}{c}{ Bloco } & \multicolumn{3}{c}{ Meio-bloco } \\
\cline { 2 - 6 } & Largura & Altura & Comprimento & Largura & Altura & Comprimento \\
\hline \hline \multicolumn{6}{c}{ Unidades cerâmicas com paredes vazadas } \\
\hline \hline Média & 140,46 & 188,77 & 289,65 & 139,23 & 189,92 & 140,37 \\
DP & 0,51 & 1,30 & 1,13 & 0,82 & 0,45 & 0,64 \\
CV (\%) & 0,36 & 0,69 & 0,39 & 0,59 & 0,24 & 0,45 \\
\hline \hline \multicolumn{7}{c}{ Unidades cerâmicas com paredes maciças } \\
\hline Média & 141,13 & 189,02 & 291,94 & 138,81 & 188,27 & 140,20 \\
DP & 0,39 & 0,73 & 0,74 & 0,39 & 0,51 & 0,52 \\
CV (\%) & 0,27 & 0,39 & 0,25 & 0,28 & 0,27 & 0,37 \\
\hline \hline
\end{tabular}

Fonte: Autor (2020). 
A ABNT NBR 15270-1:2017 estabelece a tolerância de \pm 3,0 mm para valores individuais. Observa-se através do Apêndice A que todas as unidades atenderam às recomendações, com exceção do valor da altura efetiva de uma unidade de bloco cerâmico de paredes vazadas, com valor inferior a $187 \mathrm{~mm}$. No entanto, esta quantidade de unidades não conformes não é suficiente para a rejeição do lote, conforme cita o mesmo código normativo.

A obtenção das dimensões dos septos e paredes externas foi realizada buscando os pontos onde a parede do bloco apresentava a menor espessura, sendo realizadas quatro medidas para as paredes externas dos blocos e quatro medidas para os septos, como pode ser observado na Figura 3.3.

Figura 3.3 - Determinação da espessura dos septos e das paredes externas
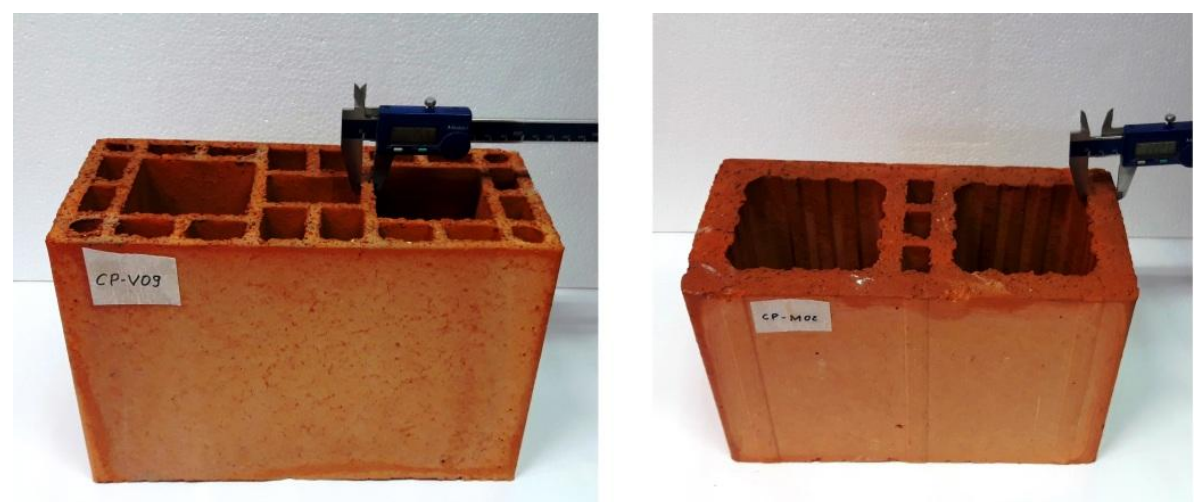

Fonte: Autor (2020).

O desvio em relação ao esquadro foi obtido com auxílio de esquadro metálico de $90^{\circ} \mathrm{e}$ paquímetro. Por conta da disponibilidade de defletômetros no Laboratório de Estruturas, a planeza das faces foi determinada através de procedimento similar mediante utilização de régua metálica e medida de profundidade de um paquímetro com resolução de $0,01 \mathrm{~mm}$, conforme apresentado na Figura 3.4. Os valores médios de cada uma das medidas são apresentados na Tabela 3.4.

Figura 3.4 - Determinação do desvio em relação ao esquadro e planeza das faces
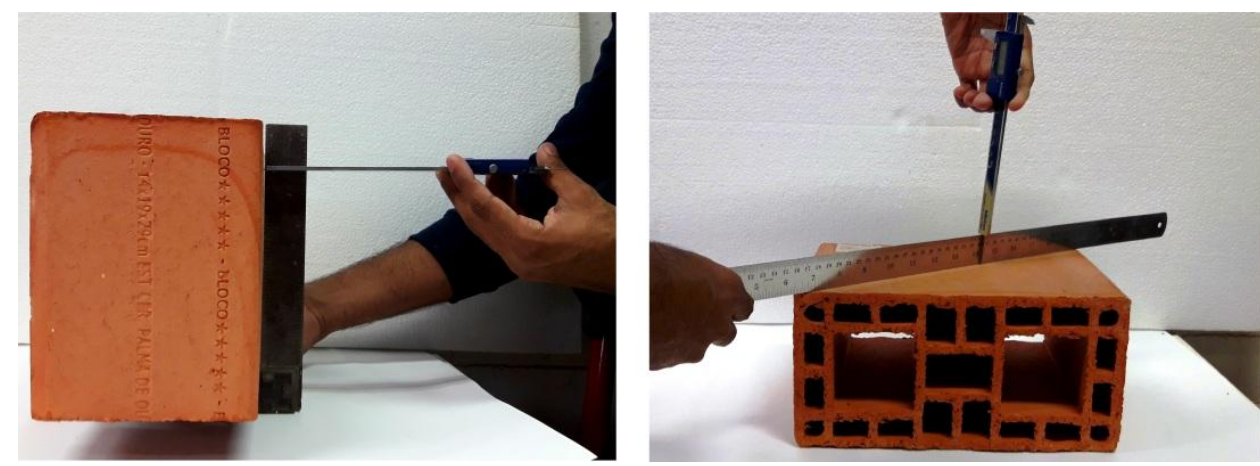

Fonte: Autor (2020). 
Tabela 3.4 - Espessura dos septos e paredes externas, desvio em relação ao esquadro e planeza das faces $(\mathrm{mm})$

\begin{tabular}{ccc|cc}
\hline \hline & $\begin{array}{c}\text { Paredes } \\
\text { externas }\end{array}$ & Septos & $\begin{array}{c}\text { Desvio do } \\
\text { esquadro }\end{array}$ & $\begin{array}{c}\text { Planeza das } \\
\text { faces }\end{array}$ \\
\hline \hline \multicolumn{6}{c}{ Blocos cerâmicos com paredes vazadas } \\
\hline Média & 9,30 & 7,72 & 1,52 & 0,99 \\
DP & 0,49 & 0,37 & 0,35 & 0,42 \\
CV $(\%)$ & 5,32 & 4,71 & 22,84 & 43,08 \\
\hline \hline \multicolumn{6}{c}{ Média } & 22,37 & 11,71 & 1,65 & 1,53 \\
DP & 0,52 & 0,60 & 0,83 & 0,33 \\
CV $(\%)$ & 2,32 & 5,54 & 50,21 & 21,51 \\
\hline \hline
\end{tabular}

Fonte: Autor (2020).

Para a resistência característica nominal utilizada, a ABNT NBR 15270-1 indica que, para blocos com paredes vazadas, a espessura mínima das paredes externas e septos devem ser de 8,0 e 7,0 mm, respectivamente. Para os blocos com paredes maciças, a espessura das paredes externas e septos transversais não devem ser menores que $20 \mathrm{~mm} \mathrm{e} 8,0 \mathrm{~mm}$, respectivamente. $\mathrm{O}$ desvio em relação ao esquadro e planeza das faces deverão ser inferiores a 3,0 mm. Desta maneira, todas as recomendações quanto às medidas acima foram atendidas.

A área bruta foi obtida através do produto entre a largura e comprimento efetivos de cada unidade, sem o desconto das áreas dos furos e reentrâncias. Em seguida, obteve-se a área líquida utilizando o princípio de Arquimedes, ou seja, a partir do volume de água deslocado através da aferição das massas aparente e saturada das unidades, conforme a Equação 3.1.

Onde:

$$
A_{l i q}=\frac{M_{u}-M_{a}}{\gamma \cdot h} \cdot 1000
$$

$A_{l i q}$ é a área líquida da unidade $\left(\mathrm{em} \mathrm{mm}^{2}\right)$;

$M_{u}$ é a massa do bloco saturado (em g);

$M_{a}$ é a massa aparente do bloco, obtida através de pesagem hidrostática (em g);

$\gamma$ é a massa específica da água, admitido como $1 \mathrm{~g} / \mathrm{cm}^{3}$;

$h$ é a altura do bloco (em $\mathrm{mm})$.

A Figura 3.5 apresenta o procedimento para determinação da área líquida, e em seguida, a Tabela 3.5 apresenta os resultados médios de área bruta, líquida e a relação $A_{\text {liq }} / A_{\text {bruta }}$ para os blocos e meio-blocos cerâmicos utilizados. 
Figura 3.5 - Determinação das massas aparente e saturada das unidades cerâmicas
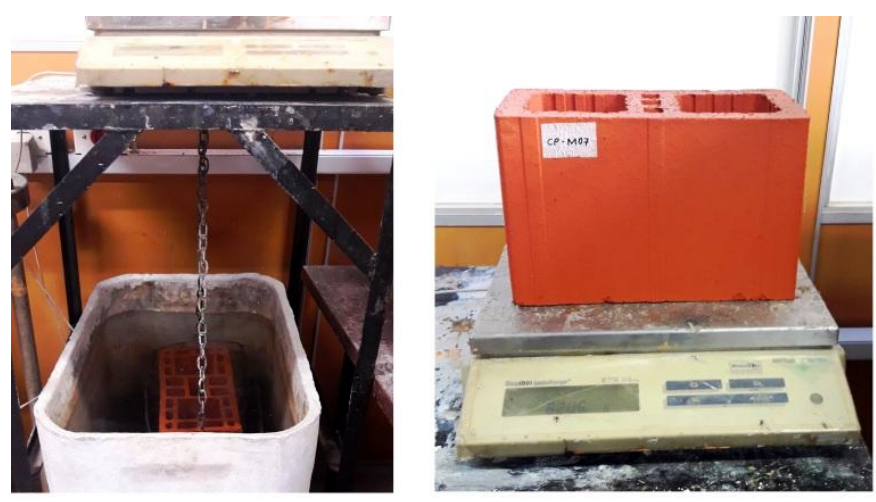

Fonte: Autor (2020).

Tabela 3.5 - Área bruta, área líquida e relação $A_{\text {liq }} / A_{\text {bruta }}$

\begin{tabular}{cccc|ccc}
\hline \hline & \multicolumn{3}{c|}{ Bloco } & \multicolumn{3}{c}{ Meio-bloco } \\
\cline { 2 - 7 } & $\begin{array}{c}\text { Área bruta } \\
\left(\mathrm{mm}^{2}\right)\end{array}$ & $\begin{array}{c}\text { Área } \\
\text { líquida } \\
\left(\mathrm{mm}^{2}\right)\end{array}$ & $\begin{array}{c}A_{\text {liq }} / A_{\text {bruta }}(\%) \\
\text { Unidades cerâmicas com paredes vazadas }\end{array}$ & $\begin{array}{c}\text { Área bruta } \\
\left(\mathrm{mm}^{2}\right)\end{array}$ & $\begin{array}{c}\text { Área } \\
\text { líquida } \\
\left(\mathrm{mm}^{2}\right)\end{array}$ & $\begin{array}{c}A_{\text {liq }} / A_{\text {bruta }} \\
(\%)\end{array}$ \\
\hline \hline Média & 40686,13 & 14949,64 & 36,74 & 19543,50 & 8079,45 & 41,34 \\
DP & 279,05 & 168,65 & 0,28 & 167,90 & 121,10 & 0,37 \\
CV (\%) & 0,69 & 1,13 & 0,76 & 0,86 & 1,50 & 0,89 \\
\hline \hline Média & 41290,26 & 20188,15 & 48,89 & 19460,37 & 11314,51 & 58,14 \\
DP & 143,86 & 100,27 & 0,18 & 104,34 & 45,37 & 0,21 \\
CV (\%) & 0,35 & 0,50 & 0,37 & 0,54 & 0,40 & 0,36 \\
\hline \hline
\end{tabular}

Fonte: Autor (2020).

\subsubsection{Propriedades físicas}

Avaliaram-se as propriedades físicas das unidades cerâmicas através da massa seca e índice de absorção de água. Ambas as características físicas foram obtidas conforme as recomendações da ABNT NBR 15270-2:2017 utilizando uma balança digital com resolução de 0,01 g e estufa com controle de temperatura ajustável a $105^{\circ} \mathrm{C} \pm 5^{\circ} \mathrm{C}$.

A massa seca foi determinada após os corpos de prova submeterem-se à secagem em estufa por 24 horas, e pesagem posterior imediatamente após a remoção da estufa. Foram realizadas duas pesagens consecutivas com intervalo mínimo de uma hora, até que os resultados não divergiram em mais de $0,25 \%$.

Em seguida, os blocos foram submersos novamente em água à temperatura ambiente de $20{ }^{\circ} \mathrm{C} \pm 5{ }^{\circ} \mathrm{C}$ durante 24 horas e pesados sem excesso de água em suas superfícies para 
obtenção da massa úmida. O índice de absorção de água em cada corpo de prova foi determinado a partir da relação entre a massa úmida e massa seca do mesmo, como descrito pela Equação 3.2.

Onde:

$$
A A=\frac{M_{u}-M_{s}}{M_{S}} \cdot 100
$$

$A A$ é o índice de absorção de água (em \%);

$M_{u}$ é a massa úmida do corpo de prova (em g);

$M_{a}$ é a massa seca do corpo de prova (em $\left.\mathrm{g}\right)$.

A Figura 3.6 apresenta os blocos durante o processo de secagem na estufa para obtenção da massa seca, e submersão em água à temperatura ambiente para aquisição da massa úmida. Em seguida, a Tabela 3.6 destaca os valores médios para as propriedades físicas dos blocos e meio-blocos descritos anteriormente.

Figura 3.6 - Procedimento de secagem e saturação dos blocos cerâmicos
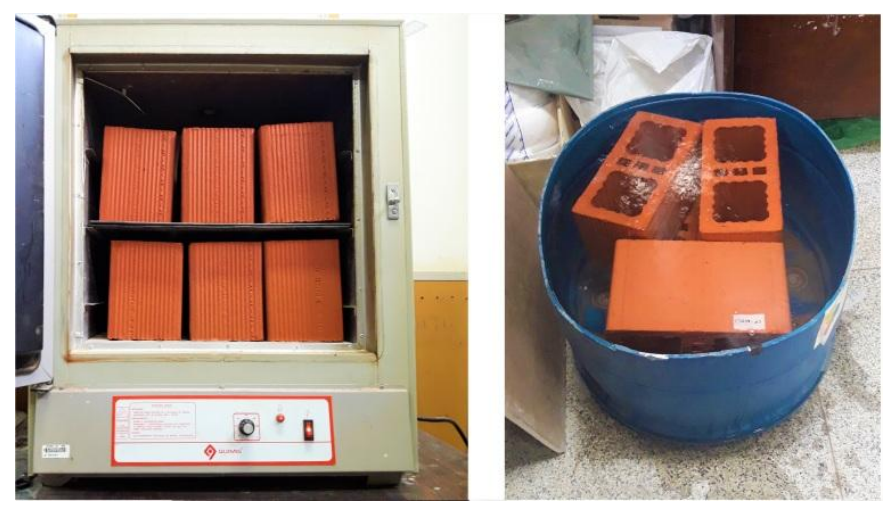

Fonte: Autor (2020).

Tabela 3.6 - Massa seca, massa úmida e índice de absorção das unidades cerâmicas

\begin{tabular}{cccc|ccc}
\hline \hline & \multicolumn{3}{c|}{ Bloco } & \multicolumn{3}{c}{ Meio-bloco } \\
\cline { 2 - 7 } & $\begin{array}{c}\text { Massa seca } \\
(\mathrm{g})\end{array}$ & $\begin{array}{c}\text { Massa } \\
\text { úmida }(\mathrm{g})\end{array}$ & $\begin{array}{c}\text { Índice de } \\
\text { absorção } \\
(\%)\end{array}$ & $\begin{array}{c}\text { Massa } \\
\text { seca }(\mathrm{g})\end{array}$ & $\begin{array}{c}\text { Massa } \\
\text { úmida }(\mathrm{g})\end{array}$ & $\begin{array}{c}\text { Índice de } \\
\text { absorção } \\
(\%)\end{array}$ \\
\hline \hline Média & 5439,33 & 6136,50 & 12,81 & 2903,73 & 3325,02 & 14,51 \\
DP & 52,80 & 83,09 & 0,55 & 21,63 & 24,79 & 0,47 \\
CV (\%) & 0,97 & 1,50 & 4,29 & 0,75 & 0,75 & 3,22 \\
\hline \hline & \multicolumn{7}{c}{ Unidades cerâmicas com paredes vazadas } \\
\hline Média & 7315,67 & 8249,17 & 12,76 & 4145,90 & 4634,03 & 11,77 \\
DP & 39,54 & 69,02 & 0,36 & 34,24 & 37,44 & 0,10 \\
CV (\%) & 0,54 & 0,84 & 2,85 & 0,83 & 0,81 & 0,87 \\
\hline \hline
\end{tabular}

Fonte: Autor (2020). 
A ABNT NBR 15270-1:2017 indica que o índice de absorção de água para unidades cerâmicas estruturais com paredes vazadas ou maciças esteja entre 8,0 \% e 21,0 \%. Portanto, todas as unidades permaneceram entre os limites estabelecidos, com uma variação de apenas $0,39 \%$ entre os dois tipos de blocos.

\subsubsection{Propriedades mecânicas}

\subsubsection{Resistência à compressão e módulo de elasticidade}

As propriedades mecânicas das unidades cerâmicas foram obtidas conforme recomendação da ABNT NBR 15270-2:2017. Durante a realização dos ensaios de resistência à compressão, realizou-se o capeamento das faces superior e inferior dos blocos e meioblocos com placas de forro construído de fibra mineral. As placas de forro com fibra mineral já foram utilizadas em outros trabalhos experimentais no Laboratório de Estruturas como em Mata (2011), Oliveira (2014) e Izquierdo (2015) e, mostraram-se satisfatórias para adequada obtenção das propriedades mecânicas, evitando a concentração de tensões nas superfícies dos blocos em decorrência da conformação irregular ou presença de agregados.

Determinou-se a resistência à compressão dos blocos através de ensaio de compressão utilizando uma máquina Instron Satec ${ }^{\circledR}$, modelo $300 \mathrm{HVL}$, com capacidade nominal de $1500 \mathrm{kN}$, e aplicação de controle de deslocamentos a uma velocidade de $0,02 \mathrm{~mm} / \mathrm{s}$. Além disso, para obtenção do módulo de elasticidade dos blocos cerâmicos foram utilizados dois clip-gages de base igual a $100 \mathrm{~mm}$, posicionados de forma antissimétrica nas duas faces longitudinais dos blocos, conforme apresentado na Figura 3.7.

Figura 3.7 - Ensaio de resistência à compressão em bloco cerâmico
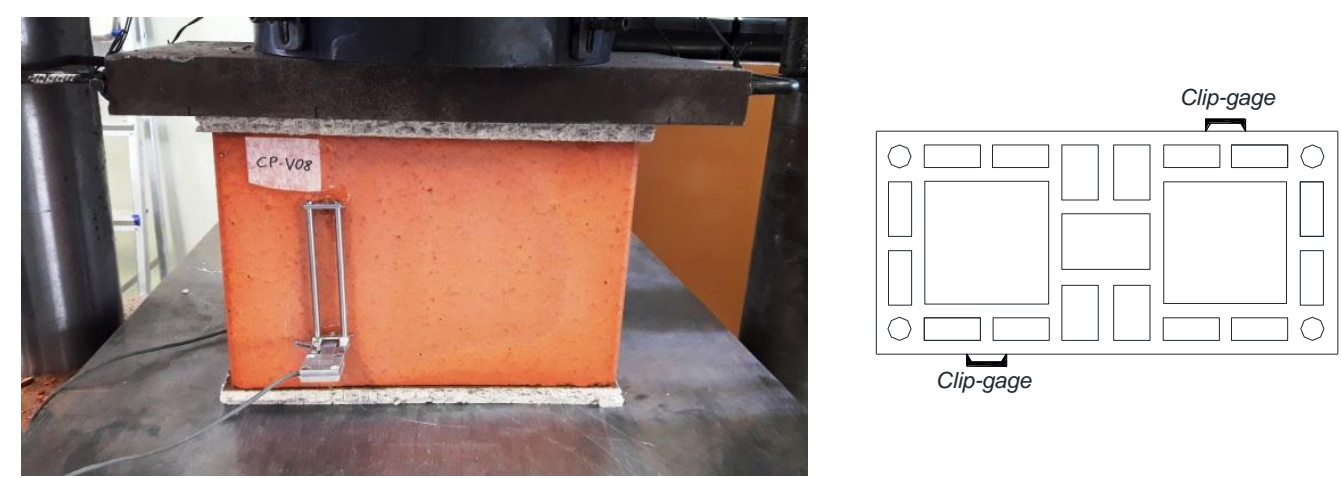

Fonte: Autor (2020).

Dessa maneira, possibilitou-se a aquisição das curvas tensão x deformação específica apresentadas na Figura 3.8, e a determinação do módulo de elasticidade secante, que foi obtido conforme recomendação do ACI 530-05:2005, cujo trecho de análise será aquele 
situado entre $5 \%$ e $33 \%$ da tensão de ruptura. Acrescenta-se ainda que, todos os diagramas tensão x deformação apresentados neste trabalho com valores positivos, referem-se a tensões compressivas e deformações de encurtamento, com exceção daqueles expostos em 3.2.3.2.

Figura 3.8 - Diagrama tensão x deformação dos blocos com paredes (a) vazadas e (b) maciças

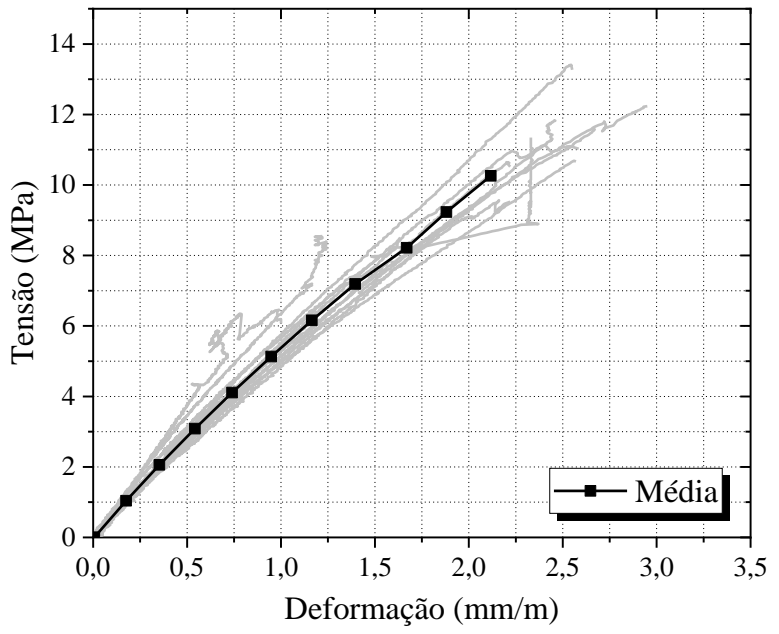

(a)

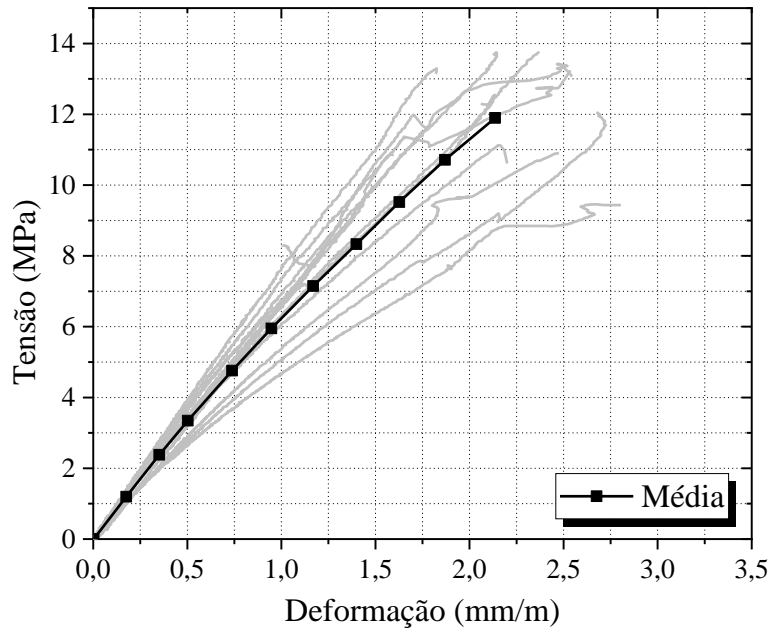

(b)

Fonte: Autor (2020).

A resistência característica à compressão das unidades foi calculada conforme o item 5.7 da ABNT NBR 15270-1:2017, a partir da resistência à compressão estimada e ponderação devido ao número de corpos de prova ensaiados. Os valores médios e característicos da resistência à compressão dos blocos, além do módulo de elasticidade das unidades são apresentados na Tabela 3.7.

Tabela 3.7 - Resistência à compressão e módulo de elasticidade dos blocos cerâmicos

\begin{tabular}{cccccc}
\hline \hline & $\begin{array}{c}\text { Força } \\
(\mathbf{k N})\end{array}$ & $\begin{array}{c}\text { Resistência na } \\
\boldsymbol{A}_{\text {bruta }}(\mathbf{M P a})\end{array}$ & $\begin{array}{c}\text { Resistência na } \\
\boldsymbol{A}_{\text {liq }}(\mathbf{M P a})\end{array}$ & $\begin{array}{c}\text { E na } \boldsymbol{A}_{\text {bruta }} \\
(\mathbf{G P a})\end{array}$ & $\begin{array}{c}\text { E na } \boldsymbol{A}_{\text {liq }} \\
(\mathbf{G P a})\end{array}$ \\
\hline \hline Média & 417,35 & 10,26 & 27,92 & 5,76 & 15,68 \\
DP & 81,54 & 2,03 & 5,52 & 0,80 & 2,17 \\
$\mathbf{C V}(\boldsymbol{\%})$ & 19,54 & 19,76 & 19,76 & 13,90 & 13,90 \\
$\mathbf{f}_{\text {bk }}$ & - & 6,39 & 17,39 & - & - \\
\hline \hline & \multicolumn{6}{c}{ Blocos cerâmicos com paredes vazadas } \\
\hline Média & 491,12 & 11,90 & 24,34 & 6,62 & 13,54 \\
DP & 69,62 & 1,70 & 3,48 & 0,85 & 1,74 \\
CV $(\%)$ & 14,18 & 14,33 & 14,33 & 12,79 & 12,79 \\
$\mathbf{f}_{\text {bk }}$ & - & 8,28 & 16,93 & - & - \\
\hline \hline
\end{tabular}

Fonte: Autor (2020).

De maneira similar, os meio-blocos cerâmicos com paredes vazadas e maciças submeteram-se a ensaios de compressão realizados no mesmo equipamento e sob as mesmas 
condições de capeamento e carregamento, de acordo com a Figura 3.9. O módulo de elasticidade e os diagramas tensão x deformação são apresentados na Figura 3.10, e foram obtidos instalando-se dois clip-gages com $100 \mathrm{~mm}$ de base em ambas as faces longitudinais dos meio-blocos.

Figura 3.9 - Ensaio de resistência à compressão em meio-bloco cerâmico
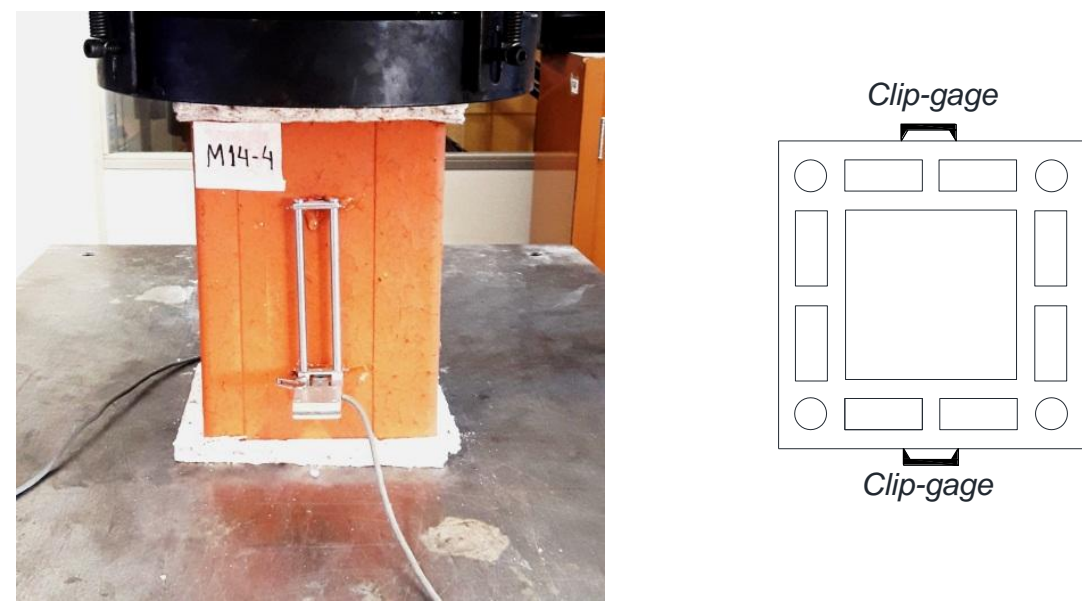

Fonte: Autor (2020).

Figura 3.10 - Diagramas tensão x deformação dos meio-blocos com paredes (a) vazadas e (b) maciças

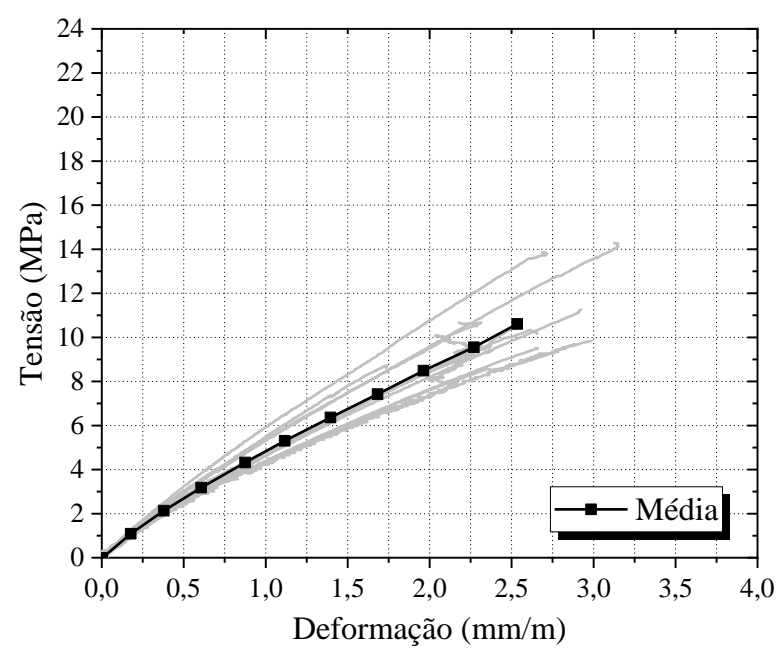

(a)

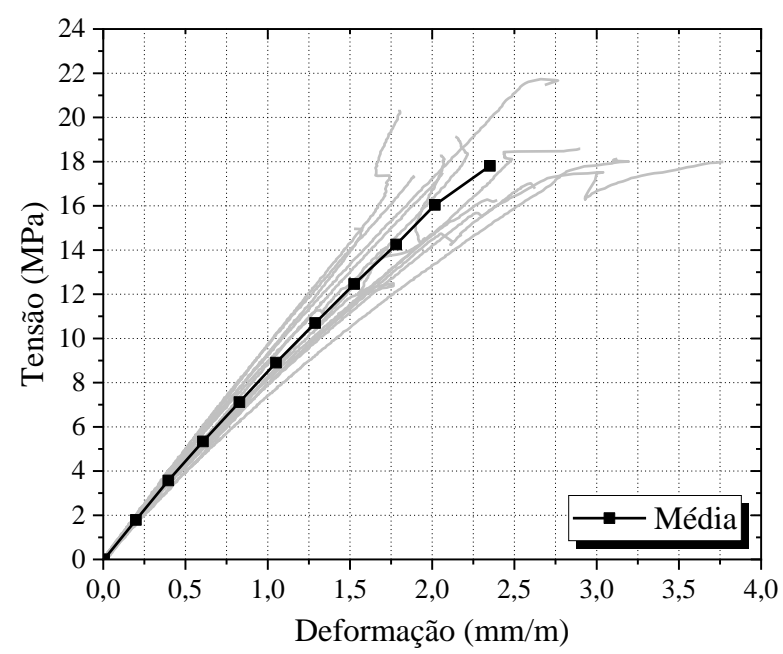

(b)

Fonte: Autor (2020).

Embora a ABNT NBR 15270-2:2017 prescreva que os ensaios mecânicos devam ser realizados com os corpos de prova na condição saturada, após imersão em água, todos os testes mecânicos realizados neste trabalho ocorreram com as unidades secas e submetidas à temperatura ambiente, devido à fixação dos clip-gages utilizando dispositivo à quente. Destaca-se ainda que, todas as amostras foram avaliadas segundo o teste estatístico de Grubbs para verificar a existência de valores espúrios. As especificidades do referido teste são 
apresentadas com maiores detalhes no Apêndice A.

A Tabela 3.8 apresenta os valores médios e característicos da resistência à compressão e módulo de elasticidade dos meio-blocos cerâmicos.

Tabela 3.8 - Resistência à compressão e módulo de elasticidade dos meio-blocos

\begin{tabular}{cccccc}
\hline \hline & $\begin{array}{c}\text { Força } \\
(\mathbf{k N})\end{array}$ & $\begin{array}{c}\text { Resistência na } \\
\boldsymbol{A}_{\text {bruta }}(\mathbf{M P a})\end{array}$ & $\begin{array}{c}\text { Resistência na } \\
\boldsymbol{A}_{\text {liq }}(\mathbf{M P a})\end{array}$ & $\begin{array}{c}\text { E na } \boldsymbol{A}_{\text {bruta }} \\
(\mathbf{G P a})\end{array}$ & $\begin{array}{c}\text { E na } \boldsymbol{A}_{\text {liq }} \\
(\mathbf{G P a})\end{array}$ \\
\hline \hline Média & 207,17 & 10,60 & 25,64 & 5,07 & 12,26 \\
$\mathbf{D P}$ & 32,18 & 1,68 & 4,06 & 0,51 & 1,23 \\
$\mathbf{C V}(\boldsymbol{\%})$ & 15,53 & 15,85 & 15,85 & 10,07 & 10,07 \\
$\mathbf{f}_{\text {bk }}$ & - & 8,88 & 21,48 & - & - \\
\hline \hline & \multicolumn{5}{c}{ Meio-blocos cerâmicos com paredes vazadas } \\
Média & 346,50 & 17,80 & 30,62 & 15,08 \\
DP & 39,68 & 2,03 & 3,49 & 8,77 & 1,32 \\
CV $(\boldsymbol{\%})$ & 11,45 & 11,42 & 11,42 & 0,77 & 8,73 \\
$\mathbf{f}_{\text {bk }}$ & - & 14,40 & 24,77 & - & - \\
\hline \hline
\end{tabular}

Fonte: Autor (2020).

De modo geral, a ruptura das unidades cerâmicas ocorreu de maneira brusca e explosiva devido ao comportamento frágil do material. Assim, a mesma foi caracterizada pelo estilhaçamento do material e formação de fissuras características devido ao elevado confinamento provocado pela prensa hidráulica, conforme pode ser visto na Figura 3.11.

Figura 3.11 - Modo de ruptura das unidades cerâmicas
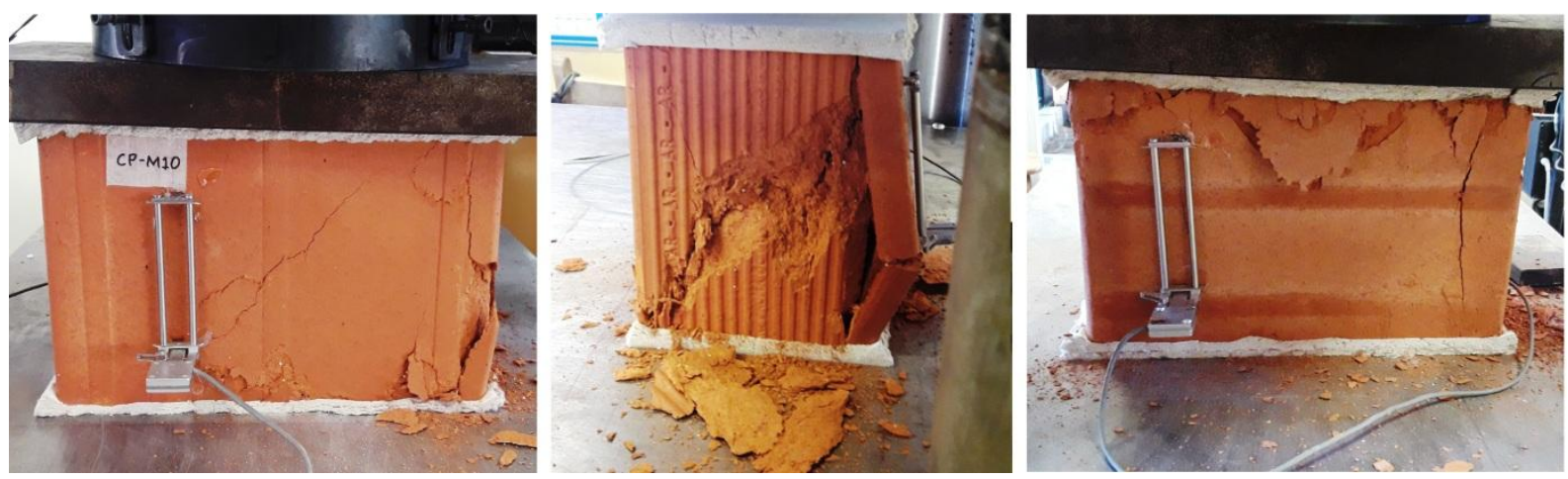

Fonte: Autor (2020).

\subsubsection{Resistência à tração indireta}

O ensaio de resistência à tração indireta dos blocos cerâmicos foi realizada de acordo com as prescrições normativas da ASTM C1006-7:2013, que padroniza o ensaio de tração indireta (splitting test) em unidades de alvenaria através do surgimento de um estado de 
tensões de tração distribuídas ao longo da altura do bloco, quando este é comprimido por meio de hastes metálicas ao longo do mesmo eixo.

Observou-se em trabalhos anteriores que a utilização de hastes cilíndricas posicionadas no centro do bloco ocasionava o esmagamento do mesmo, ao invés de cisalhálo. Dessa forma, durante o ensaio foram utilizadas hastes metálicas com seção retangular de 2,0 x 1,5 cm, posicionadas no ponto médio de uma das áreas vazadas laterais do bloco, com a incidência apenas de paredes e septos ortogonais a aplicação do carregamento. Este mesmo procedimento já foi realizado em pesquisas precedentes como Oliveira (2014) e Izquierdo (2015).

Para realização dos ensaios à tração indireta nos blocos cerâmicos de alvenaria, utilizou-se uma máquina Instron Satec ${ }^{\circledR}$, modelo 300 HVL, com capacidade nominal de 1500 $\mathrm{kN}$, e aplicação de controle de deslocamentos com velocidade de $0,002 \mathrm{~mm} / \mathrm{s}$. O procedimento de ensaio pode ser visto na Figura 3.12.

Figura 3.12 - Ensaio de tração indireta em blocos com paredes (a) vazadas e (b) maciças
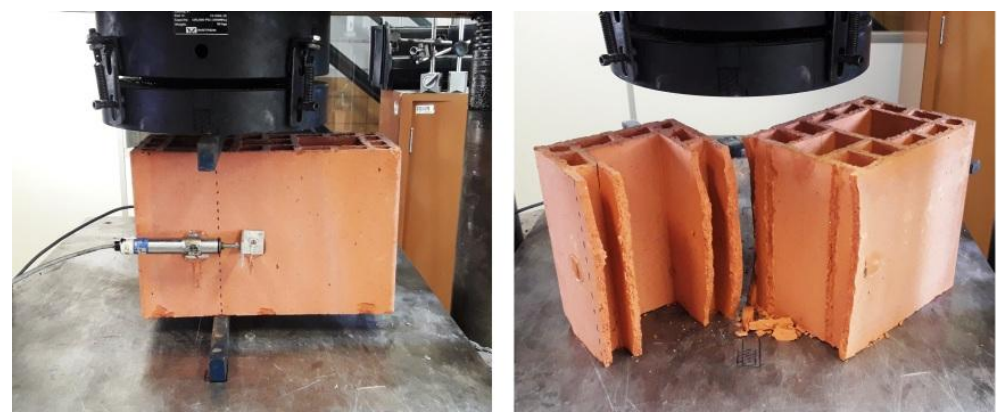

(a)

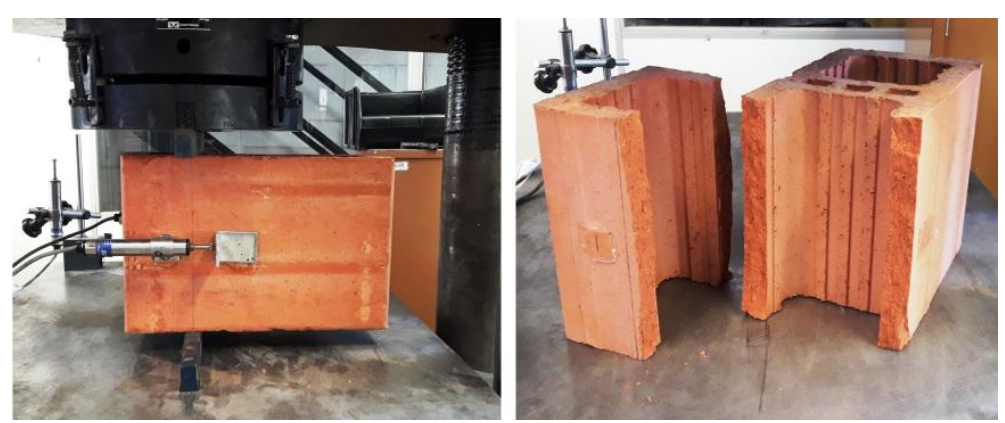

(b)

Fonte: Autor (2020).

A utilização de dois transdutores de deslocamento com curso de $50 \mathrm{~mm}$ posicionados perpendicularmente a linha de ação do carregamento e adjacente a região de formação da fissura, possibilitou a obtenção dos diagramas tensão x deformação apresentados na Figura 3.13, que evidenciaram a grande variabilidade dos resultados do ensaio e a ruptura frágil do material, que dificultou a avaliação da fratura do mesmo através da sua abertura de fissura. 
Figura 3.13 - Diagramas tensão x deformação dos blocos com paredes (a) vazadas e (b) maciças submetidos à tração indireta

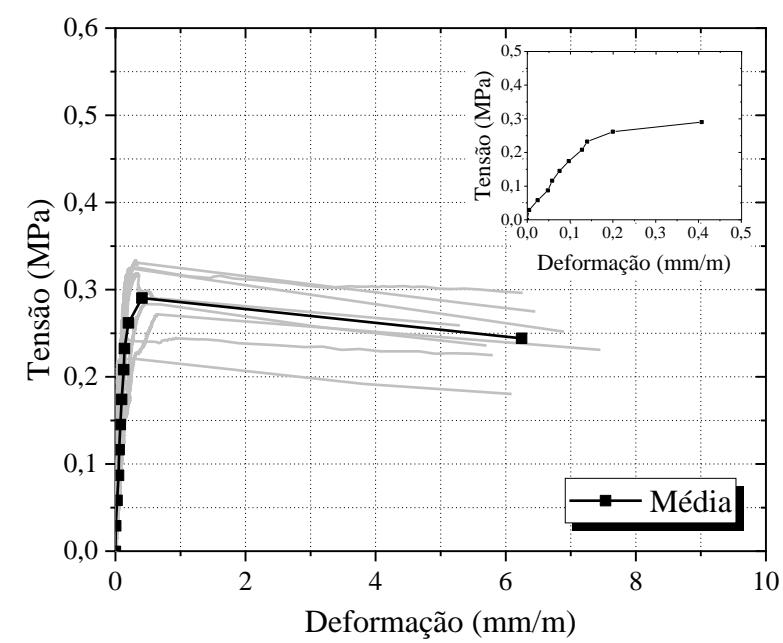

(a)

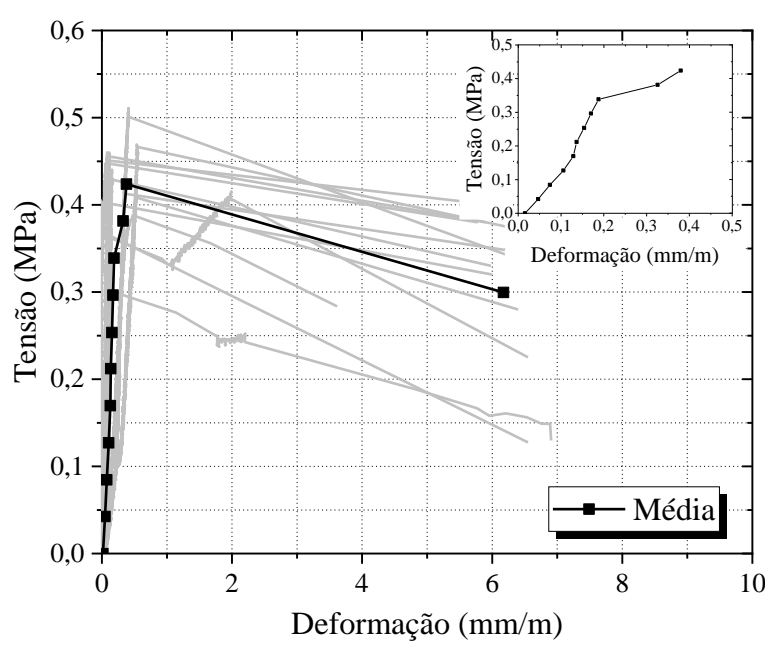

(b)

Fonte: Autor (2020).

A resistência à tração indireta do bloco é dada a partir da Equação 3.3.

$$
f_{t}=\frac{2 P}{\pi \cdot L \cdot H}
$$

Onde:

$f_{t}$ é a resistência à tração indireta do bloco (em MPa);

$P$ é a máxima carga aplicada $(\mathrm{em} \mathrm{N})$;

$L$ é a dimensão da amostra sob a linha de carregamento descontada os vazios (em mm);

$H$ é a distância entre as duas hastes aplicadoras de carga (em mm).

A Tabela 3.9 apresenta a resistência média à tração indireta para os dois tipos de blocos cerâmicos, considerando a largura total do bloco e a soma das larguras dos septos transversais, para o cálculo da resistência na área líquida, respectivamente.

Tabela 3.9 - Resistência à tração indireta dos blocos cerâmicos

\begin{tabular}{cccc}
\hline \hline & Força $(\mathbf{k N})$ & $\begin{array}{c}\mathbf{f}_{\text {tb,ind }} \text { na } \boldsymbol{A}_{\text {bruta }} \\
(\mathbf{M P a})\end{array}$ & $\begin{array}{c}\mathbf{f}_{\text {tb,ind }} \mathbf{\text { na }} \\
(\mathbf{M P a})\end{array}$ \\
\hline \hline Média & Blocos cerâmicos com paredes vazadas \\
DP & 22,37 & 0,269 & 1,108 \\
CV $(\boldsymbol{\%})$ & 4,43 & 0,053 & 0,219 \\
\hline \hline \multicolumn{4}{c}{ Blocos cerâmicos com paredes maciças } \\
\hline Média & 35,59 & 0,424 & 19,79 \\
DP & 4,42 & 0,053 & 1,339 \\
CV (\%) & 12,43 & 12,43 & 0,166 \\
\hline \hline
\end{tabular}

Fonte: Autor (2020). 


\subsection{ARGAMASSAS}

\subsubsection{Aglomerantes}

Para confecção das argamassas de assentamento e revestimento aplicadas neste trabalho, utilizaram-se três aglomerantes, sendo estes o cimento, a cal e o gesso. Em particular, empregou-se cimento Portland composto CP II-E classe 32 da Holcim Cimentos, cal hidratada CH III da Itaú e Gesso em pó para revestimento da SM Gesso.

A composição química dos materiais utilizados para produção das argamassas foi determinada na Central de Análises Químicas Instrumentais do Instituto de Química de São Carlos (CAQI - IQSC) através do Espectrômetro por fluorescência de Raios-X, e seguem apresentadas na Tabela 3.10 .

Tabela 3.10 - Composição química dos aglomerantes

\begin{tabular}{cccc}
\hline \hline Composição (\%) & Cimento CP II-E & Cal CH III & Gesso em pó \\
\hline \hline $\mathrm{CaO}$ & 61,996 & 61,268 & 42,769 \\
$\mathrm{SiO}_{2}$ & 24,882 & 2,243 & - \\
$\mathrm{Al}_{2} \mathrm{O}_{3}$ & 5,32 & - & - \\
$\mathrm{Fe}_{2} \mathrm{O}_{3}$ & 2,476 & 0,312 & - \\
$\mathrm{SO}_{3}$ & 2,474 & - & 57,084 \\
$\mathrm{In}_{2} \mathrm{O}_{3}$ & 1,161 & - & - \\
$\mathrm{MgO}$ & - & 36,177 & - \\
$\mathrm{TiO}_{2}$ & 0,491 & - & - \\
$\mathrm{MnO}$ & 0,403 & - & - \\
$\mathrm{SrO}$ & 0,401 & - & 0,147 \\
$\mathrm{~K}_{2} \mathrm{O}$ & 0,394 & - & - \\
\hline \hline
\end{tabular}

Fonte: Autor (2020).

Para avaliação do consumo dos materiais e melhor controle durante a fabricação das argamassas a partir dos traços em massa, realizaram-se ensaios para obtenção das massas específica e unitária para ambos os materiais. A massa específica foi obtida seguindo os critérios da ABNT NBR 16605:2017 (Cimento Portland e outros materiais em pó Determinação da massa específica) através da disposição de uma massa conhecida do material em um frasco volumétrico de Le Chantelier preenchido com querosene. A massa unitária foi determinada de acordo com as prescrições da ABNT NBR NM 45:2006 (Agregados Determinação da massa unitária e do volume de vazios) a partir da relação entre a massa não compactada do material e o volume conhecido de um recipiente metálico preenchido. A Tabela 3.11 apresenta os resultados destas propriedades. 
Tabela 3.11 - Propriedades físicas dos aglomerantes

\begin{tabular}{cccc}
\hline \hline Propriedade & Cimento CP II-E & Cal CH III & Gesso em pó \\
\hline \hline Massa específica $\left(\mathrm{kg} / \mathrm{m}^{3}\right)$ & 2960,0 & 2450,0 & 2600,0 \\
Massa unitária $\left(\mathrm{kg} / \mathrm{m}^{3}\right)$ & 1155,0 & 765,0 & 610,0 \\
\hline \hline
\end{tabular}

Fonte: Autor (2020).

\subsubsection{Agregados}

Na composição das argamassas foram utilizados agregados miúdos que se resumiram a areias naturais com duas granulometrias diferentes. $\mathrm{O}$ aspecto superficial e morfologia dos agregados podem ser observados através da Figura 3.14 obtida a partir de Microscopia Eletrônica por Varredura (MEV). Acrescenta-se que todas as fotomicrografias utilizadas neste trabalho foram obtidas na Central de Análises Químicas Instrumentais do Instituto de Química de São Carlos (CAQI - IQSC) em um microscópio eletrônico modelo ZEISS LEO 440, com detector OXFORD (modelo 7060) operando com feixe de elétrons de $15 \mathrm{kV}$, sendo todas as amostras previamente recobertas com $6 \mathrm{~nm}$ de ouro em um metalizador e mantidas e um dessecador até o instante da análise.

Figura 3.14 - Aspecto superficial das areias (a) fina e (b) grossa

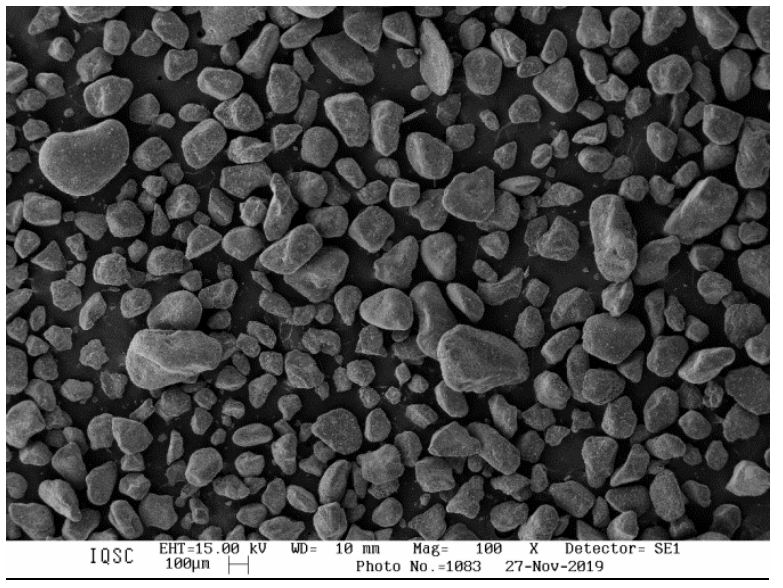

(a)

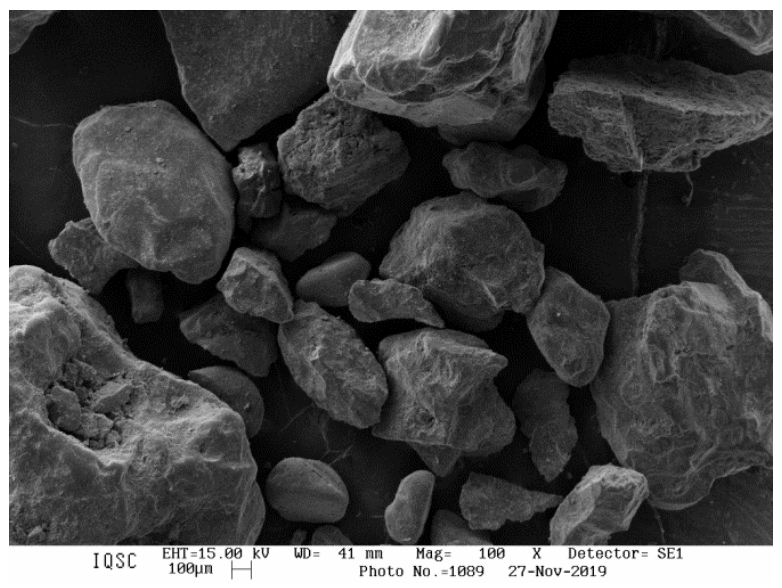

(b)

Fonte: Autor (2020).

De modo análogo ao realizado com os aglomerantes, as propriedades físicas dos agregados foram adquiridas por meio de ensaios das massas específica e unitária. Respectivamente, ambas foram obtidas de acordo com as recomendações da ABNT NBR NM 52:2009 (Agregado miúdo - Determinação da massa específica e massa específica aparente) e ABNT NBR NM 45:2006. Além disso, a ABNT NBR NM 248:2003 (Agregados Determinação da composição granulométrica) possibilitou a avaliação da distribuição 
granulométrica através das curvas apresentadas na Figura 3.15, e pela determinação da dimensão máxima do agregado, sendo esta a correspondente à abertura da malha em que a porcentagem retida acumulada é imediatamente inferior a 5\%, e o módulo de finura, caracterizado pela soma das porcentagens retidas acumuladas nas peneiras da série normal dividida por 100, conforme apresentado na Tabela 3.12 .

Figura 3.15 - Distribuição granulométrica das areias

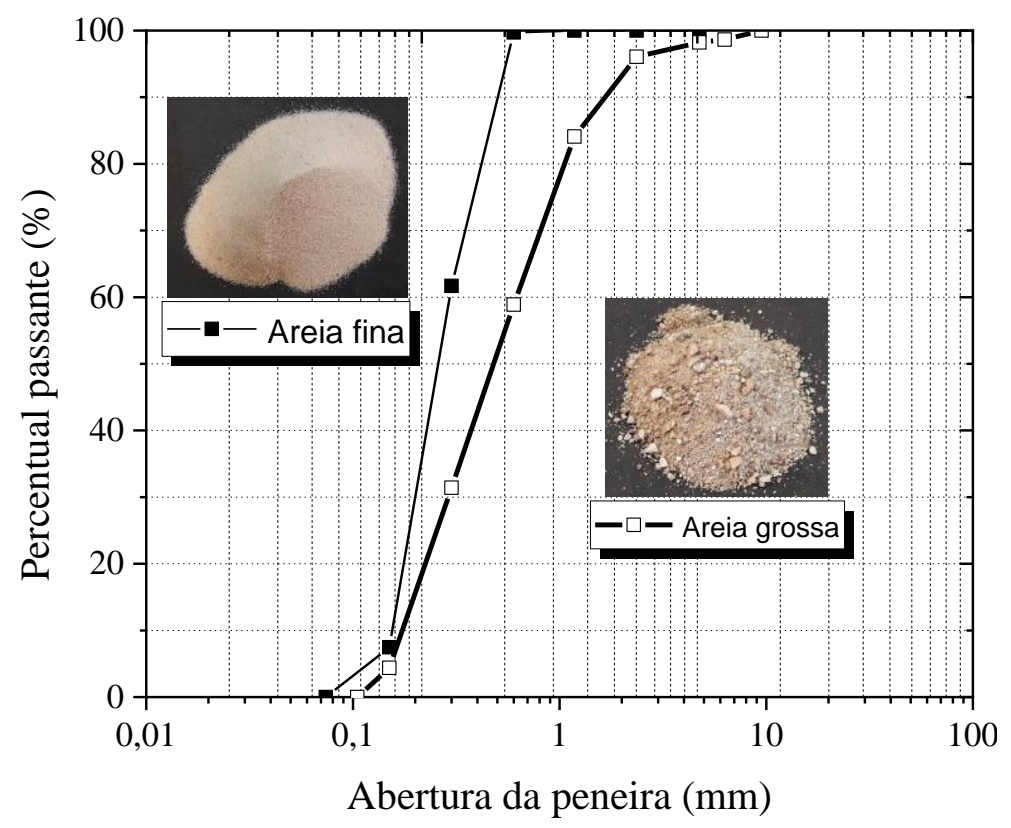

Fonte: Autor (2020).

Tabela 3.12 - Propriedades físicas dos agregados

\begin{tabular}{ccc}
\hline \hline Propriedade & Areia fina & Areia grossa \\
\hline \hline Massa específica $\left(\mathrm{kg} / \mathrm{m}^{3}\right)$ & 2580,0 & 2570,0 \\
Massa unitária $\left(\mathrm{kg} / \mathrm{m}^{3}\right)$ & 1560,0 & 1500,0 \\
Dimensão máxima característica $(\mathrm{mm})$ & 0,60 & 2,36 \\
Módulo de finura & 1,30 & 2,30 \\
\hline \hline
\end{tabular}

Fonte: Autor (2020).

\subsubsection{Argamassa de assentamento}

A argamassa utilizada no assentamento dos prismas e pequenas paredes de alvenaria estrutural foi definida seguindo as recomendações da BS 5628:2005, devido à ausência de uma normatização nacional que regularize a composição das argamassas de assentamento para elementos de alvenaria estrutural. Dessa forma, empregou-se uma argamassa de traço 1:0,5:4,5 medido em volume para os materiais cimento, cal e areia, respectivamente. 
O material foi produzido a partir da utilização de cimento Portland, cal hidratada e areia com granulometria fina. O preparo da argamassa foi realizado com o auxílio de um misturador mecânico de eixo vertical, de acordo com o recomendado pela ABNT NBR 15812-2:2010. A mistura da argamassa foi realizada conforme prescrito pela ABNT NBR 16541:2016 (Argamassa para assentamento e revestimento de paredes e tetos - Preparo da mistura e realização dos ensaios) que sugere a adoção de argamassas cuja quantidade de água seja aquela necessária para obtenção de índice de consistência igual a $260 \pm 5,0 \mathrm{~mm}$.

A argamassa foi caracterizada em seu estado fresco para verificação do índice de consistência seguindo as recomendações da ABNT NBR 13576:2016 (Argamassa para assentamento e revestimento de paredes e tetos - Determinação do índice de consistência). Assim, para realização do ensaio e obtenção da consistência adequada para a mistura, utilizou-se uma mesa para ensaio de consistência, um molde tronco cônico, um soquete e uma régua metálica com resolução de 1,0 mm, conforme ilustrado na Figura 3.16.

Figura 3.16 - Procedimento para obtenção do índice de consistência da argamassa

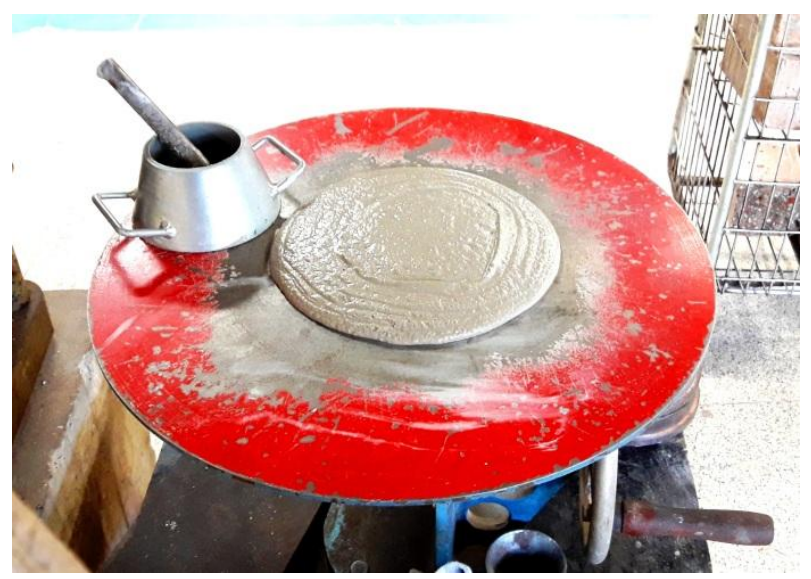

Fonte: Autor (2020).

Para obtenção da consistência recomendada foi necessária a utilização de uma relação água/cimento igual a 1,50, resultando em um índice médio de 261,6 mm obtido a partir da média de três registros realizados em diferentes pontos da mistura. A partir disso, a composição da argamassa foi fixada para utilização em todas as outras etapas deste trabalho e confecção dos elementos de alvenaria estrutural. A Tabela 3.13 indica as principais características da argamassa utilizada.

Tabela 3.13 - Propriedades físicas da argamassa de assentamento

\begin{tabular}{cccc}
\hline \hline & $\begin{array}{c}\text { Traço em volume } \\
\text { (cimento:cal:areia) }\end{array}$ & $\begin{array}{c}\text { Índice de } \\
\text { consistência }(\mathbf{m m})\end{array}$ & $\begin{array}{c}\text { Relação } \\
\text { água/cimento }\end{array}$ \\
\hline Argamassa & $1: 0,5: 4,5$ & 261,6 & 1,50 \\
\hline \hline
\end{tabular}

Fonte: Autor (2020). 
Para caracterização das argamassas no estado endurecido foram realizados ensaios de resistência à compressão e módulo de elasticidade. Embora a ABNT NBR 13279:2005 (Argamassa para assentamento e revestimento de paredes e tetos - Determinação da resistência à tração da flexão e à compressão) recomende a utilização de moldes prismáticos de 4,0 x 4,0 x 16,0 cm para confecção dos corpos de prova de argamassa, devido à baixa disponibilidade desses moldes no Laboratório de Estruturas e elevado número de corpos de prova a serem confeccionados, utilizou-se moldes cilíndricos com $50 \mathrm{~mm}$ de diâmetro e 100 mm de altura.

O processo de moldagem dos corpos de prova foi realizado conforme a ABNT NBR 7215:2019 (Cimento Portland - Determinação da resistência à compressão de corpos de prova cilíndricos). Os moldes foram previamente untados na superfície interna com desmoldante, e posteriormente preenchidos em quatro camadas aproximadamente iguais, cada uma recebendo 30 golpes uniformes e distribuídos com o soquete manual.

Foram confeccionados 10 corpos de prova que, após a moldagem permaneceram em câmara úmida até a realização dos ensaios. A resistência à compressão e módulo de elasticidade foram obtidos aos 28 dias após o processo de moldagem dos corpos de prova de argamassa. Acrescenta-se ainda que antes da realização dos ensaios, todos os corpos de prova submeteram-se ao processo de retífica.

Os ensaios de resistência à compressão foram realizados na máquina servo-hidráulica Instron Satec ${ }^{\circledR}$, modelo $300 \mathrm{HVL}$, e capacidade nominal de $1500 \mathrm{kN}$. O carregamento foi aplicado através de controle de deslocamento a uma velocidade de 0,005 mm/s. Para obtenção da curva tensão x deformação, foram acoplados dois clip-gages com $50 \mathrm{~mm}$ de base, posicionados em lados opostos na região média do corpo de prova, conforme a Figura 3.17.

Figura 3.17 - Ensaio de resistência à compressão da argamassa de assentamento

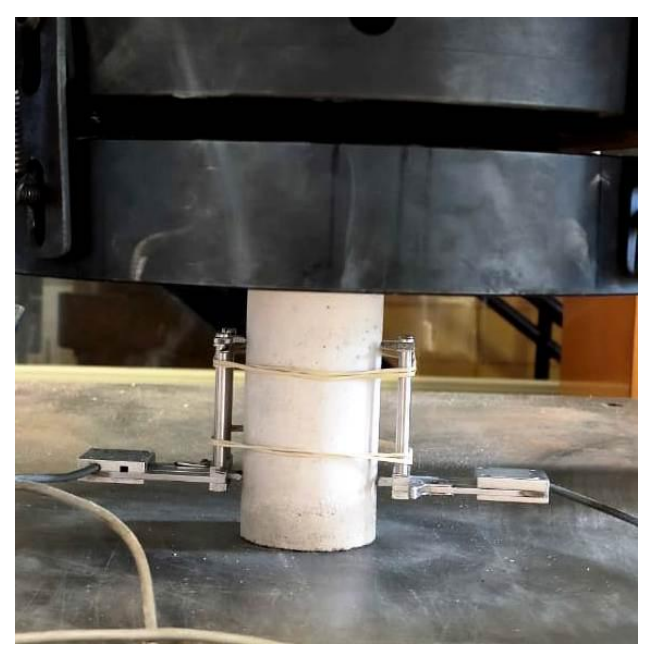

Fonte: Autor (2020). 
Após a obtenção dos diagramas tensão x deformação específica ilustrados na Figura 3.18, o módulo de elasticidade secante das argamassas foi auferido de acordo com as recomendações do ACI 530-05:2005, verificando o comportamento da curva no trecho compreendido entre $5 \%$ e $33 \%$ da tensão de ruptura.

Figura 3.18 - Diagrama tensão x deformação da argamassa de assentamento

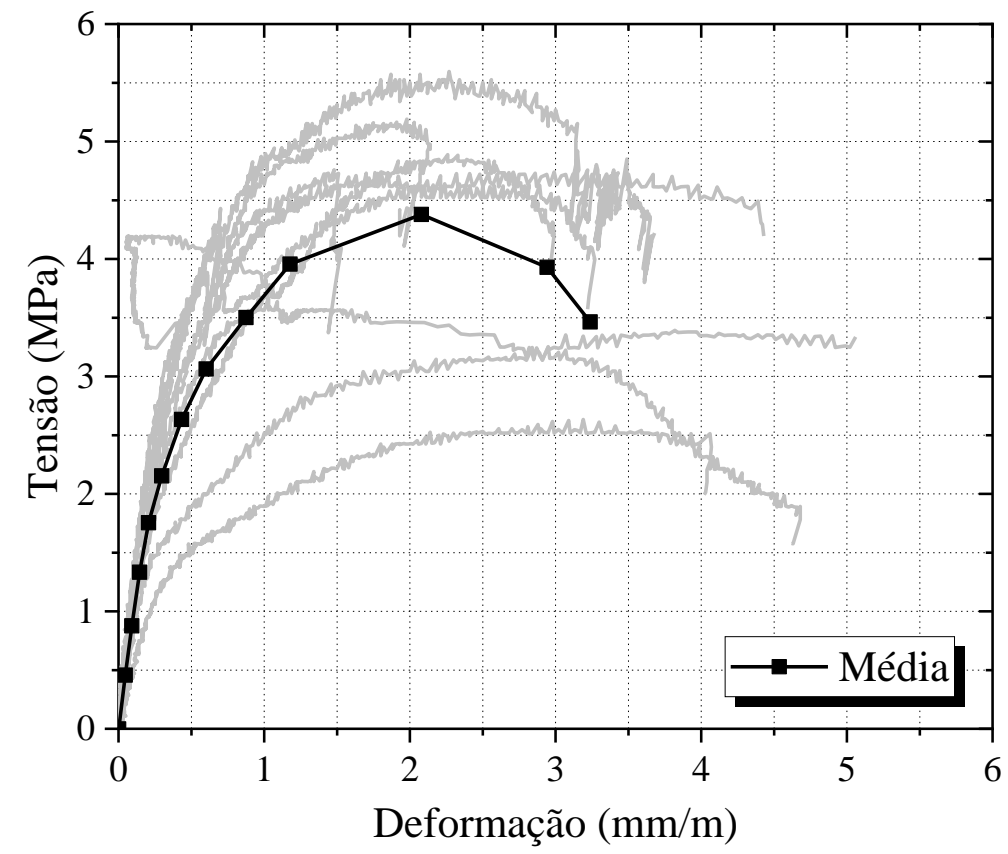

Fonte: Autor (2020).

A Tabela 3.8 indica os valores médios para os resultados obtidos da caracterização mecânica da argamassa de assentamento.

Tabela 3.8 - Propriedades mecânicas da argamassa de assentamento

\begin{tabular}{ccccc}
\hline & Força $(\mathbf{k N})$ & $\boldsymbol{f}_{\mathbf{a}}(\mathbf{M P a})$ & $\boldsymbol{\varepsilon}_{\boldsymbol{p}}(\mathbf{m m} / \mathbf{m})$ & $\boldsymbol{E}_{\mathbf{a}}(\mathbf{G P a})$ \\
\hline \hline Média & 8,60 & 4,38 & 2,08 & 9,70 \\
DP & 1,68 & 0,90 & - & 2,41 \\
CV $(\boldsymbol{\%})$ & 20,64 & 20,64 & - & 24,81 \\
\hline \hline
\end{tabular}

Fonte: Autor (2020).

\subsubsection{Argamassas de revestimento}

Neste trabalho foram utilizados três tipos de revestimento, sendo estes, as argamassas convencionais em cimento Portland, as pastas e argamassas em gesso. A argamassa de revestimento com utilização de cimento Portland foi definida a partir da observação da composição dos principais traços utilizados em atividades práticas e pesquisas científicas no 
Brasil. Assim, empregou-se uma argamassa de traço 1:1,8:3,6, medido em volume para os materiais cimento, cal e areia fina, respectivamente, e relação água/cimento igual a 1,50.

A argamassa de cimento para revestimento foi caracterizada em seu estado fresco de maneira similar ao realizado com a argamassa de assentamento, conforme o item 3.3.3. O material foi preparado segundo as prescrições da ABNT NBR 16541:2016, com consistência verificada conforme a ABNT NBR 13576:2016 através de ensaio em mesa de consistência. A Tabela 3.14 exibe as propriedades físicas da argamassa de cimento para revestimento.

Tabela 3.14 - Propriedades físicas da argamassa de cimento para revestimento

\begin{tabular}{cccc}
\hline \hline & $\begin{array}{c}\text { Traço em volume } \\
\text { (cimento:cal:areia) }\end{array}$ & $\begin{array}{c}\text { Índice de } \\
\text { consistência }(\mathbf{m m})\end{array}$ & $\begin{array}{c}\text { Relação } \\
\text { água/cimento }\end{array}$ \\
\hline Argamassa & $1: 1,8: 3,6$ & 248,3 & 1,50 \\
\hline \hline
\end{tabular}

Fonte: Autor (2020).

Para os revestimentos em gesso, verificou-se o desempenho das pastas e das argamassas. As pastas de gesso são comumente utilizadas no Brasil e possuem grande aplicabilidade no mercado da construção civil. Por outro lado, as argamassas de gesso apresentam baixa frequência de utilização no país, inclusive com regulamentação dada apenas por códigos normativos internacionais, até o lançamento da ABNT NBR 16689:2019 (Gesso modificado - Métodos de ensaios) em novembro de 2019.

No entanto, a aplicação das argamassas de gesso se deve ao fato de que, conforme observado em trabalhos anteriores, os revestimentos em pasta de gesso não apresentaram comportamento satisfatório quando submetidos à elevação de temperatura, tendo em vista a grande retração manifestada pelo material devida à rápida perda de água, e posterior desprendimento do substrato de alvenaria em razão da baixa aderência residual.

Dessa maneira, trabalhos como John e Antunes (2002), Dolezelová et al. (2018) e Krejsová et al. (2018), consideram como benéfica a introdução de agregados nos revestimentos de gesso, sendo possível verificar um bom comportamento aderente devido à incorporação de partículas ásperas de agregados como a areia em substituição parcial às partículas de gesso. Além disso, esta substituição ainda pode ser vista como favorável do ponto de vista econômico e sustentável.

Em consequência da conotação científica e carência de trabalhos técnicos tratando sobre as argamassas de gesso, este item dará maior ênfase à discussão deste tipo de revestimento. Acrescenta-se que apenas uma mistura de revestimento em gesso será utilizada nos ensaios principais deste trabalho, porém, para tal utilização foi necessária a realização de ensaios prévios em diferentes traços, para que a opção pela utilização das pastas ou 
argamassas fosse fundamentada em uma justificativa consistente.

De modo geral, foram testadas uma composição de pasta e três composições de argamassas de gesso com inserção de areias com granulometrias fina e grossa. Para cada mistura, utilizaram-se três relações água/gesso (a/g) para avaliar os seus efeitos nas principais propriedades físicas e mecânicas dos revestimentos em gesso, totalizando 21 composições distintas.

A composição das misturas para as argamassas de gesso foi realizada de acordo com as prescrições da ASTM C28-10:2015, que recomenda que a proporção em massa de agregados presentes no gesso seja menor que 1:3 (gesso:areia). Dessa forma, as argamassas de gesso foram preparadas segundo três percentuais de areia $(50 \%, 100 \%$ e $200 \%)$ com relação ao gesso existente na mistura, portanto, com traços em massa de 1:0,5, 1:1 e 1:2 de gesso:areia.

Diante disso, verificou-se o comportamento dos revestimentos de gesso através de ensaios físicos de consistência e tempo de pega. A relação água/gesso foi ajustada de maneira que todas as composições apresentassem consistências de aproximadamente $150 \mathrm{~mm}, 250$ mm e $350 \mathrm{~mm}$, quando submetidas a 15 golpes na mesa de consistência com a velocidade de 1 golpe/s de acordo com o EN 13279-2:2014. A Figura 3.19 ilustra o a realização do ensaio de consistência em três diferentes composições de argamassa de gesso.

Figura 3.19 - Consistência das argamassas de gesso com composição (a) 1:0,5, a/g = 0,45, areia grossa (b) $1: 1, \mathrm{a} / \mathrm{g}=0,75$, areia fina e (c) $1: 2, \mathrm{a} / \mathrm{g}=1,10$, areia grossa

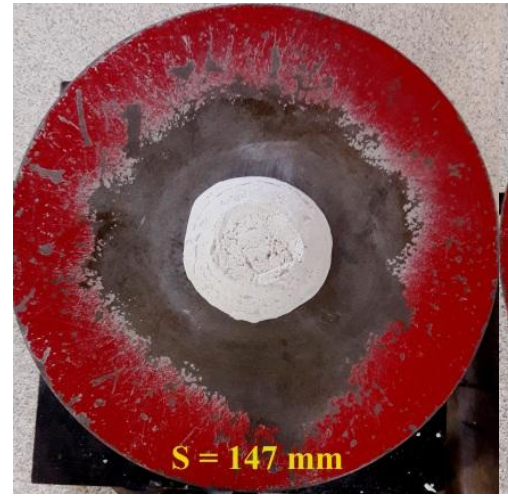

(a)

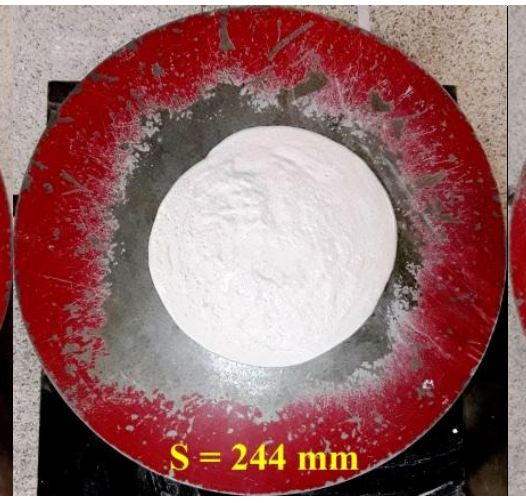

(b)

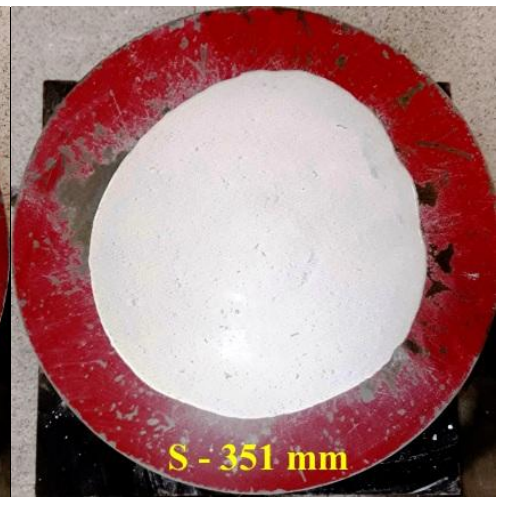

(c)

Fonte: Autor (2020).

A pasta e as argamassas de gesso foram preparadas pelo mesmo procedimento com auxílio de um misturador mecânico acionado em baixa velocidade durante aproximadamente um minuto, após serem polvilhadas lentamente na cuba pelo mesmo tempo. Para retirada e manuseio do material nos moldes, utilizou-se uma espátula metálica. O procedimento foi 
realizado conforme as recomendações da ABNT NBR 12129:2017 (Gesso para construção civil - Determinação das propriedades mecânicas) e EN 13279-2:2014.

Após a determinação da consistência para todas as misturas de gesso, realizou-se o ensaio para determinação do tempo de início e fim de pega da mistura, cujos resultados são apresentados na Tabela 3.15. Para ambas as determinações, empregou-se o aparelho de Vicat convencional, cujo procedimento é apresentado na Figura 3.20, sendo o tempo de início e fim de pega, respectivamente, aquele decorrido entre o instante em que o material entrou em contato com a água até o instante em que a agulha se posicionou a $1 \mathrm{~mm}$ da base e não mais penetrou na mistura.

Figura 3.20 - Procedimento para determinação do tempo de pega dos revestimentos em gesso
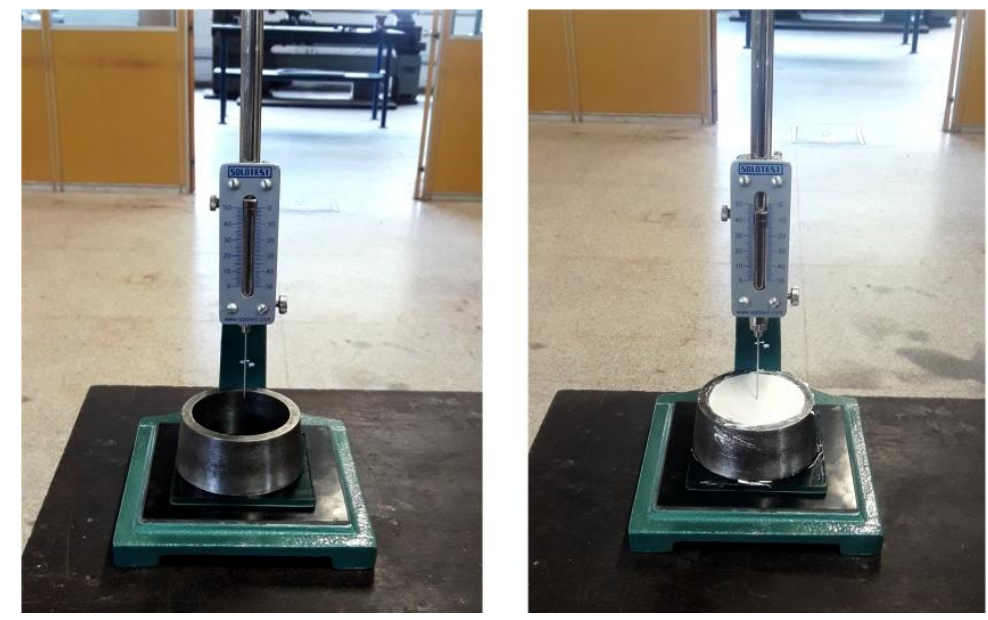

Fonte: Autor (2020).

Tabela 3.15 - Propriedades físicas das argamassas de gesso para revestimento

\begin{tabular}{|c|c|c|c|c|c|}
\hline Composição & Areia & $a / g$ & $\begin{array}{c}\text { Consistência } \\
(\mathbf{m m})\end{array}$ & $\begin{array}{c}\text { Início da pega } \\
\text { (min) }\end{array}$ & $\begin{array}{c}\text { Fim da pega } \\
(\text { min) }\end{array}$ \\
\hline \multirow{3}{*}{ Pasta } & - & 0,45 & 196,0 & $7: 50$ & $16: 30$ \\
\hline & - & 0,65 & 264,0 & $10: 20$ & $20: 10$ \\
\hline & - & 0,85 & 362,0 & $13: 10$ & $23: 30$ \\
\hline \multirow{6}{*}{$\begin{array}{c}\text { Argamassa } \\
1: 0,5\end{array}$} & Fina & 0,45 & 134,0 & $5: 30$ & $11: 50$ \\
\hline & & 0,65 & 234,0 & $8: 10$ & $15: 50$ \\
\hline & & 0,85 & 335,0 & $9: 40$ & $17: 30$ \\
\hline & Grossa & 0,45 & 147,0 & $5: 50$ & $13: 00$ \\
\hline & & 0,65 & 238,0 & $8: 40$ & $16: 50$ \\
\hline & & 0,85 & 331,0 & $11: 20$ & 20:00 \\
\hline \multirow{3}{*}{$\begin{array}{c}\text { Argamassa } \\
1: 1\end{array}$} & Fina & 0,55 & 148,0 & $6: 20$ & $13: 20$ \\
\hline & & 0,75 & 244,0 & $10: 20$ & $18: 50$ \\
\hline & & 0,95 & 379,0 & $11: 30$ & $21: 40$ \\
\hline
\end{tabular}

\section{Continua}


Conclusão

\begin{tabular}{cccccc}
\hline \hline Composição & Areia & a/g & $\begin{array}{c}\text { Consistência } \\
(\mathbf{m m})\end{array}$ & $\begin{array}{c}\text { Início da pega } \\
\text { (min) }\end{array}$ & $\begin{array}{c}\text { Fim da pega } \\
\text { (min) }\end{array}$ \\
\hline \hline \multirow{2}{*}{$\begin{array}{c}\text { Argamassa } \\
\mathbf{1 : 1}\end{array}$} & Grossa & 0,55 & 181,0 & $6: 30$ & $13: 40$ \\
& & 0,75 & 263,0 & $11: 10$ & $20: 10$ \\
& & 0,95 & 413,0 & $12: 00$ & $22: 20$ \\
\hline \multirow{2}{*}{ Argamassa } & \multirow{2}{*}{ Fina } & 0,70 & 169,0 & $7: 00$ & $13: 20$ \\
& & 0,90 & 251,0 & $9: 30$ & $17: 30$ \\
& \multirow{1}{*}{ Grossa } & 1,10 & 322,0 & $11: 50$ & $21: 40$ \\
& & 0,70 & 198,0 & $6: 50$ & $13: 10$ \\
& & 0,90 & 282,0 & $9: 00$ & $18: 00$ \\
\hline \hline
\end{tabular}

Fonte: Autor (2020).

A ABNT NBR 13207:2017 prescreve que o gesso utilizado como revestimento na construção civil deve apresentar tempo de pega inicial maior que 10 minutos, e que o fim da pega não deve ocorrer antes dos 35 minutos. Nesse contexto, observou-se que as composições com baixa consistência e relação água/gesso apresentaram pega antes do limite estabelecido e que em nenhum dos casos o tempo de endurecimento foi superior a 23,5 minutos. Observa-se através da Figura 3.21 e da Tabela 3.15 que esses fatores tiveram grande influência no tempo de pega das misturas, que foi maior conforme aumento da consistência.

Figura 3.21 -Variação do tempo de pega dos revestimentos em gesso de acordo com a consistência

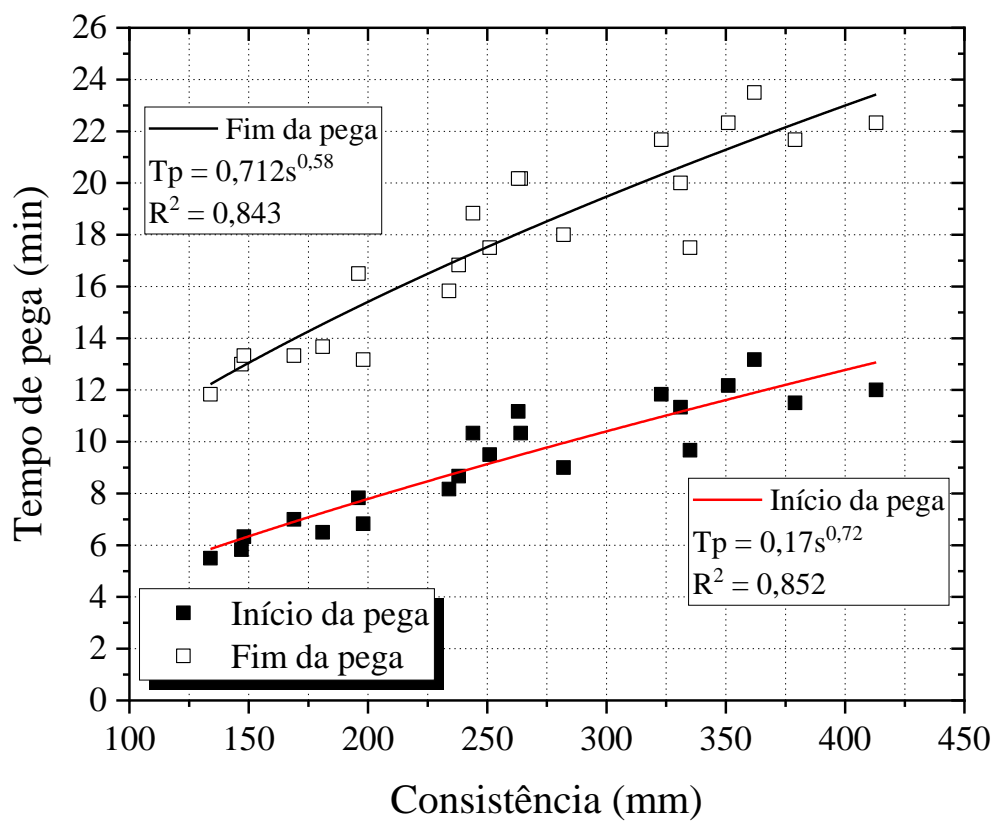

Fonte: Autor (2020).

De modo geral, para uma mesma composição e relação água/gesso, argamassas com 
areia fina apresentaram menor trabalhabilidade em relação a aquelas com presença de areia grossa, devido a maior capacidade de retenção de água em misturas com maior quantidade de partículas finas, que por sua vez possuem maior superfície específica (Figura 3.14), e consequentemente maior quantidade de água necessária para lubrificação da mistura.

$\mathrm{O}$ aumento do teor de agregados também apresentou influência significativa no tempo de pega das argamassas, que necessitaram de uma relação água/gesso superior para obtenção da mesma trabalhabilidade. John e Antunes (2002) atribuem esse fato à nucleação promovida pelos agregados, que acelera a precipitação da gipsita, produto a ser hidratado.

A caracterização dos revestimentos no estado endurecido foi realizada através de ensaios mecânicos para obtenção da resistência à compressão, flexão e aderência. Os ensaios de resistência à compressão e flexão foram desenvolvidos conforme as prescrições da ABNT NBR 13279:2005 (Argamassa para assentamento e revestimento de paredes e tetos Determinação da resistência à tração na flexão e à compressão) para a argamassa de cimento e EN 13279-2:2014 para os revestimentos em gesso.

Para cada tipo de revestimento foram moldados 3 corpos com dimensões 4,0 x 4,0 x $16,0 \mathrm{~cm}$, e os ensaios foram realizados controle de deslocamentos a uma velocidade de $0,005 \mathrm{~mm} / \mathrm{s}$ utilizando um equipamento servo-hidráulico Instron, modelo 23-200, e estrutura de compressão Emic AC6.08 com capacidade nominal de 2000 kN, disponível no Laboratório de Materiais e Construção Civil da Escola de Engenharia de São Carlos (LMCC - EESC).

Inicialmente, realizaram-se os ensaios de flexão em que os corpos de prova foram posicionados sobre dois roletes metálicos com diâmetro igual a $10 \mathrm{~mm}$ distanciados entre si de $100 \mathrm{~mm}$, enquanto aplicava-se uma carga de compressão através de um rolete metálico com as mesmas características posicionado no ponto médio da face superior dos corpos de prova. Em seguida, as metades dos corpos de prova restantes dos ensaios de flexão foram posicionadas entre duas chapas metálicas quadradas com $4,0 \mathrm{~cm}$ de lado e $1,25 \mathrm{~cm}$ de espessura para realização dos ensaios de compressão, conforme pode a Figura 3.22.

Figura 3.22 - Ensaios de flexão e compressão em argamassas para revestimento

Fonte: Autor (2020)
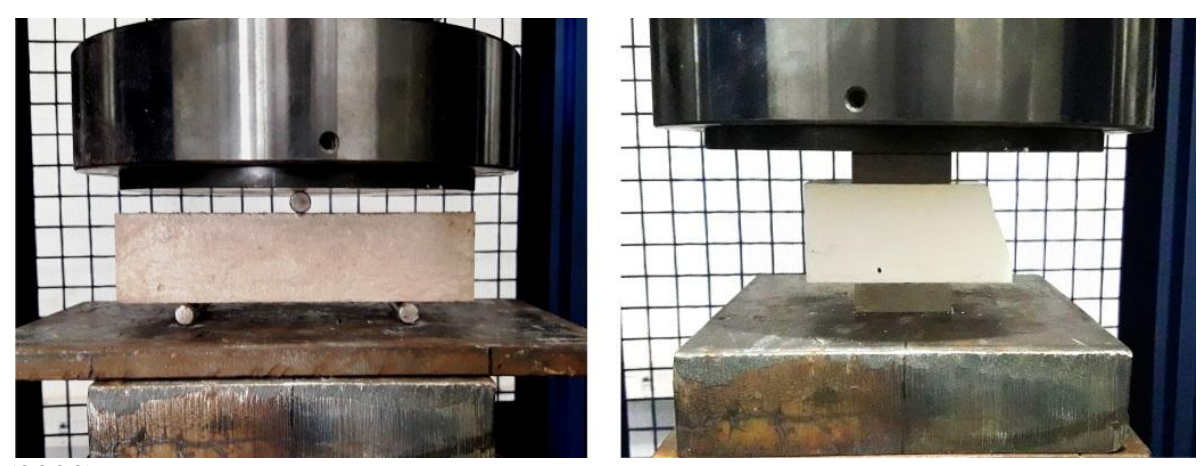
A argamassa de cimento para revestimento foi moldada conforme descrito no item 3.3.3, adensada em quatro camadas com 30 golpes manuais utilizando soquete metálico. Posteriormente, foram desmoldados após 48 horas e permaneceram durante 28 dias em câmara úmida até a data dos ensaios. As pastas e argamassas de gesso foram preparadas com auxílio de espátula, tiveram suas faces laterais pressionadas para evitar a presença de bolhas e foram rasados manualmente com uso de uma serra. Após o processo de moldagem, os corpos de prova foram desmoldados depois de 90 minutos e permaneceram em temperatura ambiente durante sete dias até submeterem-se à secagem em estufa com temperatura de $40 \pm 2{ }^{\circ} \mathrm{C}$ para obtenção de massa constante e posterior realização dos ensaios.

Para avaliação da aderência entre os revestimentos e os elementos de alvenaria estrutural realizaram-se ensaios de arrancamento à tração. Os ensaios foram executados conforme a EN 1015-12:2000, que estabelece recomendações para obtenção da tensão de aderência entre revestimentos e substratos de alvenaria. Para realização do ensaio utilizou-se um aparelho de arrancamento à tração disponível no Laboratório de Construção Civil do Instituto de Arquitetura (LCC - IAU), cinco pastilhas metálicas cilíndricas com $50 \mathrm{~mm}$ de diâmetro de $10 \mathrm{~mm}$ de espessura, uma serra-copo, um paquímetro com resolução de $0,01 \mathrm{~mm}$ e uma cola à base de resina epóxi para fixação das pastilhas metálicas no revestimento. $\mathrm{O}$ procedimento para realização do ensaio é ilustrado na Figura 3.23.

Figura 3.23 - Ensaio de aderência em argamassas para revestimento
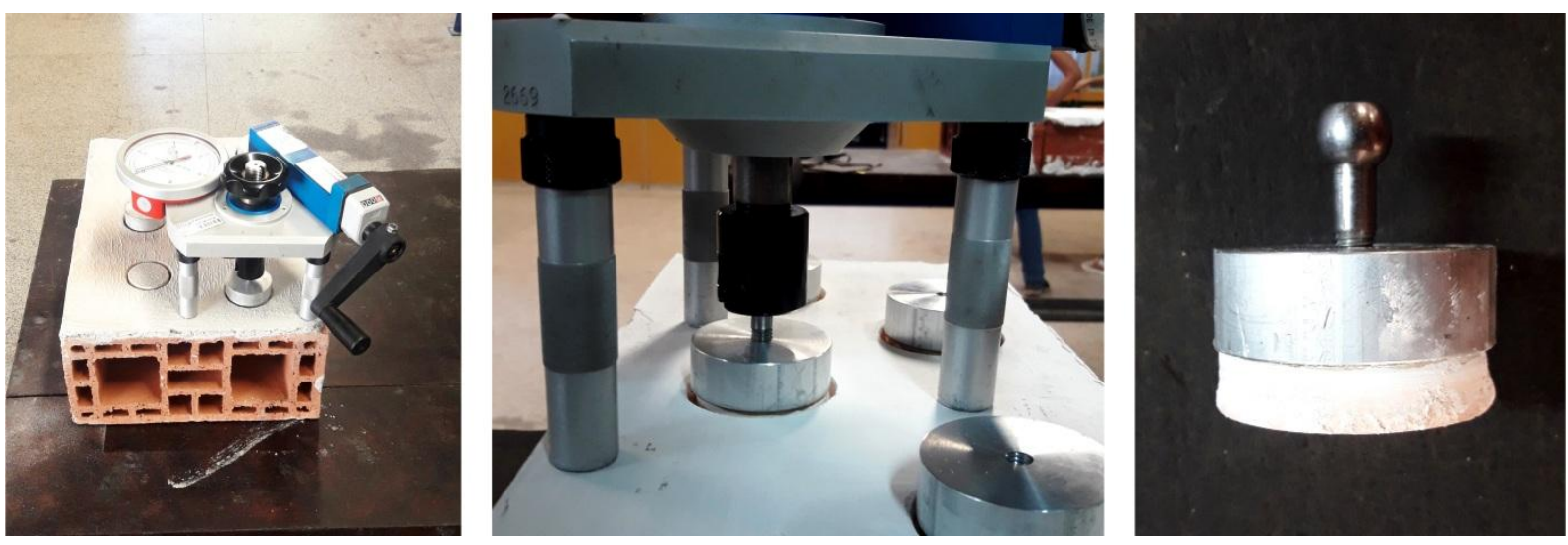

Fonte: Autor (2020).

Em cada uma das faces longitudinais de 11 prismas cerâmicos de dois blocos, aplicouse uma camada de revestimento com $10 \mathrm{~mm}$ de espessura de maneira sarrafeada, para cada mistura distinta de argamassa de cimento, pastas e argamassas de gesso. Cada ensaio foi composto por cinco corpos de prova (pastilhas metálicas) espaçados uniformemente entre si em $50 \mathrm{~mm}$. Fixaram-se as pastilhas metálicas com cola à base de resina epóxi, e o esforço de tração foi aplicado a uma taxa de 20 a 50 N/s perpendicularmente ao corpo de prova através 
de uma manivela manual acoplada ao equipamento, arrancando a pastilha metálica do substrato de alvenaria, com o valor da força de ruptura sendo obtido através da leitura realizada em um manômetro. A Tabela 3.16 exibe as propriedades mecânicas da argamassa de cimento.

Tabela 3.16 - Propriedades mecânicas da argamassa de cimento para revestimento

\begin{tabular}{cccc}
\hline & $\begin{array}{c}\text { Resistência à } \\
\text { compressão (MPa) }\end{array}$ & $\begin{array}{c}\text { Resistência à } \\
\text { flexão (MPa) }\end{array}$ & $\begin{array}{c}\text { Resistência à } \\
\text { aderência (MPa) }\end{array}$ \\
\hline \hline Média (MPa) & 4,76 & 1,64 & 0,31 \\
DP & 0,61 & 0,17 & 0,16 \\
CV (\%) & 12,78 & 10,61 & 51,28 \\
\hline \hline
\end{tabular}

Fonte: Autor (2020).

A Tabela 3.17 apresenta as propriedades mecânicas das argamassas de gesso, com o coeficiente de variação dado pela média dos coeficientes de variação de cada mistura. Exceto nas argamassas 1:2 e relação a/g igual a 1,10, todas as misturas atenderam as recomendações de resistência mínima à compressão de 2,8 MPa estabelecida pela ASTM C28-10:2015.

Tabela 3.17 - Propriedades mecânicas das argamassas de gesso para revestimento

\begin{tabular}{|c|c|c|c|c|c|}
\hline Composição & Areia & $\mathbf{a} / \mathbf{g}$ & $\begin{array}{c}\text { Resistência à } \\
\text { compressão (MPa) }\end{array}$ & $\begin{array}{l}\text { Resistência à } \\
\text { flexão (MPa) }\end{array}$ & $\begin{array}{c}\text { Resistência à } \\
\text { aderência (MPa) }\end{array}$ \\
\hline \multirow{3}{*}{ Pasta } & - & 0,45 & 15,41 & 5,97 & 0,24 \\
\hline & - & 0,65 & 11,35 & 4,46 & 0,47 \\
\hline & - & 0,85 & 6,21 & 3,07 & 0,54 \\
\hline \multirow{6}{*}{$\begin{array}{c}\text { Argamassa } \\
\text { 1:0,5 }\end{array}$} & Fina & 0,45 & 21,12 & 7,07 & 0,44 \\
\hline & & 0,65 & 11,32 & 4,31 & 0,23 \\
\hline & & 0,85 & 6,47 & 2,72 & 0,48 \\
\hline & Grossa & 0,45 & 21,52 & 6,18 & 0,52 \\
\hline & & 0,65 & 11,30 & 3,34 & 0,56 \\
\hline & & 0,85 & 6,78 & 2,33 & 0,72 \\
\hline \multirow{6}{*}{$\begin{array}{c}\text { Argamassa } \\
1: 1\end{array}$} & Fina & 0,55 & 16,32 & 4,87 & 0,69 \\
\hline & & 0,75 & 8,53 & 2,75 & 0,67 \\
\hline & & 0,95 & 4,66 & 1,75 & 0,56 \\
\hline & Grossa & 0,55 & 17,29 & 4,61 & 0,69 \\
\hline & & 0,75 & 10,13 & 2,79 & 0,68 \\
\hline & & 0,95 & 5,55 & 1,63 & 0,56 \\
\hline \multirow{3}{*}{$\begin{array}{c}\text { Argamassa } \\
1: 2\end{array}$} & Fina & 0,70 & 11,24 & 3,48 & 0,44 \\
\hline & & 0,90 & 6,84 & 1,69 & 0,50 \\
\hline & & 1,10 & 2,04 & 0,58 & 0,47 \\
\hline
\end{tabular}

Continua 
Conclusão

\begin{tabular}{cccccc}
\hline \hline Composição & Areia & $\mathbf{a} / \mathbf{g}$ & $\begin{array}{c}\text { Resistência à } \\
\text { compressão (MPa) }\end{array}$ & $\begin{array}{c}\text { Resistência à } \\
\text { flexão (MPa) }\end{array}$ & $\begin{array}{c}\text { Resistência à } \\
\text { aderência (MPa) }\end{array}$ \\
\hline \multirow{2}{*}{ Argamassa } & Grossa & 0,70 & 7,30 & 1,00 & 0,73 \\
$\mathbf{1 : 2}$ & & 0,90 & 3,32 & 0,46 & 0,76 \\
& & 1,10 & 2,51 & 0,38 & 0,48 \\
\hline CV $(\%)$ & - & - & 13,16 & 15,34 & 15,06 \\
\hline \hline
\end{tabular}

Fonte: Autor (2020).

Com exceção da resistência à aderência, que apresentou relativa variabilidade dos resultados e diferentes formas de ruptura, as demais propriedades mecânicas manifestaram uma redução na resistência mediante aumento da relação água/gesso, conforme a Figura 3.24.

Figura 3.24 - Influência da relação água/gesso nas resistências à (a) compressão (b) flexão e (c) aderência das argamassas de gesso para revestimento

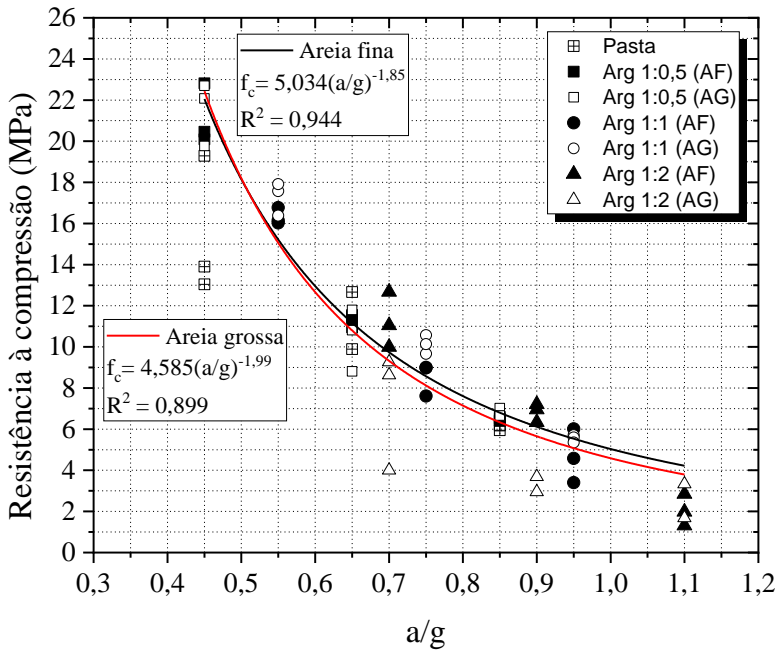

(a)

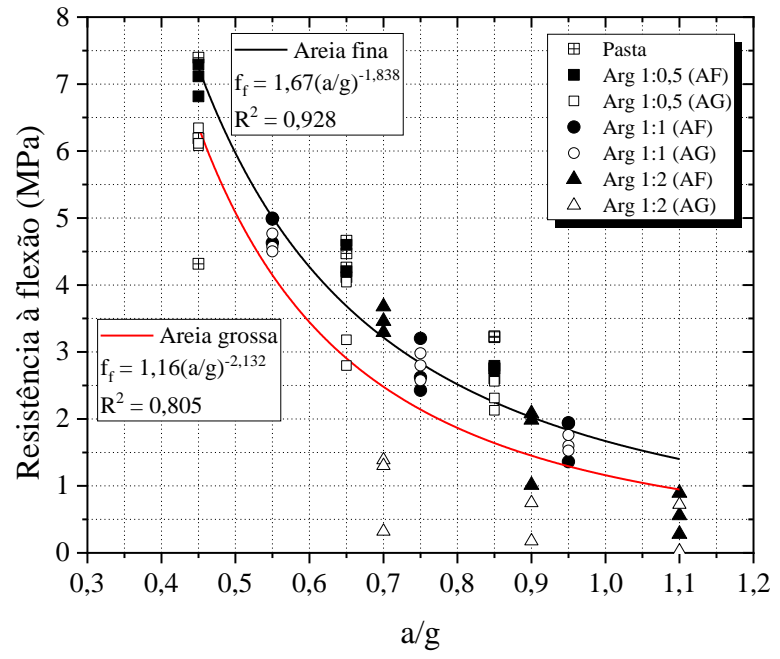

(b)

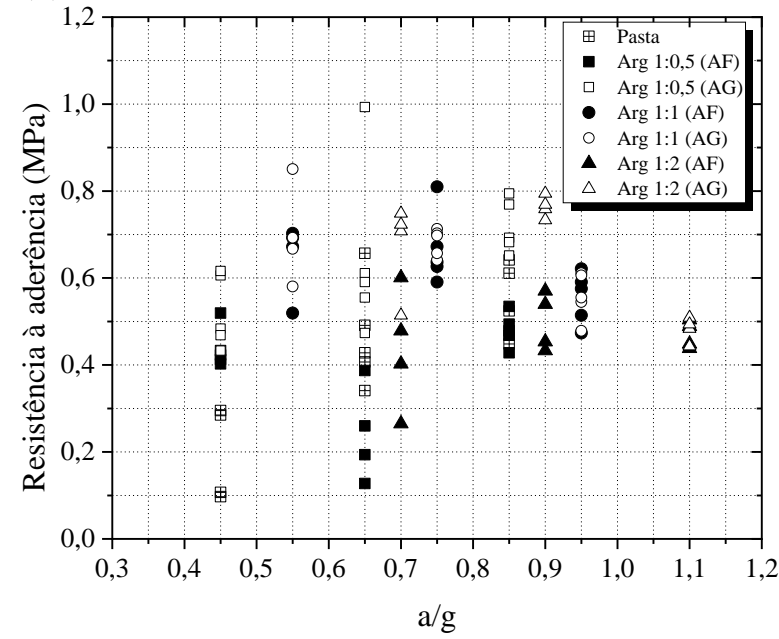

(c)

Fonte: Autor (2020).

A granulometria dos agregados apresentou baixo impacto na resistência à compressão, porém, argamassas constituídas de areia grossa obtiveram menor resistência à flexão, 
certamente devido à menor coesão das argamassas e aumento do volume de vazios promovido pela substituição dos aglomerantes por agregados de maior granulometria, como ilustrado na Figura 3.25. Uma boa relação linear entre as duas propriedades foi alcançada, conforme o coeficiente de determinação $\mathrm{R}^{2}$, e segue apresentada na Figura 3.26.

Figura 3.25 - Superfície de ruptura à flexão da (a) pasta, a/g = 0,45 (b) Argamassa 1:1, a/g = 0,55, areia fina e (c) Argamassa 1:2, a/g = 0,70, areia grossa

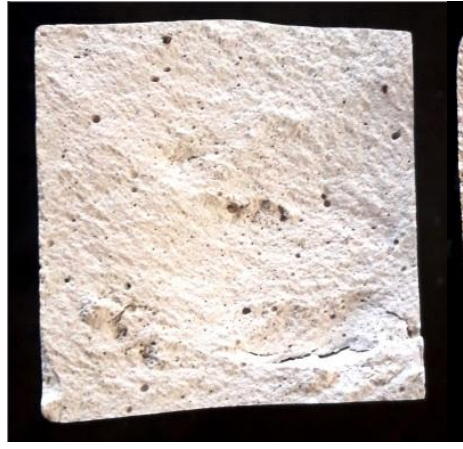

(a)

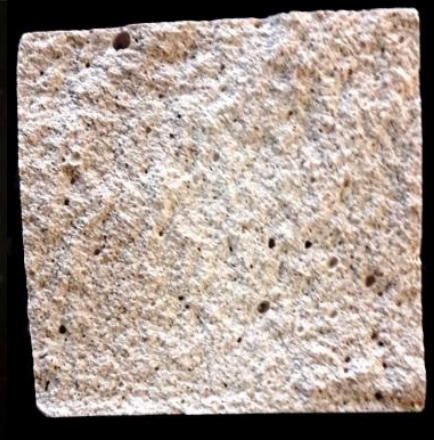

(b)

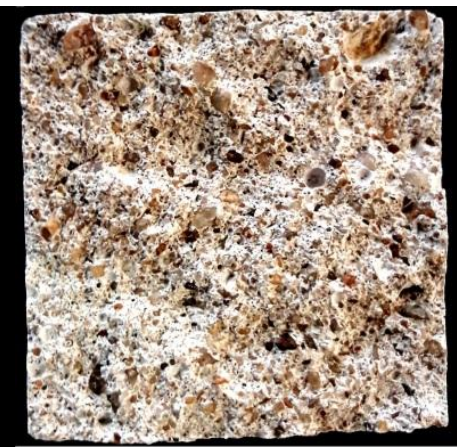

(c)

Fonte: Autor (2020).

Figura 3.26 - Relação entre a resistência à compressão e flexão para argamassas de gesso

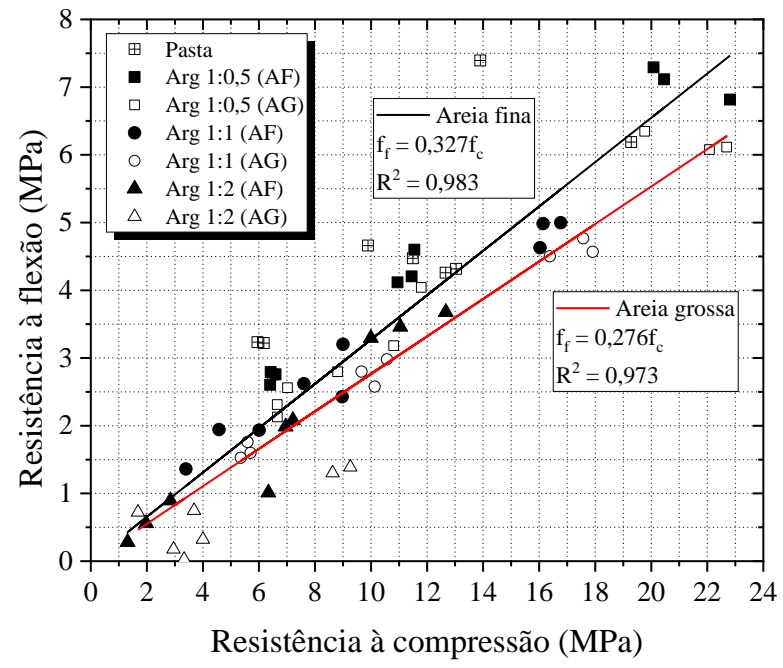

Fonte: Autor (2020).

\subsection{ELEMENTOS DE ALVENARIA ESTRUTURAL}

\subsubsection{Execução dos corpos de prova}

Como parte das etapas do programa experimental deste trabalho, realizou-se a caracterização dos elementos de alvenaria estrutural em temperatura ambiente para avaliação do comportamento mecânico dos mesmos. Para isso, foram ensaiados à compressão, prismas de dois blocos com 29 × $39 \mathrm{~cm}$, e pequenas paredes de cinco fiadas com 59 x $99 \mathrm{~cm}$ executadas utilizando os blocos e a argamassa especificados nos itens anteriores deste 
capítulo. O quantitativo e especificação dos ensaios realizados seguiram as recomendações da ABNT NBR 15812-3:2017 e estão indicados na Tabela 3.18.

Tabela 3.18 - Propriedades avaliadas nos elementos de alvenaria

\begin{tabular}{|c|c|c|c|}
\hline \multirow{2}{*}{$\begin{array}{l}\text { Tipo de } \\
\text { elemento }\end{array}$} & \multirow[b]{2}{*}{ Tipo de ensaio } & \multicolumn{2}{|c|}{ Quantidade de amostras } \\
\hline & & $\begin{array}{c}\text { Blocos com } \\
\text { paredes vazadas }\end{array}$ & $\begin{array}{c}\text { Blocos com } \\
\text { paredes maciças } \\
\end{array}$ \\
\hline Prismas & $\begin{array}{c}\text { Resistência à compressão e Módulo } \\
\text { de elasticidade }\end{array}$ & 6 & 6 \\
\hline $\begin{array}{l}\text { Pequenas } \\
\text { paredes }\end{array}$ & $\begin{array}{l}\text { Resistência à compressão e Módulo } \\
\text { de elasticidade }\end{array}$ & 3 & 3 \\
\hline
\end{tabular}

Fonte: Autor (2020).

Todos os prismas e pequenas paredes foram executados por um único operário, com auxílio de colher de pedreiro, nível e prumo, que se mantiveram verificados durante todo o processo de confecção. Em todos os corpos de prova utilizaram-se juntas de argamassamento total, com argamassa de assentamento especificada no item 3.3.3, com traço 1:0,5:4,5 em cimento, cal e areia fina, e espessura de $10 \mathrm{~mm}$ na horizontal e vertical.

Os prismas foram executados sobre peças de madeira posicionadas sob as paredes externas transversais dos mesmos, e as pequenas paredes de alvenaria estrutural foram moldadas sobre as bases de concreto armado projetadas para esta finalidade. Durante a execução, ambos os elementos foram verificados continuamente quanto ao nível, prumo e espessura das juntas de argamassa, e permaneceram à temperatura e umidade ambiente até a realização dos ensaios. A Figura 3.27 ilustra a execução destes elementos.

Figura 3.27 - Execução dos prismas e pequenas paredes de alvenaria estrutural
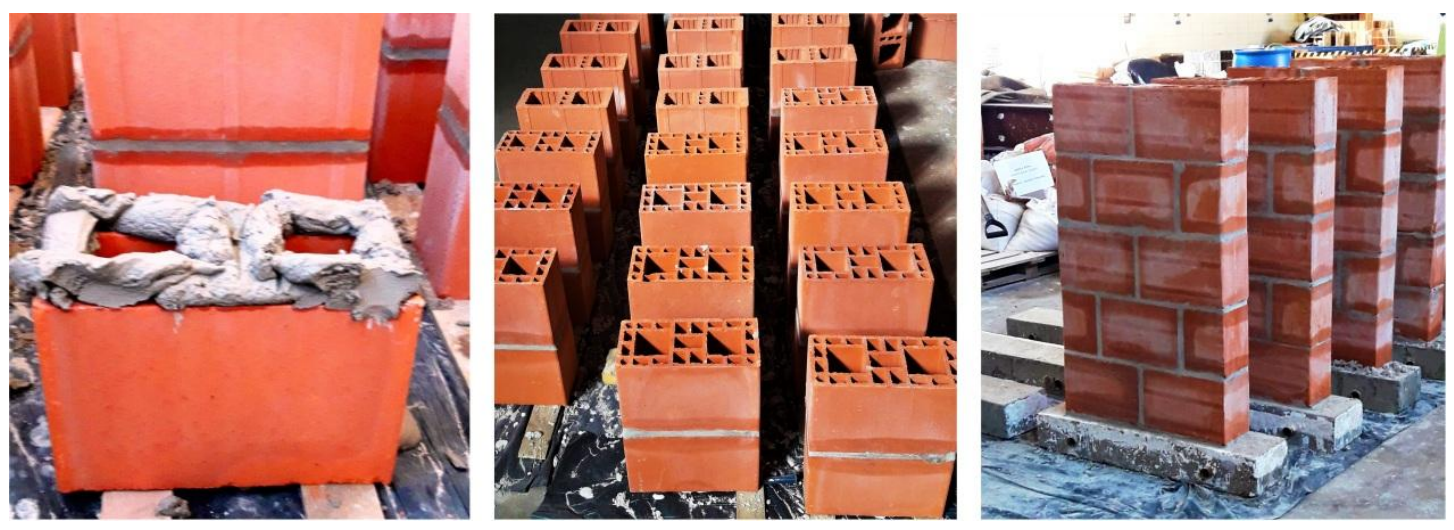

Fonte: Autor (2020).

Inicialmente, para facilitar o manuseio e transporte das pequenas paredes, executaramse bases de concreto armado com dimensões de $20 \mathrm{~cm}$ x $60 \mathrm{~cm}$ e espessura de $12 \mathrm{~cm}$. Na extremidade destes elementos foram posicionados dois tubos metálicos com $32 \mathrm{~mm}$ de 
diâmetro, para possibilitar o içamento dos mesmos junto com as pequenas paredes. As bases foram moldadas utilizando concreto convencional com traço 1:2,6:3,2 em massa para cimento, areia (40\% com granulometria fina e $60 \%$ com granulometria grossa) e brita 1 , com relação água/cimento igual a 0,58. Quanto às armaduras, empregou-se uma tela soldada Q 138 com barras de 4,20 mm de diâmetro espaçadas uniformemente a cada $10 \mathrm{~cm}$ em ambas as direções.

\subsubsection{Ensaios de compressão simples e módulo de elasticidade}

Os ensaios dos prismas e pequenas paredes de alvenaria estrutural foram realizados seguindo as prescrições da ABNT NBR 15812-3:2010 no Laboratório de Estruturas da Escola de Engenharia de São Carlos (LE - EESC).

Para obtenção da resistência à compressão, prismas e pequenas paredes foram ensaiados respectivamente em uma máquina Instron Satec ${ }^{\circledR}$, modelo $300 \mathrm{HVL}$ e capacidade nominal de $1500 \mathrm{kN}$, e em uma máquina Instron universal, modelo 8506 e capacidade nominal de $2500 \mathrm{kN}$. Ambos os elementos foram caracterizados com aplicação de controle de deslocamentos a uma velocidade de $0,02 \mathrm{~mm} / \mathrm{s}$ e tiveram as faces superior e inferior regularizadas com placas de forro constituído por fibra mineral, com o objetivo de evitar a concentração de tensões nos principais pontos de aplicação de carregamento, conforme apresentado na Figura 3.28.

Para aquisição do módulo de elasticidade, os prismas e pequenas paredes foram instrumentados com quatro transdutores de deslocamento com curso de $20 \mathrm{~cm}$ e $40 \mathrm{~cm}$, respectivamente, posicionados simetricamente nas duas faces longitudinais dos elementos.

Figura 3.28 - Ensaio de resistência à compressão em (a) prisma e (b) pequena parede

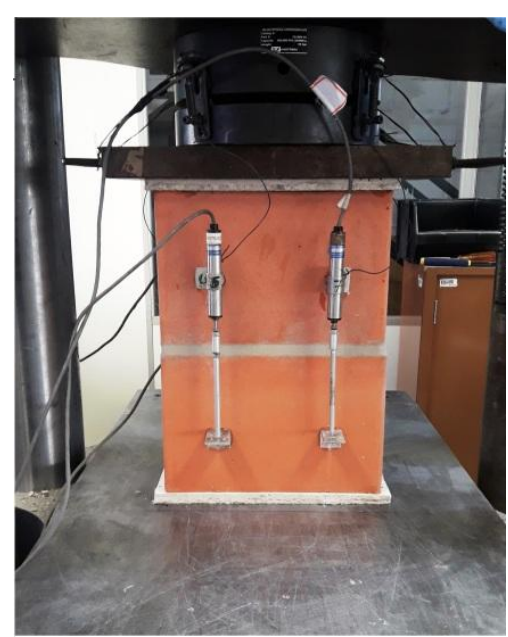

(a)

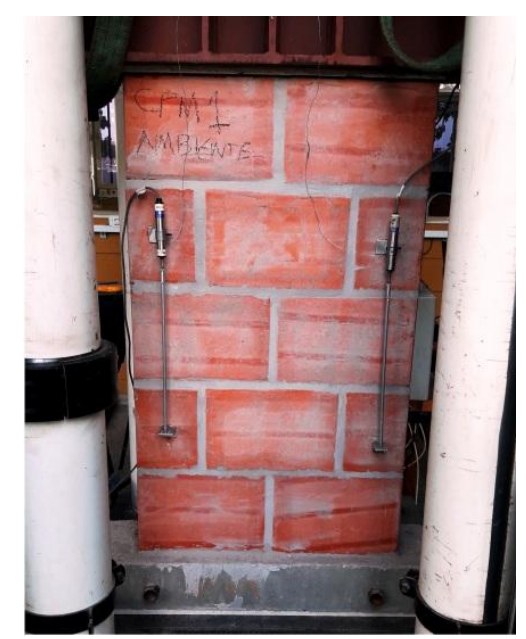

(b)

Fonte: Autor (2020). 
O módulo de elasticidade dos elementos foi calculado mediante prescrições do ACI 530-05:2005, que recomenda o cálculo do módulo de elasticidade secante admitindo como limites no diagrama tensão x deformação, os pontos inseridos entre $5 \%$ e $33 \%$ da tensão de ruptura. A Figura 3.29 apresenta os diagramas tensão x deformação para as duas geometrias de prismas avaliadas e na Tabela 3.19 são apontados os valores médios e característicos para a resistência à compressão e módulo de elasticidade dos prismas.

Figura 3.29 - Diagramas tensão x deformação dos prismas com blocos de paredes (a) vazadas e (b) maciças

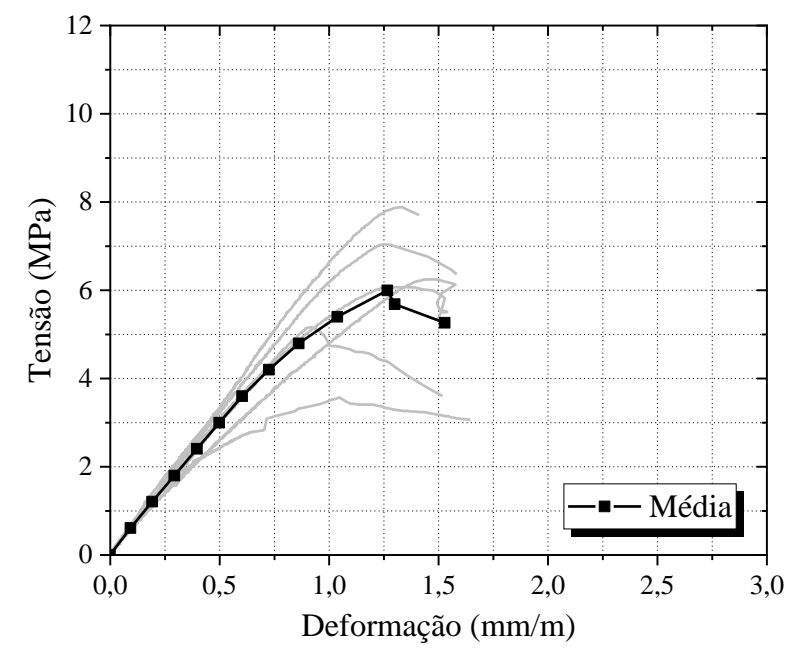

(a)

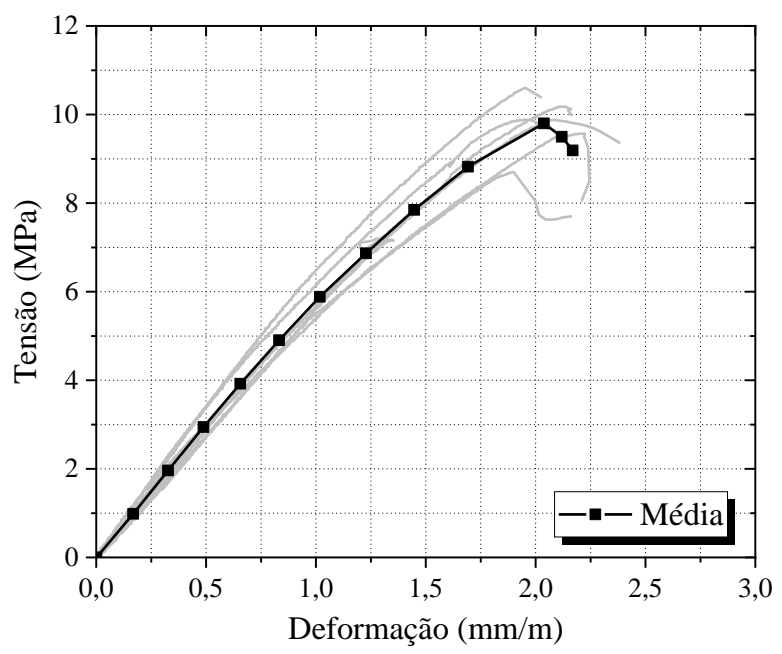

(b)

Fonte: Autor (2020).

Tabela 3.19 - Resistência à compressão e módulo de elasticidade dos prismas

\begin{tabular}{cccccc}
\hline \hline & $\begin{array}{c}\text { Força } \\
(\mathbf{k N})\end{array}$ & $\begin{array}{c}\text { Resistência na } \\
\boldsymbol{A}_{\text {bruta }}(\mathbf{M P a})\end{array}$ & $\begin{array}{c}\text { Resistência na } \\
\boldsymbol{A}_{\text {liq }}(\mathbf{M P a})\end{array}$ & $\begin{array}{c}\text { E na } \boldsymbol{A}_{\text {bruta }} \\
(\mathbf{G P a})\end{array}$ & $\begin{array}{c}\text { E na } \boldsymbol{A}_{\text {liq }} \\
(\mathbf{G P a})\end{array}$ \\
\hline \hline Média & 244,00 & 6,00 & 16,33 & 5,90 & 16,06 \\
DP & 61,12 & 1,50 & 4,08 & 0,57 & 1,55 \\
$\mathbf{C V}(\boldsymbol{\%})$ & 25,05 & 25,05 & 25,05 & 9,73 & 9,73 \\
$\mathbf{f}_{\mathbf{p k}}$ & - & 3,18 & 8,66 & - & - \\
\hline \hline & \multicolumn{5}{c}{ Prismas cerâmicos com blocos de paredes vazadas } \\
Média & 404,68 & 9,80 & 20,04 & 12,44 \\
DP & 26,47 & 0,64 & 1,31 & 6,08 & 1,08 \\
CV $(\boldsymbol{\%})$ & 6,54 & 6,54 & 6,54 & 0,53 & 8,79 \\
$\mathbf{f}_{\mathbf{p k}}$ & - & 8,39 & 8,79 & - \\
\hline \hline
\end{tabular}

Fonte: Autor (2020).

Da mesma forma, as pequenas paredes tiveram seus diagramas tensão x deformação determinados com auxílio dos transdutores e a Figura 3.30 ilustra esses resultados. Em seguida, a Tabela 3.20 descreve os resultados individuais para as propriedades mecânicas das 
pequenas paredes com os dois tipos de blocos utilizados.

Figura 3.30 - Diagramas tensão x deformação das pequenas paredes com blocos de paredes

(a) vazadas e (b) maciças

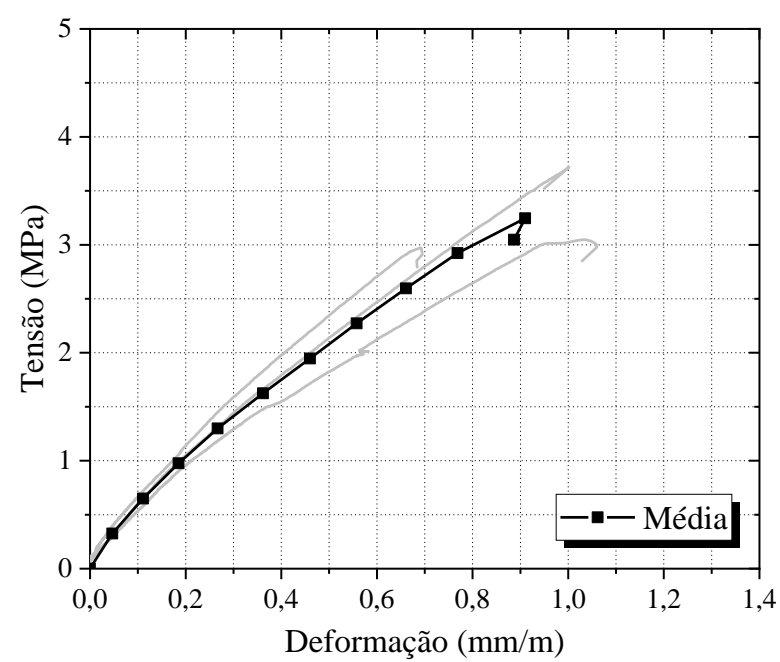

(a)

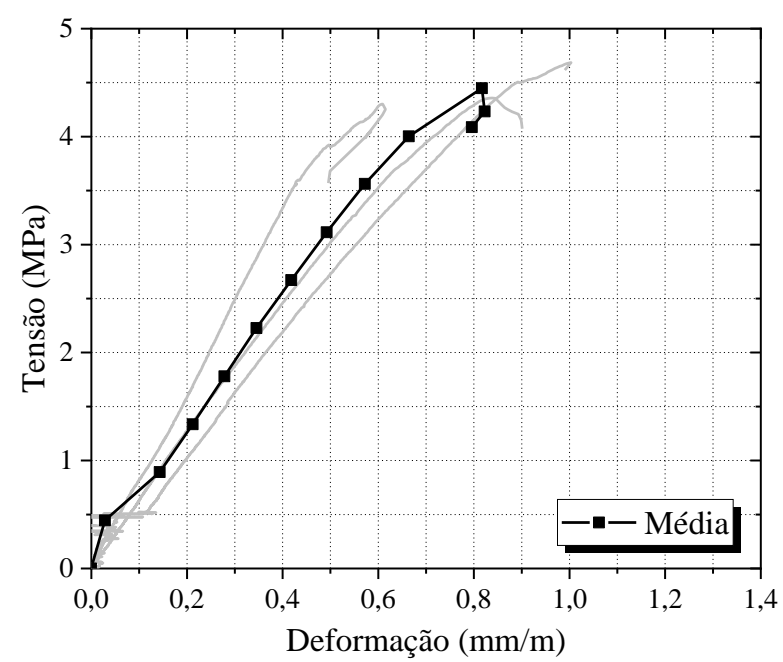

(b)

Fonte: Autor (2020).

Tabela 3.20 - Resistência à compressão e módulo de elasticidade de pequenas paredes

\begin{tabular}{cccccc}
\hline \hline & $\begin{array}{c}\text { Força } \\
(\mathbf{k N})\end{array}$ & $\begin{array}{c}\text { Resistência na } \\
\boldsymbol{A}_{\text {bruta }}(\mathbf{M P a})\end{array}$ & $\begin{array}{c}\text { Resistência na } \\
\boldsymbol{A}_{\text {liq }}(\mathbf{M P a})\end{array}$ & $\begin{array}{c}\text { E na } \boldsymbol{A}_{\text {bruta }} \\
(\mathbf{G P a})\end{array}$ & $\begin{array}{c}\text { E na } \boldsymbol{A}_{\text {liq }} \\
(\mathbf{G P a})\end{array}$ \\
\hline \hline Média & 268,70 & 3,25 & 8,86 & 4,71 & 12,46 \\
DP & 34,03 & 0,41 & 1,08 & 0,53 & 1,40 \\
$\mathbf{C V}(\boldsymbol{\%})$ & 12,66 & 12,66 & 12,66 & 11,16 & 11,16 \\
$\mathbf{f}_{\text {ppk }}$ & - & 2,38 & 6,29 & - & - \\
\hline \hline & \multicolumn{5}{c}{ Pequenas paredes com blocos de paredes vazadas } \\
\hline Média & 373,56 & 4,45 & 8,94 & 6,32 & 12,70 \\
DP & 17,47 & 0,21 & 0,42 & 1,36 & 2,73 \\
CV $(\%)$ & 4,68 & 4,68 & 4,68 & 21,45 & 21,45 \\
$\mathbf{f}_{\text {ppk }}$ & - & 3,44 & 6,91 & - & - \\
\hline \hline
\end{tabular}

Fonte: Autor (2020).

O modo de ruptura dos prismas foi governado principalmente pelo esmagamento da junta de argamassa de assentamento, com posterior fendilhamento dos blocos na região da interface, e ocorreu de maneira brusca em alguns prismas com blocos de paredes maciças, como pode ser visto na Figura 3.31. Segundo Mohamad (1998), a baixa resistência e maior deformabilidade da argamassa em relação aos blocos promove uma expansão lateral da junta, ocasionando o surgimento de tensões de tração em alguns pontos dos blocos próximos a interface, provocando o esfacelamento dos blocos e aparecimento de fissuras. Comportamento semelhante de ruptura em prismas cerâmicos também foi observado em Rizzatti et al. (2012) e 
Mendes (1998).

Figura 3.31 - Modo de ruptura dos prismas
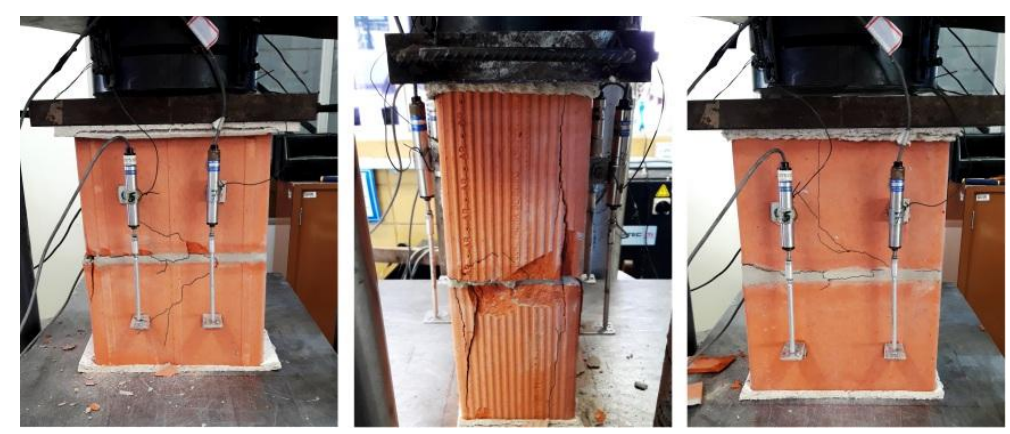

Fonte: Autor (2020).

As pequenas paredes tiveram o início da ruptura caracterizado pelo surgimento de fissuras nas juntas vertical e horizontal da última fiada, que se propagaram ao longo da parede interceptando os blocos. Em casos esporádicos também se observou a presença de fissuras verticais devido às tensões de tração nas faces laterais dos elementos, conforme apresentado na Figura 3.32.

Figura 3.32 - Modo de ruptura das pequenas paredes
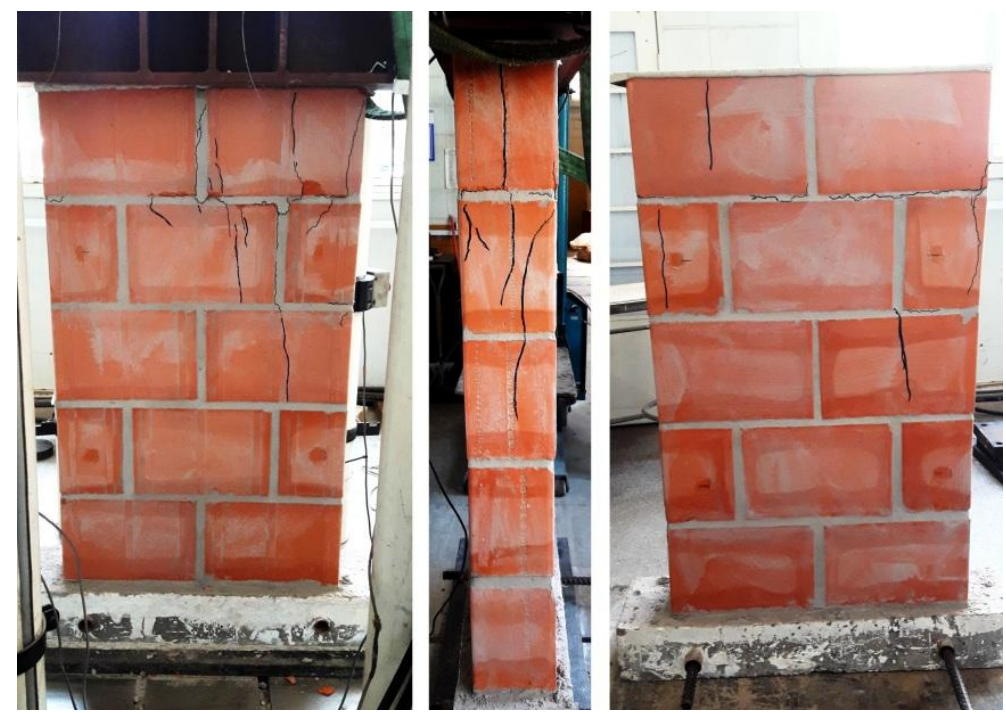

Fonte: Autor (2020).

\subsection{EFICIÊNCIA DA ALVENARIA ESTRUTURAL}

Os fatores de eficiência são importantes aspectos no contexto teórico-prático para avaliação dos elementos de alvenaria estrutural, uma vez que descrevem de maneira simples a relação entre as propriedades mecânicas dos diferentes elementos.

Em geral, as unidades e os elementos de alvenaria constituídos por blocos de paredes maciças apresentaram maior resistência mecânica em relação a aqueles com blocos de paredes 
vazadas. Em média, essa diferença foi de $16 \%, 68 \%, 63 \%$ e $37 \%$ para blocos, meio-blocos, prismas e pequenas paredes, respectivamente. Quanto à resistência à tração na área líquida, os blocos apresentaram 3,97\% e 5,50\% de resistência à tração em relação à resistência à compressão, respectivamente, para as unidades com paredes vazadas e maciças.

Blocos e meio-blocos cerâmicos apresentaram variações de 13,6\% e 32,5\% para o módulo de elasticidade das unidades com paredes vazadas e maciças, respectivamente. A princípio, como o conjunto das unidades deve ser tratado como mesmo material, considerouse esta variação elevada. No entanto, essa diferença pode ser explicada tendo em vista que não há um consenso no meio técnico-científico para obtenção do módulo de elasticidade do material, mediante a grande possibilidade de variação desta propriedade devido à geometria das unidades, que dificulta a avaliação do módulo efetivo do material cerâmico que compõe as mesmas.

A Tabela 3.21 apresenta os fatores de eficiência da alvenaria estrutural referentes às relações entre prisma/bloco, pequena parede/bloco e pequena parede/prisma quanto as suas respectivas resistências à compressão na área bruta. Destaca-se que para evitar distorções quanto aos fatores de eficiência devido à maior variabilidade de resultados entre os diferentes elementos, tais fatores foram calculados de acordo com as resistências médias.

Tabela 3.21 - Eficiência da alvenaria estrutural em temperatura ambiente

\begin{tabular}{cccc}
\hline \hline Tipo de bloco & $\mathbf{f}_{\mathbf{p}} / \mathbf{f}_{\mathbf{b}}$ & $\mathbf{f}_{\mathbf{p p}} / \mathbf{f}_{\mathbf{b}}$ & $\mathbf{f}_{\mathbf{p p}} / \mathbf{f}_{\mathbf{p}}$ \\
\hline $\begin{array}{c}\text { Unidades com paredes } \\
\text { vazadas }\end{array}$ & 0,58 & 0,32 & 0,54 \\
$\begin{array}{c}\text { Unidades com paredes } \\
\text { maciças }\end{array}$ & 0,82 & 0,37 & 0,45 \\
\hline
\end{tabular}

Fonte: Autor (2020).

\subsection{RESUMO DO CAPÍTULO}

Neste capítulo foram apresentadas as principais informações e resultados acerca da caracterização dos materiais e dos elementos de alvenaria estrutural. Unidades cerâmicas de alvenaria estrutural foram caracterizadas através de duas geometrias de blocos e meio-blocos quanto às suas propriedades geométricas, físicas e mecânicas. Argamassas de assentamento e revestimento tiveram seus aglomerantes e agregados caracterizados através de ensaios de composição química e microscopia eletrônica por varredura, sendo posteriormente analisadas nos estados fresco e endurecido. Elementos de alvenaria tiveram suas propriedades mecânicas avaliadas a partir de ensaios de resistência à compressão e módulo de elasticidade em prismas 
de dois blocos e pequenas paredes.

As unidades cerâmicas não apresentaram diferenças significativas quanto às propriedades geométricas e físicas, com exceção da relação entre as áreas líquida e bruta que variaram de $36,7 \%$ a $48,9 \%$ entre os blocos e $41,3 \%$ a $58,1 \%$ entre os meio-blocos. O comportamento mecânico de todas as unidades foi avaliado através de ensaios de resistência à compressão, resistência à tração e módulo de elasticidade, destacando-se o comportamento extremamente frágil na ruptura, o que impossibilitou a obtenção do trecho pós-pico dos diagramas tensão x deformação, e a baixa resistência à tração do material.

A partir de um extenso programa experimental para as argamassas de assentamento e revestimento, observou-se que a argamassa de assentamento apresentou resistência inferior à estimada, devido à incorporação de um elevado fator água/cimento para obtenção de consistência adequada para manuseio e utilização. Ao mesmo tempo, argamassas de gesso para revestimento foram avaliadas segundo o teor e granulometria dos agregados, e relação água/gesso presente na mistura.

As argamassas de gesso tiveram sua trabalhabilidade e tempo de pega reduzido conforme aumento do teor de agregados na mistura, sendo necessária uma maior relação água/gesso para aquisição de mesma trabalhabilidade e intervalo de endurecimento. Analisaram-se as propriedades mecânicas a partir de resultados de resistência à compressão, flexão e aderência. A granulometria dos agregados apontou variações pequenas na resistência à compressão, porém, agregados de maior granulometria favoreceram a diminuição da resistência à flexão e aumento da resistência a aderência.

Prismas e pequenas paredes apresentaram ruptura regida inicialmente pelo esmagamento da junta de argamassa de assentamento, e comportamento frágil na ruína. Em geral, todas as unidades e elementos considerados apresentaram maior resistência quando constituídos por unidades cerâmicas de paredes maciças. Ao mesmo tempo, os fatores de eficiência destes elementos foram superiores, com exceção da pequena parede/prisma.

Finalmente, destaca-se que esta etapa compreendeu uma importante fase do trabalho, com informações fundamentais para a análise dos resultados experimentais obtidos posteriormente, além de apresentar as principais propriedades que poderão subsidiar modelos numéricos, e facilitar o entendimento do comportamento e dos fenômenos presentes nos elementos de alvenaria. 


\section{PROGRAMA EXPERIMENTAL II - SIMULAÇÕES DE INCÊNDIO-PADRÃO}

\subsection{CONSIDERAÇÕES INICIAIS}

Para avaliação do comportamento térmico dos elementos estruturais de alvenaria, realizaram-se ensaios para simulação de incêndio seguindo a curva de incêndio-padrão proposta pela ISO 834-1:1999, previamente apresentada no item 2.3.2.3. Nesse mesmo contexto, blocos, prismas e pequenas paredes de alvenaria estrutural com blocos cerâmicos foram sujeitos à elevação de temperatura através de três ensaios de incêndio-padrão.

Os corpos de prova foram submetidos à simulação de incêndio-padrão através de um forno horizontal a gás disponível no Laboratório de Estruturas da Escola de Engenharia de São Carlos (LE - EESC). O equipamento utilizado apresenta funcionamento através de gás natural, possui dimensões de $3,0 \times 4,0 \times 1,5 \mathrm{~m}$ e dispõe de oito queimadores que são acionados através de uma central de comando, com evolução da temperatura controlada por nove termopares principais que são posicionados internamente ao equipamento no instante do ensaio, conforme ilustrado na Figura 4.1.

Figura 4.1 - Forno horizontal a gás

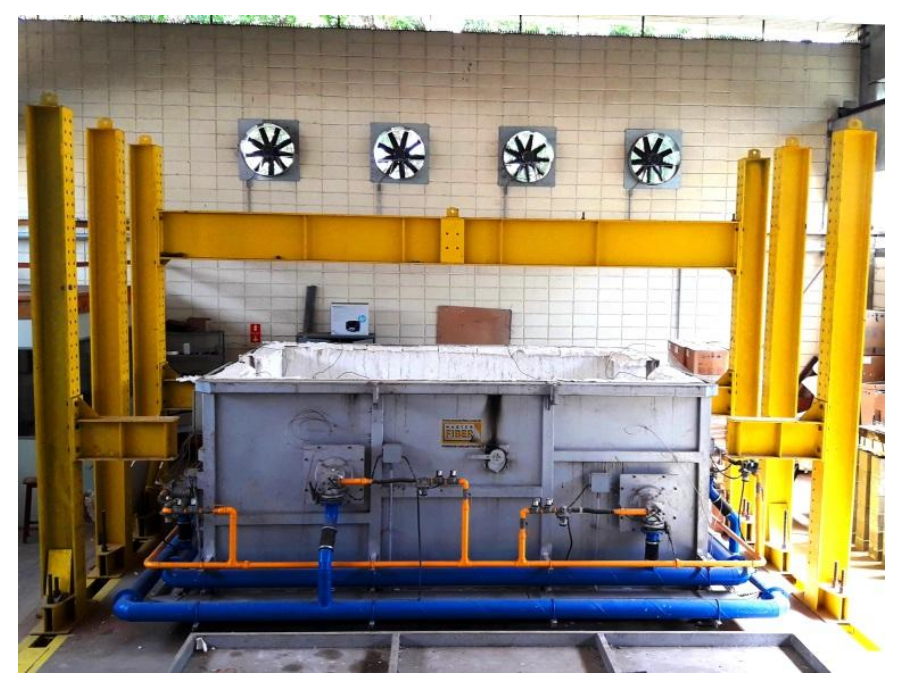

Fonte: Autor (2020).

Assim, este capítulo destina-se à descrição e apresentação dos ensaios realizados em temperaturas elevadas com simulação de incêndio-padrão. A seguir, apresentaram-se os principais detalhes quanto à execução e quantidade de corpos de prova submetidos à elevação de temperatura, assim como as particularidades relativas aos ensaios de incêndio-padrão, como organização do ensaio e instrumentação. Além disso, investigou-se o desenvolvimento do campo térmico e isolamento proporcionado pelos elementos de alvenaria. 


\subsection{EXECUÇÃO DOS CORPOS DE PROVA}

A execução dos corpos de prova foi realizada de maneira similar e utilizando os mesmos materiais descritos no capítulo 3. Embora os códigos normativos não especifiquem a quantidade de ensaios para este tipo de avaliação, utilizou-se o mesmo número de corpos de prova empregado na caracterização dos materiais em temperatura ambiente para cada situação analisada, seguindo as recomendações da ABNT NBR 15270-1:2017 para os blocos cerâmicos, ABNT NBR 13279:2005 para as argamassas de assentamento e ABNT NBR 15812-3:2017 para os prismas e pequenas paredes de alvenaria.

A Tabela 4.1 especifica a quantidade de corpos de prova submetidos à elevação de temperatura. A variação do quantitativo justifica-se pelo fato de que as pequenas paredes foram avaliadas perante diferentes condições de ensaio, com uma ou duas faces sujeitas à ação do fogo e com alternância de revestimentos, que por sua vez foram aplicados apenas nas pequenas paredes com blocos de paredes vazadas. Além disso, com o intuito inicial de verificar os impactos da ação do fogo na aderência de revestimentos distintos, utilizaram-se dez prismas com blocos de paredes maciças.

Tabela 4.1 - Propriedades avaliadas dos elementos em situação de incêndio

\begin{tabular}{|c|c|c|c|}
\hline \multirow{2}{*}{$\begin{array}{l}\text { Tipo de } \\
\text { elemento }\end{array}$} & \multirow[b]{2}{*}{ Tipo de ensaio } & \multicolumn{2}{|c|}{ Quantidade de amostras } \\
\hline & & $\begin{array}{c}\text { Blocos com } \\
\text { paredes vazadas } \\
\end{array}$ & $\begin{array}{c}\text { Blocos com } \\
\text { paredes maciças } \\
\end{array}$ \\
\hline Blocos & $\begin{array}{l}\text { Resistência à compressão e Módulo } \\
\text { de elasticidade }\end{array}$ & 13 & 13 \\
\hline \multirow{2}{*}{ Prismas } & $\begin{array}{l}\text { Resistência à compressão e Módulo } \\
\text { de elasticidade }\end{array}$ & 6 & 6 \\
\hline & $\begin{array}{l}\text { Aderência de revestimento sob ação } \\
\text { do fogo }\end{array}$ & - & 10 \\
\hline $\begin{array}{l}\text { Pequenas } \\
\text { paredes }\end{array}$ & $\begin{array}{c}\text { Resistência à compressão e Módulo } \\
\text { de elasticidade }\end{array}$ & 15 & 9 \\
\hline
\end{tabular}

Fonte: Autor (2020).

Os prismas e pequenas foram executados utilizando-se argamassa de assentamento com traço 1:0,5:4,5 (cimento:cal:areia fina) em volume e relação água/cimento igual a 1,50, com junta de argamassamento total de $10 \mathrm{~mm}$ de espessura, conforme especificado no item 3.3.3, e foram verificados no decorrer da sua confecção com auxílio de nível e prumo.

Para o revestimento, empregaram-se as composições especificadas no item 3.3.4, cuja execução foi realizada com o auxílio de duas guias laterais para permitir uma maior 
uniformidade e garantir a espessura dos mesmos, como pode ser visto na Figura 4.2. Deste modo, os elementos revestidos com argamassa de cimento foram previamente envolvidos com aplicação de chapisco com traço 1:3 (cimento:areia fina) em volume e relação água/cimento igual a 0,90, preparados através de um misturador mecânico de eixo inclinado.

Quanto aos revestimentos em gesso, utilizou-se um recipiente com água, com posterior polvilhamento do material e retirada com espátula conforme utilização. Para ambos os tipos de revestimento, a espessura final foi de $10 \mathrm{~mm}$ em todas as faces, e sua aplicação nos ensaios ocorreu com tempo superior a 28 dias da execução. Dentre os revestimentos com argamassas gesso, destaca-se que devido ao melhor acabamento superficial e baixo prejuízo na resistência à aderência, conforme a Tabela 3.17, apenas as composições com emprego de areia fina foram efetivamente utilizadas nos elementos estruturais de alvenaria.

Figura 4.2 - Execução do revestimento nos elementos de alvenaria
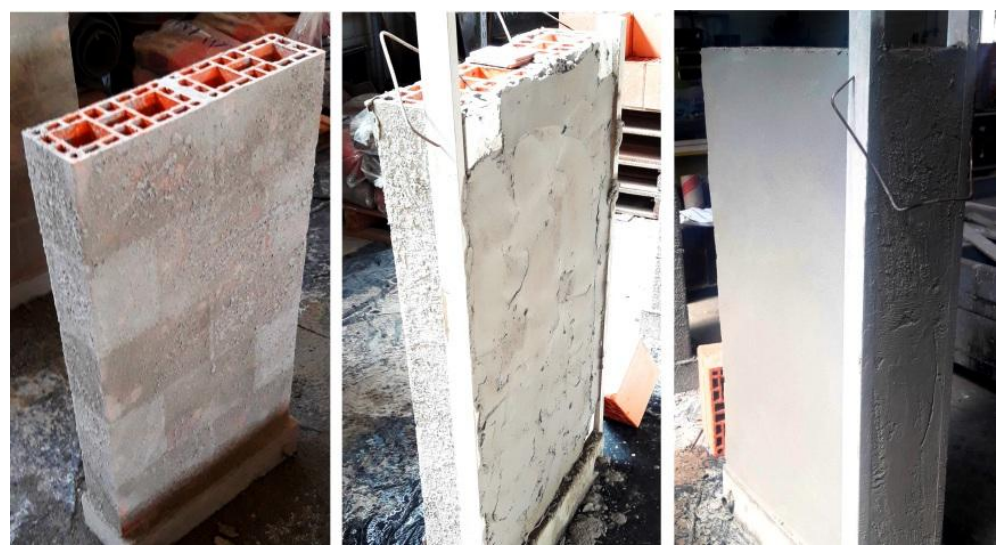

Fonte: Autor (2020).

Ademais, para a avaliação do fenômeno da reidratação das argamassas de cimento após submissão à elevação de temperatura e posterior exposição à temperatura ambiente, e verificação da influência do teor de agregados das argamassas de gesso na transferência de calor do material, confeccionou-se 30 corpos de prova cilíndricos 5 x $10 \mathrm{~cm}$ de argamassa de assentamento para realização de ensaios de compressão simples e módulo de elasticidade em três diferentes idades após ensaio de incêndio-padrão (1, 3 e 7 dias), e seis corpos de prova com mesma dimensão de dois tipos de revestimento em gesso para análise puramente térmica.

\subsection{ORGANIZAÇÃO DOS ENSAIOS}

A distribuição dos corpos de prova no forno foi realizada visando uma maior uniformidade, observando-se a presença de gases quentes em regiões concentradas do equipamento. Desta forma, os elementos foram distribuídos de maneira homogênea, evitando 
o posicionamento dos corpos de prova em zonas próximas aos queimadores, onde poderia ocorrer o contato direto entre as chamas e o corpo de prova. Os termopares para controle da evolução de temperatura no forno também foram dispostos buscando o desenvolvimento da temperatura interna de forma semelhante em todas as regiões do forno.

Neste trabalho, os ensaios individuais realizados no forno para simulação de incêndiopadrão foram denominados como fornadas, ou seja, circunstância pela qual os materiais ou elementos foram destinados ao forno para submeterem-se a uma elevação de temperatura.

\subsubsection{Fornada I}

Para realização de uma avaliação prévia do comportamento de alguns componentes da alvenaria estrutural com blocos cerâmicos sujeitos a ação de altas temperaturas, verificação de detalhes referentes à instrumentação, e averiguação a respeito do desempenho dos diferentes tipos de revestimentos mencionados no capítulo 3 , realizou-se o primeiro ensaio para simulação de incêndio-padrão.

Embora a primeira fornada tenha sido realizada com caráter exploratório, devido ao custo financeiro para realização do ensaio, optou-se também por submeter ao mesmo, os blocos cerâmicos de alvenaria com paredes vazadas e maciças, para uma avaliação inicial quanto ao comportamento mecânico residual e elevação de temperatura nas respectivas seções transversais. Além disso, a argamassa de assentamento e dois tipos de revestimento em gesso também foram avaliados quanto ao comportamento mecânico e térmico, respectivamente. A Tabela 4.2 apresenta a descrição de todos os corpos de prova ensaiados na fornada I.

Tabela 4.2 - Quantidade e especificação dos corpos de prova da fornada I

\begin{tabular}{ccc}
\hline $\begin{array}{c}\text { Tipo de corpo de } \\
\text { prova }\end{array}$ & Especificação & Quantidade \\
\hline \hline Blocos & Com paredes vazadas & 13 \\
& Com paredes maciças & 13 \\
\hline \multirow{2}{*}{ Prismas revestidos } & Argamassa de cimento 1:3, com a/c =1,50 & 2 \\
& Pasta de gesso, com a/g $=0,45$ & 2 \\
& Argamassa de gesso $1: 0,5$, com a/g $=0,45$ e areia fina & 2 \\
\hline $\begin{array}{c}\text { Argamassa de } \\
\text { assentamento }\end{array}$ & Argamassa de gesso $1: 2$, com a/g $=0,70$ e areia fina & 2 \\
\hline $\begin{array}{c}\text { Argamassas de } \\
\text { revestimento }\end{array}$ & Argamassa de gesso $1: 2$, com a/g $=0,5: 4,5$, com a/c $=1,50$ & 30 \\
\hline \hline
\end{tabular}

Fonte: Autor (2020). 
Antes da realização do ensaio, verificaram-se as umidades relativas de ambos os blocos, devido à sua relevância no comportamento térmico dos elementos, no que diz respeito à liberação da água dos poros do material durante a etapa de aquecimento. Obtiveram-se as umidades relativas mediante comparação entre a massa seca apresentada na Tabela 3.6, e a massa das amostras imediatamente antes da realização da fornada.

Tabela 4.3 - Temperatura ambiente e umidade relativa dos corpos de prova da fornada I

\begin{tabular}{ccc}
\hline Unidade & Umidade relativa & $\begin{array}{c}\text { Temperatura } \\
\text { ambiente }\end{array}$ \\
\hline \hline Blocos com paredes vazadas & $1,79 \%$ & $18,2{ }^{\circ} \mathrm{C}$ \\
Blocos com paredes maciças & $1,84 \%$ & \\
\hline \hline
\end{tabular}
Fonte: Autor (2020).

A Figura 4.3 apresenta a forma de organização e posicionamento dos corpos de prova no interior do forno.

Figura 4.3 - Organização da fornada I

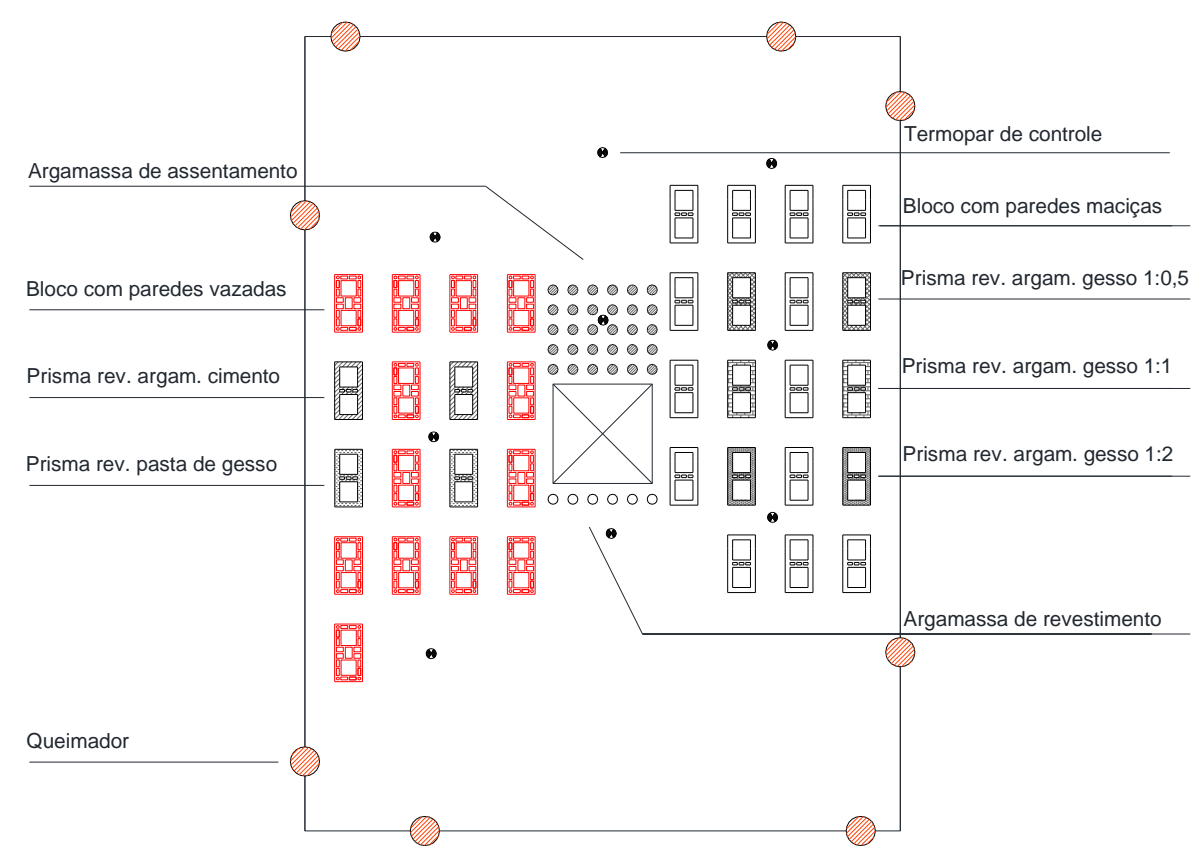

Fonte: Autor (2020).

A Figura 4.4 ilustra a disposição de todos os corpos de prova no interior do forno, em instante anterior a realização do ensaio. Os elementos tiveram suas faces superior e inferior isoladas com uma camada de manta térmica de fibra cerâmica para impedir a passagem de gases para o interior dos blocos, pois na grande maioria das aplicações práticas, esse efeito é provocado pelo posicionamento das lajes de concreto, entre as quais os elementos são inseridos, resultando em uma ação do fogo apenas nas faces laterais. Posteriormente, fragmentos de materiais alternativos foram posicionados sobre a camada isolante de manta 
térmica, de modo a garantir o correto posicionamento e evitar possíveis movimentações da mesma durante o ensaio. Acrescenta-se que a presença de corpos de prova adicionais que por ventura apareceram nas imagens dos ensaios, fez parte de uma série de testes que foram realizados concomitantemente e, portanto, eximem-se do escopo deste trabalho.

Figura 4.4 - Disposição dos corpos de prova na fornada I
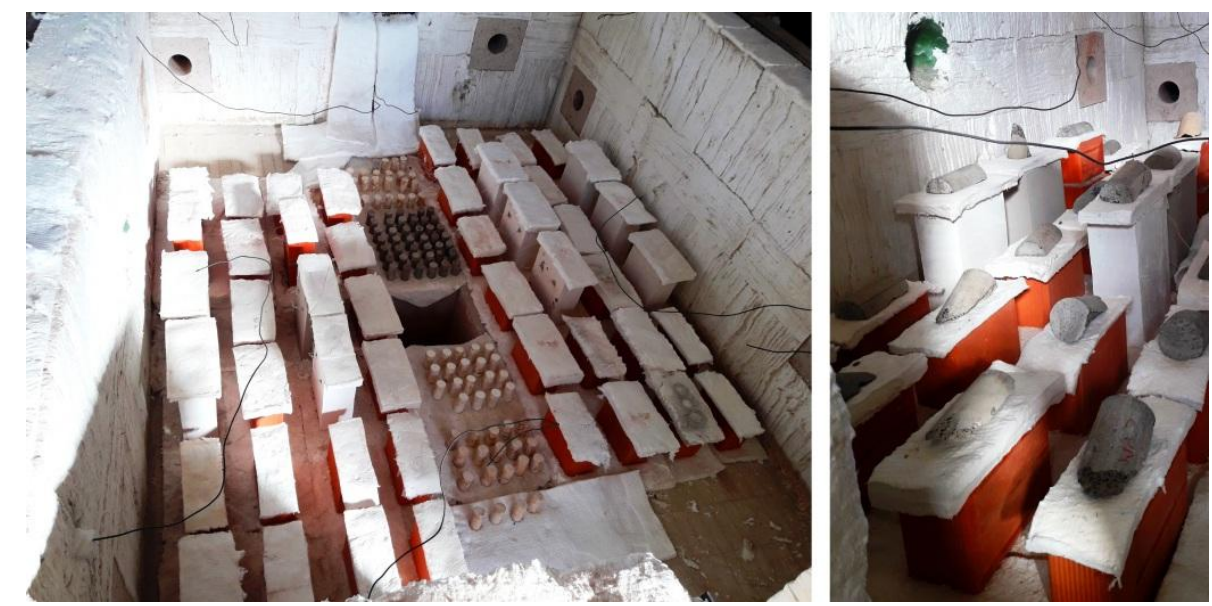

Fonte: Autor (2020).

\subsubsection{Fornada II}

$\mathrm{Na}$ fornada II, prismas e pequenas paredes de alvenaria foram destinados ao forno para verificação dos seus desempenhos quanto à ação do fogo. Particularmente, as pequenas paredes foram avaliadas segundo duas condições distintas, variando-se a atuação do fogo nas faces dos elementos. Pequenas paredes isoladas foram ensaiadas sob as mesmas condições que os demais corpos de prova apresentados anteriormente, com aplicação do fogo em todas as faces laterais do elemento. No entanto, uma série destes elementos foi avaliada em condições nas quais apenas uma das faces laterais esteve sujeita à ação das chamas, para avaliar o grau de compartimentação promovido pelas pequenas paredes, conforme Figura 4.5.

Figura 4.5 - Pequenas paredes compartimentadas ensaiadas em trio
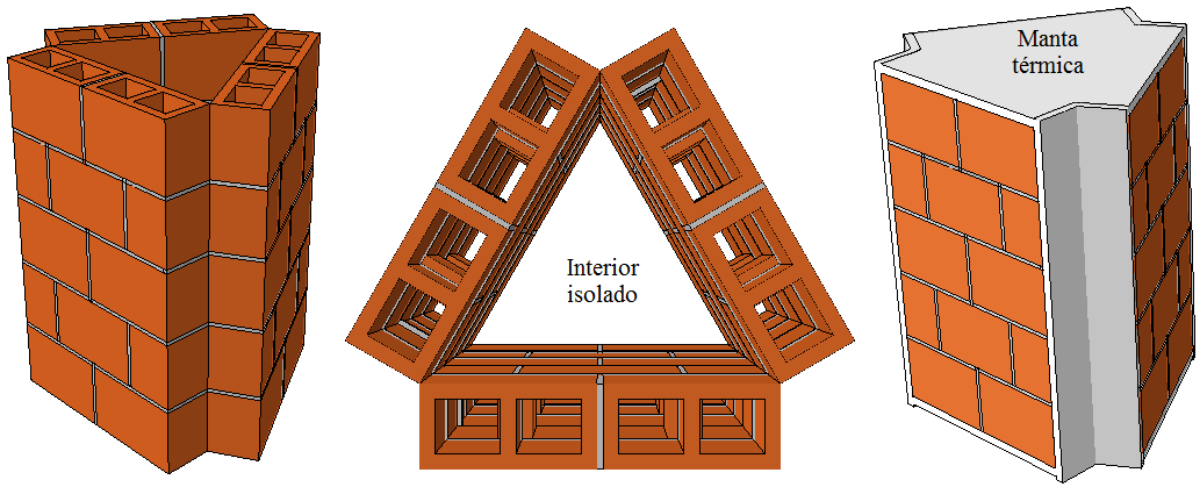

Fonte: Autor (2020). 
Nesta configuração, pequenas paredes compartimentadas foram ensaiadas em trios de modo que o arranjo das mesmas se aproxime em planta de um triângulo equilátero. Para garantir o correto isolamento dos elementos, camadas isolantes de manta térmica foram dispostas nas faces laterais, inferiores e superiores.

Ressalta-se que esta foi uma adaptação para a realização de ensaio que pudesse avaliar o isolamento térmico dos elementos estruturais, e não seguiu o preconizado pelo Eurocode 6 Part 1-2:2005, que recomenda que uma das faces do elemento permaneça em temperatura ambiente, portanto, sem o aprisionamento de gases. Realizou-se essa modificação devido à impossibilidade do ensaio usual em um forno horizontal, como o utilizado neste trabalho. No entanto, essa configuração de ensaio já foi realizada com resultados satisfatórios em trabalhos anteriores como Dupim (2019).

Nesse contexto, a Tabela 4.4 discrimina a quantidade de corpos de prova que foram ensaiados na fornada II, e especifica os prismas e as pequenas paredes em ambas as situações de ensaio.

Tabela 4.4 - Quantidade e especificação dos corpos de prova da fornada II

\begin{tabular}{ccc}
\hline $\begin{array}{c}\text { Tipo de corpo de } \\
\text { prova }\end{array}$ & Especificação & Quantidade \\
\hline \hline \multirow{2}{*}{ Prismas } & Com blocos de paredes vazadas & 6 \\
& Com blocos de paredes maciças & 6 \\
\hline \multirow{3}{*}{ Pequenas paredes } & Isoladas, com blocos de paredes vazadas & 3 \\
& Isoladas, com blocos de paredes maciças & 3 \\
& Compartimentadas, com blocos de paredes vazadas & 3 \\
& Compartimentadas, com blocos de paredes maciças & 3 \\
\hline \hline
\end{tabular}

Fonte: Autor (2020).

De maneira similar, para aferição da umidade relativa do material, os dois tipos de blocos cerâmicos tiveram suas respectivas massas comparadas com a massa seca do material (Tabela 3.6) e apresentadas na Tabela 4.5.

Tabela 4.5 - Temperatura ambiente e umidade relativa dos corpos de prova da fornada II

\begin{tabular}{ccc}
\hline \hline Unidade & Umidade relativa & $\begin{array}{c}\text { Temperatura } \\
\text { ambiente }\end{array}$ \\
\hline Blocos com paredes vazadas & $1,32 \%$ & $24,1^{\circ} \mathrm{C}$ \\
Blocos com paredes maciças & $1,65 \%$ & \\
\hline \hline
\end{tabular}
Fonte: Autor (2020).

A Figura 4.6 ilustra a forma de organização e posicionamento dos corpos de prova no interior do forno, atentando-se à uniformidade na distribuição dos mesmos para evitar regiões de contato direto com as chamas advindas dos queimadores. 
Figura 4.6 - Organização da fornada II

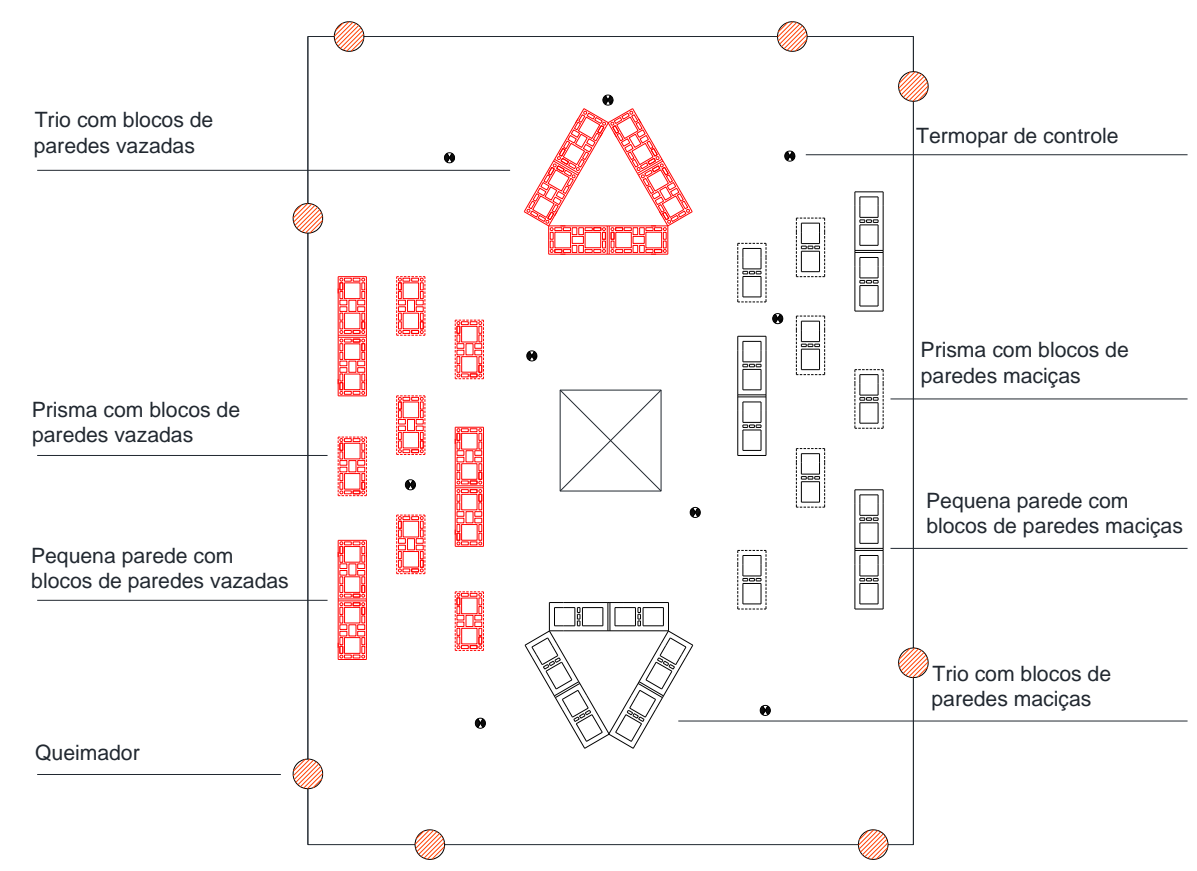

Fonte: Autor (2020).

A disposição dos elementos de alvenaria no interior do equipamento em instante anterior à realização do ensaio pode ser vista na Figura 4.7. Conforme comentado anteriormente, um material isolante foi utilizado nas duas faces transversais para evitar a entrada de gases.

Figura 4.7 - Disposição dos corpos de prova na fornada II

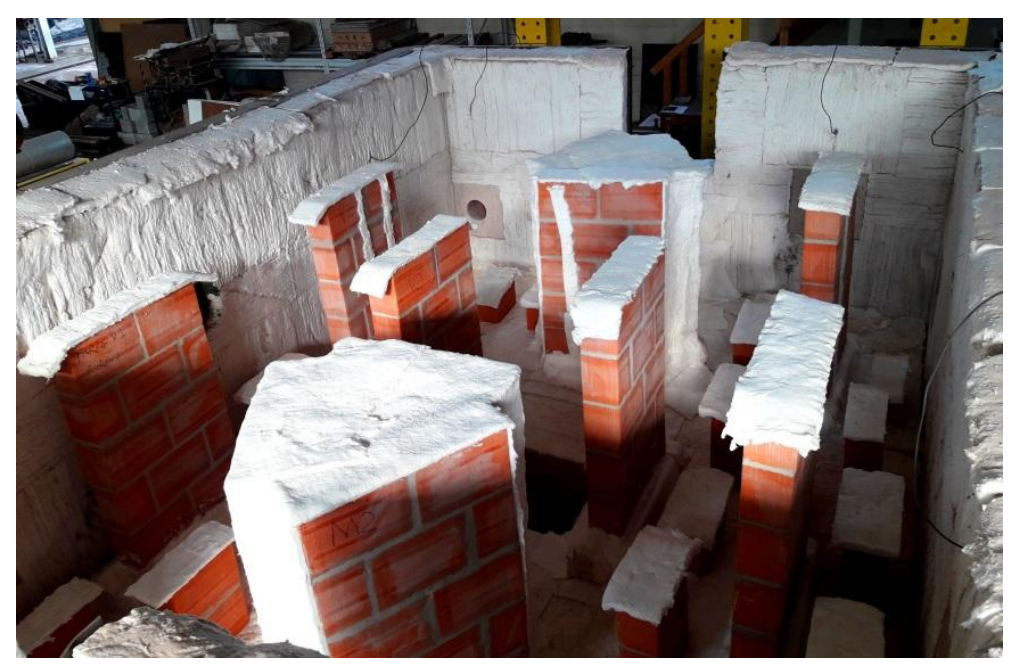

Fonte: Autor (2020).

\subsubsection{Fornada III}

$\mathrm{Na}$ fornada III ensaiaram-se apenas pequenas paredes compartimentadas. Desse modo, de posse do espaço disponível no interior do forno, trios de pequenas paredes foram ensaiados 
em quatro diferentes condições, sendo que as paredes compartimentadas ensaiadas na fornada II tiveram que ser repetidas devido a problemas no sistema de aquisição do referido ensaio, que impossibilitou a captação de dados quanto à elevação de temperatura nos trios de pequenas paredes sem revestimento.

Nessas circunstâncias, como as pequenas paredes com blocos de paredes vazadas apresentaram maior grau de deterioração, apenas estas foram avaliadas quanto à aplicação de revestimentos. Quanto aos revestimentos utilizados, a escolha baseou-se mediante verificação da aderência dos revestimentos aplicados nos prismas ensaiados na fornada I.

Conforme a Figura 4.8, observou-se elevada degradação dos revestimentos, destacando-se que os revestimentos com utilização de gesso apresentaram uma melhoria na aderência conforme aumento do teor de agregados presente na composição. Esta avaliação foi apenas qualitativa, tendo em vista que o alto desgaste dos prismas impossibilitou a realização de ensaios mecânicos para obtenção da resistência à aderência como aqueles apresentados no item 3.3.4.

Figura 4.8 - Prismas cerâmicos revestidos com (a) argamassa de cimento (b) pasta de gesso e argamassas de gesso (c) 1:0,5 (d) 1:1 e (e) 1:2 após situação de incêndio

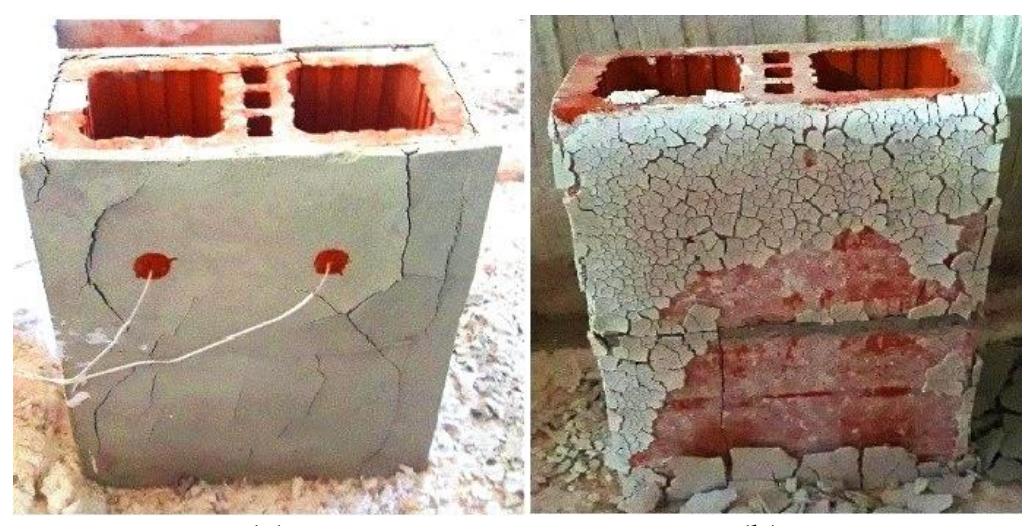

(a)

(b)

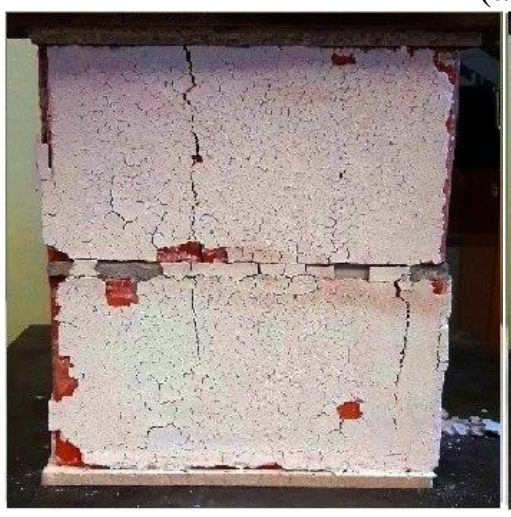

(c)

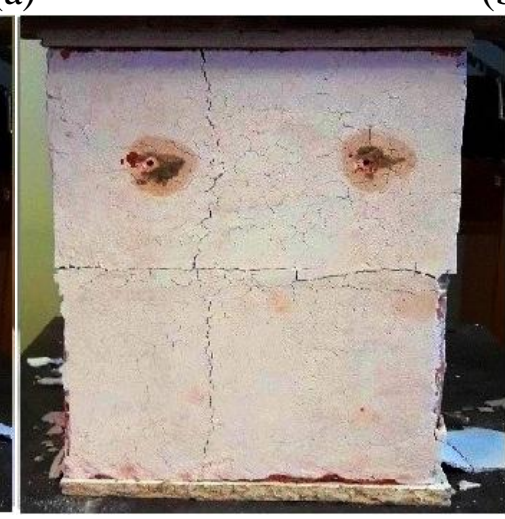

(d)

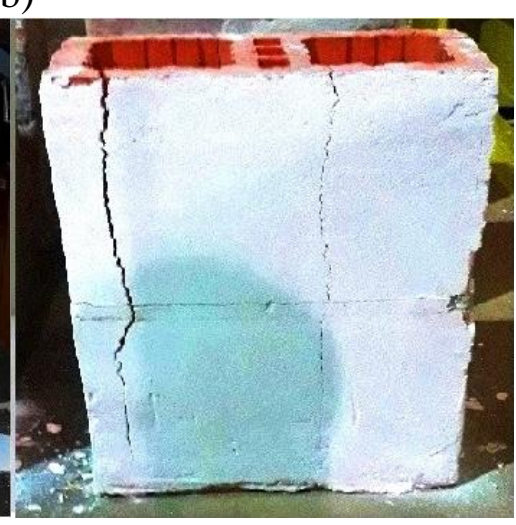

(e)

Fonte: Autor (2020).

Em geral, o gesso possui considerável quantidade de água livre, o que favorece o fenômeno da retração nos revestimentos à base de gesso, devido à rápida expulsão da água 
provocada pela elevação de temperatura, conforme a Figura 4.8 (b). Naturalmente, a substituição do gesso pela areia reduz esse fenômeno devido à menor quantidade de gesso na mistura, e maior aderência promovida pela presença das partículas ásperas dos agregados, que favorecem o incremento da rugosidade superficial do revestimento, que por sua vez aumenta mediante acréscimo do teor de agregados, como ilustrado na Figura 4.8 (c), (d) e (e).

Assim, para avaliar o desempenho de dois diferentes tipos de revestimento, utilizaramse as argamassas de cimento e as argamassas de gesso 1:2 no revestimento das pequenas paredes compartimentadas em situação de incêndio. Devido à necessidade de repetição dos ensaios nas pequenas paredes sem revestimento, o espaço disponível no forno não possibilitou que os elementos com blocos de paredes maciças também fossem avaliados quanto ao revestimento. A Tabela 4.6 detalha e especifica os demais elementos submetidos ao ensaio na fornada III.

Tabela 4.6 - Quantidade e especificação dos corpos de prova da fornada III

\begin{tabular}{ccc}
\hline $\begin{array}{c}\text { Tipo de corpo de } \\
\text { prova }\end{array}$ & Especificação & Quantidade \\
\hline \hline Pequenas paredes & Com blocos de paredes vazadas & 3 \\
compartimentadas & $\begin{array}{c}\text { Com blocos de paredes maciças } \\
\text { argamassa de cimento 1:3, com a/g }=1,50 \\
\text { Com blocos de paredes vazadas revestidas com } \\
\text { argamassa de gesso 1:2, com a/g =0,90 e areia fina }\end{array}$ & 3 \\
\hline \hline
\end{tabular}

Fonte: Autor (2020).

A umidade relativa do material foi verificada conforme procedimento descrito no item 4.3.1, através da relação entre a massa seca e massa verificada no instante do ensaio, e segue ilustrada na Tabela 4.7.

Tabela 4.7 - Temperatura ambiente e umidade relativa dos corpos de prova da fornada III

\begin{tabular}{ccc}
\hline \hline Unidade & Umidade relativa & $\begin{array}{c}\text { Temperatura } \\
\text { ambiente }\end{array}$ \\
\hline \hline Blocos com paredes vazadas & $1,35 \%$ & $22,0^{\circ} \mathrm{C}$ \\
Blocos com paredes maciças & $1,67 \%$ & \\
\hline \hline
\end{tabular}

Fonte: Autor (2020).

Finalmente, a Figura 4.9 apresenta a forma de organização e a distribuição dos corpos de prova, e a Figura 4.10 ilustra o interior do forno após a disposição dos corpos de prova em instante imediatamente anterior à realização do ensaio. 
Figura 4.9 - Organização da fornada III

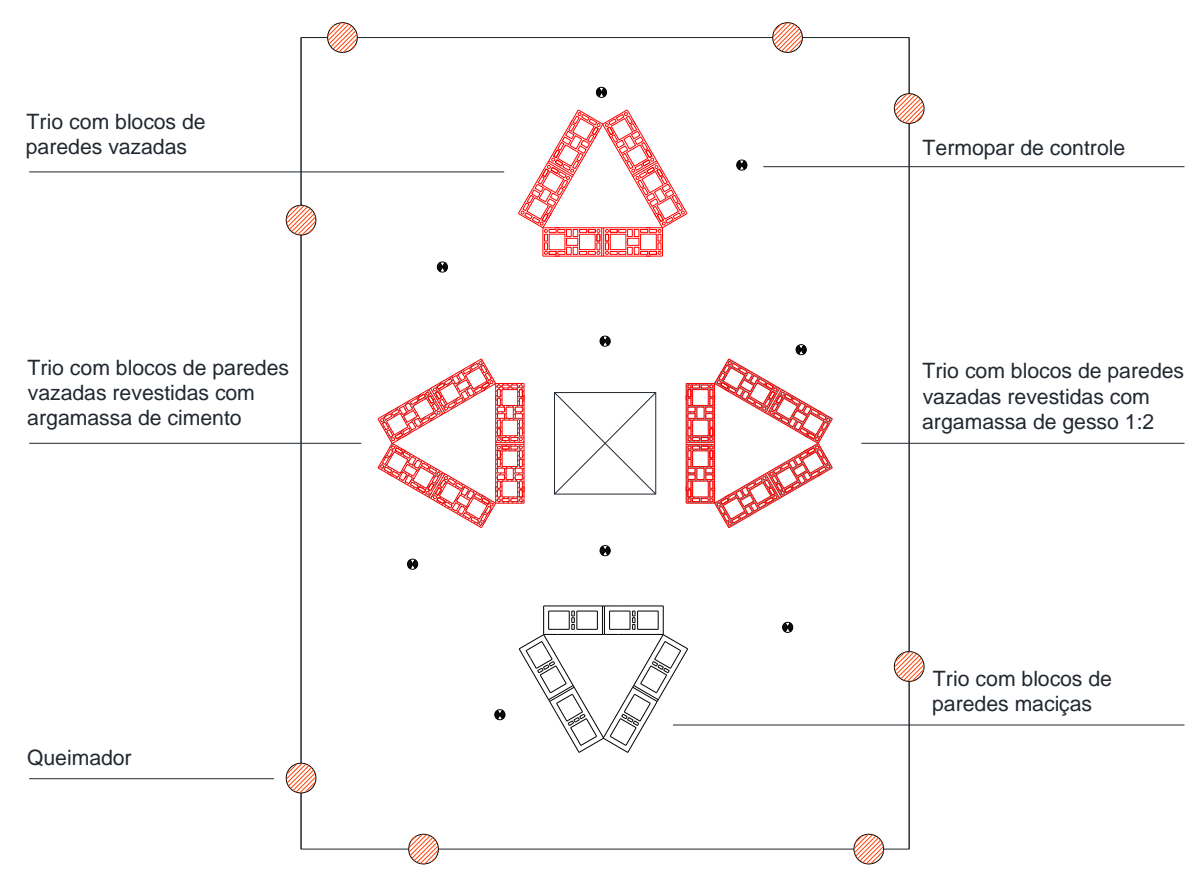

Fonte: Autor (2020).

Figura 4.10 - Disposição dos corpos de prova na fornada III
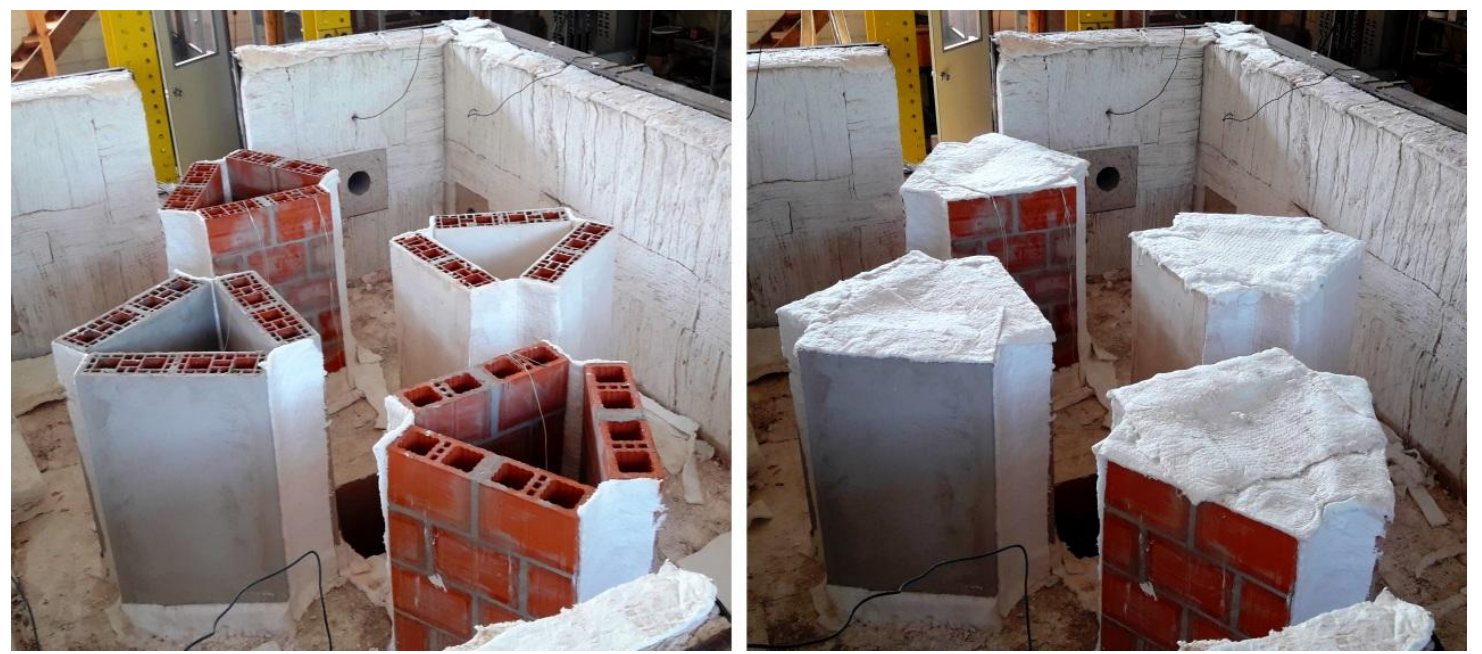

Fonte: Autor (2020).

\subsection{INSTRUMENTAÇÃO}

Para avaliação e acompanhamento da evolução de temperatura nos corpos de prova de alvenaria estrutural, instalaram-se cabos termopares ao longo da seção transversal do elemento, o que possibilitou a obtenção de curvas tempo x temperatura em diferentes pontos. O desenvolvimento da temperatura nos elementos estruturais mostrou-se como uma verificação importante, tendo em vista a variação de parâmetros mecânicos com o aumento de temperatura. Além disso, as medidas possibilitaram o entendimento quanto ao fluxo de calor 
desenvolvido nos elementos, e podem auxiliar na calibração de modelos numéricos com ênfase no seu comportamento térmico.

Para este fim, utilizaram-se cabos termopares do tipo K, isolados com fibra de vidro e temperatura máxima nominal de $700{ }^{\circ} \mathrm{C}$. Tais termopares possuem diâmetro de $2,5 \mathrm{~mm}$, e são compostos por dois cabos individuais, sendo um positivo e outro negativo, constituídos por Chromel e Alumel, respectivamente, que são ligas metálicas com predominância dos elementos Níquel, Cromo e Alumínio.

Para medição da temperatura em pontos específicos dos corpos de prova foi necessário realizar a união e soldagem entre as extremidades dos dois cabos, pois este ponto em comum possibilitou a medição de temperatura. O procedimento de soldagem foi realizado a partir de uma descarga capacitiva, com auxílio do equipamento TAU (Thermocouple Attachment Unit), modelo 41757 da Stork Cooperheat.

Para inserção dos termopares nos corpos de prova, com auxílio de uma furadeira foram realizados pequenos orifícios com $4 \mathrm{~mm}$ de diâmetro em diferentes regiões da seção transversal. A profundidade dos mesmos foi controlada através da haste de profundidade de um paquímetro digital com resolução de $0,01 \mathrm{~mm}$.

O material de preenchimento dos orifícios precisou garantir a fixação dos termopares durante todo o ensaio. Este material também possui influência no processo de medição da evolução de temperatura no corpo de prova, tendo em vista que o contato estabelecido entre os cabos termopares e o elemento estrutural foi realizado através do material de preenchimento, portanto, esperava-se que o comportamento térmico do material não fosse muito diferente daquele do material constituinte da alvenaria, de modo que fossem evitadas distorções nos resultados obtidos.

Diante disso, o material de preenchimento também foi objeto de análise realizada durante a primeira fornada. Para os pontos internos de medidas foram testados uma massa de resina epóxi, pasta de cimento e uma mistura de argilas que constituía o mesmo material utilizado no processo de fabricação do bloco. Devido à rápida deterioração da resina e da pasta de cimento quando submetidos a elevadas temperaturas, adotou-se a mistura de argila para preenchimento e auxílio durante o processo de instrumentação deste trabalho.

A mistura utilizada era composta de dois tipos de argila (preta e amarela), um argilito e carvão mineral. A composição da argila foi gentilmente cedida pela Cerâmica Palma de Ouro, e a mistura foi colhida e armazenada logo após o processo de extrusão do material. O aspecto superficial do mesmo pode ser observado na Figura 4.11. 
Figura 4.11 - Mistura de argila utilizada para auxílio na instrumentação
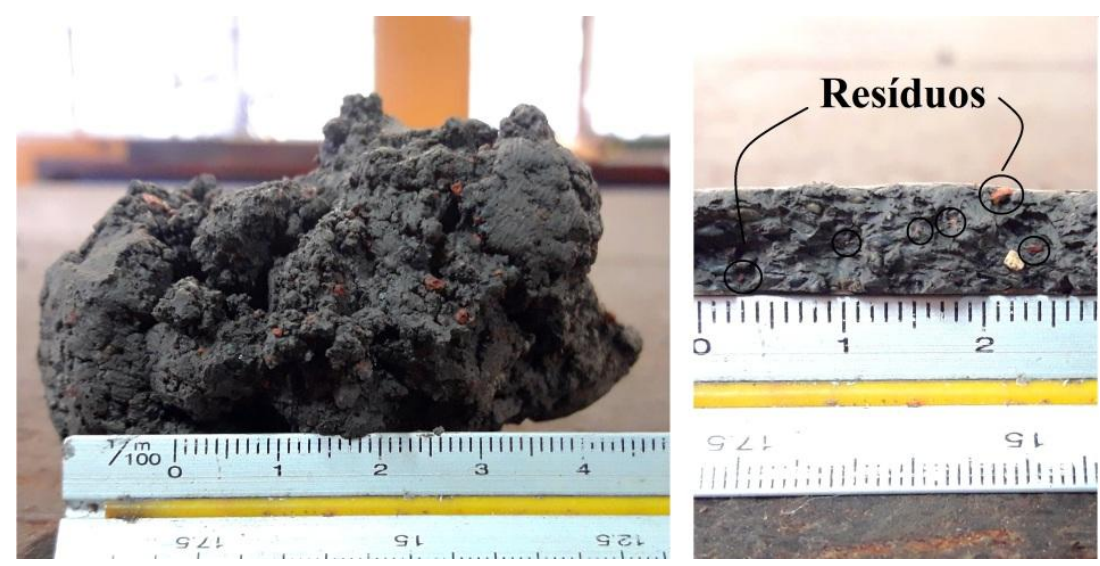

Fonte: Autor (2020).

Em uma análise do material argiloso, observou-se uma quantidade relevante de resíduos cerâmicos presentes na mistura de argila. A adição destes resíduos ao material é comumente realizada na indústria cerâmica visando reduzir o desperdício de material devido ao descarte das unidades cerâmicas rejeitadas após a queima, por inconformidades geométrica, física ou mecânica.

No entanto, destaca-se que a incorporação dos resíduos na mistura pode ser prejudicial ao material cerâmico desenvolvido após a queima da argila, e consequentemente influenciar no desempenho das unidades cerâmicas, devido à formação de microfissuras durante o processo de extrusão do material, provocadas pela presença dos materiais rígidos granulares imergidos na massa pastosa de argila, conforme ilustrado na Figura 4.12 (a).

Figura 4.12 - Microfissura e interface devido à presença dos resíduos cerâmicos

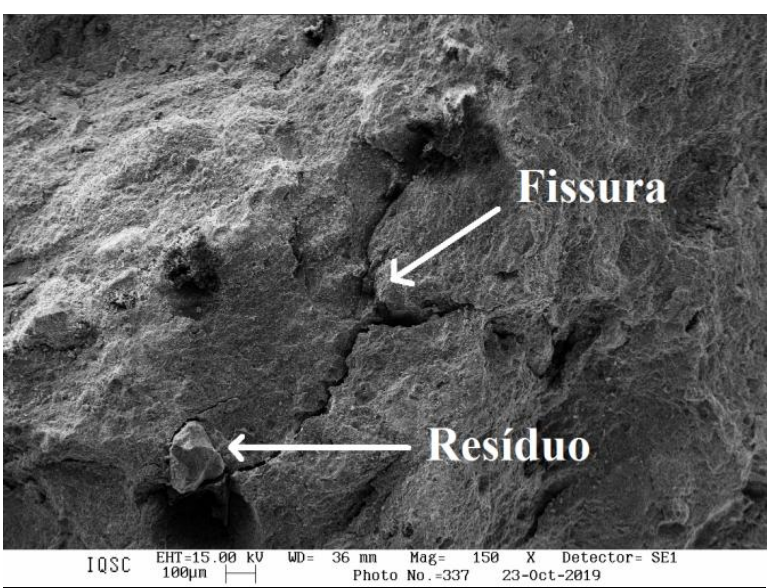

(a)

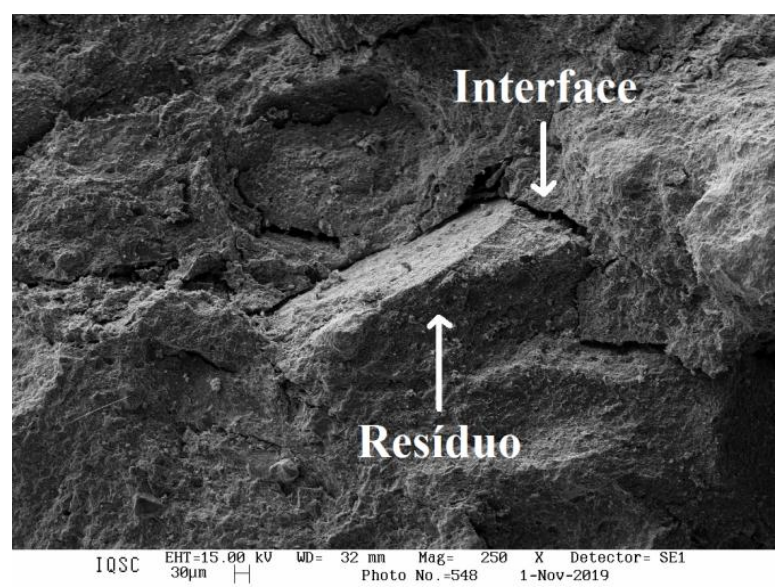

(b)

Fonte: Autor (2020).

Este fato também foi constatado por Villar (2005), que enfatizou que a disposição agrupada das microfissuras pode promover a formação de planos de fraqueza ao longo da direção da extrusão do material, prejudicando assim o seu comportamento mecânico. Além 
disso, conforme apresentado na Figura 4.12 (b), a retração natural sofrida pela argila úmida durante o processo de queima do material, favorece o desgaste da zona de transição entre o resíduo cerâmico e a argila, promovendo o surgimento de uma interface bem definida e o possível desprendimento do resíduo, ocasionando a formação de vazios e, por conseguinte, a concentração de tensões no material, como mostra a Figura 4.13.

Figura 4.13 - Formação de vazio devido ao desprendimento de resíduo cerâmico

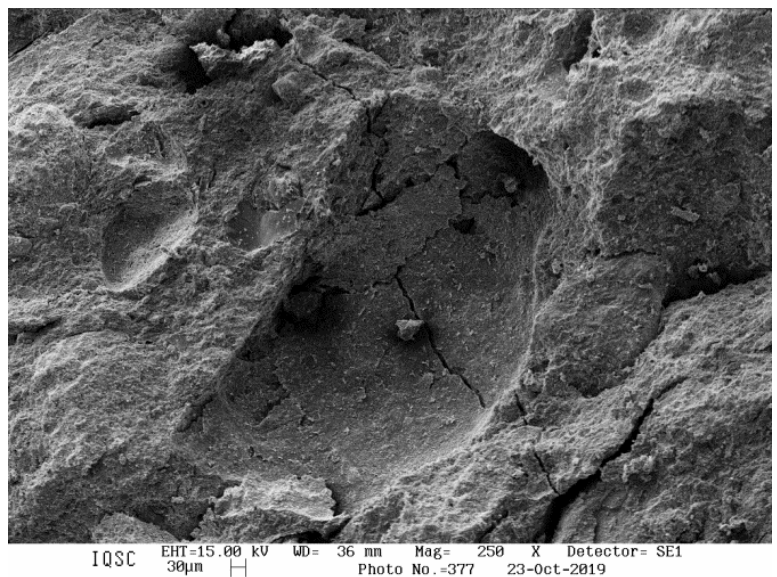

Fonte: Autor (2020).

Quanto à instalação dos termopares nos elementos estruturais, estes foram protegidos com manta cerâmica enquanto presentes no interior do forno, e tiveram a extremidade oposta conectada a dois sistemas de aquisição de dados, sendo um acoplado ao próprio equipamento e outro adicional com modelo System 5000. Para todos os corpos de prova fixaram-se os pontos de medida nos diferentes elementos com o objetivo de obter as isotermas de temperatura na seção transversal. Devido ao custo do material, instrumentou-se apenas um corpo de prova para cada série de elementos. A Figura 4.14 exemplifica a instalação dos cabos termopares nos elementos de alvenaria estrutural.

Figura 4.14 - Disposição dos cabos termopares em elementos de alvenaria
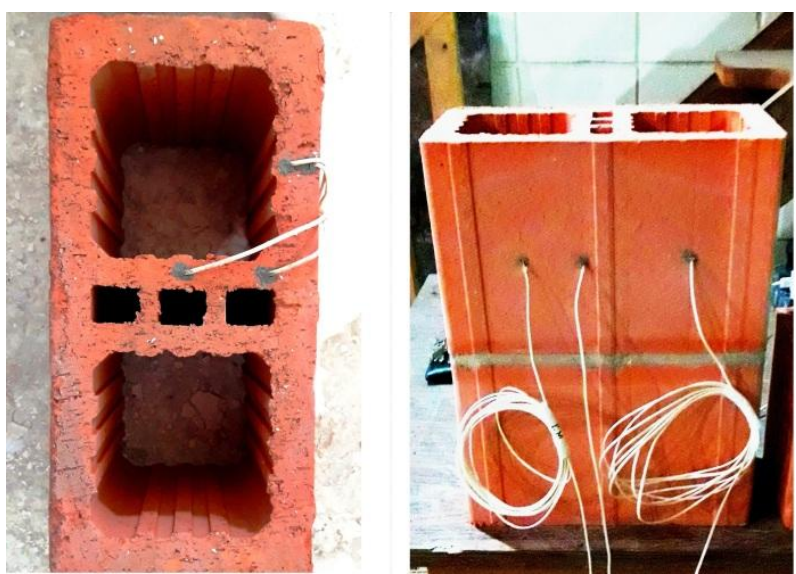

Fonte: Autor (2020) 
Os termopares dos elementos com blocos de paredes vazadas foram identificados com a sigla "TV" e posicionados na seção transversal a distâncias de 10, 25, 48, 70, 115, 130 e 140 $\mathrm{mm}$ da face externa longitudinal de referência (face superior em planta). Para os elementos com blocos de paredes maciças, a instrumentação foi denominada de "TM" e fixada na seção transversal a 5, 15, 28, 70,112, 135 e $140 \mathrm{~mm}$ da face externa longitudinal. A variação entre os pontos de fixação dos termopares entre os dois tipos de unidades ocorreu devido à geometria das mesmas, que exigiu o posicionamento dos cabos em regiões mais regulares como pontos médios e de interseção entre os septos.

A seguir, apresenta-se a disposição dos termopares utilizados para instrumentação dos corpos de prova deste trabalho. A cada figura ilustrada, uma tabela adicional será apresenta especificando o posicionamento dos pontos de instrumentação para cada corpo de prova. Acrescenta-se que as setas de cor preta indicam as faces nas quais o elemento esteve sujeito à ação do fogo. As Figuras 4.15, 4.16 e 4.17, mostram a instrumentação dos blocos, prismas e pequenas paredes isoladas, respectivamente.

Figura 4.15 - Instrumentação dos blocos com paredes (a) vazadas e (b) maciças

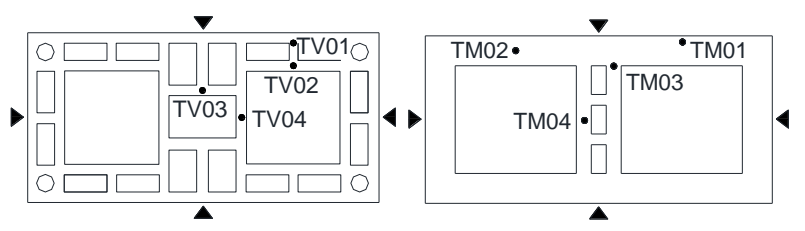

(a)

(b)

Fonte: Autor (2020).

Tabela 4.8 - Especificação da instrumentação dos blocos

\begin{tabular}{cc|cc}
\hline \hline \multicolumn{2}{c|}{ Unidades com paredes vazadas } & \multicolumn{2}{c}{ Unidades com paredes maciças } \\
\hline \hline Termopar & Distância da face referência & Termopar & Distância da face referência \\
\hline \hline TV01 & $10 \mathrm{~mm}$ & TM01 & $5 \mathrm{~mm}$ \\
TV02 & $25 \mathrm{~mm}$ & TM02 & $15 \mathrm{~mm}$ \\
TV03 & $40 \mathrm{~mm}$ & TM03 & $28 \mathrm{~mm}$ \\
TV04 & $70 \mathrm{~mm}$ & TM04 & $70 \mathrm{~mm}$ \\
\hline \hline
\end{tabular}

Fonte: Autor (2020).

Figura 4.16 - Instrumentação dos prismas com blocos de paredes (a) vazadas e (b) maciças

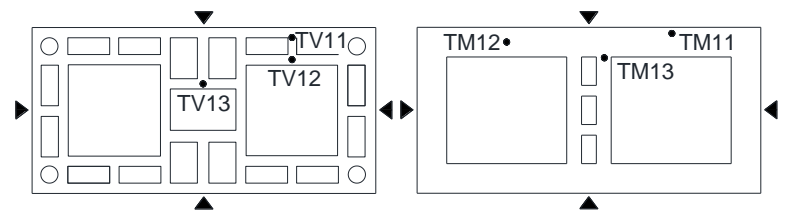

(a)

(b)

Fonte: Autor (2020). 
Tabela 4.9 - Especificação da instrumentação dos prismas

\begin{tabular}{cc|cc}
\hline \hline \multicolumn{2}{c|}{ Unidades com paredes vazadas } & \multicolumn{2}{c}{ Unidades com paredes maciças } \\
\hline \hline Termopar & Distância da face referência & Termopar & Distância da face referência \\
\hline \hline TV11 & $10 \mathrm{~mm}$ & TM11 & $5 \mathrm{~mm}$ \\
TV12 & $25 \mathrm{~mm}$ & TM12 & $15 \mathrm{~mm}$ \\
TV13 & $40 \mathrm{~mm}$ & TM13 & $28 \mathrm{~mm}$ \\
\hline \hline
\end{tabular}

Fonte: Autor (2020).

Figura 4.17 - Instrumentação das pequenas paredes isoladas com blocos de paredes (a) vazadas e (b) maciças

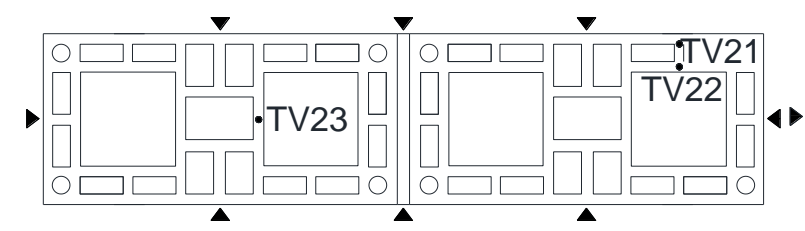

(a)

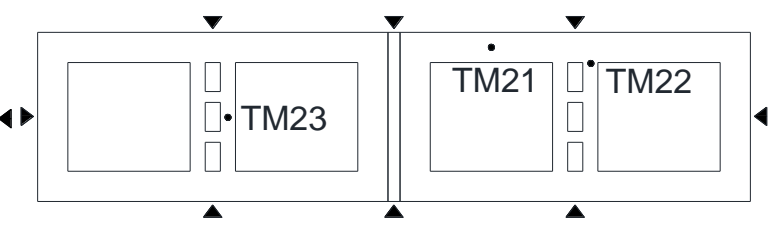

(b)

Fonte: Autor (2020).

Tabela 4.10 - Especificação da instrumentação das pequenas paredes isoladas

\begin{tabular}{cc|cc}
\hline \hline \multicolumn{2}{c|}{ Unidades com paredes vazadas } & \multicolumn{2}{c}{ Unidades com paredes maciças } \\
\hline \hline Termopar & Distância da face referência & Termopar & Distância da face referência \\
\hline TV21 & $10 \mathrm{~mm}$ & TM21 & $15 \mathrm{~mm}$ \\
TV22 & $25 \mathrm{~mm}$ & TM22 & $28 \mathrm{~mm}$ \\
TV23 & $70 \mathrm{~mm}$ & TM23 & $70 \mathrm{~mm}$ \\
\hline \hline
\end{tabular}

Fonte: Autor (2020).

Conforme comentado anteriormente, as pequenas paredes compartimentadas foram ensaiadas através de um arranjo em trios para que fosse possível analisar a compartimentação promovida pelo elemento estrutural. Dessa maneira, um ponto de instrumentação foi posicionado no interior de cada trio para que a temperatura interna pudesse ser verificada e utilizada para avaliação do isolamento térmico. As Figuras 4.18 e 4.19 mostram a instrumentação das pequenas paredes compartimentadas.

Figura 4.18 - Instrumentação das pequenas paredes compartimentadas sem revestimento com blocos de paredes (a) vazadas e (b) maciças

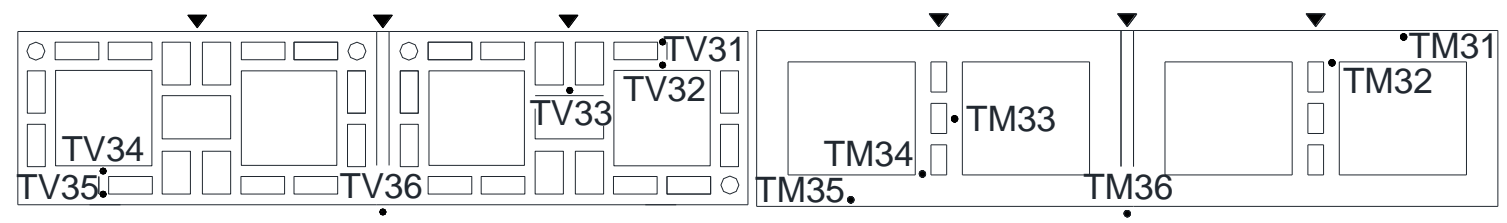

(a)

(b)

Fonte: Autor (2020). 
Tabela 4.11 - Especificação e instrumentação das pequenas paredes compartimentadas sem revestimento

\begin{tabular}{cc|cc}
\hline \hline \multicolumn{2}{c|}{ Unidades com paredes vazadas } & \multicolumn{2}{c}{ Unidades com paredes maciças } \\
\hline \hline Termopar & Distância da face referência & Termopar & Distância da face referência \\
\hline \hline TV31 & $10 \mathrm{~mm}$ & TM31 & $5 \mathrm{~mm}$ \\
TV32 & $25 \mathrm{~mm}$ & TM32 & $28 \mathrm{~mm}$ \\
TV33 & $48 \mathrm{~mm}$ & TM33 & $70 \mathrm{~mm}$ \\
TV34 & $115 \mathrm{~mm}$ & TM34 & $112 \mathrm{~mm}$ \\
TV35 & $130 \mathrm{~mm}$ & TM35 & $135 \mathrm{~mm}$ \\
TV36 & $140 \mathrm{~mm}$ & TM36 & $140 \mathrm{~mm}$ \\
\hline \hline
\end{tabular}

Fonte: Autor (2020).

Figura 4.19 - Instrumentação das pequenas paredes compartimentadas com blocos de paredes vazadas revestidas com argamassa de (a) cimento e (b) gesso 1:2

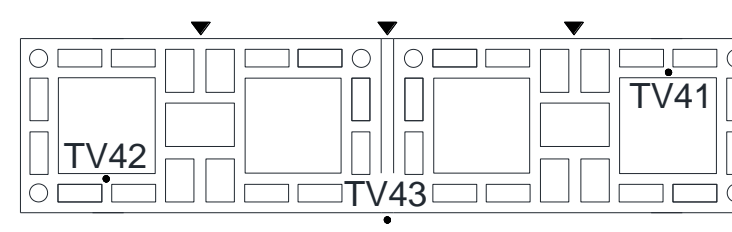

(a)

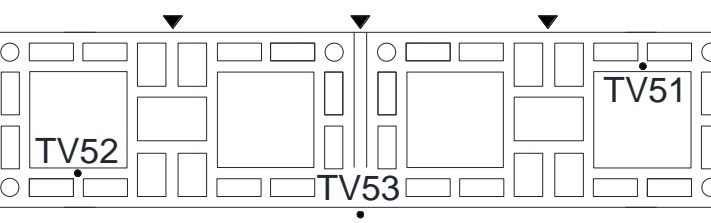

(b)

Fonte: Autor (2020).

Tabela 4.12 - Especificação e instrumentação das pequenas paredes compartimentadas revestidas

\begin{tabular}{cc|cc}
\hline \hline \multicolumn{2}{c|}{ Revestidas com argamassa de cimento } & \multicolumn{2}{c}{ Revestidas com argamassa de gesso 1:2 } \\
\hline \hline Termopar & Distância da face referência & Termopar & Distância da face referência \\
\hline \hline TV41 & $10 \mathrm{~mm}$ & TV51 & $5 \mathrm{~mm}$ \\
TV42 & $130 \mathrm{~mm}$ & TV52 & $130 \mathrm{~mm}$ \\
TV43 & $140 \mathrm{~mm}$ & TV53 & $140 \mathrm{~mm}$ \\
\hline \hline
\end{tabular}

Fonte: Autor (2020).

Duas composições dos revestimentos em gesso também foram avaliadas com o intuito de verificar o campo térmico em duas regiões da seção transversal, conforme a Figura 4.20.

Figura 4.20 - Instrumentação dos revestimentos em gesso (a) pasta e (b) argamassa 1:2

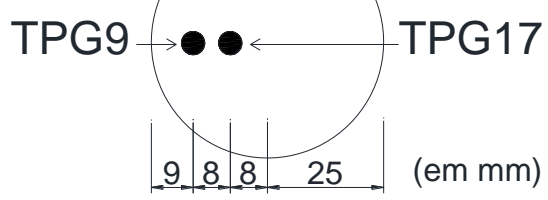

(a)

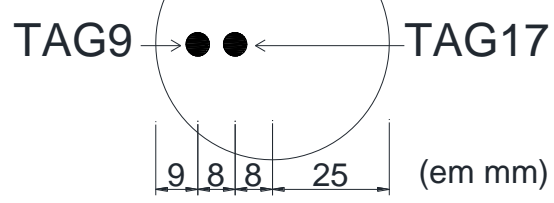

(b)

Fonte: Autor (2020). 
Tabela 4.13 - Especificação e instrumentação dos revestimentos em gesso

\begin{tabular}{cc|cc}
\hline \multicolumn{2}{c|}{ Pasta de gesso, com a/g= 0,45 } & \multicolumn{2}{c}{$\begin{array}{c}\text { Argamassa de gesso 1:2, com a/g= 0,70 e } \\
\text { areia fina }\end{array}$} \\
\hline \hline Termopar & Distância da face referência & Termopar & Distância da face referência \\
\hline \hline TPG9 & $9 \mathrm{~mm}$ & TAG9 & $9 \mathrm{~mm}$ \\
TPG17 & $17 \mathrm{~mm}$ & TAG17 & $17 \mathrm{~mm}$ \\
\hline \hline
\end{tabular}

Fonte: Autor (2020).

\subsection{COMPORTAMENTO TÉRMICO}

Conforme observado anteriormente, a análise do comportamento térmico de elementos estruturais em situação de incêndio foi realizada através da obtenção das curvas tempo $\mathrm{x}$ temperatura adquiridas mediante instrumentação em diferentes pontos dos corpos de prova, possibilitando uma avaliação consistente quanto à evolução de temperatura e o fluxo de calor dos elementos observados.

Os corpos de prova foram submetidos à elevação de temperatura seguindo a curva de incêndio-padrão proposta pela ISO 834-1:1999, apresentada no item 2.3.2.3. Os mesmos estiveram sujeitos à elevação de temperatura em suas faces laterais durante 120 minutos, sendo este o máximo tempo requerido de resistência ao fogo (TRRF) indicado pela ABNT NBR 14432:2001 para edificações residenciais com altura superior a 30 metros, equivalente a prédios usuais de alvenaria estrutural com aproximadamente 10 pavimentos. Além disso, o Corpo de Bombeiros do Estado de São Paulo também recomenda este TRRF através da Instrução técnica IT 08:2018, para edificações residenciais com alturas inferiores a 120 metros.

Durante os ensaios para simulação de incêndio-padrão, a elevação da temperatura interna do forno atendeu satisfatoriamente a curva de incêndio-padrão proposta pela ISO 8341:1999, e manteve-se comportada entre os intervalos de temperatura mínima e máxima recomendados pela ABNT NBR 10636:1989, Paredes divisórias sem função estrutural Determinação da resistência ao fogo, conforme ilustrado na Figura 4.21.

No decorrer da primeira fornada, um dos queimadores do equipamento apresentou problemas, e por este motivo a curva de temperatura média do forno durante a fornada I apresentou-se instável nos primeiros minutos de ensaio, em destaque na Figura 4.21. Entretanto, com a desativação deste queimador, os demais foram capazes de alimentar o processo de queima, possibilitando uma curva média adequada, diante da curva de incêndiopadrão. 
Figura 4.21 - Evolução da temperatura média do forno durante as fornadas

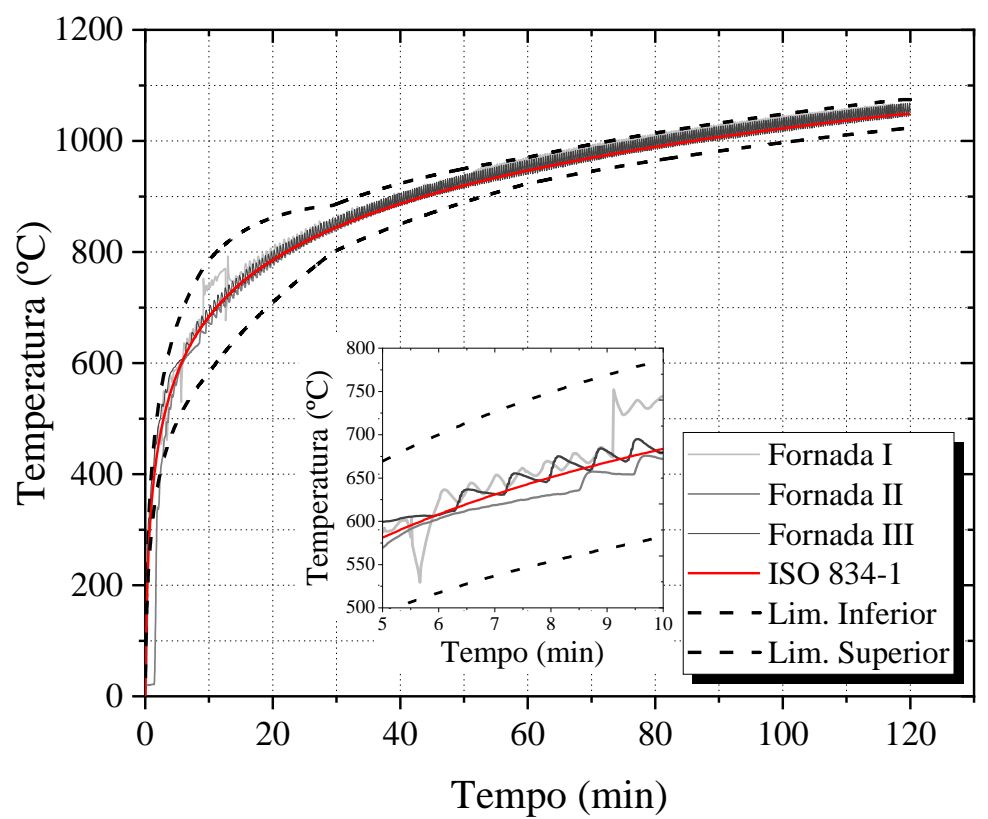

Fonte: Autor (2020).

A seguir, apresentam-se as curvas de elevação de temperatura para os diferentes elementos de alvenaria analisados neste trabalho. As unidades cerâmicas foram avaliadas na fornada I, tiveram sua temperatura acompanha através de quatro pontos ao longo da seção transversal e apresentaram comportamento térmico semelhante ao longo do ensaio. Destacando-se que os blocos com paredes vazadas pronunciaram uma maior elevação de temperatura com menor tempo, sendo possível observar que a partir dos 100 minutos de ensaio, apresentavam uma temperatura aproximadamente uniforme em toda a seção transversal, como pode ser visto na Figura 4.22 (a).

Figura 4.22 - Elevação de temperatura nos blocos com paredes (a) vazadas e (b) maciças

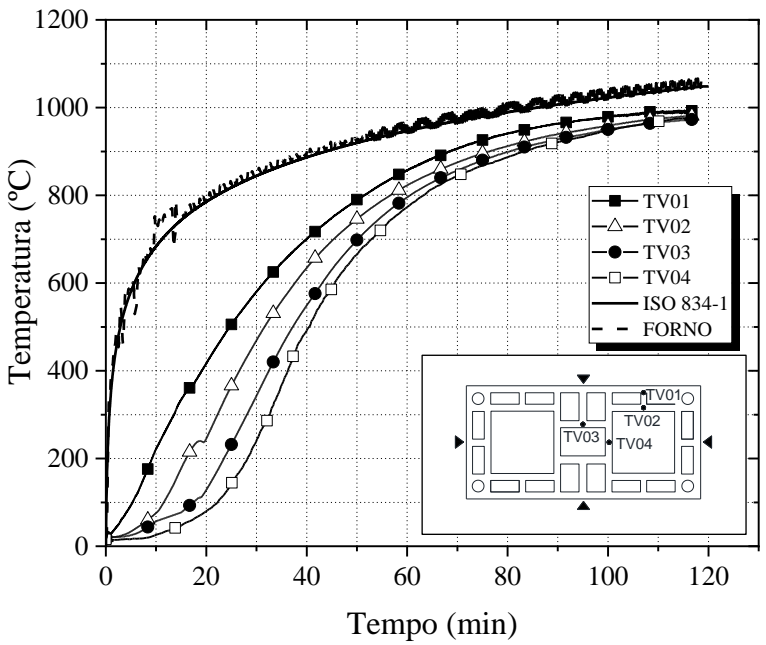

(a)

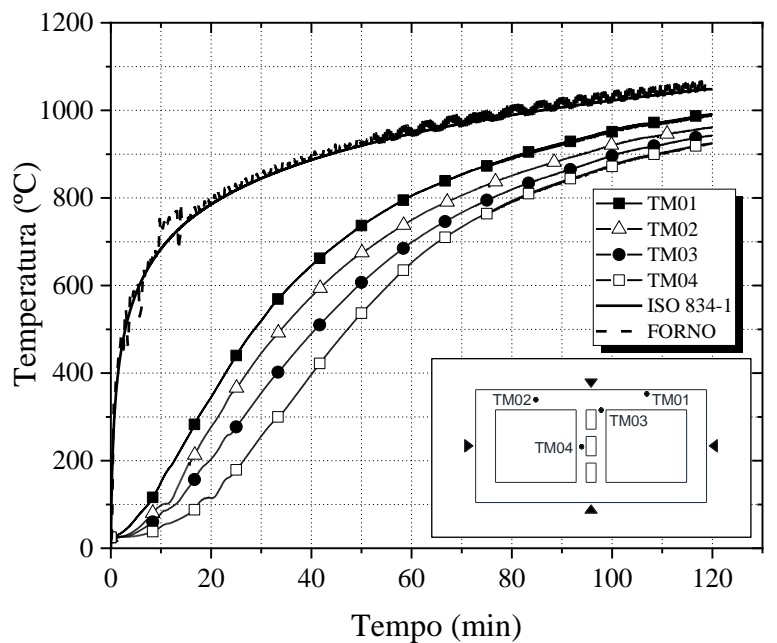

(b)

Fonte: Autor (2020). 
Além disso, realizando-se uma comparação entre a taxa de elevação de temperatura (TV04 e TM04), observou-se que os pontos ao longo dos blocos com paredes vazadas necessitaram de 40 minutos para atingirem a temperatura média de $500{ }^{\circ} \mathrm{C}$, enquanto que nos blocos com paredes maciças esse tempo foi aproximadamente $17 \%$ superior.

Na Figura 4.23 apresentam-se as curvas de acréscimo de temperatura para os prismas cerâmicos com blocos de paredes vazadas e maciças, respectivamente. Estes elementos possuíram três pontos de instrumentação ao longo da seção transversal, e de acordo com o esperado, manifestaram um desenvolvimento da temperatura muito semelhante ao apresentado pelos blocos na Figura 4.22.

Figura 4.23 - Elevação de temperatura nos prismas de alvenaria com blocos de paredes (a) vazadas e (b) maciças

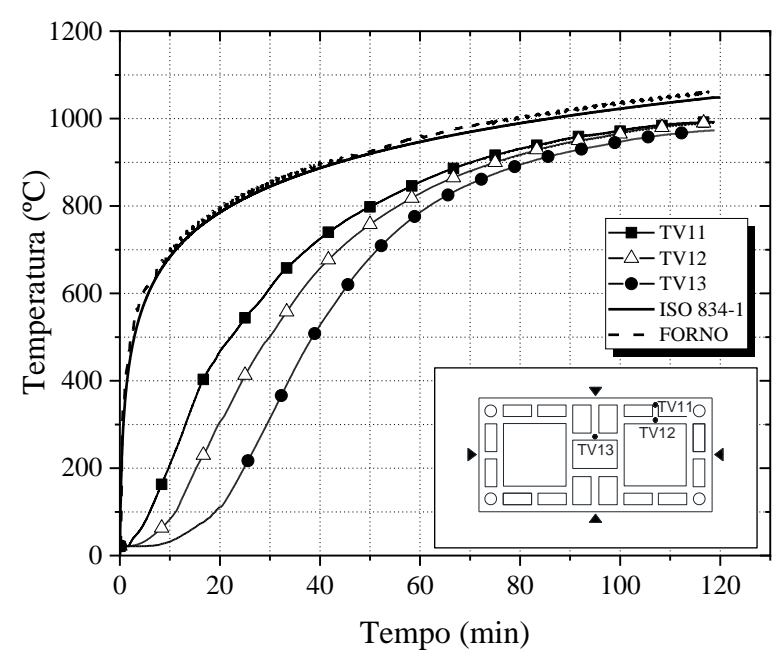

(a)

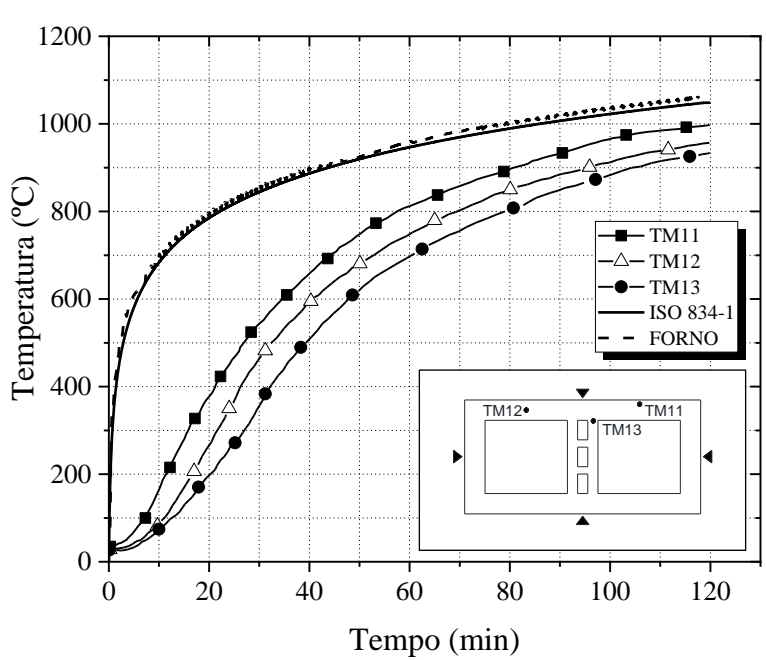

(b)

Fonte: Autor (2020).

Devido às pequenas dimensões de ambos os blocos e prismas, a área de atuação do calor é reduzida nestes elementos, proporcionando um comportamento térmico e evolução de temperatura ao longo da seção transversal muito semelhante entre si. Dessa maneira, dispondo de elementos de mesma seção transversal, sendo este o caso dos blocos e prismas, recomendase a instrumentação e obtenção do campo térmico apenas nas unidades, tendo em vista o menor custo de trabalho com corpos de prova de menores dimensões.

Por outro lado, conforme ilustra a Figura 4.24, notou-se que as pequenas paredes isoladas de alvenaria estrutural, em geral, considerando-se os mesmos pontos de instrumentação e tempo de análise, apresentaram temperaturas superiores em relação aos blocos e prismas. Confrontando-se os resultados para os termopares TM13 e TM23, instalados no mesmo ponto nos prismas e pequenas paredes isoladas com blocos de paredes maciças, respectivamente, observa-se que o ponto TM23 situado na pequena parede alcança a 
temperatura média de $500{ }^{\circ} \mathrm{C}$ aos 30 minutos, cerca de 10 minutos $(25 \%)$ antes do instante em que o prisma atinge a mesma temperatura.

Figura 4.24 - Elevação de temperatura nas pequenas paredes isoladas com blocos de paredes (a) vazadas e (b) maciças

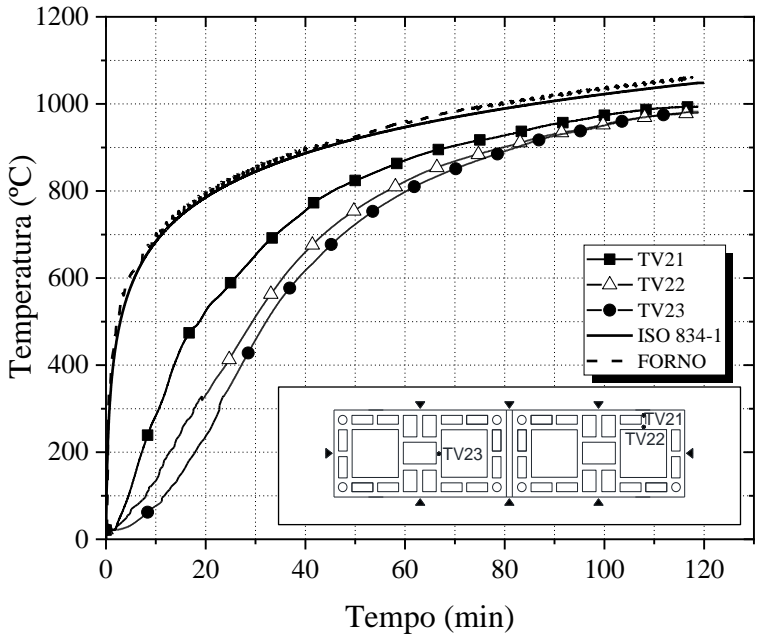

(a)

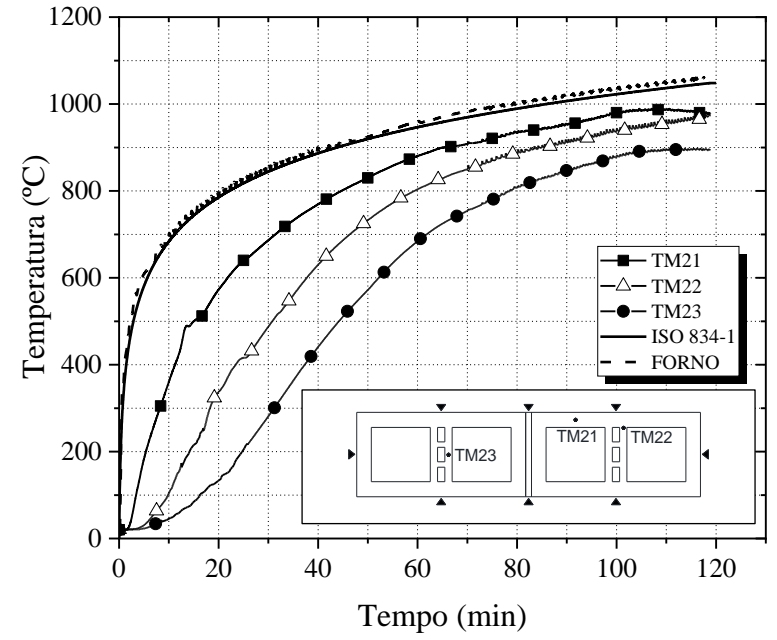

(b)

Fonte: Autor (2020).

Acredita-se que este fato possui relação com as medidas geométricas dos elementos estruturais, tendo em vista que as pequenas paredes possuem dimensões e número de juntas superiores às dos blocos e prismas, e assim sujeitaram-se a maior ação de chamas e calor, promovendo uma variação de temperatura superior em suas seções transversais.

Para as pequenas paredes compartimentadas, devido à atuação do fogo em apenas uma das faces e consequente assimetria do elemento quanto a esta condição, cada corpo de prova foi instrumentado com seis termopares ao longo da seção transversal, conforme a Figura 4.25.

Figura 4.25 - Elevação de temperatura nas pequenas paredes compartimentadas sem revestimento com blocos de paredes (a) vazadas e (b) maciças

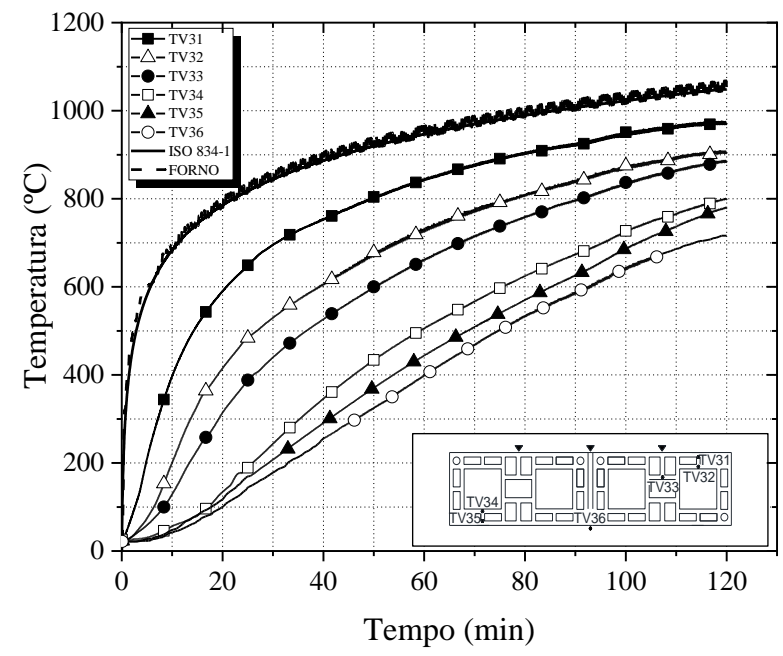

(a)

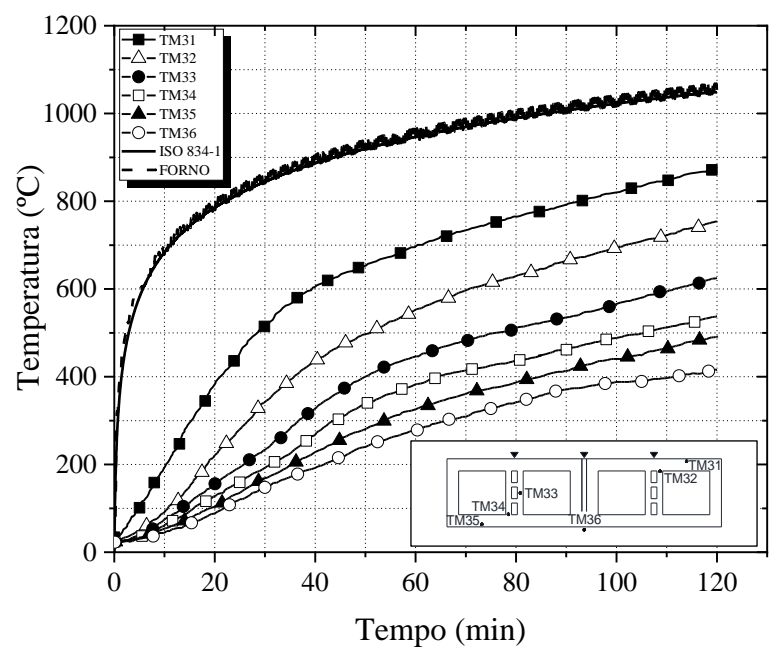

(b)

Fonte: Autor (2020). 
Mediante as curvas de elevação de temperatura em ambos os corpos de prova, observou-se uma grande diferença em relação aos elementos isolados, quanto às temperaturas das faces opostas de cada elemento, que alcançaram uma variação de aproximadamente $260{ }^{\circ} \mathrm{C}$ e $470{ }^{\circ} \mathrm{C}$ para as pequenas paredes com blocos de paredes vazadas e maciças, respectivamente.

Além do mais, pelo espectro de elevação de temperatura ao longo da seção transversal de ambos os tipos de pequenas paredes, constatou-se um maior grau de compartimentação promovido pelos elementos com blocos de paredes maciças, que pôde ser traduzido através da temperatura final entre os termopares situados no interior dos trios (TV36 e TM36) que sofreram aumento de $716^{\circ} \mathrm{C}$ e $415^{\circ} \mathrm{C}$, com uma redução de $42 \%$ neste ponto.

Devido à disponibilidade de pontos no sistema de aquisição de dados, as pequenas paredes compartimentadas e revestidas dispuseram apenas de três pontos de instrumentação na seção transversal. Porém, estes foram suficientes para identificação da eficiência de ambos os revestimentos na compartimentação dos elementos de alvenaria, como pode ser visto na Figura 4.26.

Figura 4.26 - Elevação de temperatura nas pequenas paredes compartimentadas com blocos de paredes vazadas revestidas com argamassa de (a) cimento e (b) gesso 1:2

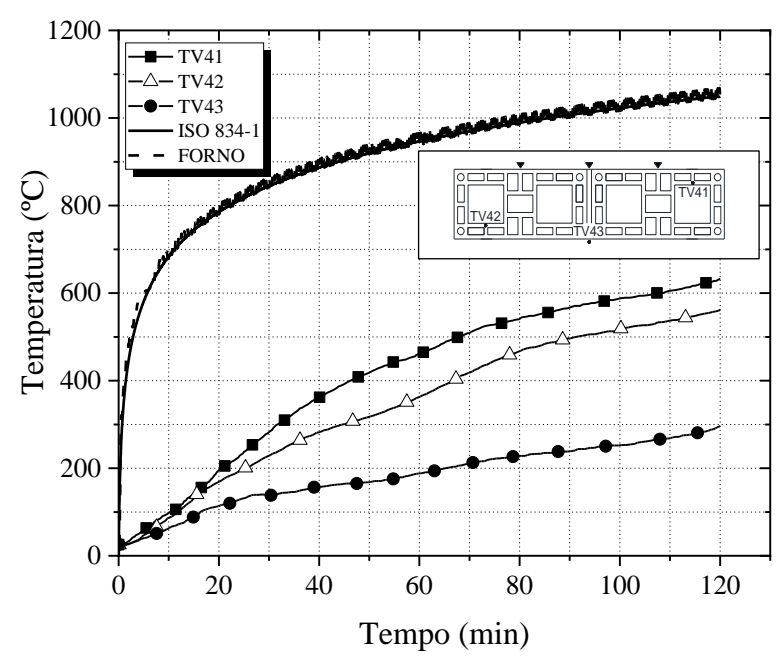

(a)

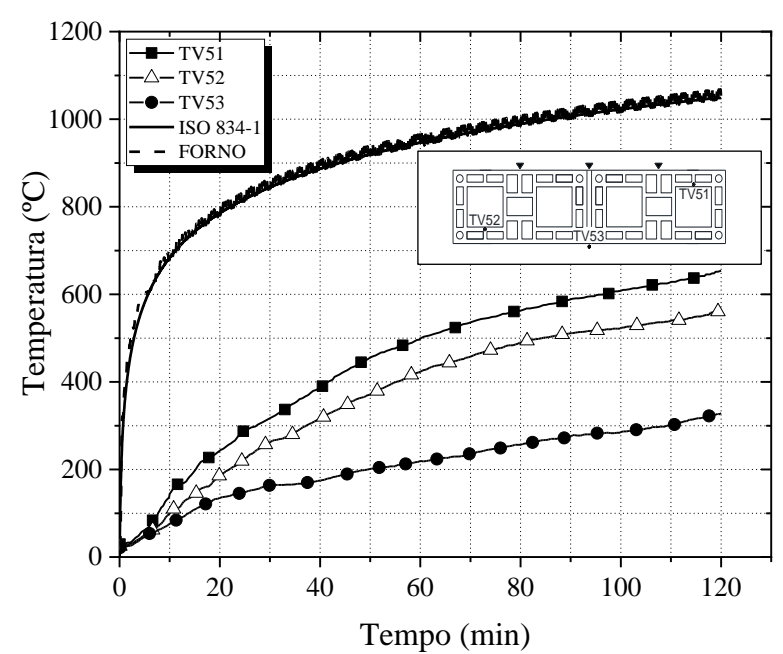

(b)

Fonte: Autor (2020).

Com relação à eficiência dos revestimentos, observou-se que os três pontos de instrumentação coincidentes entre as pequenas paredes com e sem revestimento, apresentaram em média uma redução de $28,9 \%, 29,7 \%$ e 56,4\%, respectivamente, em relação aos pontos TV32, TV34 e TV36 situados a $25 \mathrm{~mm}$ de ambas as faces e no centro dos trios com blocos de paredes vazadas sem revestimento, considerando-se a temperatura final após 120 minutos de ensaio. 
No mesmo contexto, as pequenas paredes revestidas com argamassa de cimento apresentaram temperaturas ligeiramente inferiores a aquelas revestidas com argamassa de gesso. Após 120 minutos de ensaio, para os três pontos avaliados, essa redução foi de 3,2\%, 0,0\% e 9,7\% para TV41, TV42 e TV43, em relação a TV51, TV52 e TV53, respectivamente.

A maior eficiência térmica dos revestimentos em argamassa de cimento em relação às argamassas de gesso pode ser justificada devido à maior porosidade das argamassas de gesso, provocada pela inserção de partículas de maior granulometria como a areia na pasta de gesso, favorecendo um menor adensamento, maior porosidade na zona de transição entre o agregado e a pasta (Figura 4.27 (b)), e consequente maior facilidade para passagem de calor.

Além disso, a formação dos materiais cimentícios se dá em grande parte pelos silicatos de cálcio hidratados (C-S-H) que possuem formas de cristais pequenos e fibrilares, segundo Mehta e Monteiro (2014). Enquanto que Barbosa et al. (2014) descreve que no gesso ocorre a formação de cristais grandes de sulfatos de cálcio dihidratados que possuem a forma de agulhas prismáticas, favorecendo a composição de uma estrutura mais porosa, como ilustra a Figura 4.27.

Figura 4.27 - Micrografias dos revestimentos em argamassas de (a) cimento e (b) gesso 1:2

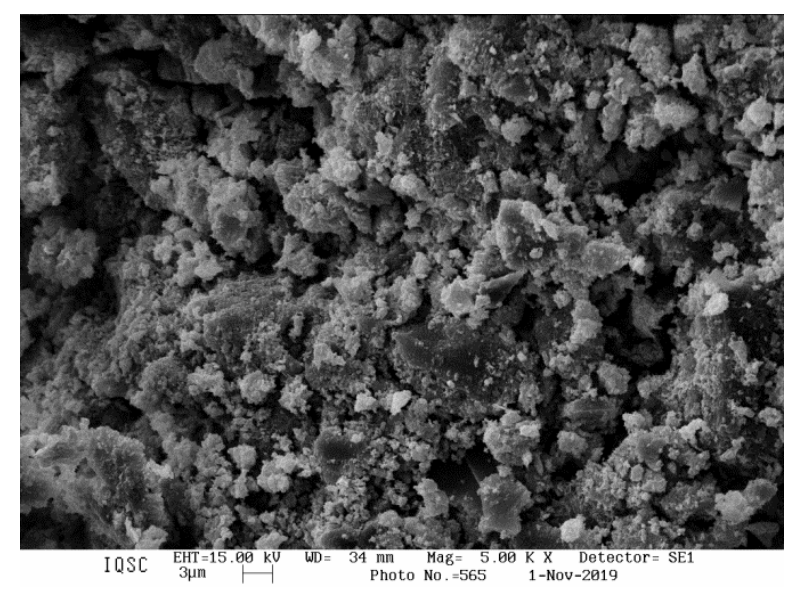

(a)

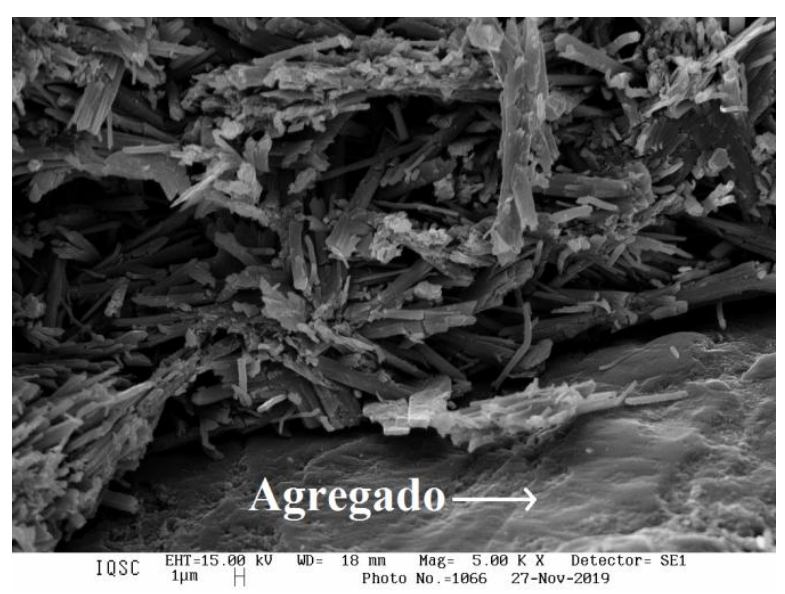

(b)

Fonte: Autor (2020).

De maneira geral, quanto à instrumentação realizada nas unidades e elementos de alvenaria estrutural, observaram-se resultados consistentes com o posicionamento dos cabos termopares, considerando-se que houve uma correta transferência de calor a partir dos resultados obtidos em que a elevação de temperatura foi superior quanto maior à proximidade da superfície de exposição ao fogo.

Quanto à análise da elevação de temperatura nos revestimentos em gesso, para verificação da influência do teor de agregados na transferência de calor do material, as curvas de elevação de temperatura apresentaram grande instabilidade devido às pequenas dimensões 
dos corpos de prova, que favoreceram a elevação de temperatura rapidamente em toda a seção transversal do corpo de prova cilíndrico 50 x $100 \mathrm{~mm}$. Apesar disto, em 60 minutos de ensaio, constatou-se uma coerente transferência de calor para a zona interna do material, inicialmente com as argamassas de gesso mais suscetíveis à elevação de temperatura do que as pastas de mesmo material, com posterior uniformidade ao longo de toda seção transversal após os 60 minutos, com temperatura média da ordem de $950{ }^{\circ} \mathrm{C}$, segundo o ilustrado na Figura 4.28.

Figura 4.28 - Elevação de temperatura em (a) pasta de gesso, com a/g =0,45 e (b) argamassa de gesso $1: 2$, com $\mathrm{a} / \mathrm{g}=0,70$ e areia fina

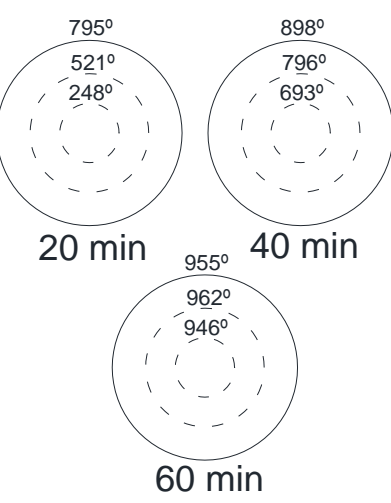

(a)

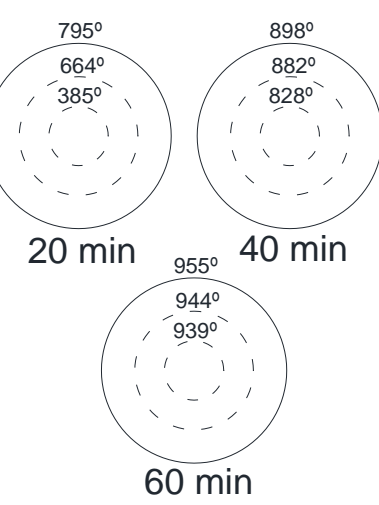

(b)

Fonte: Autor (2020).

Similarmente ao comentário anterior, este comportamento térmico também é influenciado pela maior porosidade que as argamassas de gesso possuem em relação às pastas. Barbosa et al. (2014) também chama atenção para o fato de que a maior porosidade na zona de transição da mistura tem ligação com a maior relação água/gesso utilizada para hidratação das argamassas, visto que a água remanescente do processo de hidratação ocupa um volume considerável entre os cristais e evapora, ocasionando o surgimento de vazios no material, conforme a Figura 4.29.

Figura 4.29 - Micrografias dos revestimento em gesso (a) pasta e (b) argamassa 1:2

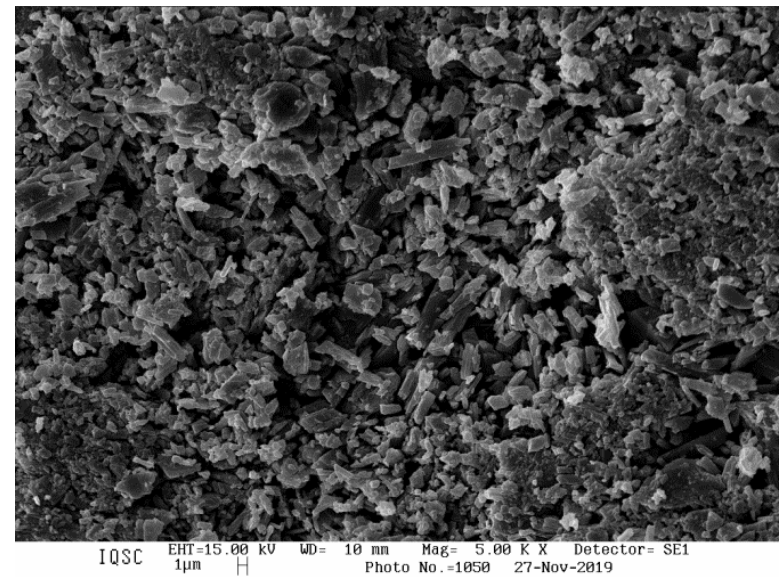

(a)

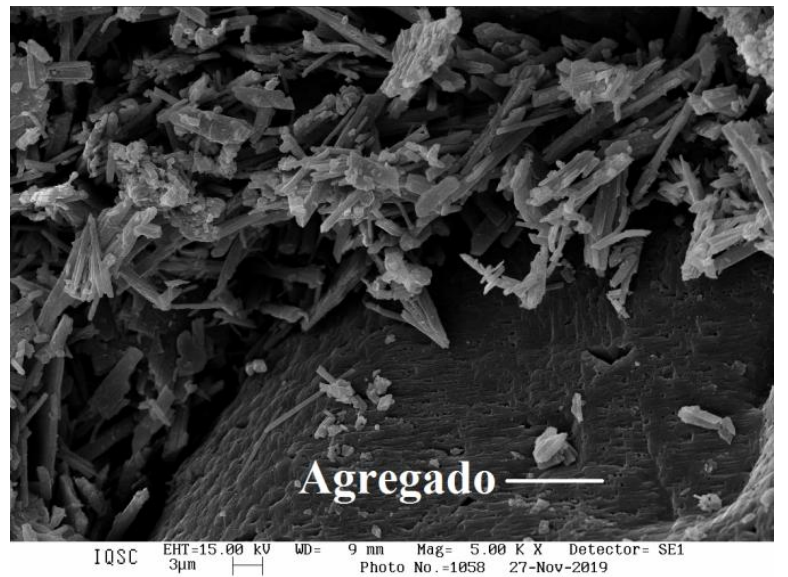

(b)

Fonte: Autor (2020). 
Após realização dos ensaios e obtenção da elevação de temperatura nos pontos de instrumentação, iniciou-se o processo de resfriamento dos corpos de prova, ilustrado na Figura 4.30. Decorridos os 120 minutos de ensaio, os queimadores foram desativados e o ventilador do forno permaneceu acionado durante aproximadamente quatro horas, para que a temperatura decrescesse de maneira uniforme. Devido à logística do Laboratório, os dispositivos precisaram ser desligados e, a partir disso, o resfriamento ocorreu de forma lenta e natural por aproximadamente mais 16 horas. Em instantes anteriores à abertura do forno, os ventiladores voltavam a ser acionados para redução imediata na temperatura interna, favorecendo a abertura do equipamento após 24 horas do início do ensaio, com uma temperatura variável entre $30{ }^{\circ} \mathrm{C}$ e $40{ }^{\circ} \mathrm{C}$.

Figura 4.30 - Ciclo típico de aquecimento e resfriamento dos ensaios de simulação de incêndio-padrão

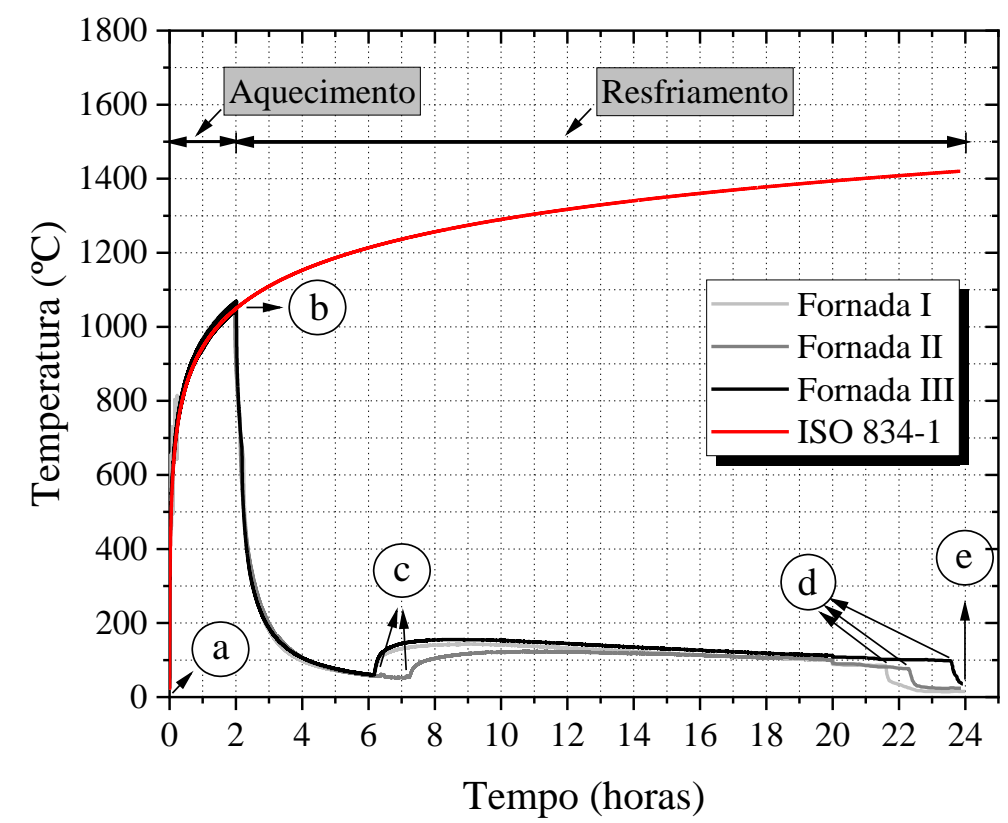

Fonte: Autor (2020).

Abaixo segue a descrição das principais etapas do ensaio, cuja indicação foi realizada na Figura 4.30.

a) Acionamento dos queimadores e início do ensaio;

b) Desligamento dos queimadores em decorrência da finalização do ensaio, e permanência dos ventiladores internos ligados;

c) Desligamento dos ventiladores internos do equipamento e início do processo de resfriamento natural;

d) Religamento dos ventiladores internos para diminuição de temperatura imediata;

e) Desligamento dos ventiladores internos e abertura do forno. 


\subsection{ISOLAMENTO TÉRMICO}

Conforme comentado nos itens anteriores, a realização dos ensaios das pequenas paredes compartimentadas através da configuração dos trios, e a instrumentação da região interna dos mesmos com utilização de cabos termopares, possibilitou uma avaliação aproximada do grau de compartimentação e isolamento térmico proporcionado pelos elementos estruturais de alvenaria com blocos cerâmicos.

As curvas de elevação de temperatura geradas pela instrumentação das pequenas paredes compartimentadas sem revestimento, apresentadas na Figura 4.25, possibilitaram a geração de superfícies de elevação de temperatura ao longo da largura dos dois tipos de blocos utilizados. As superfícies confirmaram de maneira qualitativa o maior grau de compartimentação e isolamento dos elementos de alvenaria constituídos por blocos de paredes maciças. Tomando como base o estudo experimental realizado por Nguyen e Meftah (2012), considera-se que este comportamento foi decorrente da presença de vazios ao longo da seção transversal com blocos de paredes vazadas, tendo em vista que a transferência de calor nessas unidades ocorre mais rapidamente através do ar interno nos vazios do que pelos septos.

A partir destas superfícies, observou-se que toda a seção transversal composta por blocos de paredes vazadas encontrava-se submetida a temperaturas superiores a $600{ }^{\circ} \mathrm{C}$ após aproximadamente 90 minutos de ensaio. Enquanto que nos elementos com blocos de paredes maciças, apenas metade da seção transversal atingiu esta mesma temperatura durante todo ensaio, conforme apresentado na Figura 4.31.

Figura 4.31 - Superfícies de elevação de temperatura na seção transversal das pequenas paredes sem revestimento compartimentadas com blocos de paredes (a) vazadas e (b) maciças

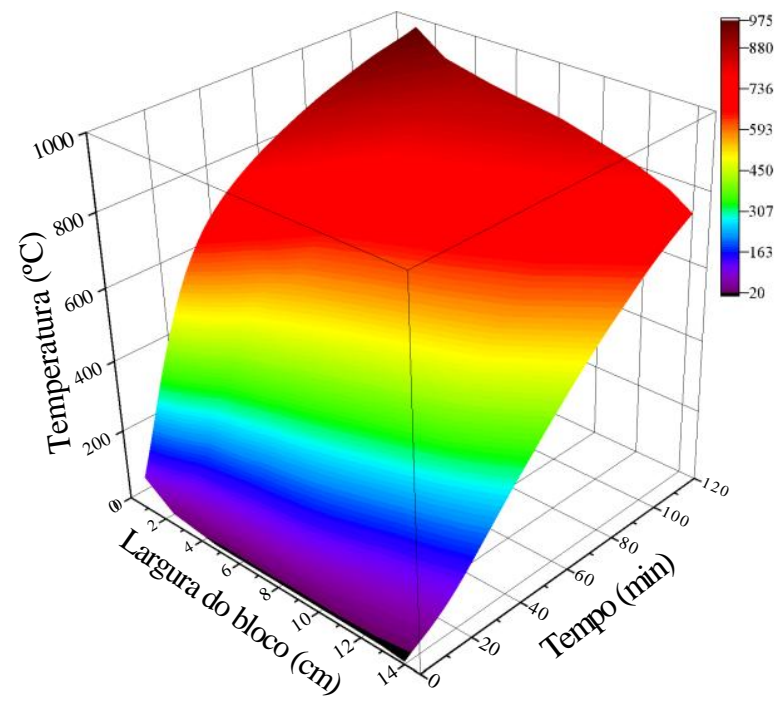

(a)

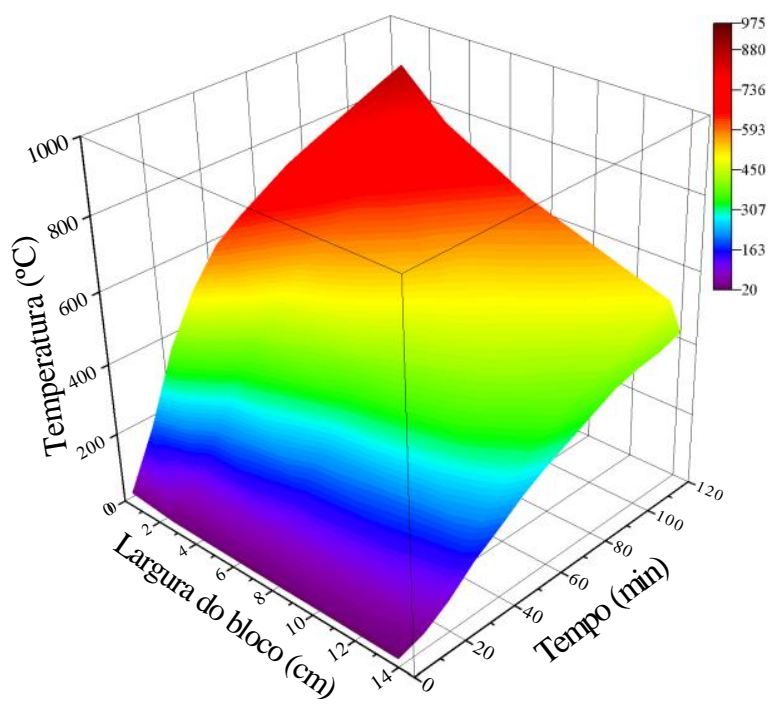

(b)

Fonte: Autor (2020). 
Nessa perspectiva, avaliou-se o critério de isolamento térmico conforme recomendação do Eurocode 6 Part 1-2:2005, considerando o seu atendimento quando a variação da temperatura interna dos trios permanecesse abaixo de $180{ }^{\circ} \mathrm{C}$. Considerando-se a temperatura ambiente de $22{ }^{\circ} \mathrm{C}$ no instante anterior à realização da fornada III, como indicado na Tabela 4.7, traçou-se uma reta sobre a temperatura final de $202{ }^{\circ} \mathrm{C}$ e analisou-se o tempo em que cada elemento levou para atingir essa temperatura, conforme ilustra a Figura 4.32.

Figura 4.32 - Elevação da temperatura interna dos trios de pequenas paredes compartimentadas

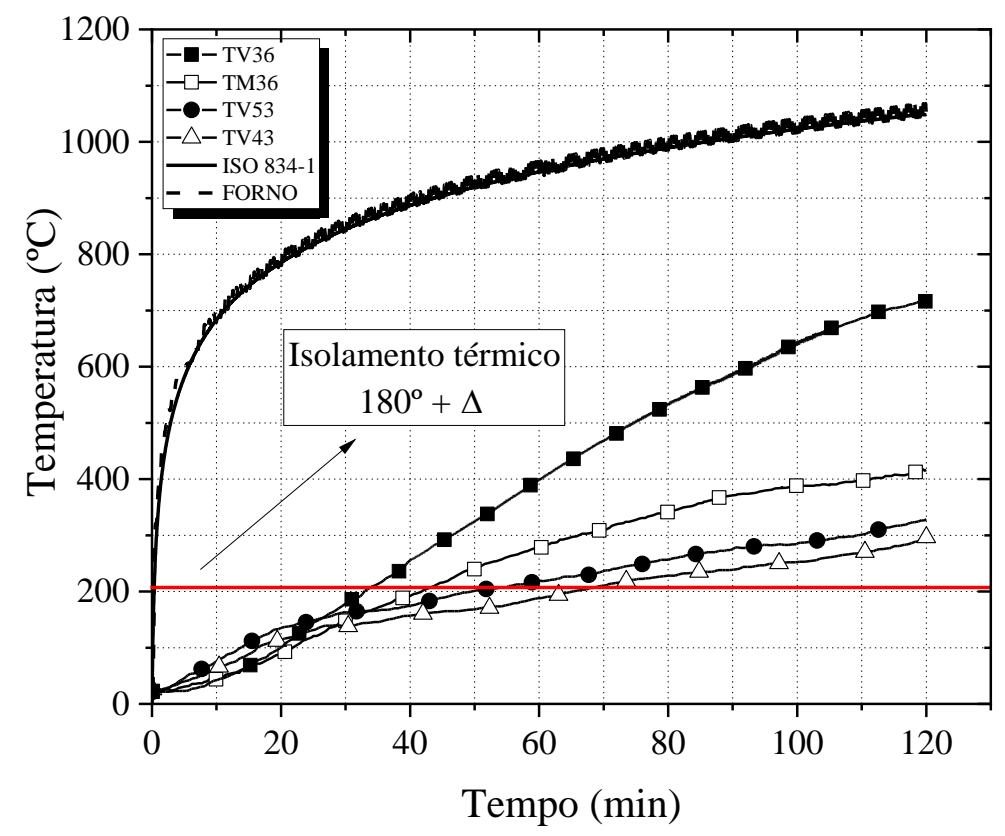

Fonte: Autor (2020).

A Tabela 4.14 apresenta esses resultados de maneira quantitativa, indicando o tempo do critério para as quatro situações de elementos compartimentados, pequenas paredes com blocos de paredes vazadas e maciças, e apenas os primeiros elementos revestidos com argamassa de cimento e gesso 1:2.

Tabela 4.14 - Critério de isolamento térmico

\begin{tabular}{ccc}
\hline $\begin{array}{c}\text { Tipo de corpo de } \\
\text { prova }\end{array}$ & Especificação & $\begin{array}{c}\text { Tempo } \\
\text { (min) }\end{array}$ \\
\hline \hline Blocos com & Sem revestimento & 33,4 \\
paredes vazadas & Revestidos com argamassa de cimento & 67,3 \\
\hline Blocos com & Revestidos com argamassa de gesso 1:2 & 51,2 \\
paredes maciças & Sem revestimento & 42,4 \\
\hline \hline Fonte: Autor (2020). & &
\end{tabular}

Conforme comentado anteriormente, os elementos estruturais compostos por blocos de paredes maciças apresentaram melhor isolamento térmico, e o tempo ao qual se ultrapassou o 
critério estabelecido foi aproximadamente $27 \%$ superior ao dos elementos com blocos de paredes vazadas. Naturalmente, os elementos estruturais revestidos apresentaram um maior isolamento térmico, sendo que o garantido pelo revestimento em argamassa de cimento foi de aproximadamente 67 minutos. Este tempo foi mais que o dobro daquele apresentado pelos mesmos elementos sem o revestimento, e manteve-se 31,4\% acima do tempo atingido quando o revestimento foi de argamassa de gesso. Os motivos devem-se ao fato da maior densidade e menor porosidade do material cimentício, conforme discutido com detalhes no item 4.5.

Acrescenta-se, ainda, que este tempo relativo ao critério de isolamento manteve-se inferior ao obtido em demais pesquisas com o mesmo material como em Rosemann (2011). Porém, salienta-se que o isolamento foi muito prejudicado pela excessiva deterioração que os elementos apresentaram durante o ensaio, o que provocou a abertura de fissuras significativas, favorecendo a rápida passagem de calor para a região interna dos trios de pequenas paredes, de acordo com o descrito no item 5.2.

\subsection{RESUMO DO CAPÍTULO}

Neste capítulo realizou-se a apresentação e descrição da etapa experimental em que as unidades e os elementos de alvenaria estrutural com blocos cerâmicos sujeitaram-se a uma elevação de temperatura seguindo a curva de incêndio-padrão proposta pela ISO 834-1:1999. No total, realizaram-se três ensaios simulação de incêndio-padrão em que argamassas de assentamento e revestimento, blocos, prismas e pequenas paredes, confeccionados conforme indicações do item 3.4.1, foram dispostos em um forno horizontal a gás por 120 minutos.

Para obtenção da elevação de temperatura ao longo da seção transversal, os diferentes corpos de prova tiveram suas respectivas seções instrumentadas com auxílio de cabos termopares em diferentes pontos ao longo da largura dos blocos, analisados segundo as duas geometrias tratadas neste trabalho, com paredes vazadas e maciças.

A transferência de calor e elevação de temperatura mostraram-se consistentes durante os ensaios, com aumento gradativo de temperatura conforme incremento de tempo e aproximação das faces sujeitas a ação do fogo. Devido à diferença entre as dimensões dos corpos de prova, blocos e prismas não apontaram diferenças significativas no comportamento térmico, e apresentaram temperaturas ligeiramente inferiores daquelas apresentadas pelas pequenas paredes de alvenaria.

Por sua vez, avaliaram-se as pequenas paredes sob suas situações distintas, sendo uma delas com atuação do fogo em todas as faces dos elementos isolados, e a outra com atuação 
do fogo apenas em uma das faces longitudinais, para avaliar a compartimentação e isolamento térmico das mesmas. De modo geral, os elementos compostos por blocos cerâmicos de paredes maciças apresentaram grau de isolamento térmico $27 \%$ superior em relação aos mesmos corpos de prova constituídos de blocos com paredes vazadas.

Para a configuração de pequenas paredes com blocos de paredes vazadas, devido ao menor isolamento observado, aplicaram-se dois tipos de revestimento em argamassas de cimento e gesso. Através da obtenção da elevação de temperatura em termopares instalados na região interna dos trios, observou-se como benéfica a incorporação de ambos os revestimentos, tendo em vista que o critério de isolamento térmico em ambas as situações foi ultrapassado apenas aos 67 e 51 minutos, respectivamente, para os elementos revestidos com argamassas de cimento e gesso, em relação ao tempo de 33 minutos obtido quando os mesmos elementos não foram revestidos.

A partir de ensaios com auxílio de Microscopia Eletrônica por Varredura (MEV), Observou-se uma formação mais densa nos materiais cimentícios, em comparação com materiais em gesso que apontaram maior porosidade da mistura, sobretudo nas zonas de transição entre a pasta e os agregados. No mesmo contexto, a incorporação de agregados na composição do gesso favoreceu a passagem de calor no material.

Ademais, esta etapa do programa experimental apresentou-se como indispensável para avaliação do comportamento térmico dos elementos de alvenaria estrutural, assim como para o entendimento do desempenho térmico dos materiais envolvidos no trabalho, como a cerâmica, e as argamassas de cimento e gesso. 


\section{PROGRAMA EXPERIMENTAL III - AVALIAÇÃO DO COMPORTAMENTO RESIDUAL}

\subsection{CONSIDERAÇÕES INICIAIS}

Após a submissão dos elementos de alvenaria estrutural à situação de incêndio, realizaram-se ensaios mecânicos de compressão simples e módulo de elasticidade para avaliação do comportamento mecânico residual de argamassas de assentamento, blocos, prismas e pequenas paredes de alvenaria com blocos cerâmicos, e identificação da influência da elevação de temperatura nas propriedades residuais destes materiais.

Os ensaios mecânicos residuais foram realizados no Laboratório de Estruturas da Escola de Engenharia de São Carlos (LE - EESC) conforme descritos nos itens 3.2.3 e 3.4.2, utilizando-se a mesma especificação e quantidade de corpos de prova. Por comodidade, a descrição e apresentação dos ensaios foram realizadas novamente neste capítulo que, em geral, destinou-se à verificação do comportamento mecânico residual e apresentou detalhes quanto ao estado de danificação dos elementos após simulações de incêndio-padrão. Além disso, foram examinados através de imagens microscópicas, os principais detalhes quanto às modificações nos materiais cerâmicos e cimentícios e a influência destas no comportamento dos componentes estruturais.

\subsection{DANIFICAÇÃO DOS MATERIAIS}

De modo geral, quando submetidos a situações excepcionais como o incêndio, os elementos estruturais usuais utilizados na construção civil apresentam elevada danificação e alterações na composição dos materiais que o constituem. Assim, o grande prejuízo manifestado nas propriedades mecânicas destes elementos compromete o seu funcionamento e atendimento às solicitações para as quais foi disposto.

Para os elementos de alvenaria estrutural com blocos cerâmicos analisados neste trabalho, durante a realização das simulações de incêndio-padrão descritos no capítulo 4, alguns instantes do ensaio puderam ser acompanhados através de um pequeno visor acoplado à superfície externa do forno. Através deste, observou-se o processo de queima dos corpos de prova durante o período em que os queimadores estiveram ativos, constatando o alto grau de deterioração nos mesmos, ocasionado pela elevação rápida de temperatura, conforme ilustrado na Figura 5.1. 
Figura 5.1 - Danificação em elementos de alvenaria durante simulação de incêndio-padrão
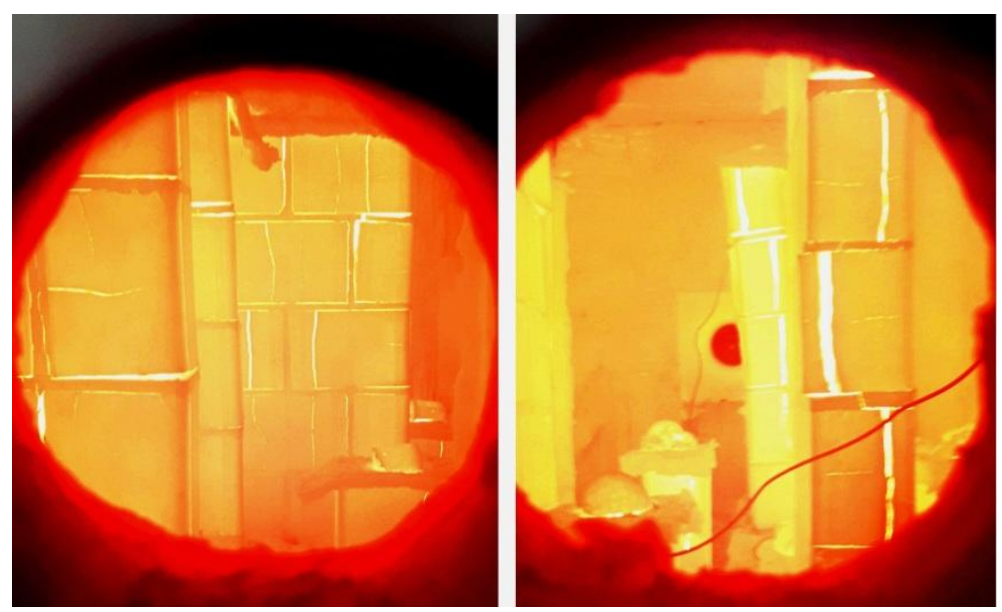

Fonte: Autor (2020)

A partir de 30 minutos de ensaio, observaram-se estalos internos que indicavam o processo de fratura dos materiais, hipótese que foi confirmada ao fim do ensaio e abertura do forno. Após a elevação de temperatura no ensaio de incêndio-padrão, os blocos apresentaram elevado grau de fissuração. As fissuras desenvolveram-se predominantemente na direção da altura do bloco, e de forma distribuída em todas as faces de ambos os tipos de blocos, promovendo o completo desmembramento das unidades em partes distintas, conforme apresentado na Figura 5.2.

Figura 5.2 - Aspecto superficial dos blocos com paredes (a) vazadas e (b) maciças após situação de incêndio

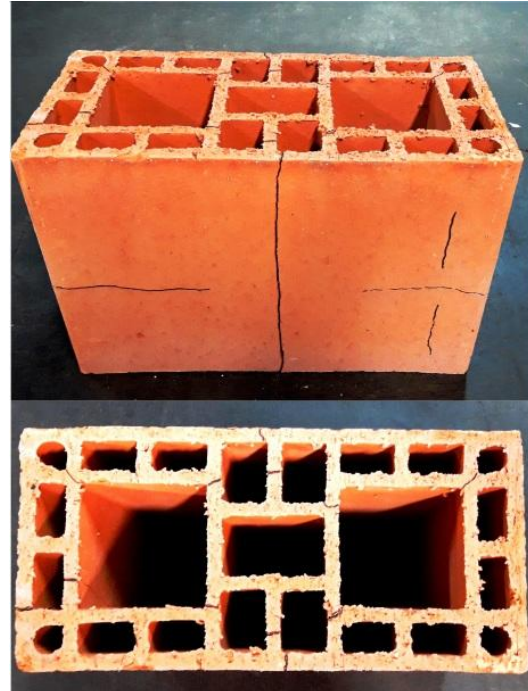

(a)

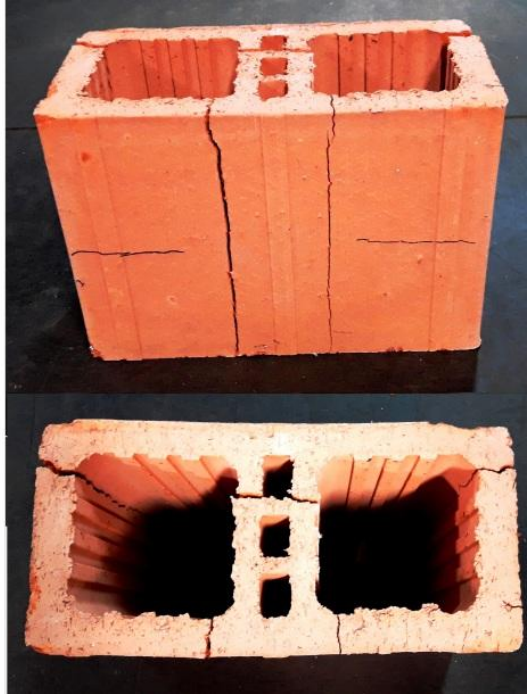

(b)

Fonte: Autor (2020).

As fissuras ocorreram tanto nas paredes longitudinais, quanto nas paredes transversais dos blocos, com maior incidência em regiões próximas às interseções entre as paredes externas e septos. Nguyen e Meftah (2012) descrevem que concentração das tensões térmicas 
e a dilatação diferencial entre duas paredes externas ou septos dos blocos, pode ser a principal influência para o destaque das fissuras nessa região. Os mesmos autores indicam, inclusive, que tais dilatações térmicas podem ocasionar o surgimento de tensões de tração na direção horizontal, culminando na abertura de fissuras.

Contudo, não foram observados indícios de degradação no material cerâmico, que permaneceu rígido e com alta dureza. Segundo Dutra (2007), o aparecimento de fissuras no material cerâmico também sofre influência da velocidade de aquecimento da temperatura. Acrescenta-se ainda que, embora com temperaturas mais amenas, os blocos cerâmicos de alvenaria estrutural submeteram-se anteriormente ao processo de queima durante a própria fabricação.

Nos elementos isolados de alvenaria estrutural, a magnitude das fissuras permaneceu a mesma, adicionando-se o acréscimo da degradação das juntas de argamassa de assentamento, conforme ilustrado na Figura 5.3. Além do mais, a deformação diferencial entre a junta de argamassa e a unidade cerâmica favoreceu a segregação dos dois na interface bloco/junta, principalmente nas últimas fiadas das pequenas paredes isoladas.

Figura 5.3 - Aspecto superficial dos (a) prismas e (b) pequenas paredes isoladas após situação de incêndio

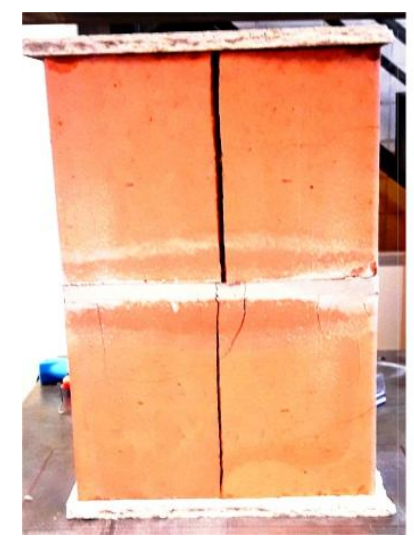

(a)

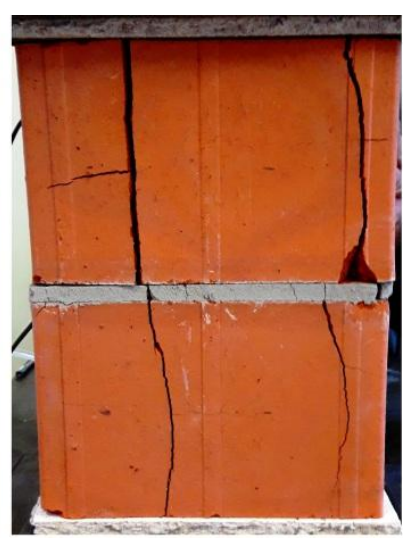

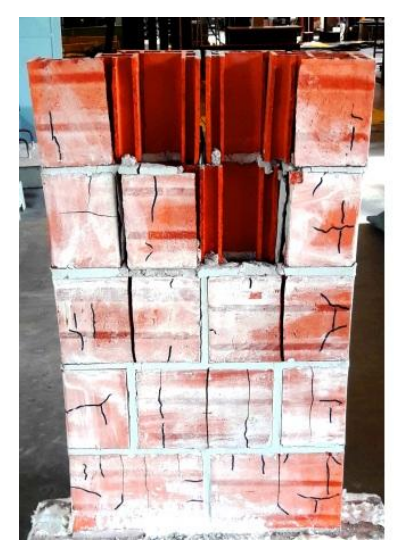

(b)

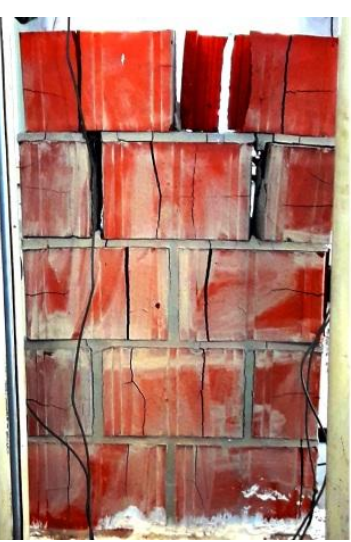

Fonte: Autor (2020).

As dimensões dos elementos também favoreceram a sua danificação devido aos fenômenos de instabilidade associados à distribuição desalinhada das fissuras, que provocou o destacamento das unidades no decorrer do ensaio em função da movimentação e velocidade dos gases quentes no interior do forno, como pode ser visto na Figura 5.3 (b). Este fator também impossibilitou a realização de ensaios mecânicos nas pequenas paredes isoladas.

Nesse contexto, Rosemann (2011) atribui as fissuras verticais à dilatação térmica causada pelo aquecimento, e afirma que a ausência de carregamento implica no aumento das 
fissuras e das deformações nos elementos sujeitos à elevação de temperatura, devido à inexistência das restrições asseguradas pelos apoios ou aplicação do carregamento.

O maior grau de compartimentação das pequenas paredes com blocos de paredes maciças também foi certificado mediante avaliação do padrão de fissuras em ambas as pequenas paredes compartimentadas ilustrado na Figura 5.4. Além disso, notou-se uma diferença significativa entre as faces expostas e não expostas ao fogo, bem como em relação às pequenas paredes isoladas que foram apresentadas na Figura 5.3 (b), destacando a importância dos elementos compartimentados no comportamento térmico e mecânico.

Figura 5.4 - Aspecto superficial das pequenas paredes sem revestimento compartimentadas com blocos de paredes (a)/(c) vazadas e (b)/(d) maciças após situação de incêndio

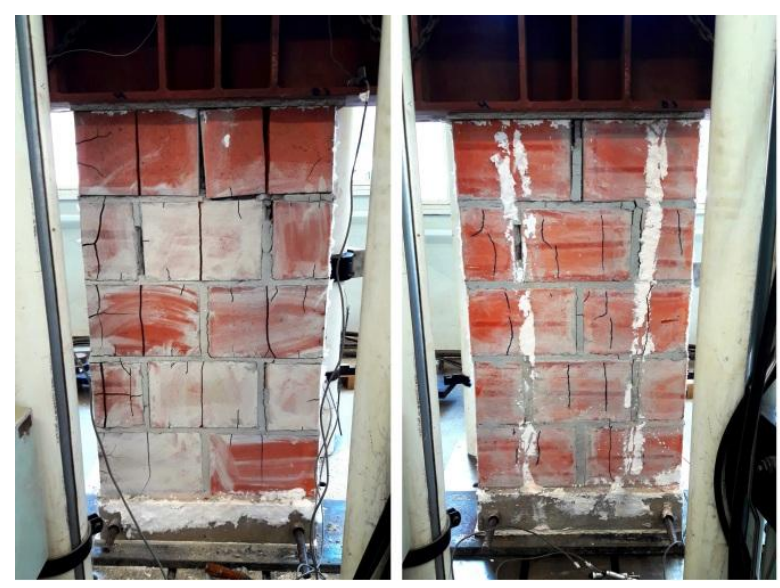

Faces expostas ao fogo

(a) (b)

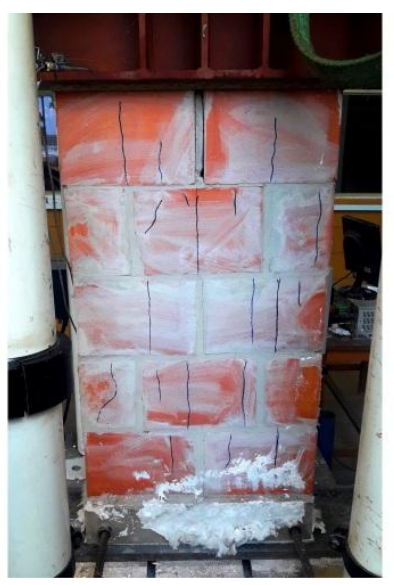

Faces não expostas ao fogo

(c)

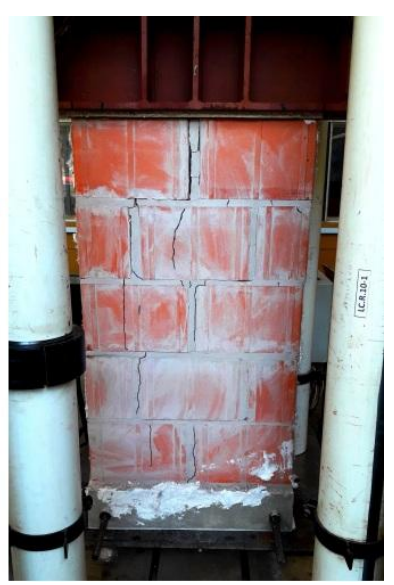

(d)

Fonte: Autor (2020).

A incorporação de camadas de revestimento em ambas as faces das pequenas paredes compartimentadas com blocos de paredes vazadas contribuiu consideravelmente na proteção do elemento de alvenaria, ocasionando o aparecimento de um número reduzido de fissuras, sobretudo na face não exposta ao fogo, conforme apresentado na Figura 5.5. Do mesmo modo, comparando-se as faces expostas ao fogo dos elementos revestidos com a mesma configuração de pequenas paredes sem revestimento (Figura 5.4 (a)), notou-se que ambos os tipos de revestimento foram eficazes nas faces expostas ao fogo, reduzindo o panorama de fissuras devido à elevação de temperatura, conforme observado no comportamento térmico tratado no item 4.5.

Quanto ao aspecto final dos revestimentos após as simulações de incêndio-padrão, observou-se que as camadas de revestimento dispostas nas faces expostas ao fogo foram muito danificadas e em diversas regiões dos elementos ocorreu o desplacamento da camada, como mostrado na Figura 5.6. 
Figura 5.5 - Aspecto superficial das pequenas paredes compartimentadas revestidas com argamassas de (a)/(c) cimento e (b)/(d) gesso após situação de incêndio

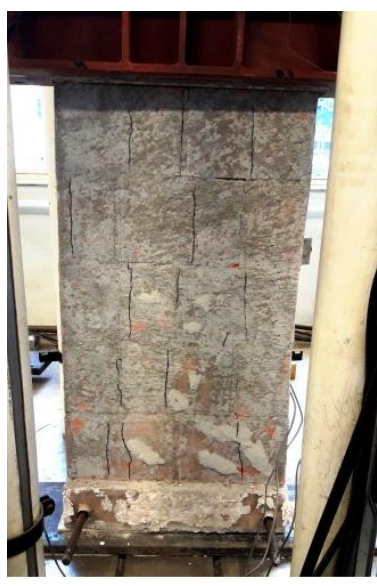

Faces expostas ao fogo

(a)

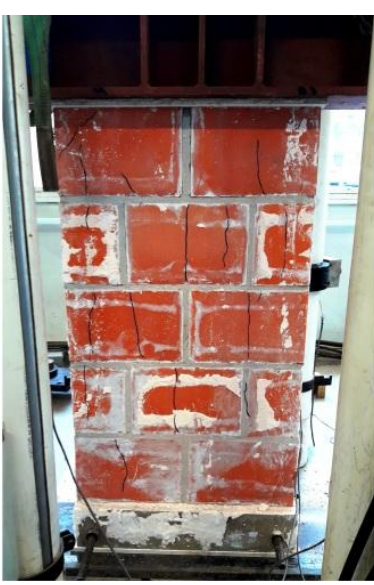

(b)

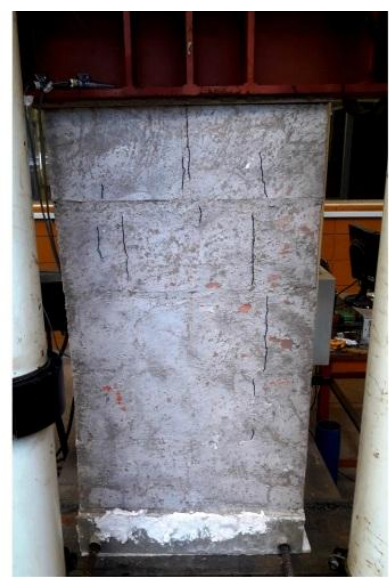

Faces não expostas ao fogo

(c)

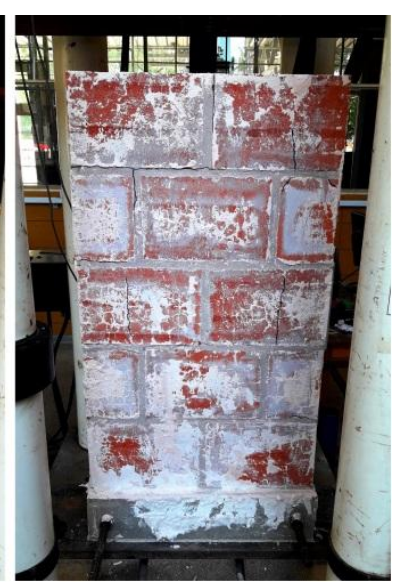

(d)

Fonte: Autor (2020).

Apesar do desplacamento de algumas camadas de revestimento nas faces expostas ao fogo, a aderência entre o revestimento e o substrato de alvenaria manteve-se eficiente nas faces internas que não estiveram em contato direto com as chamas, conforme ilustra a Figura 5.6. Devido à logística durante o ensaio e dificuldade de observação dos corpos de prova perante seu posicionamento dentro do forno, não foi possível identificar com clareza o instante em que o desplacamento ocorreu.

Figura 5.6 - Aspecto superficial das camadas de revestimento em argamassas de (a)/(c) cimento e (b)/(d) gesso após situação de incêndio

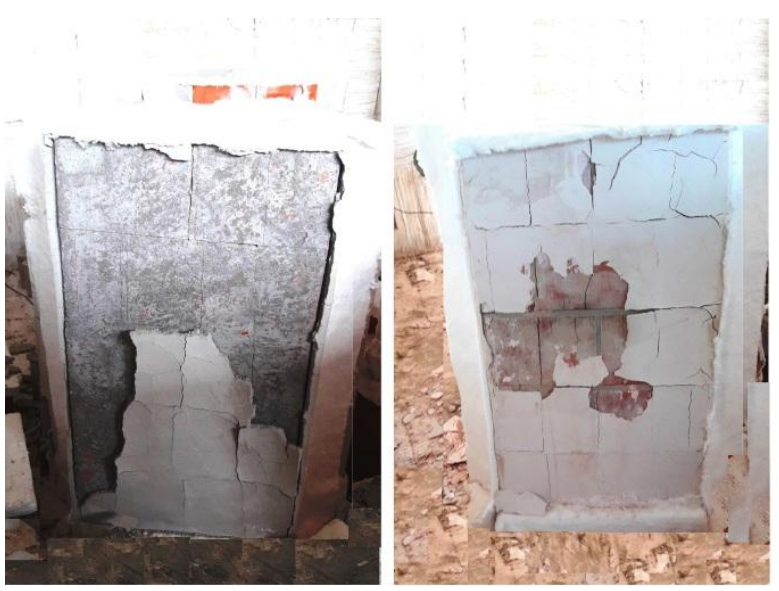

Faces expostas ao fogo

(a) (b)

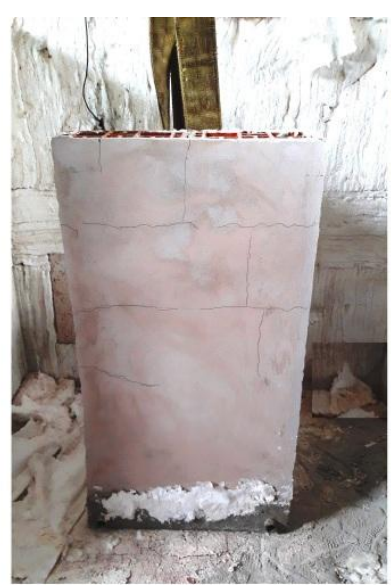

Faces não expostas ao fogo

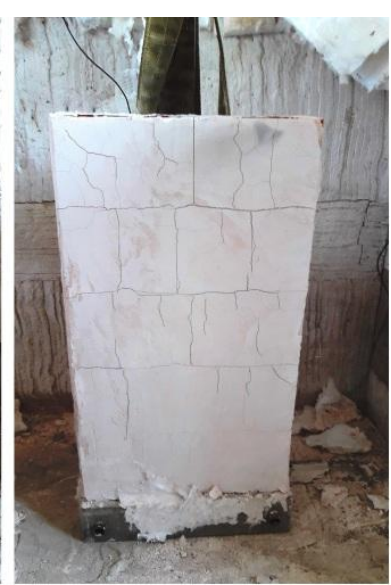

Fonte: Autor (2020).

(d)

(c)

\section{d)}

De modo geral, devido à elevação repentina de temperatura e rápida manifestação de fissuras, o critério de isolamento térmico dos elementos foi comprometido, uma vez que a abertura das fissuras favoreceu a passagem de gases para a região interna dos trios. 


\subsection{ENSAIOS DE COMPRESSÃO SIMPLES E MÓDULO DE ELASTICIDADE}

Avaliou-se o comportamento mecânico de todos os elementos submetidos à situação de incêndio mediante ensaios mecânicos de resistência à compressão e determinação de módulo de elasticidade. Os ensaios foram realizados após o completo resfriamento dos materiais, que permaneceram sujeitos à temperatura e umidade ambientes até a idade dos ensaios, sete dias após a realização da respectiva simulação de incêndio-padrão, com exceção das argamassas de assentamento que foram avaliadas em três idades diferentes.

Para realização dos ensaios de compressão, adotaram-se os mesmos procedimentos e instrumentação descritos nos itens 3.3.3, 3.2.3 e 3.4.2 para as argamassas de assentamento, blocos cerâmicos e elementos de alvenaria estrutural, revestimentos. A seguir, tem-se a descrição e apresentação dos resultados para cada componente ou elemento estrutural.

\subsubsection{Argamassa de assentamento}

Conforme o apresentado pela Tabela 4.2, após as simulações de incêndio-padrão foram ensaiados 30 corpos de prova cilíndricos com dimensões 50 x $100 \mathrm{~mm}$ da argamassa de assentamento com traço 1:0,5:4,5 em volume de cimento, cal e areia fina, utilizada na confecção dos elementos de alvenaria estrutural. Para estas argamassas, realizaram-se os ensaios mecânicos em três idades distintas (1, 3 e 7 dias) a partir da execução da fornada I, objetivando avaliar a influência do fenômeno da reidratação no comportamento mecânico das mesmas.

Os ensaios mecânicos das argamassas de assentamento foram realizados com auxílio de uma máquina Instron Satec ${ }^{\circledR}$, modelo 300 HVL, e capacidade nominal de 1500 kN. Os ensaios foram realizados com controle de deslocamento a uma velocidade de $0,005 \mathrm{~mm} / \mathrm{s}$ e todos os corpos de prova foram instrumentados com dois clip-gages com $50 \mathrm{~mm}$ de base.

Figura 5.7 - Ensaio de resistência à compressão em argamassa após situação de incêndio

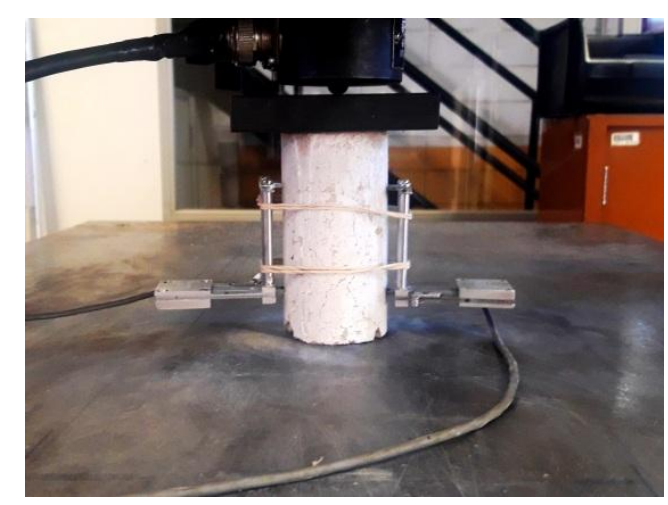

Fonte: Autor (2020). 
Devido à baixa resistência mecânica dos materiais cimentícios após sujeitarem-se a temperaturas elevadas, empregou-se uma célula de carga mais sensível com capacidade para $5 \mathrm{kN}$, para que fosse possível obter valores consistentes de carga, facilitando a obtenção dos diagramas tensão x deformação, que por sua vez foram obtidos com utilização dos clip-gages indicados na Figura 5.7. Os diagramas tensão x deformação para as três idades avaliadas foram apresentados na Figura 5.8.

Figura 5.8 - Diagramas tensão x deformação da argamassa de assentamento ensaiadas (a) 1 dia (b) 3 dias e (c) 7 dias após situação de incêndio

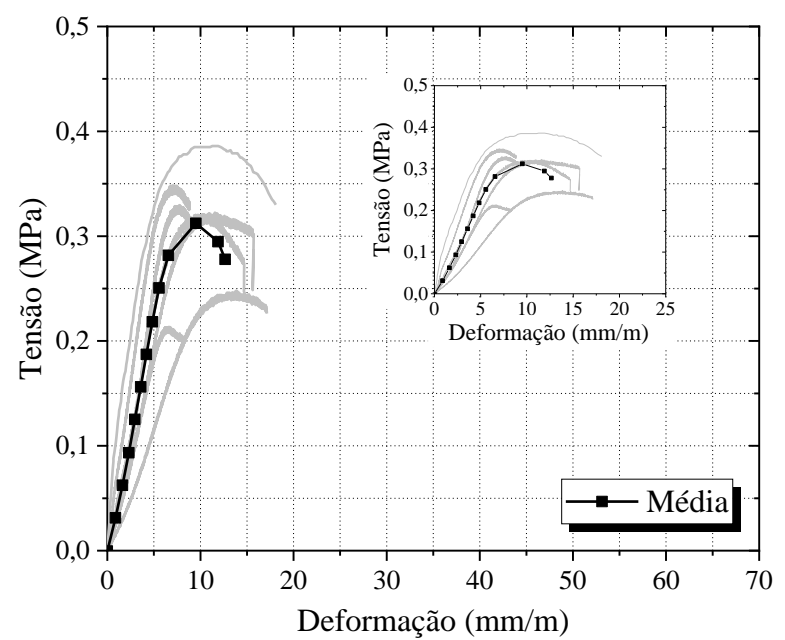

(a)

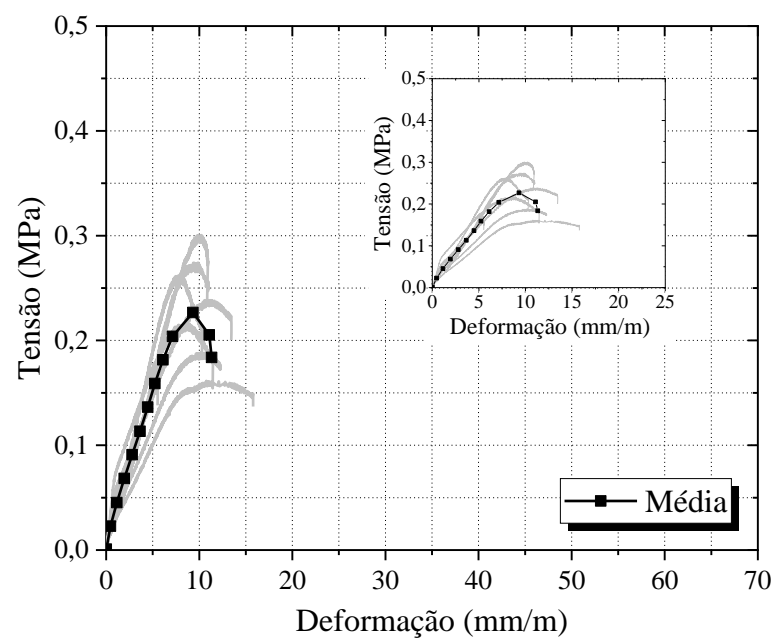

(b)

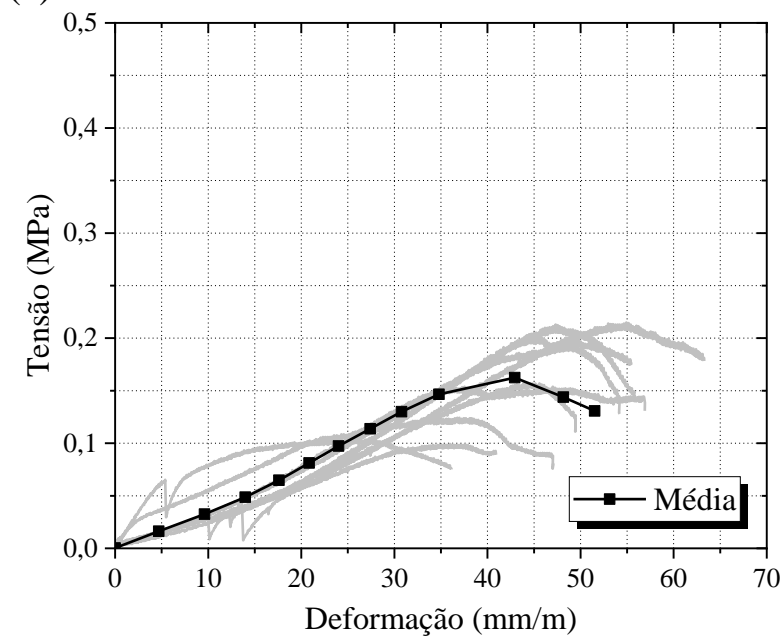

(c)

Fonte: Autor (2020).

Para obtenção do módulo de elasticidade, de maneira similar ao realizado anteriormente para as argamassas de assentamento em temperatura ambiente, utilizaram-se as recomendações do ACI 530-05:2005, obtendo o módulo de elasticidade secante no trecho do diagrama tensão x deformação compreendido entre 5\% e 33\% da tensão máxima.

A Tabela 5.1 indica os resultados médios obtidos para a caracterização das propriedades mecânicas das argamassas conforme variação na idade do ensaio. 
Tabela 5.1 - Propriedades mecânicas da argamassa de assentamento após situação de incêndio

\begin{tabular}{cccccc}
\hline \hline & Idade & Força $(\mathbf{k N})$ & $\boldsymbol{f}_{\mathbf{a}}(\mathbf{M P a})$ & $\boldsymbol{\varepsilon}_{\boldsymbol{p}}(\mathbf{m m} / \mathbf{m})$ & $\boldsymbol{E}_{\mathbf{a}}(\mathbf{G P a})$ \\
\hline \hline Média & \multirow{2}{*}{1 dia } & 0,615 & 0,312 & 9,52 & 0,047 \\
DP & 0,11 & 0,06 & - & 0,02 \\
CV $(\%)$ & & 18,05 & 18,05 & - & 48,23 \\
\hline Média & \multirow{2}{*}{3 dias } & 0,445 & 0,227 & 9,32 & 0,038 \\
DP & & 0,10 & 0,05 & - & 0,02 \\
CV $(\%)$ & 22,48 & 22,48 & - & 46,93 \\
Média & & 0,319 & 0,162 & 42,93 & 0,004 \\
DP & 7 dias & 0,09 & 0,047 & & 0,001 \\
CV $(\%)$ & & 28,74 & 28,74 & & 31,77 \\
\hline \hline
\end{tabular}

Fonte: Autor (2020).

De modo geral, as argamassas de assentamento apresentaram resistência à compressão muito baixa após a situação de incêndio. A sua resistência residual variou entre 7,1\%, 5,2\% e 3,7\% para os ensaios realizados 1, 3 e 7 dias após a situação de incêndio, respectivamente. As observações inerentes ao fenômeno da reidratação foram realizadas no item 5.4 deste trabalho.

Destaca-se ainda a alta deformabilidade das argamassas de assentamento após estarem submetidas às condições de incêndio, o que também foi observado por Alves (2018), Zegarra (2018) e Yao et al. (2017). Este comportamento apontou influência significativa na deformação dos elementos de alvenaria apresentados posteriormente, e na forma de ruptura das argamassas que resultou na decomposição parcial dos corpos de prova em diversos fragmentos, devido à sua característica quebradiça, conforme ilustrado na Figura 5.9.

Figura 5.9 - Modo de ruptura das argamassas de assentamento em (a) temperatura ambiente e (b) 7 dias após situação de incêndio

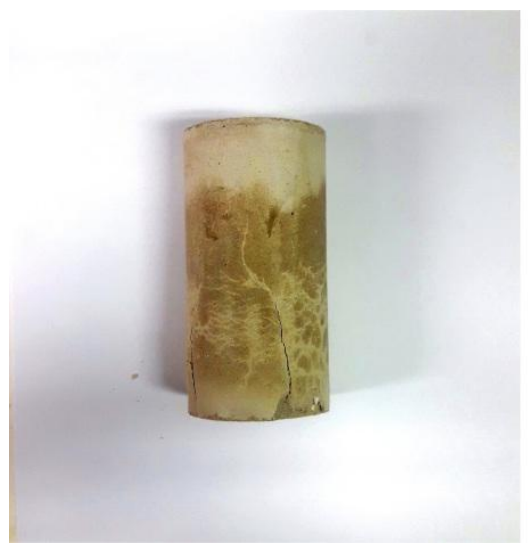

(a)

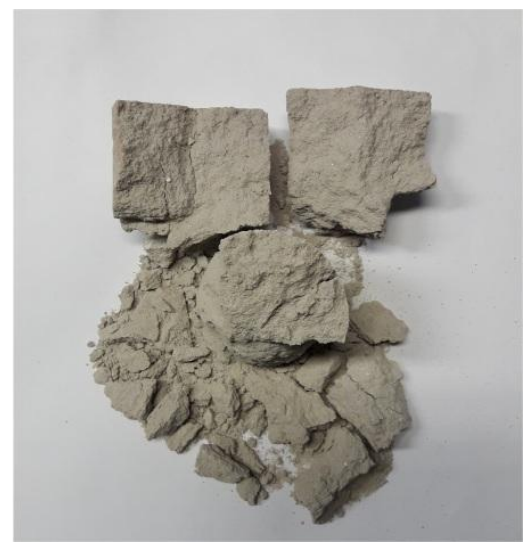

(b) 


\subsubsection{Unidades cerâmicas}

Os blocos cerâmicos de alvenaria estrutural foram submetidos ao ensaio de compressão simples sete dias após a realização do ensaio de simulação de incêndio-padrão na fornada I. No total, 13 corpos de prova de cada geometria foram ensaiados de maneira semelhante a aquela realizada para os blocos que permaneceram em temperatura ambiente, descritos no item 3.2.3.1.

Os corpos de prova foram ensaiados em uma máquina Instron Satec ${ }^{\circledR}$, modelo 300 HVL, e capacidade nominal de $1500 \mathrm{kN}$, com controle de deslocamentos a uma velocidade de $0,02 \mathrm{~mm} / \mathrm{s}$. Previamente, instrumentaram-se todos os corpos de prova com dois clip-gages alternados nas duas faces longitudinais, conforme ilustrado na Figura 5.10.

Figura 5.10 - Ensaio de resistência à compressão em bloco após situação de incêndio

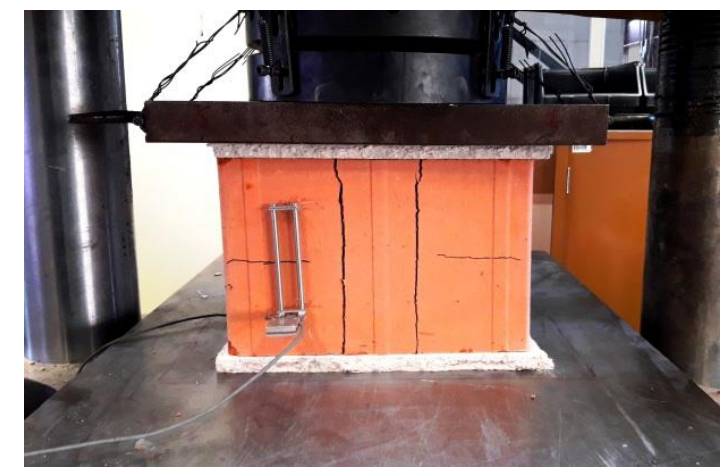

Fonte: Autor (2020).

Dessa maneira, possibilitou-se a aquisição de dados quanto à deformação das unidades e obtenção dos diagramas tensão x deformação apresentados na Figura 5.11.

Figura 5.11 - Diagramas tensão x deformação dos blocos com paredes (a) vazadas e (b) maciças após situação de incêndio

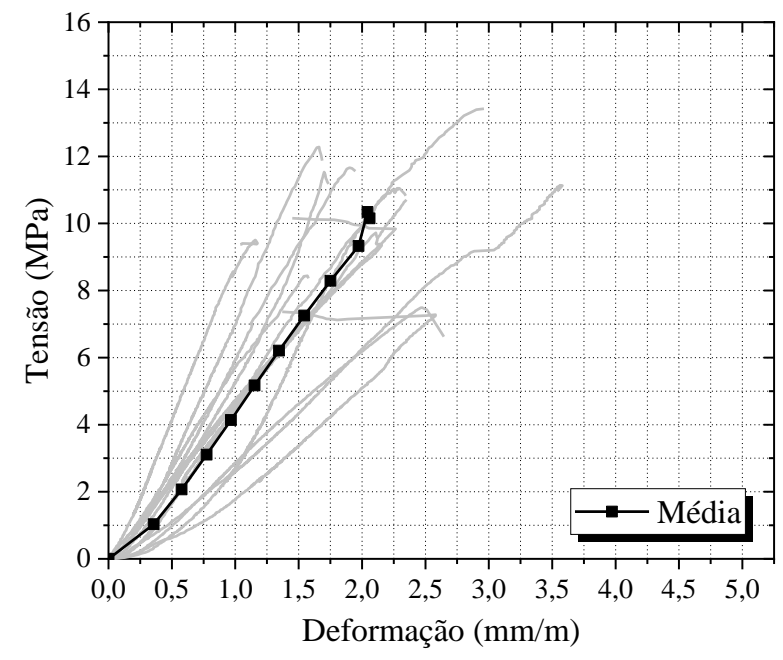

(a)

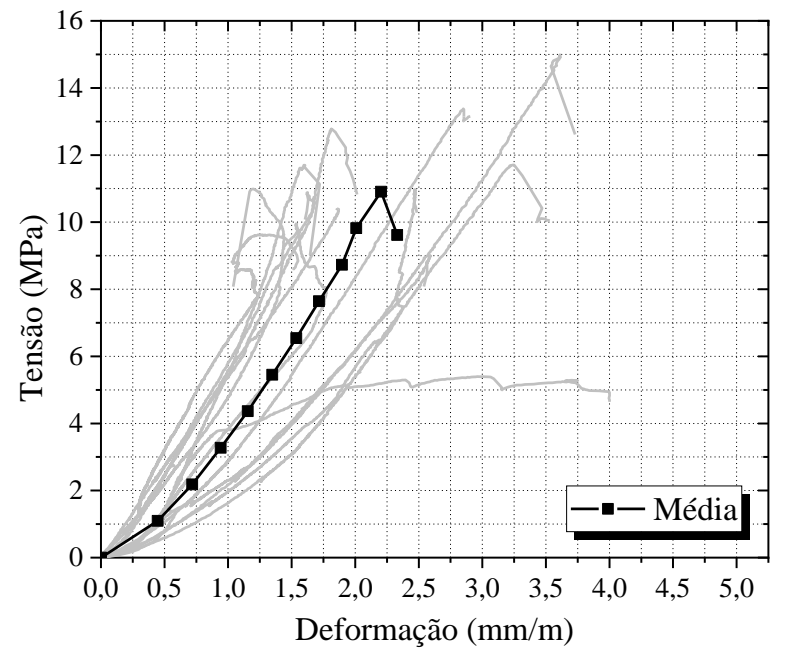

(b)

Fonte: Autor (2020). 
Para ambas as unidades, a obtenção do módulo de elasticidade foi realizada através da inclinação dos diagramas tensão x deformação de todos os corpos de prova, no trecho situado entre $5 \%$ e $33 \%$ da tensão de ruptura dos respectivos blocos cerâmicos, conforme preconiza o ACI 530-05:2005.

A Tabela 5.2 apresenta os resultados médios e característicos referentes à caracterização mecânica dos blocos cerâmicos após a situação de incêndio, com a resistência característica calculada a partir das recomendações da ABNT NBR 15270-1:2017.

Tabela 5.2 - Resistência à compressão e módulo de elasticidade dos blocos cerâmicos após situação de incêndio

\begin{tabular}{cccccc}
\hline \hline & $\begin{array}{c}\text { Força } \\
(\mathbf{k N})\end{array}$ & $\begin{array}{c}\text { Resistência na } \\
\boldsymbol{A}_{\text {bruta }}(\mathbf{M P a})\end{array}$ & $\begin{array}{c}\text { Resistência na } \\
\boldsymbol{A}_{\text {liq }}(\mathbf{M P a})\end{array}$ & $\begin{array}{c}\text { E na } \boldsymbol{A}_{\text {bruta }} \\
(\mathbf{G P a})\end{array}$ & $\begin{array}{c}\text { E na } \boldsymbol{A}_{\text {liq }} \\
(\mathbf{G P a})\end{array}$ \\
\hline \hline Média & 420,55 & 10,34 & 28,14 & 5,17 & 14,07 \\
$\mathbf{D P}$ & 73,68 & 1,81 & 4,93 & 1,68 & 4,57 \\
$\mathbf{C V}(\boldsymbol{\%})$ & 17,52 & 17,52 & 17,52 & 32,53 & 32,53 \\
$\mathbf{f}_{\text {bk }}$ & - & 7,29 & 19,84 & - & - \\
\hline \hline & \multicolumn{6}{c}{ Blocos cerâmicos com paredes vazadas } \\
\hline \hline Média & 450,25 & 10,90 & 22,29 & 10,02 \\
DP & 95,63 & 2,32 & 4,74 & 4,90 & 3,68 \\
CV $(\boldsymbol{\%})$ & 21,24 & 21,24 & 21,24 & 1,80 & 36,69 \\
$\mathbf{f}_{\text {bk }}$ & - & 6,86 & 14,03 & - & - \\
\hline \hline
\end{tabular}

Fonte: Autor (2020).

Conforme observado na Tabela 5.2, os blocos cerâmicos estruturais apresentaram elevada resistência à compressão mesmo após sujeitarem-se aos ensaios de simulação de incêndio-padrão. Notou-se que as fissuras principais ao longo da altura do bloco possuíram pouca influência na resistência mecânica dos mesmos. Embora com a presença das aberturas de fissuras que desmembraram por completo as unidades, acredita-se que devido ao nível de carregamento aplicado durante o ensaio, as placas de apoio proporcionaram um elevado confinamento aos corpos de prova, minorando a influência das fissuras.

Em contrapartida, as fissuras horizontais que foram observadas promoveram uma acomodação inicial nos diagramas tensão x deformação, como pode ser visto na Figura 5.11 no trecho entre as deformações de 0,0 a $0,5 \mathrm{~mm} / \mathrm{m}$. Esta acomodação inicial provocou uma redução discreta no módulo de elasticidade das unidades, que apresentou alto coeficiente de variação.

A ruptura de ambos os tipos de blocos ocorreu de maneira brusca, caracterizada pelo comportamento frágil do material cerâmico. Eles romperam predominantemente por 
esmagamento do material ou pela instabilidade das paredes externas em decorrência das aberturas de fissuras pré-existentes devido ao processo de elevação de temperatura. Na Figura 5.12 podem ser vistos os principais modos de ruptura apresentados.

Figura 5.12 - Modo de ruptura das unidades cerâmicas após situação de incêndio
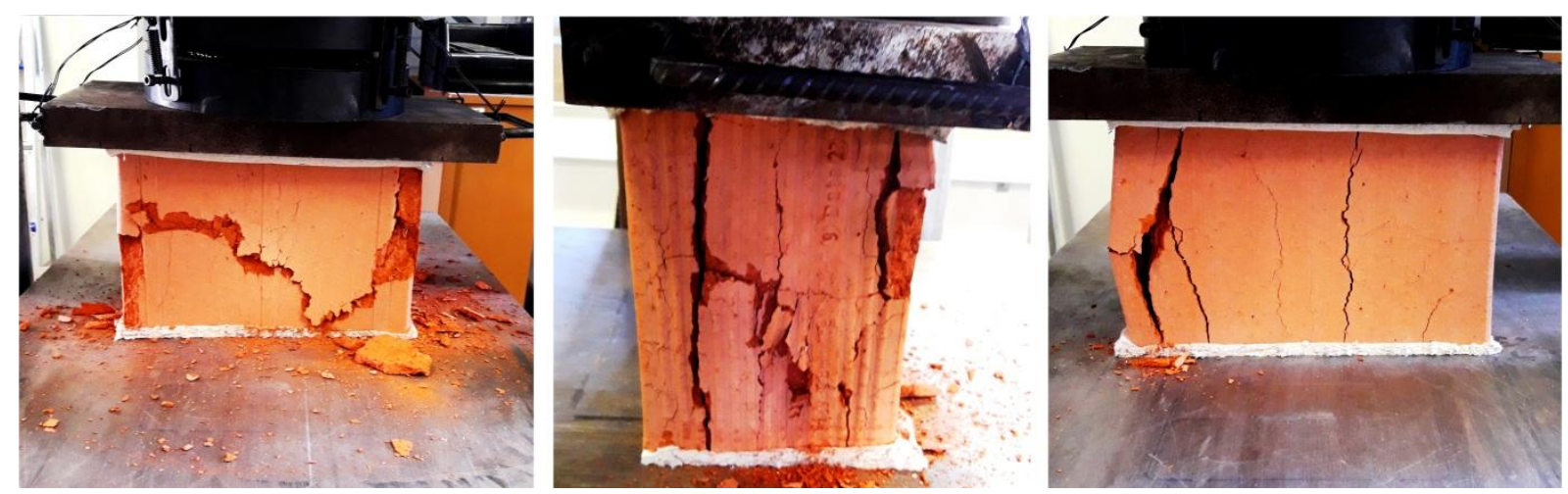

Fonte: Autor (2020).

\subsubsection{Elementos de alvenaria estrutural}

Para avaliação do comportamento mecânico residual nos elementos de alvenaria estrutural, prismas e pequenas paredes foram submetidos a ensaios mecânicos para obtenção da resistência à compressão e módulo de elasticidade. Ensaiaram-se seis prismas e três pequenas paredes de cada série analisada.

Os prismas foram ensaiados através de um equipamento servo-hidráulico Instron Satec $^{\circledR}$, modelo $300 \mathrm{HVL}$, com capacidade nominal de $1500 \mathrm{kN}$. Estes elementos foram caracterizados a partir de um controle de deslocamentos com velocidade de 0,02 $\mathrm{mm} / \mathrm{s}$, e foram instrumentados com quatro transdutores de deslocamentos, conforme a Figura 5.13 (a).

Figura 5.13 - Ensaio de resistência à compressão em (a) prisma e (b) pequenas paredes após situação de incêndio

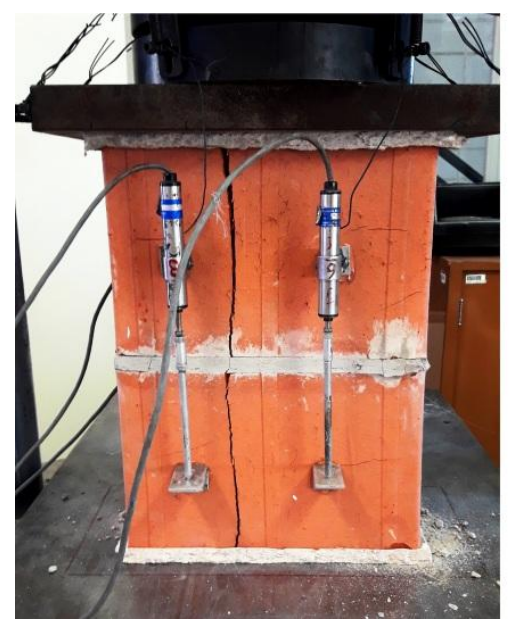

(a)

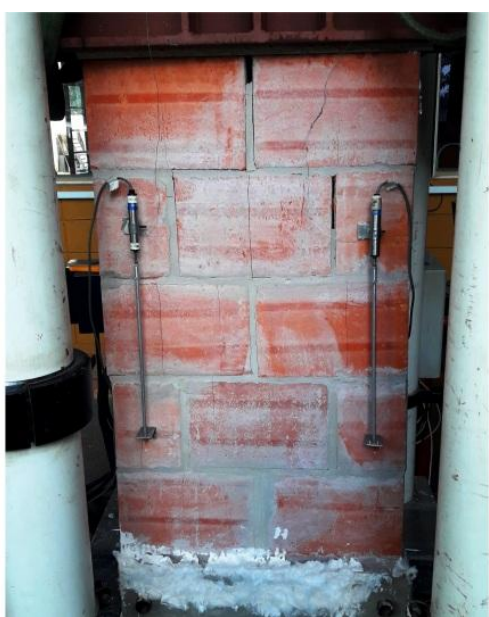

(b)

Fonte: Autor (2020). 
Nos prismas, a utilização dos transdutores de deslocamentos com base igual a $20 \mathrm{~cm}$ simétricos em ambas as faces longitudinais dos elementos, possibilitou a obtenção dos diagramas tensão x deformação ilustrados na Figura para todos os corpos de prova de ambas as geometrias.

Figura 5.14 - Diagramas tensão x deformação dos prismas com blocos de paredes (a) vazadas e (b) maciças após situação de incêndio

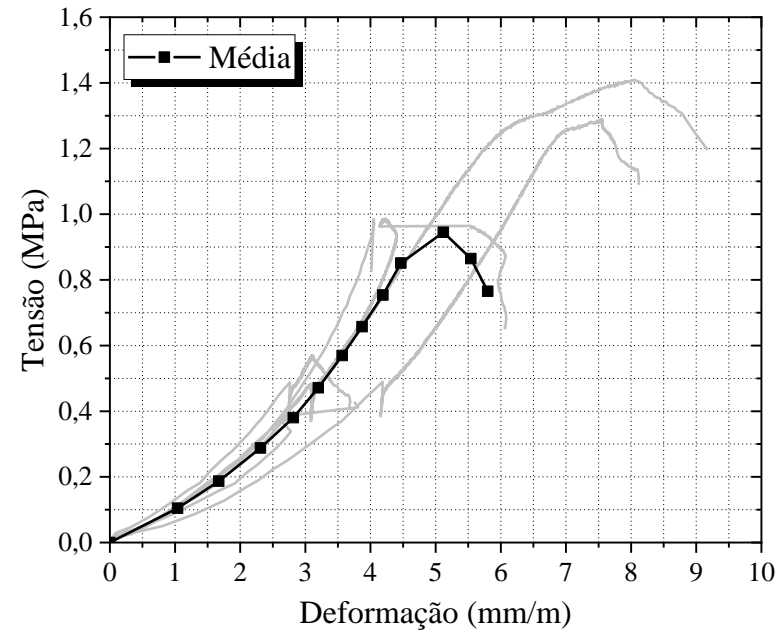

(a)

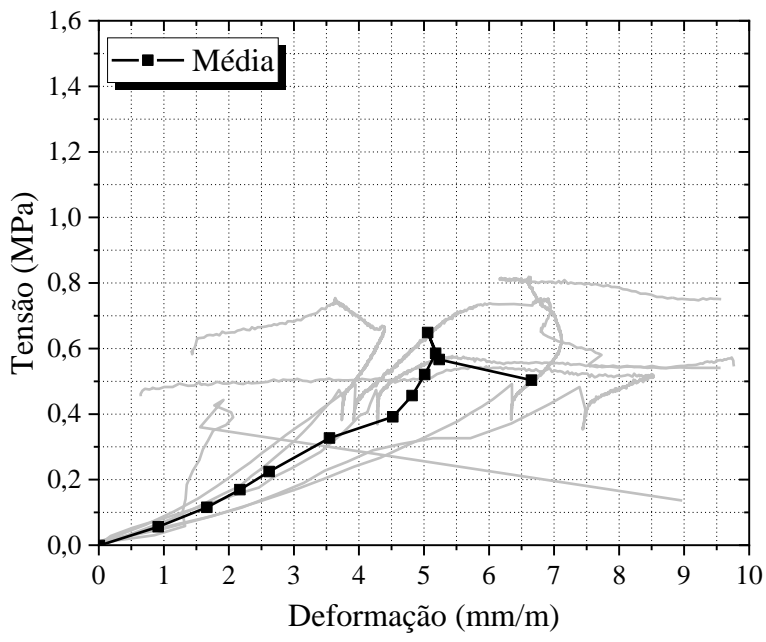

(b)

Fonte: Autor (2020).

Para obtenção do módulo de elasticidade dos prismas, utilizaram-se as prescrições normativas do ACI 530-05:2005 que recomenda uma análise baseada no módulo secante obtido no trecho dos diagramas entre $5 \%$ e $33 \%$ da tensão de ruptura. A Tabela 5.3 apresenta os valores médios e característicos da caracterização mecânica dos prismas.

Tabela 5.3 - Resistência à compressão e módulo de elasticidade dos prismas após situação de incêndio

\begin{tabular}{cccccc}
\hline \hline & $\begin{array}{c}\text { Força } \\
(\mathbf{k N})\end{array}$ & $\begin{array}{c}\text { Resistência na } \\
\boldsymbol{A}_{\text {bruta }}(\mathbf{M P a})\end{array}$ & $\begin{array}{c}\text { Resistência na } \\
\boldsymbol{A}_{\text {liq }}(\mathbf{M P a})\end{array}$ & $\begin{array}{c}\mathbf{E} \text { na } \boldsymbol{A}_{\text {bruta }} \\
(\mathbf{G P a})\end{array}$ & $\begin{array}{c}\mathbf{E} \text { na } \boldsymbol{A}_{\text {liq }} \\
(\mathbf{G P a})\end{array}$ \\
\hline \hline Média & 38,44 & \multicolumn{6}{c}{ Prismas cerâmicos com blocos de paredes vazadas } \\
DP & 15,69 & 0,94 & 2,56 & 0,13 & 0,35 \\
$\mathbf{C V}(\boldsymbol{\%})$ & 40,83 & 40,83 & 1,06 & 0,03 & 0,08 \\
$\mathbf{f}_{\mathbf{p k}}$ & - & 0,38 & 40,83 & 20,89 & 20,89 \\
\hline \hline & \multicolumn{7}{c}{ Prismas cerâmicos com blocos de paredes maciças } \\
\hline Média & 26,39 & 0,64 & 1,31 & - \\
DP & 6,00 & 0,15 & 0,31 & 0,09 & 0,18 \\
CV $(\boldsymbol{\%})$ & 22,74 & 22,74 & 22,74 & 0,03 & 0,06 \\
$\mathbf{f}_{\mathbf{p k}}$ & - & 0,41 & 0,84 & 31,83 & - \\
\hline \hline
\end{tabular}

Fonte: Autor (2020). 
Os ensaios mecânicos das pequenas paredes ocorreram em uma máquina Instron universal, modelo 8506, com capacidade de carga para $2500 \mathrm{kN}$. Conforme comentado anteriormente, a alta danificação apresentada pelas pequenas paredes isoladas impossibilitou a realização de testes mecânicos nas mesmas, resultando em uma avaliação apenas das pequenas paredes compartimentadas. Por sua vez, estas foram instrumentadas com quatro transdutores de deslocamento com base igual a $40 \mathrm{~cm}$ ao longo das suas faces longitudinais, como ilustrado na Figura 5.13.

As Figuras 5.15 e 5.16 apresentam os diagramas tensão $\mathrm{x}$ deformação para as pequenas paredes compartimentadas com e sem revestimento, respectivamente.

Figura 5.15 - Diagramas tensão x deformação das pequenas paredes compartimentadas com blocos de paredes (a) vazadas e (b) maciças após situação de incêndio

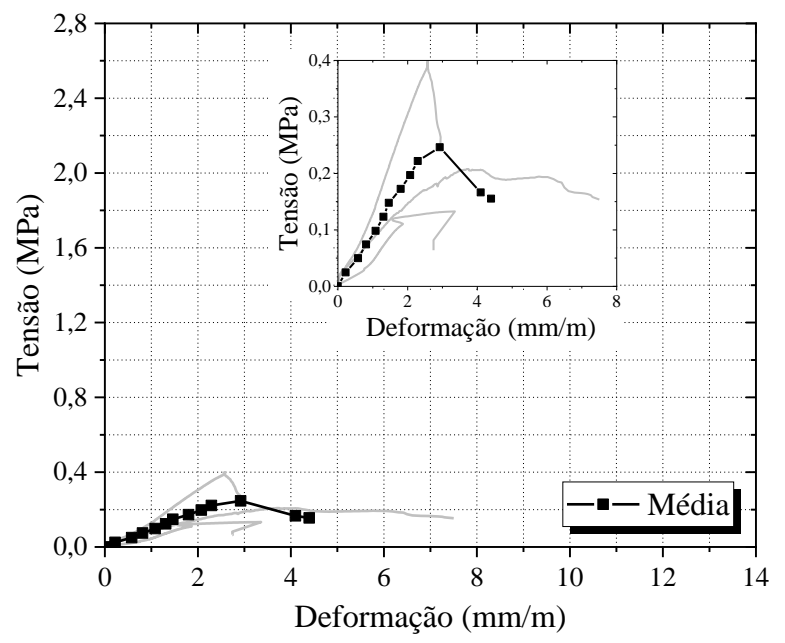

(a)

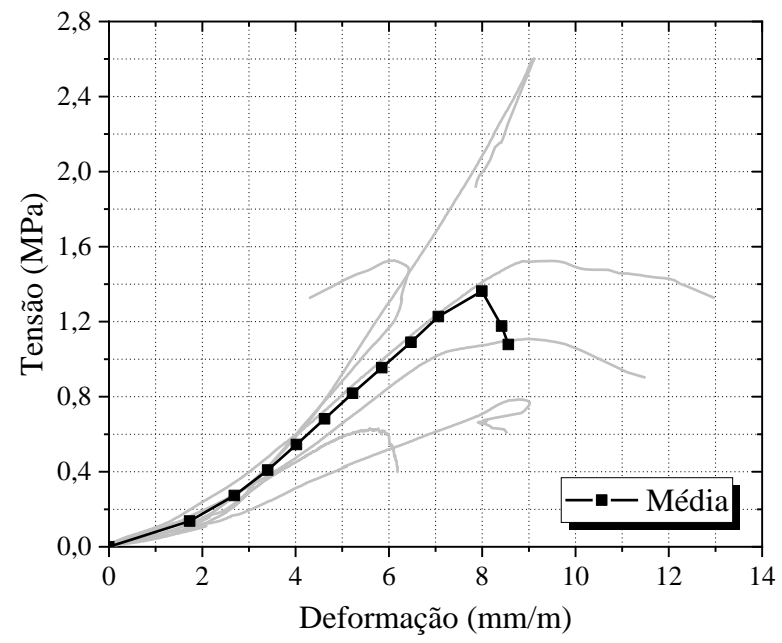

(b)

Fonte: Autor (2020).

Figura 5.16 - Diagramas tensão x deformação das pequenas paredes compartimentadas revestidas com argamassa de (a) cimento e (b) gesso 1:2 após situação de incêndio

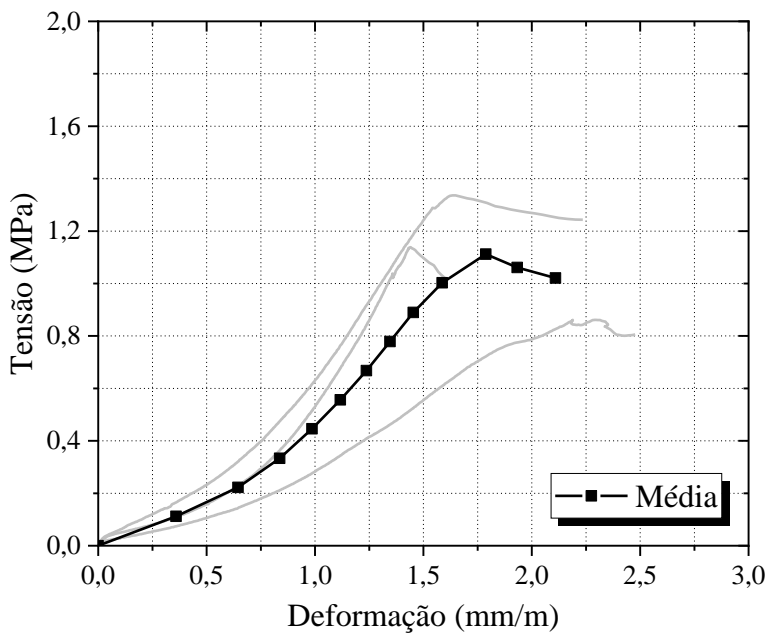

(a)

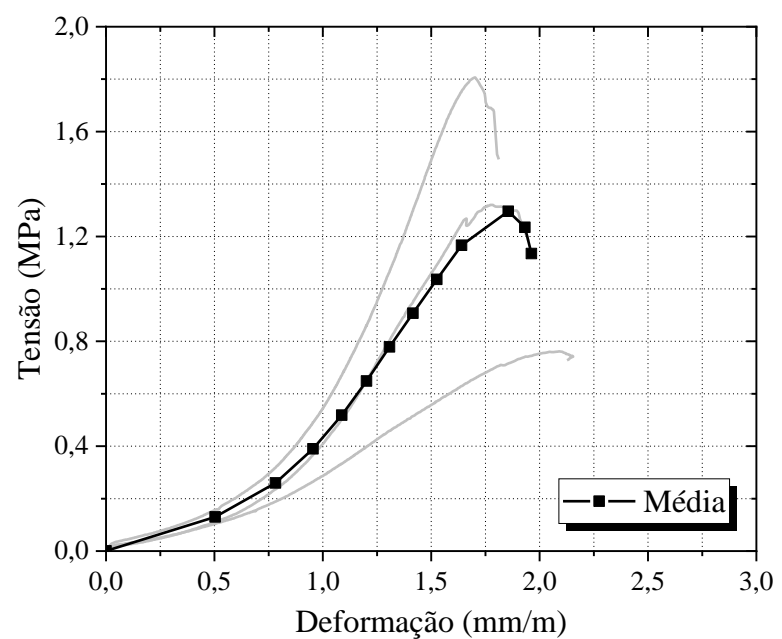

(b)

Fonte: Autor (2020). 
A obtenção do módulo de elasticidade das pequenas paredes foi feita analisando-se o trecho inicial contido entre $5 \%$ e $33 \%$ dos diagramas tensão x deformação dos elementos, conforme recomendado pelo ACI 530-05:2005. Na Tabela 5.4 foram descritos os resultados médios e característicos para as quatro séries de pequenas paredes compartimentadas deste trabalho.

Tabela 5.4 - Resistência à compressão e módulo de elasticidade das pequenas paredes compartimentadas após situação de incêndio

\begin{tabular}{|c|c|c|c|c|c|}
\hline & $\begin{array}{c}\text { Força } \\
(\mathbf{k N})\end{array}$ & $\begin{array}{c}\text { Resistência na } \\
A_{\text {bruta }}(\mathrm{MPa}) \\
\end{array}$ & $\begin{array}{c}\text { Resistência na } \\
A_{\text {liq }}(\mathrm{MPa}) \\
\end{array}$ & $\begin{array}{c}\text { E na } A_{\text {bruta }} \\
(\mathbf{G P a})\end{array}$ & $\begin{array}{c}\mathbf{E} \text { na } A_{\text {liq }} \\
(\mathbf{G P a}) \\
\end{array}$ \\
\hline \multicolumn{6}{|c|}{ Com blocos de paredes vazadas sem revestimento } \\
\hline Média & 20,39 & 0,25 & 0,66 & 0,08 & 0,21 \\
\hline DP & 11,34 & 0,14 & 0,37 & 0,04 & 0,11 \\
\hline $\mathrm{CV}(\%)$ & 55,64 & 55,64 & 55,64 & 49,04 & 49,04 \\
\hline $\mathbf{f}_{\mathrm{ppk}}$ & - & 0,11 & 0,29 & - & - \\
\hline \multicolumn{6}{|c|}{ Com blocos de paredes maciças sem revestimento } \\
\hline Média & 114,45 & 1,36 & 2,73 & 0,14 & 0,28 \\
\hline DP & 59,70 & 0,71 & 1,43 & 0,06 & 0,12 \\
\hline $\mathrm{CV}(\%)$ & 52,16 & 52,16 & 52,16 & 43,70 & 43,70 \\
\hline $\mathbf{f}_{\mathrm{ppk}}$ & - & 0,56 & 1,13 & - & - \\
\hline \multicolumn{6}{|c|}{ Com blocos de paredes vazadas revestidas com argamassa de cimento } \\
\hline Média & 92,06 & 1,11 & 2,94 & 0,45 & 1,19 \\
\hline DP & 19,74 & 0,24 & 0,63 & 0,11 & 0,29 \\
\hline $\mathrm{CV}(\%)$ & 21,44 & 21,44 & 21,44 & 24,07 & 24,07 \\
\hline $\mathbf{f}_{\mathrm{ppk}}$ & - & 0,69 & 1,82 & - & - \\
\hline \multicolumn{6}{|c|}{ Com blocos de paredes vazadas revestidas com argamassa de gesso 1:2 } \\
\hline Média & 107,28 & 1,30 & 3,44 & 0,50 & 1,32 \\
\hline DP & 43,28 & 0,52 & 1,37 & 0,20 & 0,53 \\
\hline $\mathrm{CV}(\%)$ & 40,34 & 40,34 & 40,34 & 41,37 & 41,37 \\
\hline $\mathbf{f}_{\mathrm{ppk}}$ & - & 0,61 & 1,61 & - & - \\
\hline
\end{tabular}

Fonte: Autor (2020).

De modo geral, as propriedades mecânicas dos elementos estruturais de alvenaria foram muito influenciadas pela deformabilidade excessiva da argamassa de assentamento e pela distribuição das fissuras oriundas das deformações térmicas diferenciais que ocorreram durante os ensaios de simulação de incêndio-padrão.

Dessa maneira, verificou-se que a ruptura dos prismas ocorreu principalmente devido ao esmagamento da junta de argamassa, ou pela instabilidade de regiões críticas nos 
elementos devido à presença de grandes aberturas de fissuras que surgiram durante os ensaios de incêndio-padrão, conforme apresentado na Figura 5.17.

Figura 5.17 - Modo de ruptura dos prismas após situação de incêndio
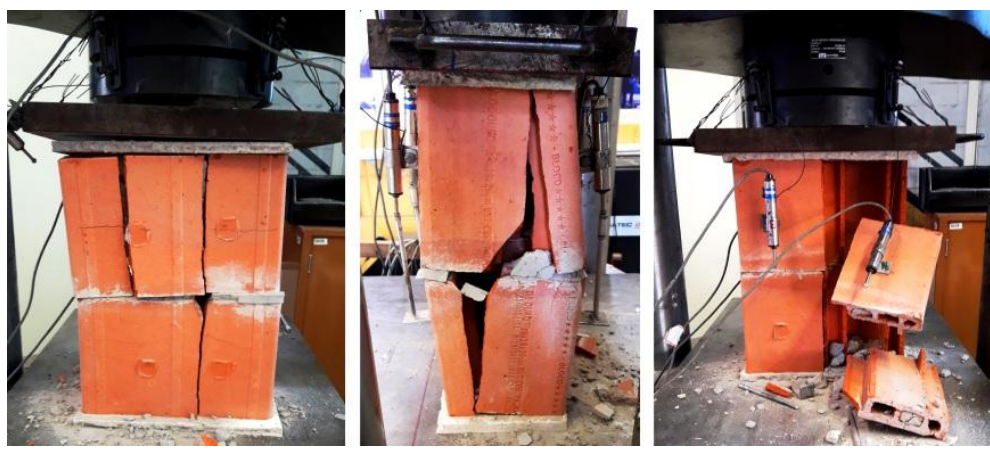

Fonte: Autor (2020).

Nas pequenas paredes compartimentadas, além do esmagamento das juntas de argamassa nas últimas fiadas dos elementos, observou-se que foi governada principalmente pelo surgimento de fissuras verticais ao longo das faces laterais dos corpos de prova, como pode ser visto na Figura 5.18.

Figura 5.18 - Modo de ruptura das pequenas paredes compartimentadas após situação de incêndio

Fonte: Autor (2020).
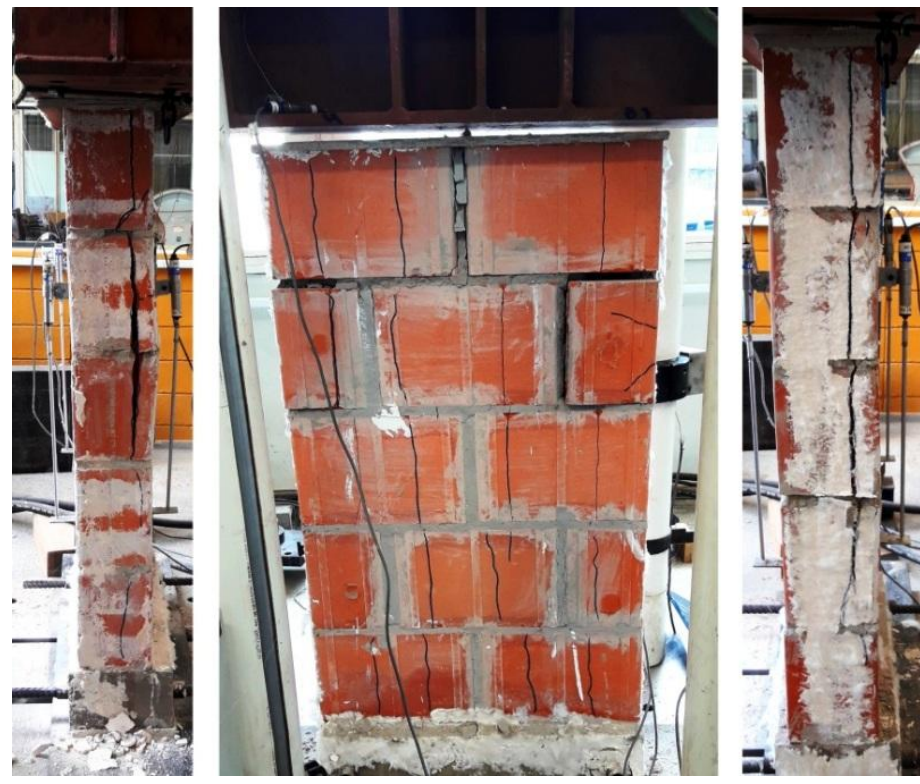

Apesar da existência prévia das fissuras nas faces laterais devidas às deformações diferenciais provocadas pela elevação de temperatura, as pequenas paredes compartimentadas apresentaram uma curvatura ao longo da altura do elemento, favorecendo a manifestação de esforços de flexão durante os ensaios, associada à excentricidade verificada, o que pode ter favorecido o aumento das tensões de tração nas faces laterais e contribuído para a ruína do elemento estrutural. A curvatura apresentada pelas pequenas paredes ocorreu devido à 
expansão térmica diferencial em ambas as faces e foi mais significativa nos elementos revestidos, em razão do maior gradiente térmico (Figura 5.19), sendo anteriormente observada nos trabalhos de Nadjai et al. (2006), Carvalho (2019) e Dupim (2019).

Figura 5.19 - Curvatura apresentada pelas pequenas paredes compartimentadas revestidas com argamassas de (a) cimento e (b) gesso 1:2

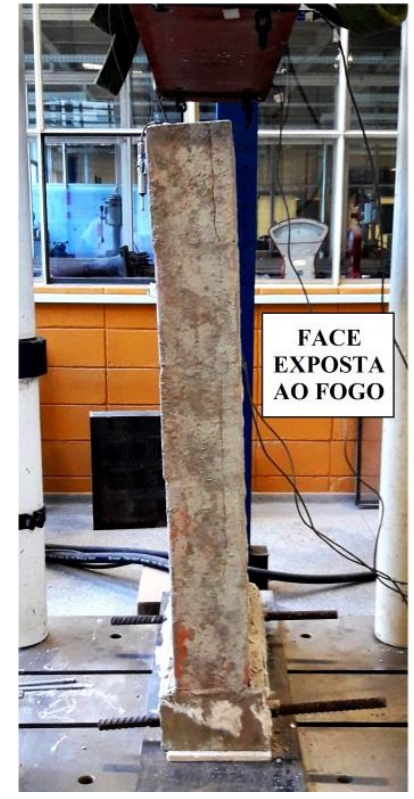

(a)

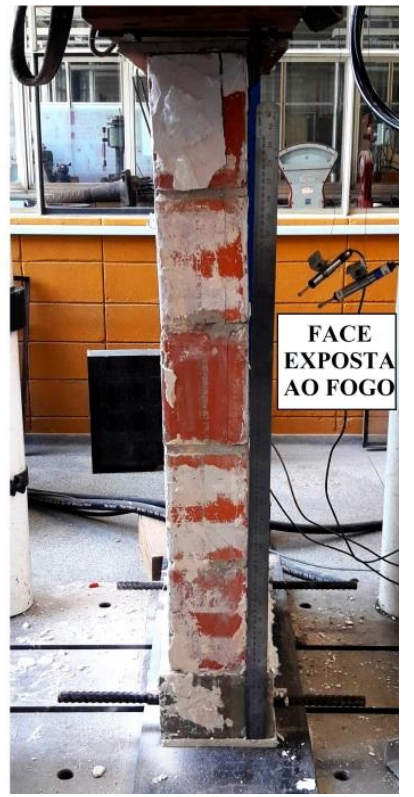

(b)

Fonte: Autor (2020).

Através dos transdutores de deslocamento instalados em cada face dos elementos durante os ensaios, observou-se que a expansão térmica diferencial e a menor degradação do elemento na face não exposta ao fogo promoveram reduções de $72 \%$ e $66 \%$ das deformações específicas dos elementos revestidos, conforme apresentado na Figura 5.20.

Figura 5.20 - Diagramas tensão x deformação conforme face de atuação do fogo nas pequenas paredes compartimentadas revestidas com argamassa de (a) cimento e (b) gesso

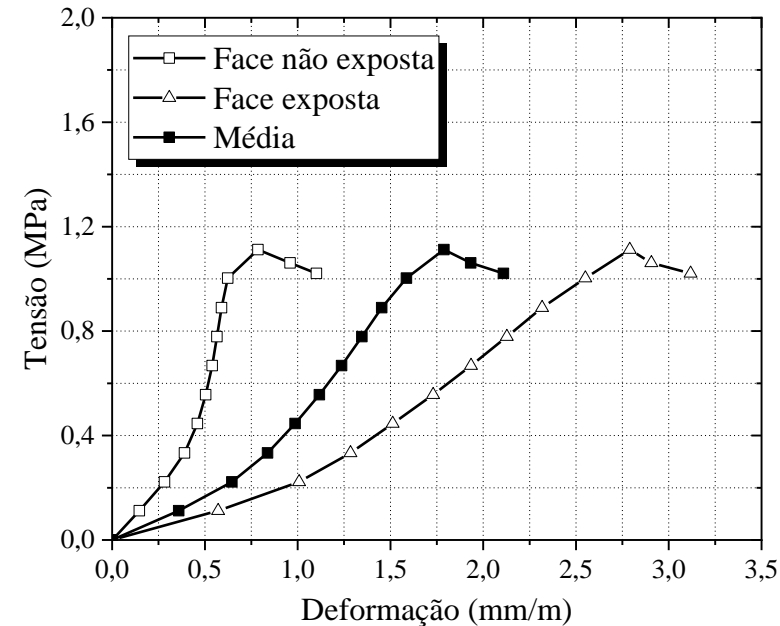

(a)

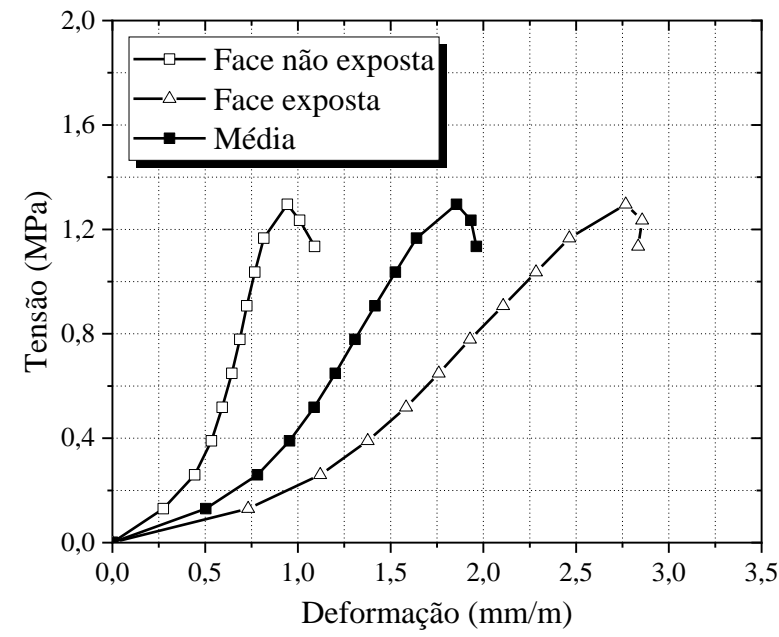

(b)

Fonte: Autor (2020) 


\subsection{REIDRATAÇÃO DA ARGAMASSA DE ASSENTAMENTO}

De maneira geral, os materiais cimentícios sofrem grande danificação quando expostos a elevadas temperaturas e apresentam brusca redução nas propriedades mecânicas. Mehta e Monteiro (2014) atribuem este comportamento a fatores relacionados às modificações na microestrutura dos materiais, inicialmente com a perda da água interlamelar dos silicatos de cálcio hidratados (C-S-H) e dos sulfoaluminatos hidratados, com posterior desidratação da pasta de cimento devido à decomposição do hidróxido de cálcio $\left(\mathrm{Ca}(\mathrm{OH})_{2}\right)$, seguida pela decomposição total do C-S-H em temperaturas próximas a $900{ }^{\circ} \mathrm{C}$. Como as simulações de incêndio-padrão atingiram temperaturas da ordem de $1050{ }^{\circ} \mathrm{C}$, esse comportamento também foi verificado nas argamassas de assentamento, como ilustrado na Figura 5.21.

Figura 5.21 - Micrografias da argamassa de assentamento a (a) temperatura ambiente e (b) após situação de incêndio
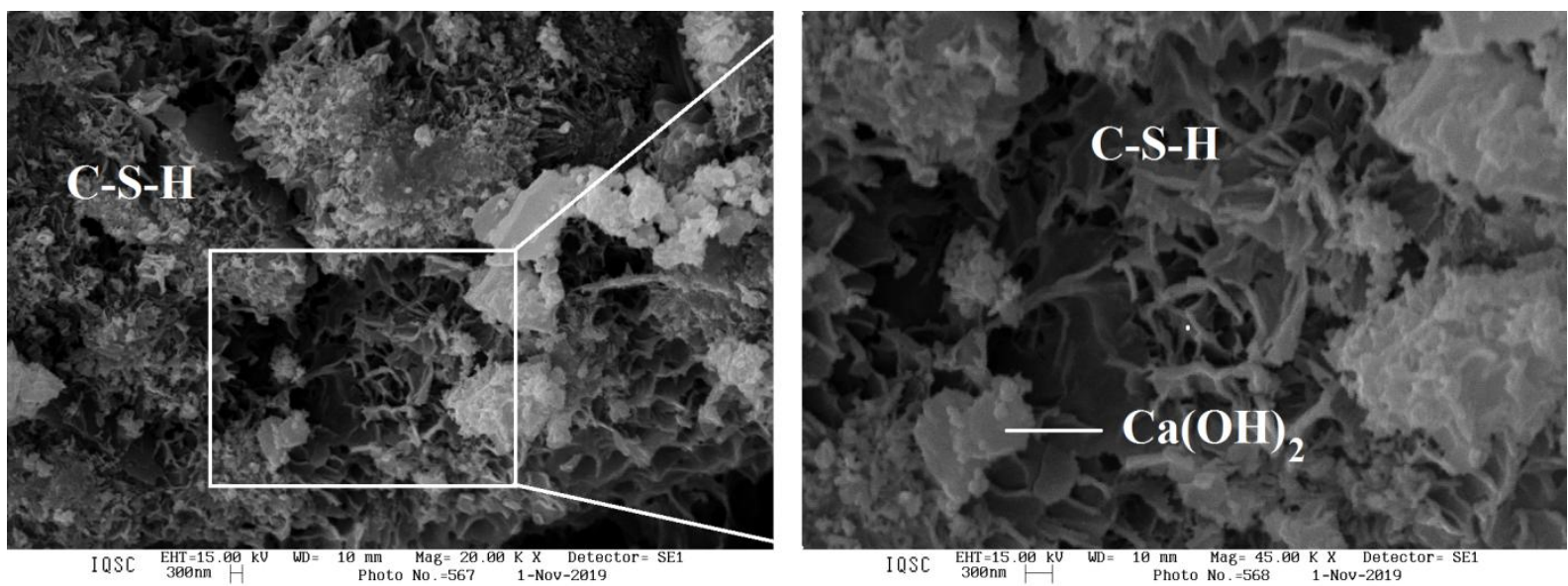

(a)
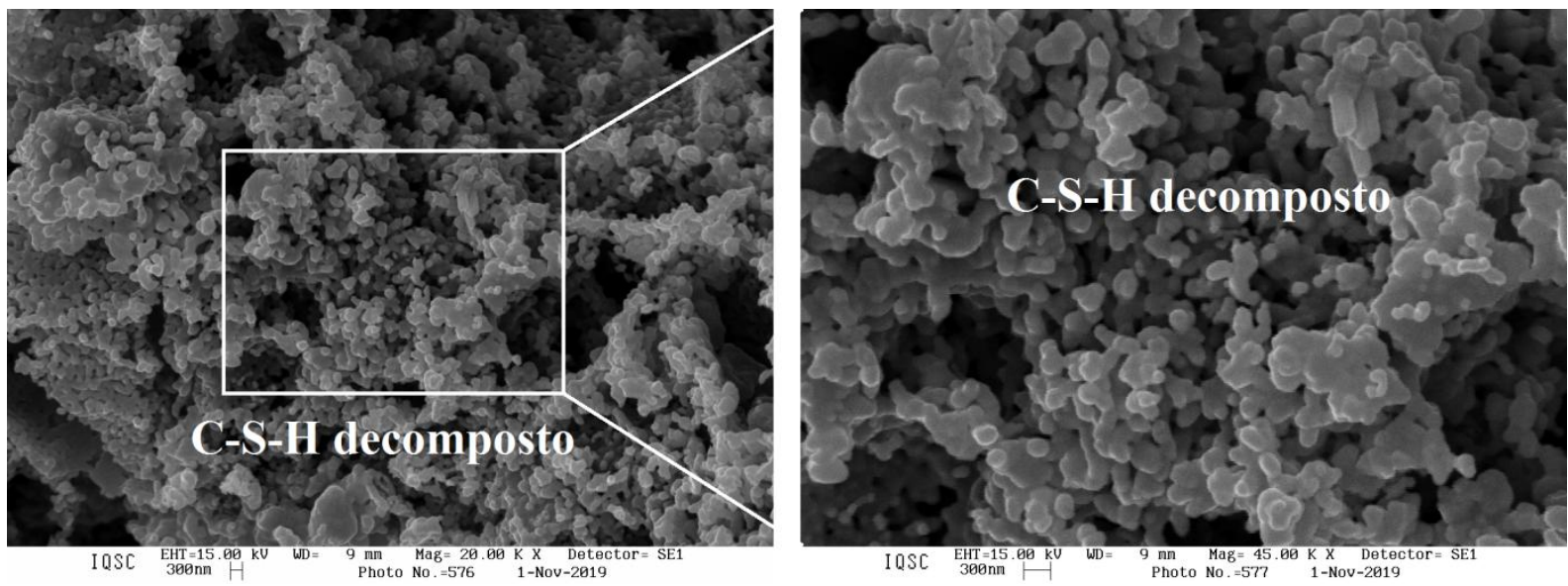

(b)

Fonte: Autor (2020).

Neste trabalho, os ensaios mecânicos nas argamassas de assentamento foram 
realizados em três diferentes idades após as mesmas submeterem-se à situação de incêndio, possibilitando uma avaliação quanto à influência do fenômeno da reidratação no comportamento mecânico desses componentes.

Conforme apresentado no item 5.3.1, as argamassas avaliadas 3 e 7 dias após a simulações de incêndio sofreram uma redução na resistência à compressão de 27,2\% e 48,1\%, respectivamente, em relação a aquelas ensaiadas 1 dia após a elevação de temperatura. Este comportamento deve-se à reidratação do óxido de cálcio $(\mathrm{CaO})$ gerado a partir da desidratação do hidróxido de cálcio $\left(\mathrm{Ca}(\mathrm{OH})_{2}\right)$ durante a elevação de temperatura. Quando exposto, o óxido de cálcio inicia o processo de reidratação devido à absorção da umidade ambiente, produzindo o hidróxido de cálcio novamente, que pode apresentar um volume até $44 \%$ superior que o óxido, ocasionando a desintegração do material e formação de fissuras, segundo Acka e Ozyurt (2018).

Além disso, Hendry (2011) comenta que a exposição do óxido de cálcio também favorece reações químicas com o dióxido de carbono $\left(\mathrm{CO}_{2}\right)$ disponível no ambiente, produzindo o carbonato de cálcio $\left(\mathrm{CaCO}_{3}\right)$ que incentiva o fenômeno de carbonatação no material, prejudicando sua resistência mecânica, conforme mostra a Figura 5.22.

Figura 5.22 - Produção de carbonato de cálcio em argamassa de assentamento

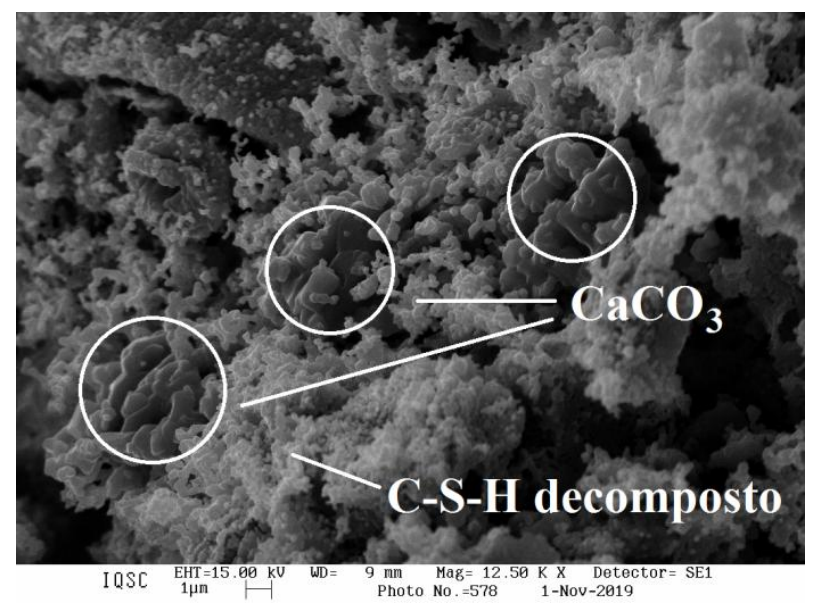

Fonte: Autor (2020).

Durante a realização dos ensaios, observou-se uma alteração significativa no aspecto superficial dos corpos de prova conforme a idade de ensaio, como segue ilustrado na Figura 5.23. Quanto à situação destas nos elementos de alvenaria, observaram-se menores índices de degradação devido ao confinamento oferecido pelas unidades cerâmicas e menor exposição da junta às condições do ambiente, em relação aos corpos de prova isolados. Ademais, apesar da influência moderada da resistência da argamassa de assentamento na resistência da alvenaria, a alta deformabilidade do material pode influenciar no comportamento mecânico dos 
elementos de alvenaria e, portanto, carecem de estudos posteriores.

Figura 5.23 - Aspecto superficial das argamassas de assentamento sob (a) temperatura ambiente, (b) 1 dia, (c) 3 dias e (d) 7 dias após situação de incêndio

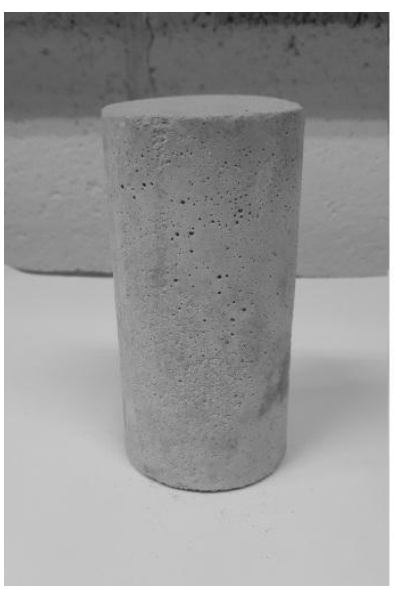

(a)

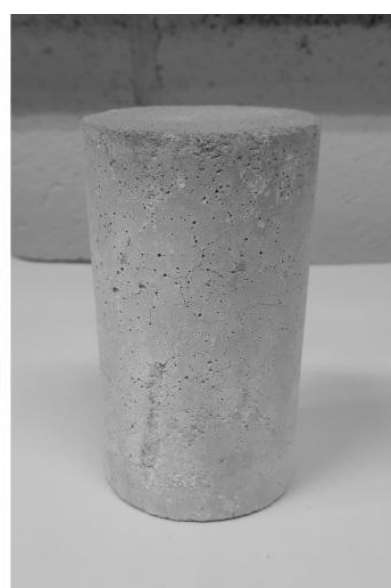

(b)

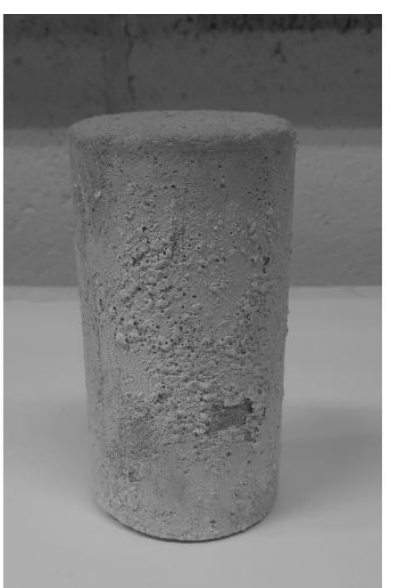

(c)

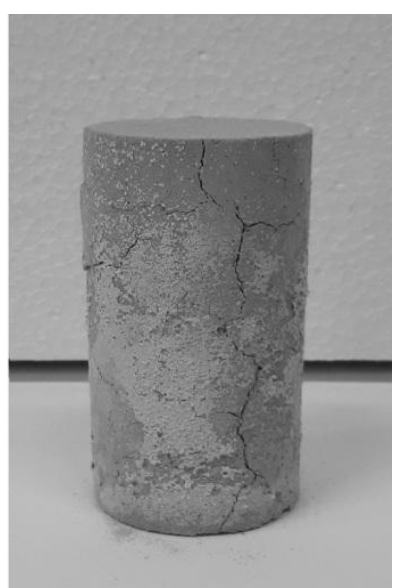

(d)

Fonte: Autor (2020).

Mediante análise da Figura 5.24, devido aos baixos valores de resistência à compressão obtidos, realizaram-se os testes estatísticos $\mathrm{F}$ e $\mathrm{T}$ para avaliar a hipótese de igualdade entre todas as amostras, para um nível de significância de 95\%, verificando que ambas as amostras são significativamente diferentes entre si. A descrição detalhada dos testes estatísticos foi realizada no Apêndice B.

Figura 5.24 - Variação dos diagramas tensão x deformação das argamassas de assentamento conforme idade após situação de incêndio

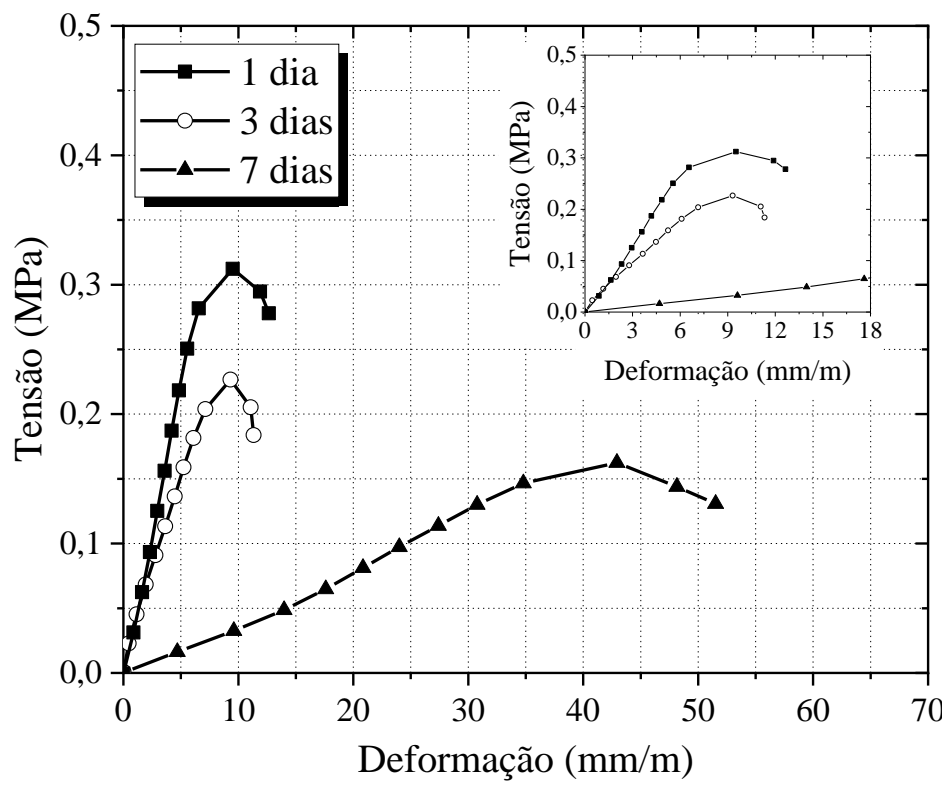

Fonte: Autor (2020).

A Tabela 5.5 apresenta a resistência residual da argamassa de assentamento após a situação de incêndio, conforme a idade de ensaio, observando-se que ela apresentou variação 
de $3,7 \%$ a 7,1\%, destacando-se ainda a alta deformabilidade das argamassas após 7 dias dos ensaios de incêndio-padrão, que apresentaram uma deformação de pico até 20,6 e 4,5 vezes superior em relação às mesmas sob temperatura ambiente e ensaiadas 1 dia após a exposição a elevadas temperaturas, respectivamente.

Tabela 5.5 - Resistência à compressão residual da argamassa de assentamento

\begin{tabular}{cccc}
\hline & $\begin{array}{c}\text { 1 dia após } \\
\text { incêndio-padrão }\end{array}$ & $\begin{array}{c}\text { 3 dias após incêndio- } \\
\text { padrão }\end{array}$ & $\begin{array}{c}\mathbf{7} \text { dias após } \\
\text { incêndio-padrão }\end{array}$ \\
\hline Argamassa & $7,1 \%$ & $5,2 \%$ & $3,7 \%$ \\
\hline
\end{tabular}

Fonte: Autor (2020).

\subsection{PROPRIEDADES RESIDUAIS DOS ELEMENTOS DE ALVENARIA}

A elevada resistência mecânica residual verificada nas unidades cerâmicas no item 5.3.2 deve-se principalmente ao processo de sinterização do material. Para Silva e Alves Jr. (1998), esta é uma das principais etapas no processamento tecnológico de materiais metálicos e cerâmicos a partir dos pós dos constituintes. Nesta etapa ocorre a conformação dos produtos gerados sob ação do calor e definição das propriedades finais, por exemplo, com aquisição de resistência mecânica, retração das peças e diminuição da porosidade.

As unidades cerâmicas submeteram-se ao processo de sinterização durante a fabricação, onde a mistura de argila extrudada foi encaminhada para queima sob temperatura aproximada de $850^{\circ} \mathrm{C}$. Dessa maneira, a submissão dos blocos cerâmicos à situação de incêndio favorece o desenvolvimento das propriedades do material, conforme a Figura 5.25, tendo em vista uma nova ação de temperaturas superiores às do processo inicial de fabricação.

Figura 5.25 - Micrografias do material cerâmico (a) antes e (b) após a situação de incêndio

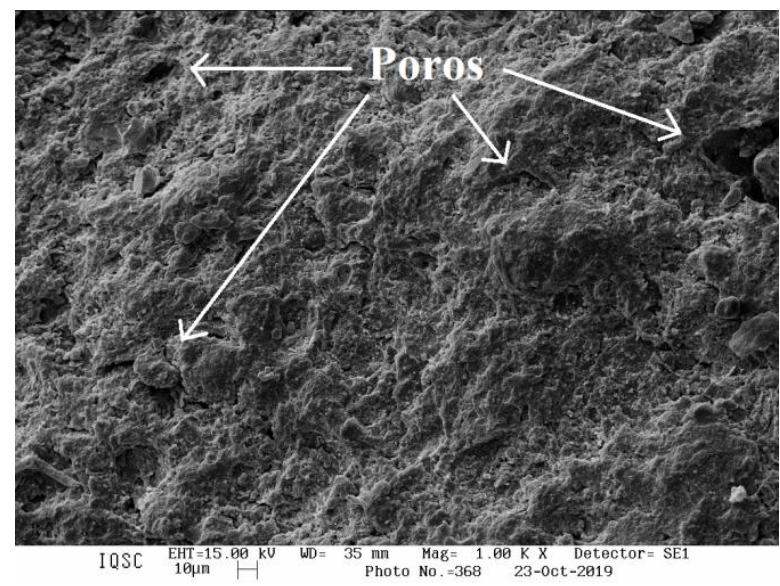

(a)

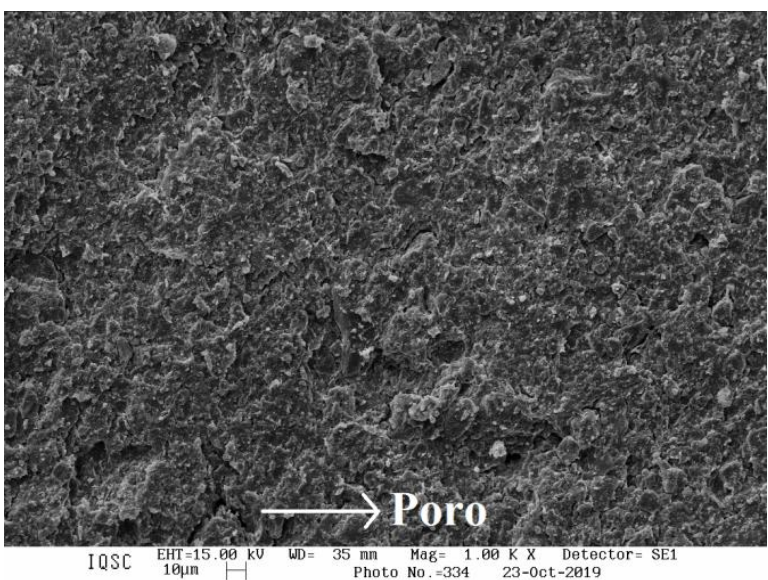

(b)

Fonte: Autor (2020) 
Outros autores como Marvila et al. (2019), Azevedo et al. (2018) e Gonçalves et al. (2016) também verificaram uma melhoria nas propriedades mecânicas e redução da porosidade em unidades cerâmicas conforme aumento da temperatura de fabricação. Silva e Alves Jr. (1998) atribuem esses fatores às diferentes reações das matérias-prismas e a maior densificação que pode ocorrer devido ao transporte interno de material de diferentes formas, como por fluxo viscoso, difusão atômica ou ainda pela formação de um líquido resultante da reação entre dois ou mais componentes, como mostra a Figura 5.26.

Figura 5.26 - Densificação do material cerâmico (a) antes e (b) após a situação de incêndio

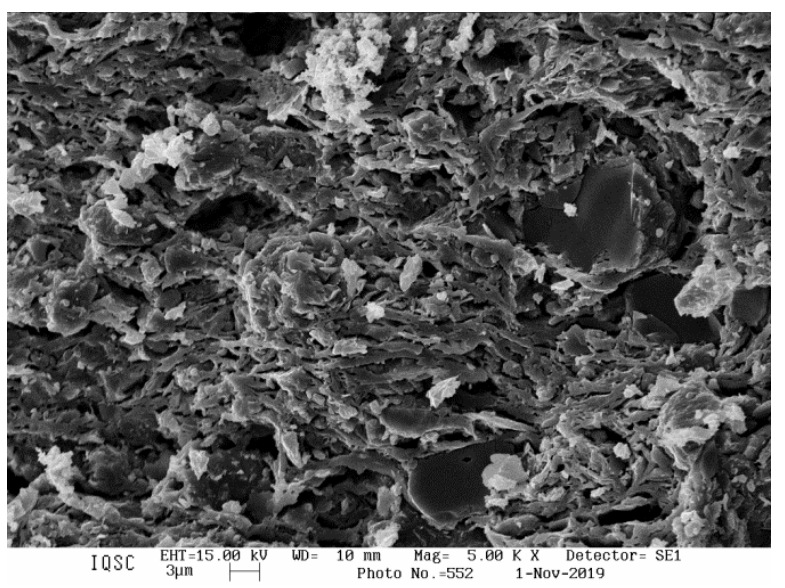

(a)

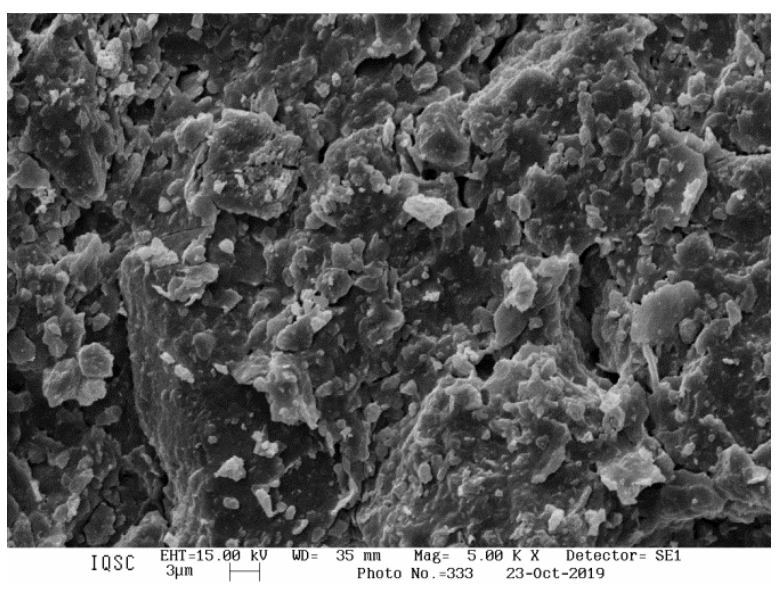

(b)

Fonte: Autor (2020).

Para verificar a alteração da porosidade, após as simulações de incêndio-padrão, realizaram-se novos ensaios de absorção nos blocos cerâmicos conforme aqueles descritos em 3.2.2, e constatou-se uma redução discreta nesta propriedade em ambos os tipos de unidades analisadas neste trabalho, conforme apresentado na Figura 5.27.

Figura 5.27 - Variação da absorção dos blocos cerâmicos após a situação de incêndio

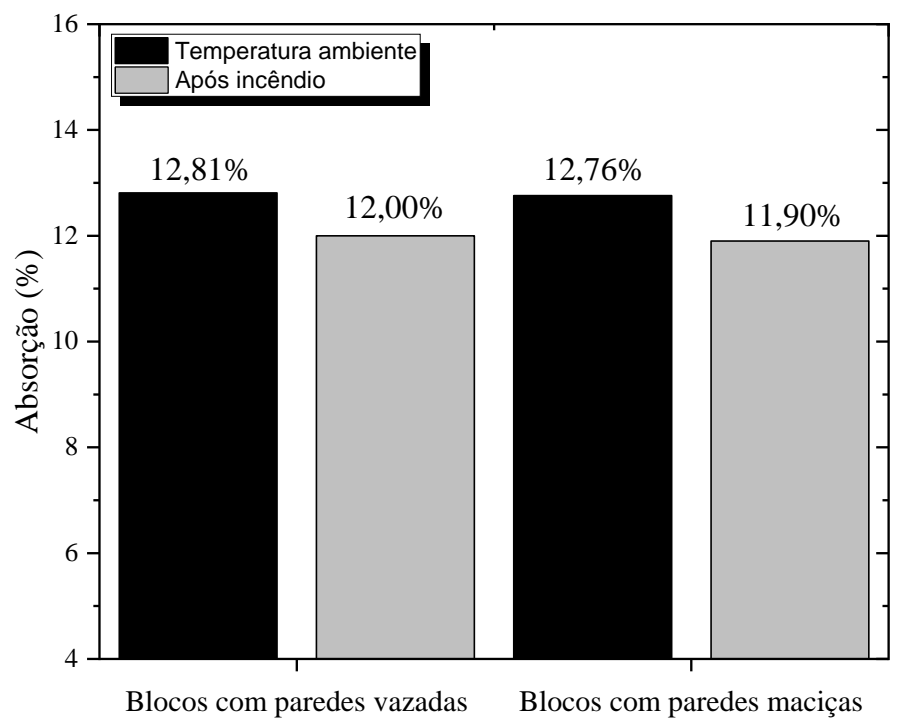

Fonte: Autor (2020). 
Apesar da redução da absorção média em 6,3\% e 6,7\% para os blocos com paredes vazadas e maciças, respectivamente, os testes estatísticos $\mathrm{F}$ e $\mathrm{T}$ não apontaram diferenças significativas entre as duas situações para um nível de significância de 95\%. O mesmo ocorreu entre as amostras de resistência à compressão dos blocos cerâmicos.

Através da técnica de difração de Raio-X, realizaram-se análises para obtenção das fases mineralógicas do material cerâmico e identificação dos minerais argilosos dos dois tipos de unidades em ambas as situações abordadas neste trabalho. As análises foram realizadas em um difratômetro de Raio-X, Brucker, modelo D2, disponível na Central de Análises Químicas do Instituto de Química de São Carlos (CAQI - IQSC). O material cerâmico por sua vez apresentou características mineralógicas compostas basicamente pelo quartzo, com baixos picos de presença de Hematita e Espinélio, por exemplo, conforme apresentado na Figura 5.28 .

Figura 5.28 - Difração de Raio-X para o material cerâmico dos blocos com paredes (a) vazadas e (b) maciças

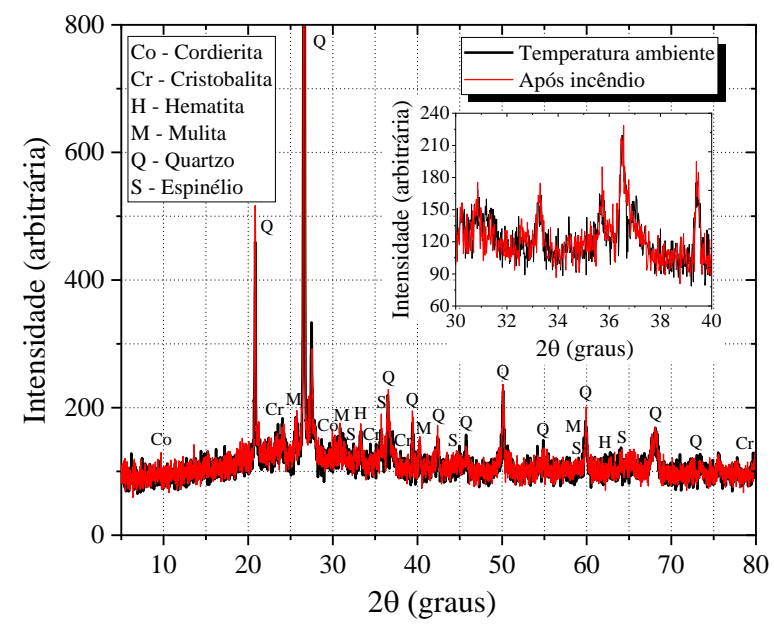

(a)

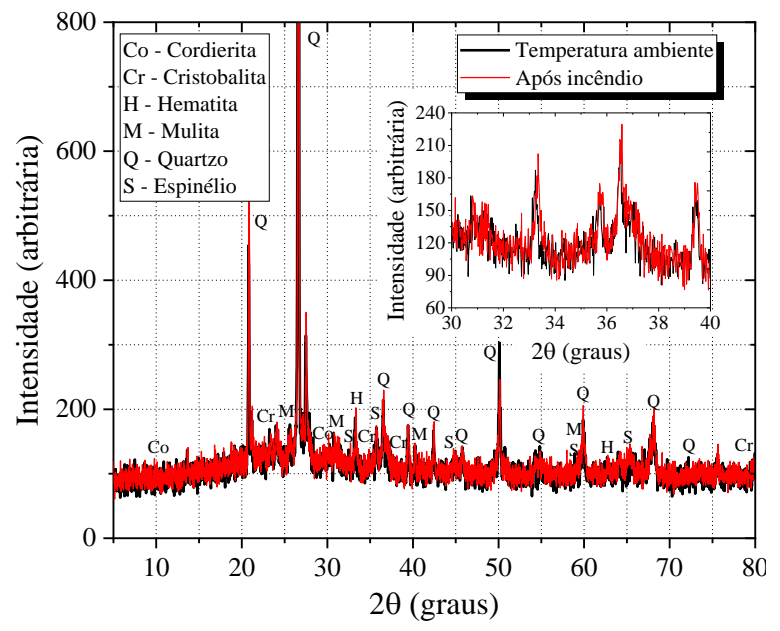

(b)

Fonte: Autor (2020).

A elevação de temperatura nestes materiais pode ocasionar a presença ou decomposição de novas fases, no entanto, não foram observadas alterações significativas na composição do material após o mesmo submeter-se à situação de incêndio. Nesse contexto, Mandic et al. (2016) declara que a Mulita, por exemplo, oferece grande importância para as cerâmicas tradicionais, proporcionando boa resistência elétrica e mecânica, baixa expansão térmica e boa estabilidade térmica, no entanto, sua formação ocorre apenas em temperaturas acima de $1250^{\circ} \mathrm{C}$, portanto, não sendo alcançadas neste trabalho.

De modo geral, as modificações no material cerâmico foram constatadas de maneira qualitativa através das imagens microscópicas, e observou-se que a elevação de temperatura 
através das simulações de incêndio-padrão induziu comportamentos diferentes nas unidades de alvenaria. Visto que, o aumento de temperatura promoveu benefícios na resistência mecânica e porosidade do material, porém, a maneira brusca e rápida pela qual a elevação de temperatura sucedeu, favoreceu o surgimento de fissuras expressivas ao longo das dimensões dos corpos de prova, podendo ter reduzido a sua capacidade resistente, estabelecendo algum equilíbrio entre as duas situações.

Finalmente, a Tabela 5.6 apresenta a resistência mecânica residual de todos os componentes e elementos de alvenaria estrutural com blocos cerâmicos avaliados nesta pesquisa.

Tabela 5.6 - Resistência média residual à compressão das unidades e elementos de alvenaria

\begin{tabular}{cccc}
\hline Elemento & $\begin{array}{c}\text { Resistência na } \boldsymbol{A}_{\text {bruta }} \text { em } \\
\text { Temp. Ambiente (MPa) }\end{array}$ & $\begin{array}{c}\text { Resistência na } \boldsymbol{A}_{\text {bruta }} \\
\text { após incêndio (MPa) }\end{array}$ & $\begin{array}{c}\text { Resistência } \\
\text { residual }\end{array}$ \\
\hline \hline Blocos & Unidades cerâmicas com blocos de paredes vazadas \\
Prismas & 10,26 & 10,34 & $100,8 \%$ \\
Pequenas paredes & 6,00 & 0,94 & $15,7 \%$ \\
$\begin{array}{c}\text { Pequenas paredes } \\
\text { rev. com cimento }\end{array}$ & 3,25 & 0,25 & $7,7 \%$ \\
$\begin{array}{c}\text { Pequenas paredes } \\
\text { rev. com gesso }\end{array}$ & 3,25 & 1,11 & $34,1 \%$ \\
\hline \hline & 3,25 & 1,30 & $40,0 \%$ \\
\hline \hline Blocos & Unidades cerâmicas com blocos de paredes maciças \\
Prismas & 11,90 & 10,90 & $91,6 \%$ \\
Pequenas paredes & 9,80 & 0,64 & $6,5 \%$ \\
\hline \hline Fonte: Autor $(2020)$. & 4,45 & 1,36 & $30,6 \%$ \\
\hline
\end{tabular}

De maneira geral, observou-se que as unidades cerâmicas permaneceram com elevada resistência mecânica, conforme discutido nos itens anteriores, porém, os elementos estruturais como os prismas e pequenas paredes sofreram alto nível de danificação do conjunto bloco/ argamassa e tiveram perdas significativas de resistência, com recuperação importante que promoveu um aumento de 4,4 e 5,2 vezes com a presença dos revestimentos em argamassas de cimento e gesso, respectivamente.

\subsection{RESUMO DO CAPÍTULO}

Neste Capítulo foram realizados os ensaios mecânicos para avaliação da resistência residual dos elementos estruturais de alvenaria. Para isso, a argamassa de assentamento, blocos, prismas e pequenas paredes de alvenaria estrutural foram avaliadas quanto à 
resistência à compressão e módulo de elasticidade. Inicialmente, foram observados níveis elevados de danificação nos corpos de prova após a realização dos ensaios de simulação de incêndio-padrão, com o desenvolvimento de fissuras significativas devido à expansão térmica diferencial sofrida pelas unidades cerâmicas.

As propriedades mecânicas da argamassa de assentamento foram avaliadas através de imagens microscópicos, que identificaram intensa decomposição do $\mathrm{C}-\mathrm{S}-\mathrm{H}$, justificando a baixa resistência residual destes componentes. Além disso, o material foi avaliado segundo três idades após a submissão do mesmo à elevação de temperatura, observando-se uma redução na resistência residual destes componentes conforme maior exposição à umidade ambiente, devido ao fenômeno de reidratação.

Estatisticamente, ambos os tipos de blocos cerâmicos estruturais não apresentaram diferenças significativas de resistência antes e após o fenômeno de incêndio. A sua resistência residual variou de $100,8 \%$ a $91,6 \%$ para os blocos com paredes vazadas e maciças, respectivamente. Este fato foi investigado de maneira peculiar, em que se verificou o desenvolvimento das propriedades mecânicas e redução da porosidade do material cerâmico devido ao processo de sinterização.

Quanto aos elementos estruturais de alvenaria que foram avaliados, prismas e pequenas paredes apresentaram elevada redução nas propriedades mecânicas após sujeitaremse à situação de incêndio. Destaca-se ainda que devido à danificação, as pequenas paredes isoladas não possibilitaram a realização dos ensaios, que por sua vez foram aplicados apenas nestes mesmos elementos compartimentados. Neste contexto, verificou-se um importante aumento da resistência residual desses elementos com a inserção de camadas de revestimento em argamassas de cimento e gesso.

Por fim, a realização de ensaios mecânicos para obtenção da resistência residual à compressão das unidades e elementos de alvenaria estrutural apresentou-se como uma etapa relevante para o entendimento do comportamento desses elementos em situação de incêndio, possibilitando análises e tomada de decisões mediante avaliação das propriedades mecânicas residuais dos mesmos. 


\section{CONCLUSÕES E OBSERVAÇÕES FINAIS}

O comportamento dos elementos de alvenaria estrutural quando submetidos à situação de incêndio foi avaliado neste trabalho através de um extenso programa experimental, em que argamassas de assentamento e revestimento, blocos, prismas e pequenas paredes foram analisados quanto aos seus comportamentos mecânico, térmico e mecânico residual.

O trabalho foi dividido em três etapas principais, pelas quais todos os componentes e elementos estruturais foram inicialmente caracterizados em temperatura ambiente quanto às respectivas propriedades geométricas, físicas e mecânicas. Em seguida foram encaminhados para as simulações de incêndio-padrão em que estiveram submetidos a uma elevação de temperatura, e por último foram verificados quanto ao comportamento mecânico residual com o objetivo de analisar as propriedades mecânicas após a submissão às condições de incêndio.

A seguir, apresentam-se as principais conclusões deste estudo, além de eventuais sugestões para pesquisas e tópicos importantes que não foram examinados nesse trabalho, mas que poderão favorecer análises experimentais e numéricas a serem realizadas posteriormente.

\subsection{CONCLUSÕES}

$\mathrm{Na}$ primeira etapa deste trabalho, as unidades de alvenaria com blocos cerâmicos foram avaliadas quanto às propriedades geométricas, físicas e mecânicas, segundo dois tipos de geometria distintos. Verificaram-se as argamassas de assentamento e revestimento mediante as propriedades físicas e mecânicas, destacando-se que as argamassas de revestimento foram caracterizadas para materiais em cimento e gesso. Por último, prismas e pequenas paredes de alvenaria estrutural confeccionados com ambos os tipos de blocos foram caracterizados mecanicamente quanto à resistência à compressão e módulo de elasticidade que, em geral, possibilitaram as seguintes conclusões:

a) Conforme variação do tipo de bloco utilizado, as unidades cerâmicas expressaram apenas pequenas diferenças quanto às suas propriedades geométricas, físicas e mecânicas, excetuando-se apenas aquelas estritamente relacionadas à geometria da unidade, como a relação $A_{\text {liq }} / A_{\text {bruta }}$;

b) Os elementos de alvenaria estrutural compostos por unidades com paredes maciças apresentaram maior resistência mecânica em relação a aqueles constituídos por unidades com paredes vazadas. A mesma tendência foi observada para a eficiência $f_{p} / f_{b}$ e $f_{p p} / f_{b}$ que variaram de 0,58 e 0,32 nas unidades com blocos 
de paredes vazadas, respectivamente, para 0,82 e 0,87 naquelas com blocos de paredes maciças;

c) Ambos os tipos de unidades cerâmicas demonstraram baixa resistência à tração indireta, com valores de 3,97\% a 5,50\% em relação à resistência à compressão na área líquida de unidades com blocos de paredes vazadas e maciças, respectivamente;

d) Os revestimentos em gesso manifestaram redução na trabalhabilidade e tempo de pega, conforme aumento do teor de agregados na composição. Nesse mesmo contexto, não foram observadas alterações significativas nas propriedades mecânicas destes materiais, com exceção da redução da resistência à flexão e aumento da resistência à aderência, mediante adição do teor de agregados e granulometria dos mesmos;

e) As unidades cerâmicas manifestaram comportamento extremamente frágil, com ruptura brusca e explosiva, enquanto que, nos elementos estruturais de alvenaria a ruptura deu-se basicamente pelo esmagamento da junta de argamassa.

$\mathrm{Na}$ segunda etapa do trabalho realizaram-se os ensaios de simulação de incêndiopadrão em argamassas, blocos, prismas e pequenas paredes. Inicialmente os elementos foram instrumentados ao longo das suas respectivas seções transversais com a instalação de cabos termopares que possibilitaram o acompanhamento da evolução de temperatura nos corpos de prova, a avaliação da compartimentação e isolamento térmico nos elementos ensaiados com a configuração compartimentada, propiciando a obtenção das seguintes conclusões:

a) O forno horizontal a gás utilizado para realizar o aquecimento dos elementos estruturais atendeu satisfatoriamente a elevação de temperatura seguindo a curva de incêndio-padrão proposta pela ISO 834-1:1999;

b) Blocos e prismas apresentaram comportamento térmico similar quando observadas as curvas de elevação de temperatura nos mesmos pontos de instrumentação. Em contrapartida, devido às maiores dimensões dos corpos de prova, número de juntas e consequentemente maior exposição à ação do fogo, as pequenas paredes desenvolveram temperaturas ligeiramente superiores;

c) Pelo mesmo fundamento, as pequenas paredes isoladas apresentaram maior evolução de temperatura em relação às pequenas paredes compartimentadas, que por sua vez possuíram apenas uma das faces longitudinais exposta à situação de incêndio; 
d) Analisando-se as pequenas paredes compartimentadas, observou-se que os elementos compostos por blocos de paredes maciças apontaram grau de compartimentação e isolamento térmico $27 \%$ superior em relação às pequenas paredes com blocos de paredes vazadas;

e) A adição das camadas de revestimento em argamassas de cimento e gesso demonstrou efetiva melhoria no comportamento térmico das pequenas paredes compartimentadas, com o critério de isolamento térmico sendo atendido para um tempo $103 \%$ e $54 \%$, respectivamente, superiores ao apresentado pelos elementos sem revestimento. No entanto, apesar da elevação do critério de isolamento térmico, todos os elementos estruturais mantiveram um tempo inferior ao TRRF de 120 minutos recomendado pela ABNT NBR 14432:2001;

f) As imagens microscópicas possibilitaram a verificação de maior porosidade nos revestimentos em argamassa de gesso, em relação à argamassa de cimento e a própria pasta de gesso. Este fato possibilitou aos elementos revestidos com argamassa de cimento o atendimento ao critério de isolamento térmico em tempo $31,3 \%$ maior do que aquele obtido pelos elementos revestidos com argamassa de gesso.

Na última etapa desta pesquisa, os corpos de prova que foram sujeitos às condições de incêndio na fase anterior, submeteram-se a ensaios mecânicos de resistência à compressão e módulo de elasticidade, possibilitando a avaliação quanto ao seu comportamento mecânico residual e aquisição de resultados como os descritos abaixo:

a) De modo geral, as unidades e os elementos de alvenaria estrutural manifestaram elevado nível de danificação quando expostos à situação de incêndio, devido principalmente às fissuras significativas no material cerâmico e à decomposição dos principais constituintes da argamassa de assentamento;

b) Observou-se que a argamassa de assentamento apresentou significativa redução na resistência à compressão e aumento da deformabilidade conforme o prolongamento da idade dos ensaios após a situação de incêndio devido ao fenômeno da reidratação, que apontou uma redução de 27,2\% e 51,9\% nos ensaios realizados 3 e 7 dias após o incêndio, respectivamente, em relação à resistência à compressão obtida 24 horas após a mesma situação;

c) Através da análise do material cerâmico dos blocos, verificou-se uma maior densificação do material e consequente redução da sua porosidade após as 
simulações de incêndio-padrão, o que possibilitou elevadas resistências residuais que variaram de 100,8\% a 91,6\% para os blocos cerâmicos com paredes vazadas e maciças, respectivamente;

d) As pequenas paredes isoladas, ou seja, que se sujeitaram a ação do fogo em todas as faces, não puderam ser ensaiadas quanto ao comportamento mecânico residual devido à grande deterioração dos corpos de prova e desagregação parcial dos componentes durante a elevação de temperatura;

e) As pequenas paredes compartimentadas, ou seja, que se sujeitaram a ação direta do fogo apenas em uma das faces longitudinais, apresentaram danificação reduzida, com os elementos compostos por blocos de paredes maciças exibindo resistência residual aproximadamente quatro vezes superior à resistência residual obtida pelos elementos com blocos de paredes vazadas;

f) A utilização dos revestimentos em argamassas de cimento e gesso favoreceu um aumento significativo na resistência residual das pequenas paredes compartimentadas, que por sua vez elevaram a resistência residual de 7,7\% obtida nos elementos sem revestimento, para $34,1 \%$ e $40 \%$ naqueles revestidos com argamassas de cimento e gesso, respectivamente. Dessa forma, essa diferença proporcionada pela incorporação dos revestimentos pode ser determinante para garantir a integridade das paredes no caso de um incêndio real.

\subsection{SUGESTÕES PARA TRABALHOS FUTUROS}

As sugestões indicadas neste item referem-se aos elementos estruturais e aos principais materiais que foram utilizados nesta pesquisa.

Quanto ao comportamento dos elementos estruturais de alvenaria em situação de incêndio, os seguintes quesitos merecem destaque:

a) Avaliação da influência das condições de contorno na danificação dos elementos de alvenaria mediante ação do incêndio, tendo em vista que nesse trabalho todos os elementos estiveram livres para se deformar;

b) Verificação do comportamento termomecânico dos elementos de alvenaria com a atuação concomitante do carregamento e da elevação de temperatura;

c) Avaliação da influência da reidratação da argamassa de assentamento no comportamento mecânico residual dos elementos, variando-se a idade de ensaio dos mesmos após a submissão à situação de incêndio. 
Quanto ao fenômeno de reidratação da argamassa de assentamento, podem ser considerados:

a) Avaliação da reidratação das argamassas com a elevação gradual em vários níveis de temperatura máxima, para identificar temperaturas críticas sobre o fenômeno;

b) Investigação da reidratação em argamassas de assentamento sem a adição da cal, reduzindo assim a quantidade de óxido de cálcio na composição da mesma;

c) Análise do fenômeno de reidratação com os materiais em outras condições de cura, como imersos em solução aquosa.

Quanto ao comportamento térmico e mecânico residual das unidades cerâmicas, algumas observações tornaram-se importantes:

a) Verificação da influência do resfriamento natural ou artificial no estado de deterioração das unidades cerâmicas sujeitas à situação de incêndio;

b) Avaliação do aumento da resistência residual em blocos cerâmicos estruturais com baixa resistência nominal $(4,0 \mathrm{MPa})$, que a princípio são produzidos em níveis inferiores de temperatura;

c) Implementação de modelo numérico computacional capaz de representar o padrão de fissuração nas unidades cerâmicas, conforme elevação de temperatura e deformações térmicas diferenciais nos corpos de prova.

Quanto ao comportamento dos revestimentos em gesso, fazem-se necessárias algumas considerações que poderão ser relevantes:

a) Avaliação das propriedades mecânicas residuais das argamassas de gesso quando submetidas à situação de incêndio;

b) Verificação da adição de aditivos retardadores de pega na composição das argamassas de gesso, tendo em vista que as utilizadas neste trabalho apresentaram baixo tempo de pega;

c) Avaliação da aderência das argamassas de gesso através de ensaios paralelos à interface revestimento/substrato, sendo esta a direção de maior solicitação devido à retração e desplacamento quando sujeitos à ação do fogo. 


\section{REFERÊNCIAS BIBLIOGRÁFICAS}

ALVES, G. P. Investigação micro e macroestrutural de argamassas submetidas a elevadas temperaturas. 2018. 141p. Dissertação (Mestrado em Engenharia de Edificações e Saneamento), Universidade Estadual de Londrina, Londrina, 2018.

ACKA, A. H.; OZYURT, N. Effects of re-curing on residual mechanical properties of concrete after temperature exposure. Construction and Building Materials, v. 159, p. 540552. 2018.

AMERICAN CONCRETE INSTITUTE. ACI-530-05: Building Code Requirements and Specification for Masonry Structures. Detroit, Michigan, 2005.

AMERICAN SOCIETY FOR TESTING AND MATERIALS. C28 - 10: Standard Specification for Gypsum Plasters. Pennsylvania, 2015.

AMERICAN SOCIETY FOR TESTING AND MATERIALS. C1006 - 07: Standard Test Method for Splitting Tensile Strength of Masonry Units. Pennsylvania, 2013.

AMERICAN SOCIETY FOR TESTING AND MATERIALS. ASTM E119: Standard Methods for Fire Test of Building Construction and Materials. Pennsylvania, 2000.

ASSOCIAÇÃO BRASILEIRA DE NORMAS TÉCNICAS. NBR 5628: Componentes construtivos estruturais - Determinação da resistência ao fogo. Rio de Janeiro, 2001.

ASSOCIAÇÃO BRASILEIRA DE NORMAS TÉCNICAS. NBR 5672: Exigências particulares das obras de concreto armado em relação à resistência ao fogo. Rio de Janeiro, 1980.

ASSOCIAÇÃO BRASILEIRA DE NORMAS TÉCNICAS. NBR 6136: Bloco vazado de concreto simples para alvenaria estrutural. Rio de Janeiro, 2016.

ASSOCIAÇÃO BRASILEIRA DE NORMAS TÉCNICAS. NBR 7215: Cimento Portland Determinação da resistência à compressão de corpos de prova cilíndricos. Rio de Janeiro, 2019.

ASSOCIAÇÃO BRASILEIRA DE NORMAS TÉCNICAS. NBR 10636: Paredes de divisórias sem função estrutural - Determinação da resistência ao fogo. Rio de Janeiro, 1989.

ASSOCIAÇÃO BRASILEIRA DE NORMAS TÉCNICAS. NBR 12129: Gesso para construção civil - Determinação das propriedades mecânicas. Rio de Janeiro, 2017.

ASSOCIAÇÃO BRASILEIRA DE NORMAS TÉCNICAS. NBR 13207: Gesso para construção civil - Requisitos. Rio de Janeiro, 2017.

ASSOCIAÇÃO BRASILEIRA DE NORMAS TÉCNICAS. NBR 13276: Argamassa para assentamento e revestimento de paredes e tetos - Determinação do índice de consistência. Rio de Janeiro, 2016. 
ASSOCIAÇÃO BRASILEIRA DE NORMAS TÉCNICAS. NBR 13279: Argamassa para assentamento e revestimento de paredes e tetos - Determinação da resistência à tração na flexão e à compressão. Rio de Janeiro, 2005.

ASSOCIAÇÃO BRASILEIRA DE NORMAS TÉCNICAS. NBR 13576: Argamassa para assentamento e revestimento de paredes e tetos - Determinação do índice de consistência. Rio de Janeiro, 2016.

ASSOCIAÇÃO BRASILEIRA DE NORMAS TÉCNICAS. NBR 13860: Glossário de termos relacionados com a segurança contra incêndio. Rio de Janeiro, 1997.

ASSOCIAÇÃO BRASILEIRA DE NORMAS TÉCNICAS. NBR 14432: Exigências de resistência ao fogo de elementos construtivos de edificações - Procedimento. Rio de Janeiro, 2001.

ASSOCIAÇÃO BRASILEIRA DE NORMAS TÉCNICAS. NBR 14323: Projeto de estruturas de aço e de estruturas mistas de aço e concreto de edifícios em situação de incêndio. Rio de Janeiro, 2013.

ASSOCIAÇÃO BRASILEIRA DE NORMAS TÉCNICAS. NBR 15200: Projeto em estruturas de concreto em situação de incêndio. Rio de Janeiro, 2012.

ASSOCIAÇÃO BRASILEIRA DE NORMAS TÉCNICAS. NBR 15270-1: Componentes cerâmicos - Blocos e tijolos para alvenaria, Parte 1: Requisitos. Rio de Janeiro, 2017.

ASSOCIAÇÃO BRASILEIRA DE NORMAS TÉCNICAS. NBR 15270-2: Componentes cerâmicos - Blocos e tijolos para alvenaria, Parte 2: Métodos de ensaio. Rio de Janeiro, 2017.

ASSOCIAÇÃO BRASILEIRA DE NORMAS TÉCNICAS. NBR 15812-1: Alvenaria estrutural - Blocos cerâmicos, Parte 1: Projetos. Rio de Janeiro, 2010.

ASSOCIAÇÃO BRASILEIRA DE NORMAS TÉCNICAS. NBR 15812-2: Alvenaria estrutural - Blocos cerâmicos, Parte 2: Execução e controle de obras. Rio de Janeiro, 2010.

ASSOCIAÇÃO BRASILEIRA DE NORMAS TÉCNICAS. NBR 15812-3: Alvenaria estrutural - Blocos cerâmicos, Parte 3: Métodos de ensaios. Rio de Janeiro, 2010.

ASSOCIAÇÃO BRASILEIRA DE NORMAS TÉCNICAS. NBR 15961-1: Alvenaria estrutural - Blocos de concreto, Parte 1: Projeto. Rio de Janeiro, 2011.

ASSOCIAÇÃO BRASILEIRA DE NORMAS TÉCNICAS. NBR 15961-2: Alvenaria estrutural - Blocos de concreto, Parte 2: Execução e controle de obras. Rio de Janeiro, 2011.

ASSOCIAÇÃO BRASILEIRA DE NORMAS TÉCNICAS. NBR 16541: Argamassa para assentamento e revestimento de paredes e tetos - Preparo da mistura para a realização dos ensaios. Rio de Janeiro, 2016. 
ASSOCIAÇÃO BRASILEIRA DE NORMAS TÉCNICAS. NBR 16605: Cimento Portland e outros materiais em pó - Determinação da massa específica. Rio de Janeiro, 2017.

ASSOCIAÇÃO BRASILEIRA DE NORMAS TÉCNICAS. NBR 16689: Gesso modificado - Métodos de ensaio. Rio de Janeiro, 2019.

ASSOCIAÇÃO BRASILEIRA DE NORMAS TÉCNICAS. NBR NM 45: Agregados Determinação da massa unitária e do volume de vazios. Rio de Janeiro, 2006.

ASSOCIAÇÃO BRASILEIRA DE NORMAS TÉCNICAS. NBR NM 52: Agregado miúdo - Determinação da massa específica e massa específica aparente. Rio de Janeiro, 2009.

ASSOCIAÇÃO BRASILEIRA DE NORMAS TÉCNICAS. NBR NM 248: Agregados Determinação da composição granulométrica. Rio de Janeiro, 2003.

AYALA, F. R. R. Mechanical Properties and Structural Behaviour of Masonry at Elevated Temperatures. 2010. 294p. Thesis (Doctor of Philosophy) - Engineering and Physical Sciences, University of Manchester, Manchester.2010

AZEVEDO, A. R. G.; FRANÇA, B. R.; ALEXANDRE, J.; MARVILA, M. T.; ZANELATO, E. B.; XAVIES, G. C. Influence of sintering temperature of a ceramic substrate in mortar adhesion for civil construction. Journal of Building Engineering, v. 19, p. 342-348. 2018.

BARBOSA, A. A.; FERRAZ, A. V.; SANTOS, G. A.; Caracterização química, mecânica e morfológica do gesso b obtido no pólo do Araripe. Cerâmica, v. 60, p. 501-508, 2014.

BRITISH STANDARDS INSTITUTION. BS 5628 - Code of practice for structural use of masonry. Part 1: Unreinforced masonry. Londres, Inglaterra. 2005.

BONITESE, K. V. Segurança contra incêndio em edifício habitacional de baixo custo estruturado em aço. 2007. 253p. Dissertação (Mestrado em Construção Civil) Universidade Federal de Minas Gerais, Belo Horizonte, 2007.

BUCHANAN, A. H.; ABU, A. K. Structural design for fire safety. John Wiley \& Sons, 2017. 436p.

CAPUZZO NETO, V. Estudo teórico e experimental da interação de paredes de alvenaria estrutural submetidas a ações verticais. 2000. 111p. Dissertação (Mestrado em Engenharia de Estruturas) - Escola de Engenharia de São Carlos, Universidade de São Paulo, São Carlos, 2000.

CARVALHO, P. R. O. Análise numérica de pequenas paredes de alvenaria estrutural de blocos de concreto em situação de incêndio: Ênfase no comportamento térmico e termoestrutural. 2019. 313p. Dissertação (Mestrado em Engenharia de Estruturas) - Escola de Engenharia de São Carlos, Universidade de São Paulo, São Carlos, São Paulo. 2019.

CERÂMICA CITY. Bloco cerâmico estrutural. Disponível em: <http://www.ceramicacity. com.br/bloco_ceramico/bloco-ceramico-estrutural/> Acesso em 03/04/2019. 2019. 
COCCO, M. Análise da ação de altas temperaturas em painéis de alvenaria estrutural de blocos cerâmicos com diferentes preenchimentos. 2014. 64 p. Monografia (Graduação em Engenharia Civil), Universidade Federal de Santa Maria, Santa Maria, 2014.

CONHECIMENTO CIENTÍFICO. Quem provocou o grande incêndio de Roma?. Disponível em: <http://conhecimentocientifico.r7.com/quem-provocou-o-grande-incendio-deroma-nao-foi-nero/> Acesso em 28/05/2019. 2018.

CORRÊA, M. R. S. Alvenaria estrutural: Interação de paredes e eficiência do grauteamento sob solicitações combinadas. Projeto de pesquisa. Programa de PósGraduação em Engenharia de Estruturas. Escola de Engenharia de São Carlos, Universidade de São Paulo. 2012.

DOLEZELOVÁ, M; SCHEINHERROVÁ, L.; KREJSOVÁ, J.; VIMMROVÁ, A.; Effects of high temperatures on gypsum-based composites. Construction and Building Materials, v. 168, p. 82-90. 2018.

DRYSDALE, D. An Introduction to Fire Dynamics. University of Edinburgh, UK. John Wiley \& Sons, LTD. 1998. 2. ed. 451 p.

DUPIM, R. H. Resistência residual de blocos, prismas e pequenas paredes de alvenaria estrutural com blocos de concreto submetidos à situação de incêndio. 2019. 228p. Dissertação (Mestrado em Engenharia de Estruturas) - Escola de Engenharia de São Carlos, Universidade de São Paulo, São Carlos, São Paulo. 2019.

DUTRA, R. P. S. Efeitos da velocidade de aquecimento nas propriedades de produtos de cerâmica estrutural. 2007. 136p. Tese (Doutorado em Ciência e Engenharia de Materiais) Centro de Ciências Exatas e da Terra, Universidade Federal do Rio Grande do Norte, Natal, 2007.

EUROPEAN COMMITTEE FOR STANDARDIZATION. Eurocode 1: Actions on structures Part 1-2: General actions - Actions on structures exposed to fire. Bruxelas 2002.

EUROPEAN COMMITTEE FOR STANDARDIZATION. Eurocode 6: EN 1996-1.1: Design of masonry structures, Part 1-1: General rules for reinforced and unreinforced masonry structures. Brussels, 2005.

EUROPEAN COMMITTEE FOR STANDARDIZATION. Eurocode 6: EN 1996-1.2: Design of masonry structures, Part 1-2: General rules: Structural fire design. Brussels, 2005.

EUROPEAN STANDARD. EN 1015, Methods of test for mortar for masonry, Part 12: Determination of adhesive strength of hardened rendering and plastering mortars on substrates, 2000.

EUROPEAN STANDARD. EN 13279: Gypsum binders and gypsum plasters, Part 2: Test methods, 2014. 
EUROPEAN STANDARD. EN 1363, Fire resistance tests, Part 2: Alternative and additional procedures, 1999.

GONÇALVES, W. P.; SILVA, V. J.; LIMA, L. K. S.; NEVES, G. A.; LIRA, H. L.; SANTANA, L. N. L. Efeitos da temperatura de queima sobre as propriedades de materiais cerâmicos. In: Congresso Brasileiro de Engenharia e Ciência dos Materiais. Natal, 2016.

GRUBBS, F. E. Procedures for detecting outlying observations in samples. Technometrics, v. 11, n. 1.1969.

HENDRY, A. W.; SINHA, B. P.; DAVIES, S. S. Design of masonry structures. London, E \& FN Spon, 2004. 279p.

HENDRY, M.; SUZUKI, M; KATO, Y. Behavior of fire-damaged mortar under variable recuring conditions. ACI Materials Journal, v. 108, n. 3. 2011.

INTERNATIONAL ASSOCIATION OF FIRE AND RESCUE SERVICES (CTIF). World fire statistics. Report n. 24, 2019.

INTERNATIONAL ORGANIZATION FOR STANDARDIZATION. ISO 834: Fire resistance tests - elements of building construction: Part 1. General requirements, 1999.

INTERNATIONAL ORGANIZATION FOR STANDARDIZATION. ISO 8421: Fire protection - Vocabulary: Part 1. General terms and phenomena of fire, 1987.

IZQUIERDO, O. S. Estudo da interface bloco/graute em elementos de alvenaria estrutural. 2015. 322p. Tese (Doutorado em Engenharia de Estruturas) - Escola de Engenharia de São Carlos, Universidade de São Paulo, São Carlos. 2015.

JB BLOCOS. Alvenaria Estrutural em pauta. Disponível em: <http://blocosdeconcreto.jblo cos.com.br/blog/alvenaria-estrutural-em-pauta/> Acesso em 03/04/2019. 2013.

JOHN, V. M; ANTUNES, R. P. N.; Argamassas de gesso. Ambiente Construído, Porto Alegre, v. 2, n. 1, p. 29-37, jan./mar. 2002.

KIMURA, E. F. A. Análise termoestrutural de pilares de aço em situação de incêndio. 2009. 212p. Dissertação (Mestrado em Engenharia de Estruturas) - Escola de Engenharia de São Carlos, Universidade de São Paulo, São Carlos, São Paulo. 2009.

KIRCHHOF, L.D. Uma contribuição ao estudo de vigas mistas aço-concreto simplesmente apoiadas em temperatura ambiente e em situação de incêndio. 2004. 142p. Dissertação (Mestrado em Engenharia de Estruturas) - Escola de Engenharia de São Carlos, Universidade de São Paulo, São Carlos, 2004.

KREJSOVÁ, J.; DOLEZELOVÁ, M; PERNICOVÁ, R.; SVORA, P.; VIMMROVÁ, A.; The influence of different aggregates on the behavior and properties of gypsum mortars. Cement and Concrete Composites, v. 92, p. 188-197. 2018.

LEITE, H. A. L. Alvenaria estrutural em situação de incêndio - proposta de avaliação com vistas à normatização. 2018. 152p. Dissertação (Mestrado em Engenharia Civil) - 
Faculdade de Engenharia Civil, Arquitetura e Urbanismo, Universidade Estadual de Campinas, Campinas, 2018.

LEITE, H. A. L.; MORENO JÚNIOR, A. L.; TORRES, D. L. Dimensionamento da alvenaria estrutural em situação de incêndio: contribuição à futura normatização nacional. Ambiente Construído, Porto Alegre, v. 16, n. 2, p. 89-107, abr./jun. 2016.

LIMA, R. C. A; RIGÃO, A. O.; MOHAMAD, G.; KIRCHHOF, L. D.; SANTOS NETO, A. B. S.; Assess of hollow clay block masonry wallets under high temperature. Revista Matéria, v. 23, n. 03, 2018.

LOPES, R. F. R.; RODRIGUES, J. P. C.; PEREIRA, J. M.; LOURENÇO, P. B. Avaliação experimental de uma parede de alvenaria estrutural de blocos de concreto de três células em situação de incêndio. Concreto \& Construções, ed. 90, 86-94, 2018.

MANDIC, V.; TKALCEC, E.; POPOVIC, J.; KURAJICA, S.; SCHMAUCH, J. Crystallization pathway of sol-gel derived zinc-doped mullite precursors. Journal of the European Ceramic Society v. 36, n. 5, p. 1285-1292. 2016.

MARVILA, M. T.; AZEVEDO, A. R. G.; ALEXANDRE, J.; ZANELATO, E. B.; AZEREDO, N. G.; SIMONASSI, N. T.; MONTEIRO, S. N. Correlation between the properties of structural clay blocks obtained by destructive tests and ultrassonic pulse tests. Journal of Building Engineering, v. 26.. 2019.

MATA, R. C., Análise experimental e numérica do comportamento de junta em painéis de contraventamento de alvenaria estrutural. 2011. 184p. Tese (Doutorado em Engenharia de Estruturas) - Escola de Engenharia de São Carlos, Universidade de São Paulo. 2011.

MEHTA, P. K.; MONTEIRO, P. J. M. Concreto: Microestrutura, propriedades e Materiais. Ibracon, 2014. 751p.

MENDES, R. J. K. Resistência à compressão de alvenarias de blocos cerâmicos estruturais. 1998. 185p. Dissertação (Mestrado em Engenharia Civil) - Universidade Federal de Santa Catarina, Florianópolis, 1998.

MENEGON, J.; REGINATO, L. A.; LORENZI, A.; GRAEFF, A. G.; SILVA FILHO, L. C. P. Alvenaria estrutural sob ação de altas temperaturas: Comparação de diferentes blocos através de termografia infravermelha. $4^{\circ}$ Congresso Ibero-Latino-Americano sobre Segurança contra Incêndio. Recife - PE, Brasil, 7p. 2017.

MOHAMAD, G. Comportamento mecânico na ruptura de prismas de blocos de concreto. 1998. 178p. Dissertação (Mestrado em Engenharia Civil) - Universidade Federal de Santa Catarina, Florianópolis, 1998.

MOHAMAD, G. Mecanismos de ruptura das alvenarias de blocos de concreto. 2007. 310p. Tese (Doutorado em Engenharia Civil/Estruturas) - Universidade do Minho, Guimarães, 2007.

NADJAI, A.; O'GARRA, M.; ALI, F.; JURGEN, R. Compartment masonry walls in fire situations. Fire Technology, v. 42, 211-231, 2006. 
NGUYEN, T. D.; MEFTAH, F. Behavior of clay hollow-brick masonry walls during fire. Part 1: Experimental analysis. Fire Safety Journal, v. 52, 55-64, 2012.

NGUYEN, T. D.; MEFTAH, F. Behavior of hollow clay brick masonry walls during fire. Part 2: 3D finite element modelling and spalling assessment. Fire Safety Journal, v. 66, 35-45, 2014.

NUNES, J. M. B. Uma abordagem numérica e analítica para determinação da temperatura e do momento fletor crítico em vigas de aço em situação de incêndio. 2005. 186p. Tese (Doutorado em estruturas e Construção Civil), Universidade de Brasília, Brasília, 2005.

OLIVEIRA, L. M. F. Estudo teórico e experimental do comportamento das interfaces verticais de paredes interconectadas de alvenaria estrutural. 2014. 272p. Tese (Doutorado em Engenharia de Estruturas) - Escola de Engenharia de São Carlos, Universidade de São Paulo, São Carlos, 2014.

PARSEKIAN, G. A.; HAMID, A. A.; DRYSDALE, R. G. Comportamento e dimensionamento de alvenaria estrutural. São Carlos, Edufscar, 2014. 625p.

PINTEREST. Acervo pessoal de Neto Adas. Disponível em: <http://br.pinterest.com/pin/561 331541041326821/> Acesso em 30/05/2019. 1972.

POLÍCIA MILITAR DO ESTADO DE SÃO PAULO - CORPO DE BOMBEIROS. Instrução Técnica No 08/2018 - Segurança estrutural contra incêndio. São Paulo, 2018.

RAMALHO, M. A.; CORREAA, M. R. S. Projeto de edifícios de alvenaria estrutural. São Paulo, Pini, 2003. 174p.

REGOBELLO, R. Análise numérica de seções transversais e de elementos estruturais de aço e mistos de aço concreto em situação de incêndio. 2007. 269 p. Dissertação (Mestrado em Engenharia de Estruturas) - Escola de Engenharia de São Carlos, Universidade de São Paulo, São Carlos, 2007.

RIGÃO, A. O. Comportamento de Pequenas Paredes de Alvenaria Estrutural Frente a Altas Temperaturas. Santa Maria, 2012. 142 p. Dissertação (Mestrado em Engenharia Civil) - Escola de Engenharia, Universidade Federal de Santa Maria, São Maria, 2012.

RIZZATTI, E; ROMAN, H. R.; MOHAMAD, G.; NAKANISHI, E. Y.; Mechanical behavior analysis of small-scale modeling of ceramic block masonry structures - Geometries effect. Revista Ibracon de Estruturas e Materiais, v. 5, n. 5, p. 702-736. 2012.

RODOVALHO, F. S. Simulação numérica de blocos e prismas de alvenaria em situação de incêndio. 2018. 166p. Dissertação (Mestrado em Engenharia de Estruturas) - Escola de Engenharia de São Carlos, Universidade de São Paulo, São Carlos, 2018.

ROSEMANN, F. Resistência ao fogo de paredes de alvenaria estrutural de blocos cerâmicos pelo critério de isolamento térmico. 2011. 160 p. Dissertação (Mestrado em Engenharia Civil). Universidade Federal de Santa Catarina, Florianópolis, 2011. 
RUSSO, S.; SCIARRETTA, F. Numerical study on the residual mechanical performance of traditional brickwork after standard fire exposure. International Conference on Structural Analysis of Historical Constructions. México City, México, 12 p. 2014.

SEITO, A. I. et al. A segurança contra incêndios no Brasil. São Paulo: Projeto Editora, 2008. 484 p.

SILVA, A. G. P; ALVES Jr., C. A sinterização rápida: sua aplicação, análise e relação com as técnicas inovadoras de sinterização. Cerâmica, v. 44, n. 290, 1998.

SILVA, V. P. Considerações sobre as normas brasileiras de estruturas em situação de incêndio. Revista Incêndio. São Paulo, p. 52-57, 2007.

SILVA, V. P. Sobre o coeficiente $\boldsymbol{\gamma} \boldsymbol{s}$ do método do tempo equivalente para a determinação do tempo requerido de resistência ao fogo das estruturas. Revista Minerva, vol 5, nº 3, p. 315321, 2008.

SILVA, V. P. Projeto de estruturas de concreto em situação de incêndio. São Paulo, Blucher, 2012. 237p.

SOARES, M. M. M. Especificação, execução e controle de alvenaria estrutural em blocos cerâmicos de acordo com a NBR 15812. 2011. 187p. Dissertação (Mestrado em Estruturas e Construção Civil), Universidade Federal de São Carlos, São Carlos, 2011.

SOUZA, R. P. Avaliação da influência da espessura do revestimento argamassado e do carregamento no comportamento da alvenaria frente a altas temperaturas. 2017. 133p. Dissertação (Mestrado em Engenharia Civil), Universidade do Vale do Rio dos Sinos, São Leopoldo, 2017.

UOL. Sobrevivente comemora 40 anos de vida após incêndio no edifício Joelma. Disponível em: <http:// noticias.uol.com.br/cotidiano/ultimasnoticias/2014/02/01/sobreviven te-comemora-40-anos-de-vida-apos-incendio-no-edificio-joelma/> Acesso em 30/05/2019. 2014.

VILLAR, C. E. F. Caracterização e comportamento da alvenaria estrutural de blocos cerâmicos. 2005. 107p. Dissertação (Mestrado em Engenharia e Ciência de Materiais) Centro de Tecnologia, Universidade Federal do Ceará, Fortaleza, Ceará. 2005.

YAO, W; LIU, H.; XU, Y.; XIA, K.; ZHU, J.; Thermal degradation of dynamic compressive strength for two mortars. Construction and Building Materials, v. 136, p. 139-152. 2017.

ZEGARRA, R. R. C. Comportamento de argamassas industrializadas de assentamento submetidas a altas temperaturas. 2018. 92p. Dissertação (Mestrado em Engenharia Civil), Universidade Federal de Santa Maria, Santa Maria, 2018. 


\section{APÊNDICE A - DESCRIÇÃO DO TESTE ESTATÍSTICO DE GRUBBS}

Este teste foi desenvolvido por Grubbs (1969) com o objetivo de verificar a presença de valores discrepantes em amostras em que os dados seguem um padrão de distribuição normal. A presença desses valores pode ser justificada devido às manifestações de variabilidade aleatória dos dados ou possíveis erros durante a aquisição e tratamento dos mesmos.

De modo geral, a verificação quanto à existência de valores espúrios é realizada mediante o cálculo estatístico, cujos resultados são comparados com valores críticos baseados na teoria de amostras aleatórias. Ao final da verificação, identificando-se um valor considerado discrepante, este é retirado da amostra, calcula-se uma nova média e desviopadrão para o espaço amostral atualizado, e realiza-se um novo teste até que todos os valores sejam considerados aceitáveis.

No teste de Grubbs, dado um conjunto de dados $X_{i}$ com $i=1,2,3 \ldots$, utiliza-se o seguinte teste estatístico:

$$
Z=\frac{\left|x_{i}-\delta\right|}{s}
$$

Equação A.1

Onde:

$\mathrm{X}_{\mathrm{i}}$ é uma amostra do conjunto $\mathrm{X}_{\mathrm{i}}$;

$\delta$ é a média amostral do conjunto $\mathrm{X}_{\mathrm{i}}$;

s é o desvio-padrão do conjunto $\mathrm{X}_{\mathrm{i}}$.

Se $\mathrm{Z}$ for maior que $\mathrm{Z}_{\mathrm{c}}$ (valor crítico tabelado), para um nível de significância $\alpha$, adotado neste trabalho igual a 5\%, considera-se aceita a hipótese de que a amostra é discrepante e a mesma é retirada do conjunto de dados. A Tabela A.1 apresenta os valores de $\mathrm{Z}_{\mathrm{c}}$ para um nível de significância de $5 \%$ conforme o tamanho do conjunto.

Tabela A.1 - Valores críticos para o teste de Grubbs

\begin{tabular}{cc|cc|cc}
\hline \hline $\mathbf{n}$ & $\mathbf{Z}_{\mathbf{c}}$ & $\mathbf{n}$ & $\mathbf{Z}_{\mathbf{c}}$ & $\mathbf{n}$ & $\mathbf{Z}_{\mathbf{c}}$ \\
\hline \hline 3 & 1,153 & 9 & 2,110 & 15 & 2,409 \\
4 & 1,462 & 10 & 2,176 & 16 & 2,443 \\
5 & 1,671 & 11 & 2,234 & 17 & 2,475 \\
6 & 1,822 & 12 & 2,285 & 18 & 2,504 \\
7 & 1,938 & 13 & 2,331 & 19 & 2,531 \\
8 & 2,032 & 14 & 2,372 & 20 & 2,557 \\
\hline \hline
\end{tabular}

Fonte: Adaptada de Grubbs (1969). 


\section{APÊNDICE B - DESCRIÇÃO DOS TESTES ESTATÍSTICOS F E T}

Com o objetivo de realizar uma comparação entre os diferentes resultados dos ensaios experimentais, realizaram-se os testes estatísticos $\mathrm{F}$ e T para a significância estatística entre os resultados distintos.

Neste trabalho, para análise da homogeneidade da variância entre duas amostras utilizou-se o teste estatístico F, com o objetivo de verificar se a variância entre as duas amostras divergiam estatisticamente, e para verificar a divergência entre as médias das amostras foi realizado o teste $\mathrm{T}$ ou "t de student". Ambos os testes foram realizados de maneira automatizada com auxílio do Excel adotando-se um nível de significância igual a 5\%, ou seja, $\alpha=0,05$.

Inicialmente, realizou-se o teste F para verificar a variância entre as duas amostras. De modo geral, o resultado obtido no teste $\mathrm{F}$ representa um valor adquirido da distribuição $\mathrm{F}$ de probabilidades, sendo este o valor observado para as respectivas amostras $\left(\mathrm{F}_{\mathrm{o}}\right)$. A avaliação quanto à divergência entre as variâncias é realizada comparando o valor observado $\left(\mathrm{F}_{\mathrm{o}}\right)$ com o valor crítico $\left(\mathrm{F}_{\mathrm{c}}\right)$, correspondente ao nível de significância adotado $(\alpha)$.

Assim, $\mathrm{Se} \mathrm{F}_{\mathrm{o}}>\alpha$ considera-se aceita a hipótese de que não há divergência significativa entre a variância das amostras.

Posteriormente, realizou-se o teste $\mathrm{T}$ para verificar se haviam divergências significativas entre as médias de duas amostras. De maneira similar ao realizado anteriormente, o resultado obtido do teste $\mathrm{T}$ é denominado valor $\mathrm{p}$, que por sua vez é comparado com o nível se significância $\alpha$ para verificação da hipótese de igualdade entre as médias das amostras.

Assim, se valor $\mathrm{p}<\alpha$ considera-se aceita a hipótese de que há divergências significativas entre as médias das amostras, ou seja, quanto menor o valor $\mathrm{p}$, maior a diferença estatística entre as médias das amostras. 